

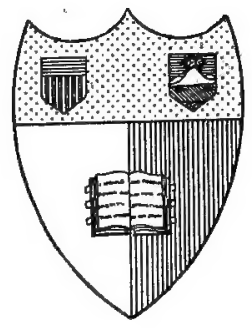

\section{ANew 琞ark \\ State Orollege af Aariculture}

At Ofarnell Utninersity

3thara, ㅊ. ㅈ.

\section{Tithrary}




\section{Cornell University Library}

The original of this book is in the Cornell University Library.

There are no known copyright restrictions in the United States on the use of the text.

http://www.archive.org/details/cu31924003079849 


$$
\begin{array}{r}
@ \\
S F 523 \\
N 397 \\
1878
\end{array}
$$




\section{OPINIONS OF THE PRESS.}

From The Journal of Horticulture, February 28, 1865.

Mr. Neighbour says in his preface : “We are so frequently applied to for advice on matters connected with bees and bee-hives, that it seemed likely to prove a great advantage to our correspondents and ourselves if we could point to a "handy book ' of our own which should contrin full and detailed replies sufficient to meet all ordinary inquiries." Keeping this object steadily in view, the writer describes the various hives and apiarian apparatus manufactured by his firm, pointing out the various advantages claimed for them, and giving ample directions for their use. When we add that the author expresses his acknowledgments to $\mathrm{Mr}$, Woodlbury, Mr. Taylor, the illustrious Huber and $\mathrm{Mr}$. Langstroth, it may readily be imagined that the information derived from such sources must in the main be correct, and that Mr. Neighbour, in addition to the strictly business portion of his work, has been enabled to impart to his readers a very considerable amount of sound instruction on most points of Apiarian management.

From The Journal of Horticulture, May 29, I866.

Mrr. Neighbour's book, the first edition of which was noticed by us in February 1865, now makes its appearance in a new guise, being reduced from demy 8 vo. to crown $8 \mathrm{vo}$., whilst the number of its pages is increased from $\mathbf{1} 34$ to $\mathbf{2 7 4}$, with but a slight increase in price. In addition to a description of the various hives and apiarian apparatus sold by the well-known firm of which the author is a member, it contains a considerable amount of generally accurate information compiled from the best authorities; Mr. Woodbury's contributions to our pages being in particular heavily drawn upon.

A new feature in this edition is a couple of steel plates illustrative of the anatomy of the bee, engraved-by Mr. E. W. Robinson with his customary ability; embracing also coloured delineations of the three sexes of the Ligurian or Italian variety of honey-bee. . . .

Mr. Neighbour possesses a very great advantage over a mere compiler, in that he himself is a practical bee-keeper, and divers 


\section{OPINIONS OF THE PRESS-(CONTINUED).}

anecdotes of his experiences are related by him in a light and amusing manner. For this reason also the information conveyed in his pages is, as we have already stated, very generally correct.

\section{Athenfeum, August 19, 1865.}

Emanating from a house so well known and so extensively patronized by the cultivators of bees, it will readily be concluded that the object of the present work is primarily commercial. The author, a member of the firm, in giving the reason for the publication of his hook, speaks in the name of the company. "We are," he says, "so frequently applied to for advice on matters connected with bees and bee-hives, that it seemed likely to prove a great advantage, alike to our correspondents and ourselves, if we could point to a 'handy-book' of our own, which should contain full and detailed replies sufficient to meet all reasonable inquiries." This is candid and open, and stands in favourable contrast to the ordinary puffing books which aim to conceal under the aspect often of a scientific treatise the boasting advertisement of their own wares. It is but justice to the respectable house from which the present little treatise issues to say that it fulfils its public object, presenting one of the most useful practical treatises on this most interesting pursuit which we have met with. It does not profess to enter deeply into the physiological marvels of the habits of bees; it is, in fact, meagre in the scientific phase of the subject. The various theories concerning the propagation of bees are nowhere discussed, ${ }^{*}$ and the hypothesis of Siebold is not even alluded to.* But for those persons who desire to know how to procure good honey with certainty, and how to watch in safety the working of these little untaught but unerring mathematicians, the work of Mr. Neighbour will be found very useful. It also informs us where the best hives of every kind and form are to be obtained-of course, of "Messis. Neighbour \& Sons."

\section{The Reader, 26 August, I865.}

The Apiary; or, Bees, Beehives, and Bee Culture. By Alfred Neighbour. (Kent \& Co.)

This valuable manual is, what it professes to be, a familiar account of the habits of bees, and the most improved methods of management, with full directions adapted for the cottager, farmer, or scientific apiarian. The writer is a regular enthusiast, but an enthusiast whose practical knowledge of the subject is made all the more available to the reader from the very enthusiasm which, as in Virgil, leaves not the most minute instruction untold. Nobody can write about bees without quoting poetry, and Mr. Neighbour does this largely, yet most aptly.

* Will be found in third edition. 
THE APIARY. 




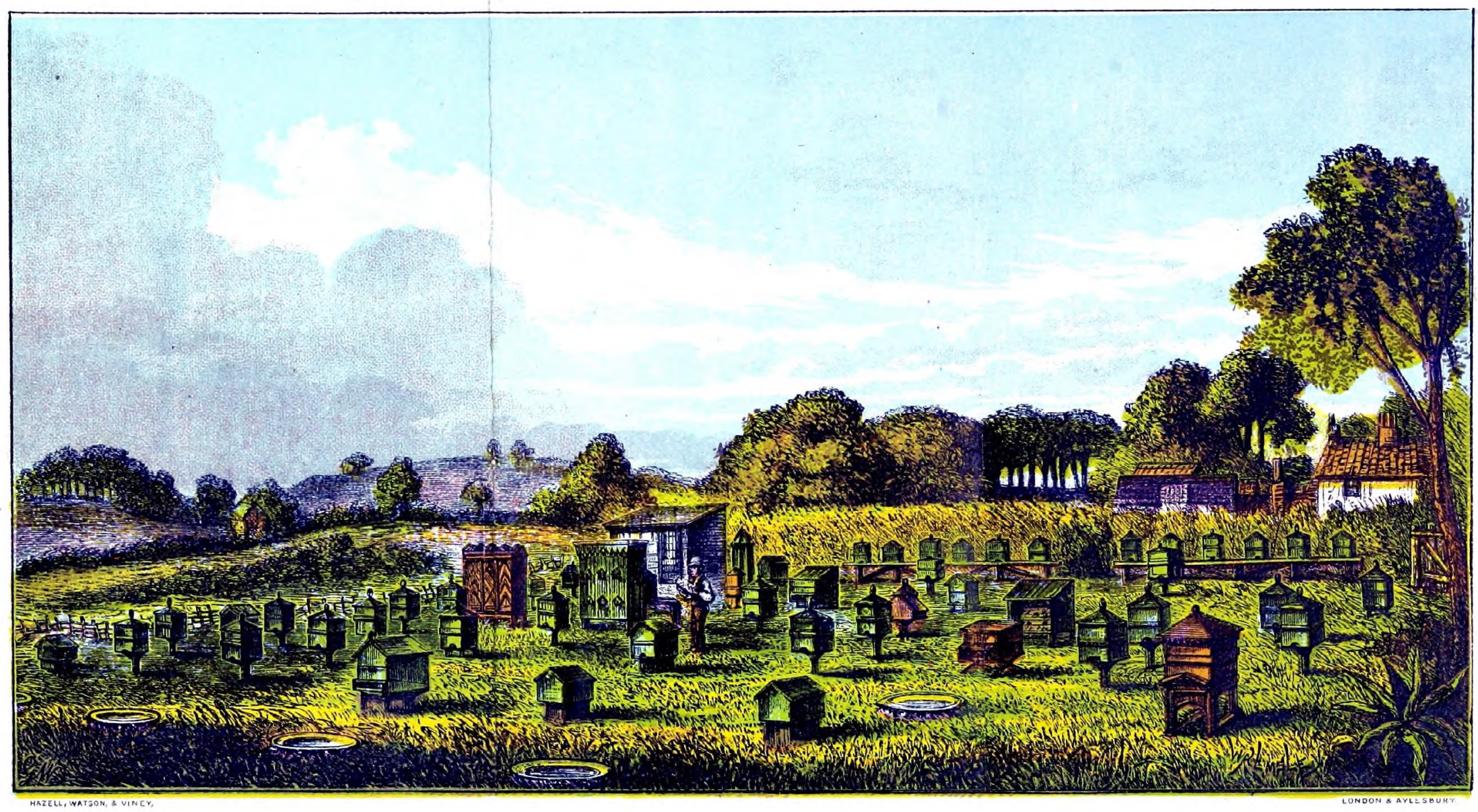

GEO. NEIGHBOUR \& SONS' BEE FARM, WEST END, HAMPSTEAD.-See page 330 



\title{
THE APIARY;
}

OR,

\section{BEES, BEEHIVES, AND BEE CULTURE.}

BEING A FAMILIAR ACCOUNT OF THE HABITS OF BEES AND THE MOST IMPROVED METHODS OF MANAGEMENT.

BY

ALFRED NEIGHBOUR.

\author{
THIRD EDITION. \\ GREATLY ENLARGED, REVISED, AND REMUDELLED.
}

"Beaucoup de gens aiment les abeilles : je n'ai vu personne qui les aima médiocrement: on se passionne pour elles."-GeliEu.

\section{LONDON :}

KENT AND CO., PATERNOSTER ROW;

GEO. NEIGHBOUR AND SONS,

I49, REGENT STREET, AND I27, HIGH HOLBORN, AND ALL BOOTSELLERS.

э 878. 


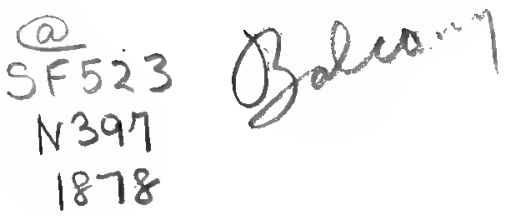

(a) 41198

Hazell, Watson, and Viney, Printers, London and Aylesbury. 


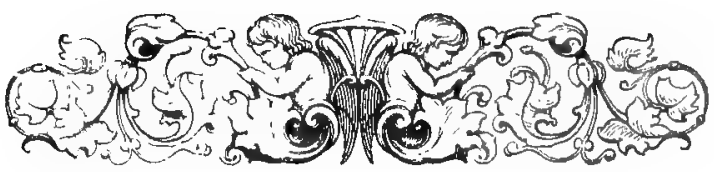

PREFACE TO THE THIRD EDITION.

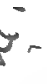
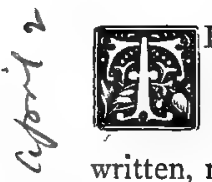

HE present issue of our handbook may be fairly said to be really a new work. Not that the greater portion of it has been consecutively rewritten, nor yet that the larger half of the former matter

() has wholly disappeared; but the additions of entirely new \& sections and half-sections, the transpositions with a view to facilitating reference, the erasures of what is either out of date or only repetition-in short, the thorough over-

$m$ hauling of the text from beginning to end-are such as i to render the form in which it is now presented a new 4. book rather than an ordinary fresh edition.

First as to our own department, the practical appliances. it: The descriptions of several'hives and apparatus that have gone out of use have been removed to make room for the much larger number of new and improved inventions. 5 Of the eighteen hives now described, no less than a half are new introductions, and the same is the case in greater 
or less degree with the supers, the covers, and the bee contrivances of every kind.

The chapter on "Manipulation" has been equally enlarged, having throughout been collated with the chapters on that branch in Mr. Iangstroth's "Honey Bee." For very many valuable additions, both large and small, we are therefore indebted to that source, and we have also some obligations to acknowledge to $\mathrm{Mr}$. Cheshire's " Practical Bee-keeping."

It is in reference chiefly to this department that so many transpositions have been made from the arrangement of the matter in former editions. Finding that by giving extensive practical directions under nearly every individual hive we were losing much greatly needed space by repetition, and at the same time giving less complete instructions to each, we have endeavoured when possible to comprise all this in articles of a general character, and to retain under special hives or appliances such only as was strictly peculiar to themselves. The system of references now carried out, together with the numbering of sections and displaying the numbers in the head-lines of every page, will we trust remove even that small apparent inconvenience which is the accompaniment of a large and substantial gain.

Rut perhaps more than all has the earlier part of our work been enlarged and emended-that which treats on the insect itself, its natural history, its reproductive economy, its habits, and its structure. For this course 
of improvement we are largely indebted to the very masterly and exhaustive treatise of Baron von Berlepsch, "Die Biene und ihre Zucht in beweglichen Waben" ("The Bee and its Culture in Movable Combs"); after this to Dr. Dzierzon's latest work, "Rationelle Bienenzucht;" to Schmid and Kleine's "Leitfaden;" to Samuelson and Hicks's "Honey Bee;" to Mr. John Hunter's very comprehensive and readable "Manual of Bee-keeping;" and to the British and American Bet Fournals, the former for letters from correspondents, and the latter also for the very able articles by which that remarkably well-conducted periodical is distinguished. To Mr. Frederick Smith, of the Entomological Department at the British Museum, we have also to acknowledge our indebtedness for courteous personal communications rendered more than once.

Reference should also be made to aid in the translations from the German Treatises before mentioned, as well as to some other literary assistance which we hope has added to the interest of this work.

149, REgent StREeT, LonDON, August 1877 . 



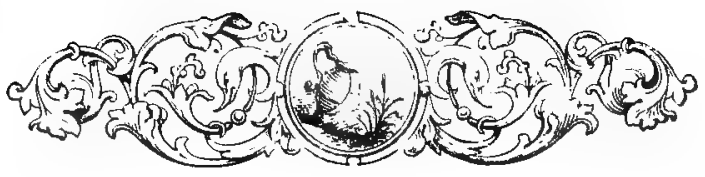

\section{PREFACE TO THE FIRST EDITION.}

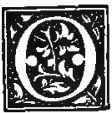

UR apology for preparing a bee-book is a very simple one. We are so frequently applied to for advice on matters connected with bees and beehives, that it seemed likely to prove a great advantage, alike to our correspondents and ourselves, if we could point to a "handy book" of our own which should contain full and detailed replies sufficient to meet all ordinary enquiries. Most of the apiarian manuals possess some special excellence or other, and we have no wish to disparage any of them; yet in all we have found a want of explanations relating to several of the more recent improvements.

It has more especially been our aim to give explicit and detailed directions on most subjects connected with the hiving and removing of bees, and also to show how, by judicious application of the "depriving" system, the productive powers of the bees may be enormously increased. 
We need say little here as to the interest that attaches to the apiary as a source of perennial pleasure for the amateur naturalist. Many of the hives and methods of management are described with a direct reference to this class of bee-keepers, so that, besides plain and simple directions suitable for cottagers with their ordinary hives, this work will be found to include instructions useful for the scientific apiarian, or at least valuable for those who desire to gain a much wider acquaintance with the secrets of bee-keeping than is now usually possessed. We would lay stress on the term "acquaintance," for there is nothing in the management of the various bar-and-frame hives which is at all difficult when frequent practice has rendered the bee-keeper familiar with them. Such explicit directions are herein given as to how the right operations may be performed at the right times, that a novice may at once commence to use the modern hives. The word "new-fangled" has done good service for the indolent and prejudiced, but we trust that our readers will be of a very different class. Let them give a fair trial to the modern appliances for the humane and depriving system of bee-keeping, and they will find offered to them an entirely new field of interest and observation. At present our continental neighbours far surpass us as bee-masters; but we trust that the following season, if the summer be fine, will prove a turning point in the course of English beekeeping. There is little doubt that a greater number of 


\section{PREFACE TO THE FIRST EDITION. xi}

intelligent and influential persons in this country will become bee-keepers than has ever been the case before.

Our task would have lost half its interest did we not hope that it would result in something beyond the encouragement of a refined and interesting amusement for the leisurely classes. The social importance of beekeeping, as a source of pecuniary profit for small farmers and agricultural labourers, has never been appreciated as it deserves. Yet these persons will not, of themselves, lay aside the bungling and wasteful plan of destroying the bees, or learn without being taught the only proper method, that of deprivation. Their edu. cated neighbours, when once interested in the pursuit, will be the persons to introduce the more profitable system of humane bee-keeping. The clergy especially, as permanent residents in the country, may have great influence in this respect. There is not a rural or suburban parish in the kingdom in which bee-keeping might not be largely extended, and the well-being of all but the very poorest inhabitants would be greatly promoted. Not only would the general practice of beekeeping add largely to the national resources, but that addition would chiefly fall to the share of those classes to whom it would be of most value. Moreover, in the course of thus adding to their income, the uneducated classes would become interested in an elevating and instructive pursuit.

It is curious to observe that honey, whether regarded 


\section{xii

as a manufactured article or as an agricultural product, is obtained under economical conditions of exceptional advantage. If regarded as a manufactured article, we notice that there is no outlay required for "labour," nor any expense for "raw material." The industrious labourers are eager to utilise all their strength; they never "combine" except for the benefit of their master, they never "strike" for wages, and they provide their own subsistence. All that the master-manufacturer of honey has to do financially is, to make a little outlay for "fixed capital" in the needful "plant" of hives and utensils; no "floating capital" is needed. Then, on the other hand, if we regard honey as an agricultural product, it presents as such a still more striking contrast to the economists' theory of what are the "requisites of production." Not only is there no outlay needed for wages, and none for raw material, but there is nothing to be paid for "use of a natural agent." Every square yard of land in the United Kingdom may come to be cultivated, as in China, but no proprietor will ever be able to claim "rent" for those "waste products" of the flowers and leaves which none but the winged workers of the hive can ever utilise.

The recent domestication in England of the Ligurian or Italian Alp bee adds a new and additional source of interest to bee-culture. We have therefore gone pretty fully into this part of the subject; and believe that what is here published with regard to their intro- 


\section{PREFACE TO THE FIRST EDIIYON. xiii}

duction embodies the most recent and reliable information respecting them that is possessed by English apiarians.*

We are under many obligations for the advice and assistance that we have on many occasions received from Mr. T. W. Woodbury, of Exeter, whose apiarian skill is unrivalled in this country. Our acknowledgments are also due to Mr. Henry Taylor, author of an excellent "Bee-keeper's Manual," for his help and counsel during the earlier years of our apiarian experience. Both these gentlemen have frequently communicated to us their contrivances and suggestions, without thought of fee or reward for them. In common with most recent writers on bee-culture, we are necessarily largely indebted to the standard works of Huber and succeeding apiarians. From the more recent volume of the Rev. L. L. Langstroth we have also obtained useful information. But having ourselves, of later years, had considerable experience in the manipulation and practical managemennt of bees, we are enabled to confirm or qualify the statements of others, as well as to summarise information gleaned from various sources.

* Some of our apiarian friends may be inclined to be discouraged from cultivating the Ligurian bees in consequence of the liability of their becoming hybridised when located in proximity to the black bees. We can dispel these fears by stating that we have not unfrequently found that hybrid queens possess the surprising fecundity of the genuine Italian ones, whilst the English stocks in course of time hecome strengthened by the infusion of foreign blood. 
Let it be understood that we have no patented devices to push; we are free to choose out of the many apiarian contrivances that have been offered of late years, and we feel perfectly at liberty to praise or blame as our experience warrants us in doing. It does not follow that we necessarily disparage hives which are not described herein; we have sought as much as possible to indicate the principles on which good hizes must be constructed, whatever their outward size or shape. All through the work, we have endeavoured to adopt the golden rule of "submission to Nature" by reference to which all the fancied difficulties of bee-keeping may be easily overcome. In none of the attempts of men to hold sway over natural objects is the truth of Bacon's leading doctrine more beautifully illustrated than in the power that the apiarian exercises in the little world of bees.

Some persons may consider we have used too many poetical quotations in a book dealing wholly with matters of fact. We trust, however, that the examination of the extracts will at once remove that feeling of objection.

We venture to hope that the following pages contain many valuable hints and interesting statements which may tend to excite increased and renewed attention to the most useful and industrious of all insects.

Although bees have neither reason nor religion for their guide, yet from them man may learn many a 
lesson of virtue and industry, and may even draw from them thoughts suggestive of trust and faith in God.

We beg leave to conclude our preface, and introduce the subject, by the following extract from Shakespeare, who, without doubt, kept bees in that garden at Stratford wherein he used to meditate :-

"So work the honey-bees;

Creatures that, by a rule in Nature, teach

The art of order to a peopled kingdom.

They have a king and officers of sorts;

Where some, like magistrates, correct at home;

Others, like merchants, venture trade abroad;

Others, like soldiers, armèd in their stings,

Make boot upon the summer's velvet buds ;

Which pillage they, with merry march, bring home

To the tent royal of their emperor:

Who, busied in his majesty, surveys

The singing masons building roofs of gold ;

The civil citizens kneading up the honey;

The poor mechanic porters crowding in

Their heavy burdens at his narrow gate ;

The sad-eyed justice, with his surly hum,

Delivering o'er to executors pale

The lazy, yawning drone."

Shakespeare's Henry $V$, Act I. Scene 2. 


$$
\text { . }
$$




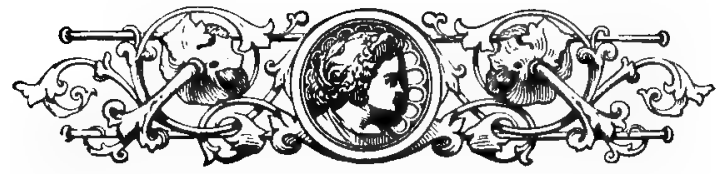

\section{O N T ENTS.}

INTRODUCITON.

Literature OF BEE-KUEPING

CHAPTER I.

The BeE as an INSECT.

SEC.

I. Classification $• \quad \cdot \quad \cdot \quad 7$

II. The Queen . . . . . 8

III. The Drone . * * . I9

IV. The Worker . . . . $\quad 27$

V. The Italian or Ligurian Bee . • . 34

VI. Other Foreign Varieties . . . . . . 45

VII. Faculties and Functions . . . 54

VIII. Eggs and Transformations . 59

IX. Reproductive Economy . . . . 62

X. Relation of Sex to Cells . . . . 67

XI. The Rationale of Swarming . . . $\quad 7^{2}$

XII. Increase of Bees • $\quad . \quad$. $\quad . \quad .82$

CHAPTER II.

Anatomy and Physiology.

I. Preliminary Remarks . $\quad . \quad$. $\quad . \quad 86$

II. The Head and Organs of Sensation - $\quad$ - 88 
III. The Thorax and Organs of Motion

CHAPTER IIT.

MOder B BehITES.

I. Common Cottager's Hive

II. Neighbours' Crystal Palace Skep

. 108

III. The Cottager's Hive .

. 109

IV. An Improver Cottager's Hive.

. 110

V. Neighbours' Improved Cottager' Hive

. I12

VI. 'The Ladies' Observatory' Hive.

. II 3

VII. Nutt's Collateral Hive

. 120

VIII. Huber's Hive .

. 123

. 127

IX. The Woodbury Frame Hive .

. 134

X. Neighbours' New Frame Hive

. 139

XI. Neighbours' Cottager's Frame IIive

. 142

XII. The Philadelphia Frame Hive

- I43

XIII. Cheshire's Frame Hive

- 145

XIV. Abbott's New Frame Hive

. 146

XV. The Stewarton Hive .

. 146

XVI. The Lanarkshire Hive .

. 155

XVII. Neighbours' Unicomb Observatory Hive-Outdoor

. 157 XVIII. Neighbonrs' Unicomb Observatory Hive-Indoor

. 162

CHAPTER IV:

Fittings and Apparatis.

I. Bee-Houses .

. $\mathbf{1} 66$

II. Zinc Covers

. 171

III. Wood Covers .

. 172

IV. Quilts .

. 180

V. Iiell Glasses

VI. Bar Supers

VII. Ekes and Nadirs

. 180

. 183

. 186 
SEC.

VIII. Impressed Wax Sheets

. 187

IX. Comb Foundations

X. Cheshire's Guide-Maker

. 190

XI. Bar-Frame Holder

. 191

XII. Cheshire's Transferring Board.

XIII. Honey Cutters

- 192

- 192

. 193

XIV. The Honey Extractor .

. 193

XV. Cheshire's Nucleus Hive

. 197

XVI. Queen-Cages .

XVII. Queen and Drone Preventer

XVIII. Bee-Traps

XrX. Drone-Traps

XX. Bee-Feeders

XXI. Fumigators

XXII. Bee-Dress or Protector

. 198

. 200

. 201

. $20 \mathrm{I}$

. 202

. 206

. 208

CHAPTER $V$.

BeE Manipulation.

I. Hiving Swarms

- 212

II. Transferring Swarms .

III. Transferring Old Stocks

IV. Driving

V. Uniting Colonies

VI. Artificial Swarming

VII. Queen-Rearing

VIII. Introducing New Queens

IX. Italianising

$\mathrm{X}$. General Hints on Frame Hives

XI. Removing Bees

XII. Supplying Natural Comb

XIII. Applying Supers

XIV. Removing Supers

XV. Removing Frames

. 218

. 222

. 226

. 229

. 233

. 243

. 247

. $25 \mathrm{I}$

. 254

. 259

. $26 \mathrm{I}$

. 264

. 266

. 268 
SEC.

XVI, Extracting Honey

XVII. Melting Combs down

.275

XVIII. Weighing Hives

.276

XIX. Feeding

. 279

XX. Winter Precautions

. 283

\section{CHAPTER VI.}

Miscellaneous Information.

I. Stings: their Prevention and Cure .

II. Position of Hives

III. Pasturage for Bees

V. Pollen, or Bee-Bread .

. 298

VI. Propolis, or Bees' Cement

. 300

VII. Secretion of Wax

. 302

VIII. Robbing

IX. Diseases of Bees

- 305

- 306

$\mathrm{X}$. Bee Enemies .

IX. Bee-keeping in Londun

XII. General Remarks

APPENDIX.

International Exhibition of 1862

Cases of Acclimatising Bees

- 349

Philadelphia Exhibition

- 350

Caledonian Apiarian Society

- 354 


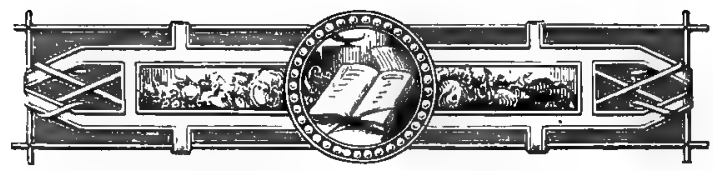

DESCRIPTION OF PLATES.

\section{PLATE I. (PAge 34).}

I. Queen bee.

1a. Antenna of ditto.

I $b$. Hind leg of ditto.

Ic. Front view of head of ditto.

1 $t$. Mandible of ditto.

2. Worker, or imperfect female.

2a. Antenna of ditto.

2b. Hind leg of ditto, inner side showing the pollen-brushes.

2b* Ditto, outer side showing the pollen-basket.

$2 c^{*}$ Side view of head.

2c. Back view of ditto, showing the junction of the gullet with the thorax, and position of the tongue and its appendages.

2d. Mandible.

3. Male, or drone.

3a. Antenna of ditto.

$3 b$. Hind leg of ditto.

3c. Front view of head of ditto.

3d. Mandible of ditto.

A. Enlarged view of the wing. B. Hind edge of fore wing, showing the thickened margin, and fore edge of hind wing, showing the hooks, which hold on to the thickened margin of the fore wing, and keep them together during flight. 


\section{PLATE II. (PAge 86).}

I. Body of a bee divested of antennæ, legs, and wings, showing the anatomy of the thorax and natural position of the stomach.

5*. The eyes.

a. The stemmata.

$b b b$. The muscles that move the wings.

c. The external covering of the thorax.

$e e$. The bases of the wings.

d. The honey-bag, or first stomach.

$f$. The ventricle, or true stomach, distended with food.

$g$. The rectum.

$h$. The biliary vessels.

i. Portion of the membranous tissue lining the inner surface of the segments, and enclosing the stomach and intestines.

2. The stomach emptied of its contents, to show the muscular contraction of the ventricle.

d. The honey-bag.

f. The ventricle.

g. The rectum.

h. The biliary vessels.

3. The ligula, or tongue, and its appendages.

l. The base of the ligula.

m. The paraglossa.

n. The maxillæ.

u. The labial palpi.

p. The tongue.

4. The sting and its muscles.

s. Curved base of the outer sheath enclosing the sting.

$r$ Muscles that move the sting.

q. The attachment of the muscles to the outer cover. ing of the abdomen.

t. Poison-bag.

u. Glands connected with the poison-bag. 
$\therefore \quad$ Honey-plates covering the muscles $r$, and to which the sheaths of the sting are attached at $s$.

* Base of sting connecting with the poison-bag $t$.

* Tip of the same

4* Magnified view of point of sting, showing the serrations on each side.

5. Three hexagonal prisms of a bee's eye (Swammerdam).

6. Abdominal plates of the bee, detached to show the wax cells.

7. Eggs of bee, natural size, and magnified (from Réaumur).

8. Helminthomorphous or apodal larva of a bee (Réaumur). 


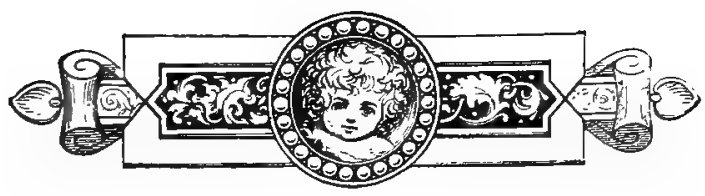

ILLUSTRATIONS.

Frontispiece.-Coloured view of Geo. Neighbour and Sons' Apiary.

Plate I.-Italian Alp Queen, Drone and Worker Bees, with Anatomical Drawings . . . Facing page

PlATE II.-Dissected Bee, with Illustrations of various Members

Common Cottager's Hive

Facing page 86

Neighbours' Crystal Palace Skep

. 108

The Cottager's Hive

. 109

Improved Cottager's Hive .

I 10

Improved Cottage Hive (No. 5)

. II 2

Improved Cottage Hive (No. 6), no windows

. II 3

The Ladies' Observatory Hive . II

Nutt's Collateral Hive . 120

Woodbury's Bar-frame Hive (wood)

. 123

Woodbury's Single Bar Frame as taken from hive

. I35

Woodbury's Bar-frame Hive (straw) I 35

Woodbury's Bar-frame Hive (glass)

Neighbours' New Frame Hive (wood) . 138

Neighbours' Jew Frame Hive (straw), with Frame Super

Neighbours' Cottager's Frame Hive (wood)

. 142

Neighbours' Philadelphia Frame Hive . 
Neighbours' Out-door Unicomh Hive .

Bee House for two Hives-Front view .

Bee House for two Hives-Back view .

. 167

Bee House for twelve Hives-Front view

. 169

Bee Honse for twelve Hives-Back view

. 170

Ornamented Zinc Cover

. $17 \mathrm{I}$

Zinc Cover for Cottager's Hive .

Wooden Cover for Frame Hive

. 172

Neighbours' New Frame Hive, with Cover, Stand, and Pair of

Divisional Supers-Back view.

. 175

Neighbours' New Frame Hive, ditto-Closed front view

. 176

Neighbours' New Frame Hive and Frame Super (glass), with

large Cover and on Stand-Front view .

. 178

Neighbours' New Frame Hive-Front view, closed .

. 178

Neighbours' New Frame Hive (No. 8r). Wood with Straw

Crown, and Large Window in close-fitting Cover and Stand

Bell and Flat-shaped Glasses (5 varieties) . . I8I

Payne's Glasses .

Flap-topped Glass, with Cover for Table

Woodbury Glass-sided Bar Super

Bar-frame Super-Glass Sides and Top, with Shutters

Neighbours' New Divisional Super

. 182

. $1 \dot{8}_{3}$

Neighbours' New Sectional Super

. 184

Neighbours' New Bar-frame Holder

Honey Cutters .

Honey Extractor

Neighbours' Queen and Drone Preventer 
xxvi

ILLUSTRATIONS.

Fumigators (2 illustrations) . . . . . . . 207

Bee Dress or Protector . . . . . . . 209

Bee Veil . . . . . . . 210

Contrivance for protecting Queen Cell . . . . . 244

Guide Comb Glasses . . . . . . . . 263

Weighing Hives $\quad . \quad$. $\quad . \quad$. $\quad .277$

Bees at Exhibition of $1862 \quad . \quad$. $\quad . \quad 348$

Exterior of an Apiary . . . . . . . . . 352

Interior of an Apiary . $\quad$. $\quad . \quad . \quad 353$ 


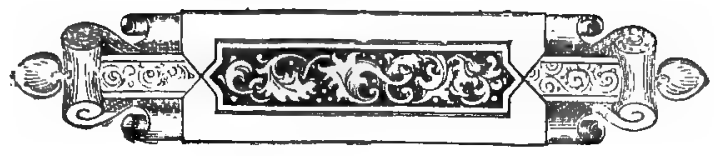

\section{INTRODUCTION.}

\section{LITERATURE OF BEE-KEEPING.}

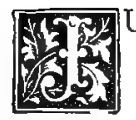

UST a few words at starting on the history of the bee in ancient and modern literature. Our work is not a critical survey, and still less an exhaustive treatise; but even that popular outline which it is our aim to produce seems defective without some mention of the great bee-students of the past. We find the first definitive description of the insect in Aristotle's "History of Animals," written about the middle of the fourth century before Christ, and combining much sound scientific information on our subject with other statements which better information has had to reject. A little before him lived Aristomachus, of Cilicia, who wrote works on agriculture and domestic economy which are lost to us except in a few quotations, but of whom we are told that he devoted some fifty-eight years to a continual observance of the habits of bees. One Philiscus, of Thasos, is mentioned as another of their votaries, who betook himself to a forest life in order uninterruptedly to pursue their study. Then just after the Christian era 
came Pliny the Elder, from whom we learn these few particulars of the two just named, and whose celebrated "Natural History," which is the work rather of a student than of a master, honours the bee with an elaborate and interesting description. Shortly after him Columella, in his work "On Rustic Matters," gave copious instructions on bee-keeping, which, though reproducing some older errors, are greatly in advance of any that had appeared, and place him, for the accuracy that they display, at the head of the apiarians of antiquity. Theophrastus, Celsus, and Varro must also be ranked among the ancient writers whose attention was drawn to this industrious insect. But perhaps the most renowned of classic works upon the subject is the fourth book of the "Georgics" of Virgil, in which we are presented with a minute treatise upon bees and their culture, with all the sense as well as nonsense that then passed current thereupon, together with that most beautiful passage in the poet's writings, the story of the visit of Orpheus to the shades, which is appended by one of those incidental connecting-links of which ancient poets were wont to avail themselves.

In more modern times the principal writers have been Swammerdam, the Dutch naturalist; Maraldi, an Italian mathematician; Schirach, a Saxon clergyman; Réaumur, well known for his thermometer; Bonnet, a Swiss entomologist and jurist; the famous Dr. John Hunter; and above all Francis Huber, of Geneva. The last of these, though totally blind, contrived, principally by the aid of 
his very intelligent and painstaking assistant, Burnens to accumulate a long series of minute observations which have brought about an entire revolution in the science. In connection with Huber must be mentioned Mlle. Jurine, who, by her delicate microscopic examinations, rendered him the most important services, and gave more than one valuable discovery to the world. It the same period lived Dr. John Evans, who may be fitly styled the poet-laureate of the bee. His poem, "The Bees," from which we shall make numerous quotations, is written with great taste, and combines, with rare felicity, scientific accuracy of detail with a poetic spirit which never flags.* A little later than these, though in part their contemporary, came Dr. Bevan, whose name is still cited as among the highest authorities on the subject, and whose work, "The Honey Bee," was regarded as its great textbook in our language, till superseded, with the progress of discoveries, by one under the same title from the pen of the Rev. L. L. Langstroth. This last gentleman, who is a Presbyterian minister in Ohio, stands undoubtedly at

* Dr. Evans's poem consisted of four parts, of which only three were ever published. We possess an author's presentation copy in which is a written memorandum that the manuscript of the remainder had been prepared for the-press, and was still in the keeping of the family. We have written numerous letters with a view to tracking it out for publication ; but very recently we have learnt that the only survivor of nine children is unable at present to discover the whereabouts of the document. Dr. Evans was some time a physician at Shrewsbury, but remored into and died in Wales. 
the present day as the foremost apiarian of the Englishspeaking race. But we are forced to admit that the Germans bear the palm above us, for all the great advances in our knowledge of the bee which have been made for a generation have come from them. To Dr. Dzierzon,* therefore, a Roman Catholic priest of Carlsmarkt in Silesia, to whose acute investigations the great mass of these are to be ascribed, must be conceded a rank scarcely second to that of Huber; while Baron von Berlepsch, of Coburg, who is ever ready to follow up and improve upon the researches of the "great master," has beyond question earned for himself a position inferior to that of the master alone. Of famous Scotch writers we should allude to Bonner, of Glasgow, who lived in the latter part of the last century, and the Rev. Dr. Dunbar, who dates at the beginning of this.

Of the mass of other names that press in upon us it will be impossible in such narrow limits to supply any details. The literature of the subject is truly enormous, and all that we can do is to furnish a list in rough chronological order of the nore noteworthy of those who have in some way rendered service to our acquaint-

* Pronounced Dzeert-sohn. Some of the above names, it may not be amiss to add, are not always spelt correctly by bee-writers. In particular, nearly all of them, copying each other, omit the accent in "Réaumur" (Ray-o/t-mewn), which we find French biographers unanimous in inserting. We have also seen "Miraldi" in a recent popular work, while one author had a fancy to write "Huiber," which is evidently a pure mistake. 
ance with the bee. Besides the great naturalists Linnæus and Cuvier we therefore select the following :-

Sixteenth century.-Hill, Nikul Jacob. "De Proprietatibus I pum" (anon.) published about 1510.

Seventeenth century.-Butler, Purchas, Goedart, Swammerdam, Sir C. Wren, Hartlib, Gedde. Rusden, Ray (with Willughby and Dr. M. Lister), Dr. Martin John (of Germany).

Eighteenth century.-Marald, Mme. Merian, Dr. Warder, Dr. Derham, Réaumur, Thorley, Lyonnet, Vanière (poet, of Holland), Dubbs, Rev. Stephen White, Schirach, Janscha, Bonner, Debraw, Thos. and Danl. Wildman, Gilb. White, Mme. Yicat, Pösl, Abbé Della Rocca, Hubbard, Keys, Bonnet, Riem, Dr. Ino. Hunter.

Nineteenth Century. - François Huber (with bis son Pierre, and Burnens), Latreille, Mlle. Jurine, Spitzner, T. A. Knight, Rev. Dr. Dunbar, Huish, Dr. Evans (poet), Feburier, Kirby and Spence, Humphrey, Baron von Ehrenfels, Newport, Dr. Beran, Gundelach, Lord Brougham, Pastor Oettl, Capt. von Baldenstein, Nutt, Payne, Taylor, Golding, Maj. Munn, Woodbury, Quinby (of America), Wagner (ditto).

Of contemporary writers in our own language, we may, in addition to Langstroth, refer to Rev. W. C. Cotton, Samuelson (with Dr. Hicks), Hunter, Cheshire, and Pettigrew; while to the German names already given may be added those of Professors Leuckart and Von Siebold, Drs. Dönhoff and Küchenmeister, Pastors Kleine and Schönfeld, Vogel, Dathe, Rothe, Count von Stosch, and Schmid, the editor of the Bienenzeitung. It is worth noting how large is the number of apiarians of different lands to whom the title of "reverend" is prefixed.

But while conceding to Germany an unquestioned first position in the theoretical department, we do not 
admit the accuracy of Von Berlepsch's assertion that " in all other countries bee-keeping is almost throughout a mere plaything and amusement." If the Baron would honour our island with a visit, we could show him, from one end of it to the other, a goodly number of very different cases; and though we have much to learn, and have not long gone systematically to work to learn it, there are not wanting clear and increasing signs that the right course is entered, upon, and must in time secure corresponding results. In the year I 874 was established the British Bee-keepers' Association, with one of the first entomologists of the day, Sir John Lubbock, at its head; and under its auspices there have since been held annual shows at the Crystal and Alexandra Palaces, at which bees themselves, their dwellings and paraphernalia, and their products, have been submitted to the awards of judges as well as to the popular inspection. Several periodicals are either wholly or in part devoted to apiculture, and altogether appearances are healthy and hopeful. While therefore we still do look for amusement from our bees, we claim to experience a more solid satisfaction as well.

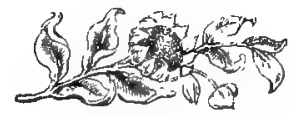




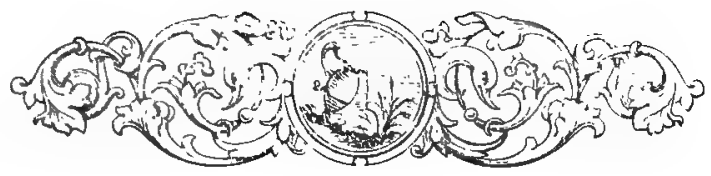

\section{CHAPTER I.}

\section{THE BEE AS AN INSECT.}

\section{$\S$ I. CLASSIFICATION.}

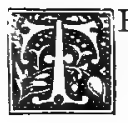

HERE is a self-complacency in commencing a subject scientifically, so let us devote our first half-page to defining the place of the bee in the animal kingdom. The common English honey bee, sometimes called the black bee, is known by the name of Apis mellifica; while the new favourite, the Italian or Ligurian bee, has obtained the specific name of ligustica, though naturalists are now satisfied that the two are only varieties of a single species. The genus Apis belongs to the order Hymenoptera, or membrane-winged insects, which some entomologists have subdivided into families and sections: of these, one family will comprise the honey bees, humble bees, etc.; another the wasps, of which the hornet is one; and others respectively the ants, the gall insects, the saw-flies, and certain parasites and other winged creatures of little familiarity. The entire order belongs to the class Insecta, and that to the grand 
division Articulata, or conjointed animals. In Englar,d alone there are 250 native species of bee.

Turning now to the particular insect with which we intend to interest ourselves, we observe that every hive or bee colony comprises in summer three distinct classes. of bees, each class having functions peculiar to itself, and essential to the maintenance and well-being of the community. As each bee knows its own proper duties, they all work harmoniously and zealously together for the common weal. Certain apparent exceptions to the good-fellowship of the bees will be hereafter noticed, but these arise out of essential conditions in the social. economy of the bee community. That honey bees should live in society, as they do in hives, is absolutely needful. A bee in an isolated condition is a very helpless delicate little creature, soon susceptible of cold, and paralysed thereby unless able to join her companions before night comes on. By congregating in large numbers bees. maintain warmth, whatever the external temperature may be.

The three classes of bees are-the queen bee, or perfect female; the working bees, or undeveloped females; and the drones, or male bees.

\section{§ II. THE QULEN,}

appropriately styled, by German bee-keepers, the mother bee, is the only perfectly developed female among the whole population of each separate colony. Thus her 
majesty indisputably sways her sceptre by a divine right, because she lives and reigns in the hearts of loving children and subjects.

The queen may very readily be distinguished from the rest of the bees by the greater length of her body and the comparative shortness of her wings; her legs are longer, and are not furnished with either brushes or baskets as those of the working bee, for, being constantly fed by the latter, she does not need these implements; the upper surface of her body is of a brighter black than the other bees', whilst her colour underneath is a yellowish brown; * her wings, which do not extend more than half the length of her body, are sinewy and strong; her long abdomen tapers nearly to a point; her head is rounder, her tongue more slender, and much shorter, than that of the working bee, and her sting is curved. Her movements in the hive are measured and majestic, though when out of her proper sphere, as at swarming time, she is distinguished, on the contrary, by the rapidity of her steps. She has a peculiar scent, which is so attractive to workers, that Mr. Mahan, of Philadelphia, states he has several times had them alight upon his fingers, a mile away from his apiary, after he had been handling the royal mother.

It is the chief function of the queen to lay the eggs from which all future bees originate, the multiplication of

* Yellow Italian queens form an exception in point of colour. See Plate I. Fig. 1. 
the species being the purpose of her existence; and she follows it up with an assiduity similar to that with which the workers construct combs or collect honey. A queen will lay in the breeding season from I,000 to 3,000 eggs a day. Both Langstroth and Von Berlepsch have seen queens lay at the rate of six per minute, or more; and the latter observer, on supplying his queen with some new empty comb, found at the end of twenty-four hours that she had laid 3,02 I eggs, which at her observed speed she would accomplish in eight hours, and thus have sixteen for rest. She kept up to nearly this rate for twenty days, in which she filled 57,000 cells; and, what is still more surprising, she went on in like style for five years, during which, at the lowest reckoning, she laid. I,300,000 eggs, or 300,000 per year. But with ordinary queens, says the Baron, I,200 a day is excellently good work, and this rate from February to September, with allowance for slacker periods, will produce more than I 50,000 bees in a year. "Most queens," says Dzierzon, "in spacious hives and at a favourable season, lay 60,000 in a month, ... and a specially fertile queen, in the four years which she on an average lives, lays over a million eggs." This is indeed a.vast number; but when there is taken into consideration the multitudes required for swarms, the constant lessening of their strength by death in various ways, and the many casualties attending them in their distant travels in search of the luscious store, it does not seem that the case is overstated. 
To keep up these heary productive duties the queen requires to eat in corresponding proportions, and these she varies, or the bees vary them for her, in the same ratio with the laying itself. She sucks honey from the cells direct, or has it supplied to her by the workers; and, as an important additional fact, the latter regularly nourish her with pollen already partially digested in their own stomachs.

In a glass unicomb hive-which we shall hereafter describe-all the movements of the queen bee may be traced. She may be seen thrusting her head into a cell to discover whether it is occupied with an egg or honey, and, if empty, she turns round in a dignified manner and inserts her long body-so long that she is able to deposit the egg at the bottom of the cell; she then passes on to another, and so continues industriously multiplying her laborious subjects. It not unfrequently happens when the queen is prolific, and if it is an early season, that many eggs are wasted for want of unoccupied cells; for in that case the queen leaves them exposed at the bottom of the hive, where they are greedily devoured by the bees.

The queen bee, unlike the great majority of her subjects; is a stayer at home. On the second or third day of her princess life she usually sets out on the allimportant concern of her marriage, and when once this is satisfactorily accomplished she never afterwards leaves the hive, except to lead off an emigrating swarm. 
Evans, with proper loyalty, has duly furnished a glowing epithalamium for the queen bee, thus :-

"But now, when noontide Sirius glares on high, With him young love ascends the glowing sky, From vein to vein swift shoots prolific fire, And thrills each insect fibril with desire.

Thence, Nature, to fulfil thy prime decree, Wheels round in wanton rings the courtier bee;

Now shyly distant, now with bolder air, He woos and wins the all-complying fair; Through fields of ether, veiled in vapoury gloom, They seek with amorous haste the nuptial room, As erst the immortal pair on Ida's height Wreathed round their noon of joy ambrosial night."

The loyalty and attachment of bees to their queen is one of their most remarkable characteristics; they constantly supply her with food, and fawn upon and caress her, softly touching her with their antennæ-a favour which she occasionally returns. When she moves about the hive all the bees through whom she successively passes pay her the same homage; she experiences no inconvenience from overcrowding, for though the part of the hive to which she is journeying may be the most populous, way is immediately made, the common bees tumbling over each other to get out of her path, so great is their anxiety not to interfere with the royal progress. A number of them often form a circle round her, none venturing to turn their backs upon her, but all anxious to show that respect and attention due to her rank and station. 
The majestic deportment of the queen bee, and the homage paid to her, are, with a little poetic licence, thus described by Evans:-

" But mark, of regal port and awful mien, Where moves with measured pace the insect queen!

Twelve chosen guards, with slow and solemn gait, Bend at her nod, and round her person wait. Not eastern despots, of their splendour vain, Can boast, in all their pomp, a brighter train Of fear-bound satraps; not in bonds of love Can loyal Britons more obedient move."

Some modification has to be made, however, in the old ideas on this head, though, so long as it is understood that the reverence of the bees for their queen is an official and not a personal reverence, it may be allowed, except as to the existence of a regular guard, to be for the most part true enough. But the government is a limited and not an absolute monarchy, for the workers often impose their own will upon the sovereign. This homage, moreover, is paid only to matron queens, as Dr. Dunbar noted whilst experimenting on the combative qualities of the queen bee. "So long," says he, "as the queen which survived the rencontre with her rival remained a virgin, not the slightest degree of respect or attention was paid her; not a single bee gave her food; she was obliged, as often as she required it, to help herself; and, in crossing the honey cells for that purpose, she had to scramble, often with difficulty, over the crowd, not an individual of which got out of her way, 
or seemed to care whether she fed or starved. But no sooner did she become a mother than the scene was changed," and all treated her with due attention.

The sting of the queen bee is utilised in depositing her eggs, and she does not use it for hostile purposes except in combat with her sister queens. Mr. Langstroth remarks that this forbearance apparently arises from the knowledge that the use of the sting might prove fatal to herself, and thus seriously jeopardise the whole hive. He adds that she will carry it to the extent of allowing herself to be torn limb from limb without an attempt at stinging, though if closely held in the hand she will sometimes use her jaws, which, being more powerful than those of other bees, may occasion some discomfort. But she admits of no rival to her throne; almost her first act, on coming forth from the cell, is an attempt to tear open and destroy the cells containing the pupæ of princesses likely to become competitors. Should it so happen that another queen of similar age does exist in the hive at the same time, then, if one be not promptly destroyed by the workers, as is now considered to be the rule, the two are usually brought into contact with each other, in order to fight it out, and decide by a struggle, mortal to one of them, which is to be the ruler; the stronger of course is victorious, and remains supreme, while her rival either falls dead or is left to die.*

* Dr. Bevan mentions examples both of instant fatality and of survival for twenty-four hours. The sting of the queen is evidently less powerful than that of workers, as her poison-bag is smaller; 
Either of these, it must be admitted, is a wiser method of settling the affair than it would be to range the whole hive under two distinct banners, and so create a civil war, in which the members of the rival bands would kill and destroy each other for matters they individually had little or no concern about. The bees care not which queen it is, so long as they are certain of having one to rule over them and perpetuate the community; indeed, they have been known in some cases to form rings round the respective combatants, and even to force them to the conflict if unaware of each other's presence. But Dr. Bevan tells us that there do exist queens which will not fight. The workers do not always decide the matter in such case; it is, indeed, nothing uncommon, says Vogel, for two fruitful queens to be allowed to live together; and we have had instances of the same kind ourselves, without being able to give a reason other than that "the exceptions prove the rule." An Italian queen, it is said, is usually assisted in her third year by a younger mother born in her own hive.

These royal duels, though no longer regarded as the invariable routine, have been abundantly testified to by undoubted witnesses, and some of these have deduced a singular law as governing the combatants. Neither and we learn from Von Gindly that he once succeeded in inducing a queen to sting him, when the effect was like little more than the prick of a needle. Kleine also, after persevering attempts, was once stung by a queen, and so was Hofmann of Vienna-the queen in this last case losing thereby the faculty of laying. 
cueen, it is said, will sting her rival unless she has her at an advantage, and can thrust her body beneath the other's, and inflict the fatal thrust without fear either of receiving another simultaneously, or of being unable to withdraw her own sting. If on the contrary each has grappled the other in readiness for mutual slaughter, they will at once separate and commence the battle anew.

After perusing the description given above of the attachment of bees to their queen, it may be easy to imagine the consternation a hive is thrown into when deprived of her presence. The bees first make a diligent search for their monarch in the hive, and then afterwards rush forth in immense numbers to seek her. If the search is unavailing they will return to the hive and commence what Langstroth calls "a succession of wailings in the minor key," which no experienced bee-master can mistake. When such a commotion is observed in an apiary the competent apiarian will repair the loss by giving a queen. The bees have generally their own remedy for such a calamity, in their power of raising a new queen from amongst their larvæ; but if neither this nor the former means is available, the whole colony gradually dwindles and in time dies off. The following is the method by which working bees provide a successor to the throne when deprived of their queen by accident, or in anticipation of the first swarm, which is always led by the oid queen :-

They select, when not more than three days old, an 
egg previously intended for a worker bee--but a larva will serve, so it be not grown to its full size-and then they enlarge the cell so selected by destroying the surrounding partitions; they thus form a royal cradle, in shape very much like an acorn-cup inverted. The chosen embryo is then fed liberally with a peculiar description of nurture, called by naturalists " royal jelly" - a pungent food composed of honey and digested pollen, and prepared by the worker bees exclusively for those of the larvæ that are destined to become candidates for the honour of royalty. The effect of this is both to perfect and to hasten the development of the future insect, so that instead of a worker being produced at the end of twenty-one days, a queen emerges in the reduced term of sixteen.

But should the deprivation happen at a time when, either from the season or from abnormal circumstances, there is no worker brood in the hive, the bees will then often exhibit a series of curiuus and even ludicrous struggles, which Von Berlepsch has aptly compared to the clutchings at straws made by a drowning man. Themselves individually are no sufferers; but bees look beyond themselves, and posterity they must have. Their sole preoccupation, therefore, is to raise drones and a queen. Some of them often develop a capacity to lay drone eggs (as explained under $\S \mathrm{ix}$.), and most of these they will carefully cherish for their natural purpose, but others they will surround with royal cells and feed with 
royal jelly, so that the poor things on hatching are soon dosed to death in a frantic effort to change their sex ! And if drone eggs are not to hand they will even try to hatch a queen out of a lump of pollen! In more senses than one then we see that when bees have lost their queen they have lost their head.

As curiously dissimilar, though not discordant, instances of the effect of removing the queen from a hive, we may mention that Mr. Langstroth once tried the experiment for only two or three minutes, when he had all in confusion immediately, and found two days after that royal cells had been prepared; while Dr. Bevan once effected the removal so quietly that for eighteen hours all went on as usual, and then on a sudden the fact became known, and everything was changed into agitation and distraction. Should a queen so separated be detained from her subjects, she resents the interference, refuses food, pines, and dies.

The observations upon the queen bee needful to verify the above-mentioned facts can only be made in hives constructed for the purpose, of which the "Unicomb Observatory Hive" is the best. In ordinary hives the queen is scarcely ever to be seen; where there are several rows of comb she invariably keeps between them, both for warmth and for greater security from danger. The writer has frequently observed in stocks which have unfortunately died, that the queen was one of the last to expire; and she is always more difficult to gain pos- 
session of than other bees, being by instinct taught that she is indispensable to the welfare of the colony.

The queen enjoys a far longer life than any of her subjects, her age very often extending to four or even five years; her fertility will, however, except in rare cases, have left her long before that term, or she will lay only drone eggs, so that as a general rule a substitute is better found for her when she has entered her third year. Under the next section, and those on "Reproductive Economy" and "Relation of Sex to Cells," as well as in Chapter IV. under "Queen Cages," will be found other information connected with the queen.

\section{§ III. THE DRONE.}

The drones are the male bees; they possess no sting, are larger and more hairy than the workers, and may be easily distinguished by their heavy motion, thick-set form, and louder humming. They have a strong odour, which becomes very noticeable if several of them are confined in a box. Evans thus describes the drones :-

"But now, when April smiles through many a tear, And the bright Bull receives the rolling year, Another tribe, to different fates assigned, In ampler cells their giant limbs confined, Burst through the yielding wax, and wheel around On heavier wing, and hum a deeper sound. No sharpened sting they boast; yet, buzzing loud, Before the hive, in threatening circles, crowd The unwieldy drones. Their short proboscis sips No luscious nectar from the wild thyme's lips ; 
From the lime's leaf no amber drops they steal, Nor bear their grooveless thighs the foodful meal :

On others' toils, in pampered leisure, thrive The lazy fathers of the industrious hive.

Yet oft, we 're told, these seeming idlers share The pleasing duties of parental care,

With fond attention guard each genial cell, And watch the embryo, bursting from its shell."

But Dr. Evans had been "told" what was not correct when he sought to dignify drones with the office of "nursing fathers" ("brood bees" as the Germans used to call them), for that task is undertaken by the younger of the working bees. Nor are they even utilised in maintaining warmth, for they are expelled just at a time when warmth is most required. No occupation falls to the lot of the drones in gathering honey, nor have they the means provided them by Nature for assisting in the labours of the hive. They are the progenitors of working bees, and nothing more; so far as is known, that is the only purpose of their short existence.

In a well-populated hive the number of drones is computed at from one to two thousand. "Naturalists," says Huber, "have been extremely embarrassed to account for the number of males in most hives, which seem only a burden to the community, since they appear to fulfil no function. But we now begin to discern the object of Nature in multiplying them to such an extent. As fecundation cannot be accomplished within the hive, and as the queen is obliged to traverse the expanse of 
the atmosphere, it is requisite that the males should be numerous, that she may have the chance of meeting some one of them in her flight. Were only two or three in each hive there would be little probability of their departure at the same instant with the queen, or that they would meet her in their excursions; and most of the females might thus remain sterile." It is important for the safety of the queen bee that her stay in the air should be as brief as possible, as her large size and slowness of flight render her an easy prey to birds. It is not now thought that the queen always pairs with a drone of the sume hive, as Huber seems to have supposed. On the contrary, it would appear that with bees, as with so many other animals, there is a provision against such interbreeding. Mr. John Hunter, in his "Manual of Bee-keeping," speaks of this as amounting to a law, and thus represents the fact as diametrically opposite to Huber's conclusion. But we believe the question to be complicated by another-whether the drones that inhabit a particular hive at any given time are regularly born of the same family with that hive, or whether they are not very often to be viewed as "strangers within the gates." At all events, it appears established that the queen and drones within a hive do watch each other's movements when the former is about taking her nuptial flight, and that the union is sometimes consummated close at hand, though certainly never attempted within the precincts of the hive itself. This last circumstance, which by all 
accounts is absolutely invariable, would seem to be the extent of the provision, and it is one that in ordinary circumstances would preclude the recurrence of in-and-in breeding. A confirmation of these views is afforded from the interesting experience of Captain von Baldenstein with his one Italian stock maintained by itself for seven years, who found that all this time, zcith one exception, the young queens produced bastard workers, clearly proving that all but that one were impregnated by the drones of other colonies.

The drone that happens to be the selected husband is by no means so favoured as at first sight might appear, for it is a law of Nature that the bridegroom does not survive the wedding-day. His death, however, is doubtless generally instantaneous, whereas in other case it would probably have been one of torture or starvation. In 1867 the German apiarian Von Klipstein was witness of an instance of the wedding ceremony, when a young queen, who was leading a swarm, became detached from it and settled upon a currant bush, where she was joined by a drone; after a few seconds the two flew away together for three yards and then fell to the ground, when the queen disengaged herself, and the drone was found to be dead. But we learn from the American Bee Fournal, of March 186r, that two similar cases were observed in the United States some years earlier than this. The latter of these two agreed with the above in showing the immediate death of the male bee, the rule 
as to which is also confirmed by a fact noticed by Mr. Langstroth, that if a drone is taken between the fingers and squeezed, as one would squeeze a wasp to cause protrusion of the sting, it will give a crack and shrivel up dead as if struck by lightning. The instance in point was also communicated to the Bee Fournal through this gentleman, it having been noticed, on a July afternoon in 1860 , by his friend Mr. W. W. Cary, of Coleraine, Massachusetts. The queen was returning from a presumably unsuccessful flight, when a drone met her at about three feet from the hive entrance; a sharp snap was heard almost directly, and the male fell to the ground perfectly dead. The other case was witnessed by the Rev. Mr. Millette, of Whitemarsh, Pennsylvania, and occurred in June 1859 , during the process of hiving. A young queen-there were four in the swarm-" "was observed on the wing, and in a moment after was seized by a drone. After flying about a rod they both came to the ground in close contact; . . . the drone was about departing (having broken loose) . . . but after crawling about . . . in a very few minutes it expired "-the circumstance being probably quite exceptional in this lapse of minutes, and it is unfortunate that we have no information as to the immediate or subsequent effect upon the queen.

As a general rule the royal lady, not meeting drones straightway upon her issue from the hive, spends a little time in reconnoitring her home, and then, often not till 
her second day's exit, sails away high into the air, and sometimes to a considerable distance horizontally as well. "A Renfrewshire Bee-keeper" states in the British Bee Foumal, of May 1877 , that an undoubted instance had come to his knowledge in which a common queen, located five miles distant in a bee-line measured upon the Ordnance map, had become impregnated by one of his own Italian drones-these being positively the only Italians in the entire district.

On the queen's return - that is, supposing her object to have been achieved-she will exhibit the male organ adhering to her extremity, and sometimes she is unable to free herself of it, nor can the bee-keeper give her any assistance without the risk of effects as fatal to herself as they were to her spouse. The explanation of this series of phenomena lies in the structure of the organ itself. It is simply the expanded prolongation of the seminal duct, and is attached to the orifice like the sleeve of a coat to the shoulder, but is wholly internal. To be protruded it must therefore be turned literally inside out, and to effect this a powerful inflation is required, in which act the forces of the system are in some way fatally ruptured; while, as Professor Leuckart very rationally deduces - thus clearing up another mystery -it is only when the breathing vessels are filled by motion in the air that the drone is able to accomplish it at all. Then the singular scales and protuberances with which the organ is beset render it when once inserted 
very difficult of withdrawal, even if its owner were not already dead. Mrr. Langstroth remarks as to the design of this seemingly harsh provision that in default of it the queen would be compelled to remain with the drone much longer in the air, thus incurring far greater danger of falling a prey to some passing bird. After all it is undoubtedly one of those instances as to which it may be said of Nature, in Tennyson's words,-

\section{'So careful of the type she seems, so careless of the single life."}

Her majesty, although thus left a widowed, is by no means a sorrowful bride, for in from two to three days she becomes the happy mother of a large family. Such at least is the normal rule, but should the season be late in the autumn she may not commence laying till the following spring. It cannot be said that she pays no respect to the memory of her departed lord, for she never marries again. Once impregnated-as is the case with most insects - the queen bee continues productive during the remainder of her existence.

The swarming season being over-that is about the end of July, when the gathering has materially slackeneda general massacre of the "lazy fathers" shortly follows. Dr. Bevan observes that now their work is completed, " they are regarded as useless consumers of the fruits of others' labour: love is at once converted into hate, and a general proscription takes place." For it was love, 
the drones having previousiy been petted and fed with prepared pollen in the same way as the queen herself. Von Berlepsch describes the work of destruction as commencing with the casting forth of the drone brood just issuing from the cells, after which the larvæ and nymphs are similarly treated. Then the drones themselves are chased from the honey stores, and a watch is kept to prevent their access thereto. On finding it hopeless they crouch away together in corners, till, when thoroughly exhausted by hunger, the workers drive them out one by one, and they die with cold and hunger: very few of them are stung. This work goes on night and day, and occasionally they collect to die in such a heap before the flight-hole that there is a danger of their suffocating the hive. Disabled or useless workers are dealt with in an equally summary fashion; but in the case of a superannuated queen, the best opinions are that she is allowed to take her own quietus.

Supposing the drones come forth in April or May, which is the usual period, then, as their destruction takes place somewhere about the commencement of August, three or four months will be the ordinary extent of their existence; but should it so happen that the development of the queen has been retarded, or that the hive has by chance been deprived of her, the massacre of the drones is deferred. On the other hand, in case of the cutting short of the gathering season by bad weather, it occasionally happens at an earlier date-even so soon 
as May. Now and then a drone or two escape, and prolong their lives through the winter.

\section{\$ IV. THE WORKER.}

The working bees form by far the most numerous ot the three classes contained in the hive. They are the smallest of the bees; in colour they are dark brown or nearly black (except the Italians and other foreign varieties), and they are distinguished by their activity upon the wing. As to their numbers in a colony, "an ordinary first swarm from a straw hive," says Von Berlepsch, "contains from twelve to twenty thousand, but I have had large wood hives in which, at a moderate computation, there were living at the end of June about a hundred thousand bees:" from thirty to fifty thousand, however, will better represent the strength of an average stock in an English hive. The worker, though formerly spoken of under the term "neuter," is of the same sex as the queen, but is only partially developed, and thus, with some exceptions (see $\S \mathrm{ix}$.), it . is incapable of laying eggs. But any egg which would ordinarily produce a worker bee may, by the cell being enlarged and the "royal jelly" supplied to the larva, be hatched into a mature and perfect queen. This most curious fact may be verified in any apiary by most interesting experiments, which are capable of being turned to important use.

The lives of the worker bees vary very greatly, and 
are much more prolonged during the repose of winter than in the wear and tear of the gathering season. Von Berlepsch describes three careful sets of experiments which he carried out for the purpose of attaining more exact knowledge on this point. In one of these he introduced an Italian queen into an ordinary stock at the beginning of October when all the old brood was hatched; he then found as a result that the last of the common bees had disappeared at the end of May, so that some of them for a certainty lived eight months, and possibly more, though it seems most probable that the last to die were also the latest born. In another case, the queen having died at the commencement of winter, he strictly isolated the hive, and, the season being exceptionally mild, he found that some of the bees continued alive for ten and a half months. His remaining experiment bore upon the summer term of existence, and it resulted in exhibiting six weeks as the average, and three months as the outside possible period of lifetime. Dzierzon points out the difference produced by the character of a bee's employment. To have to fly a long distance to its pasturage will soon wear it out, and so will knocking its wings against sharp leaves, as is the case with the bluebottle, the thick corn amid which this plant grows rendering the effect very much worse. But if, he adds, they pass the summer in entire repose, as a hive without a queen may do, then, if well fed, their lives may be prolonged for a year or eqien more. 
The population of a hive is very small during the winter in comparison with the vast numbers gathering produce in the summer-produce which they themselves live to enjoy but for a short period. So that not only, as of old, may lessons of industry be learned from bees, but they also teach self-denial to mankind, since they labour for the community rather than for themselves. Dr. Bevan, in describing the age of bees, thus adapts the well-known lines of Homer in allusion to the fleeting generations of men :-

"Like leaves on trees the race of bees is found,

Now green in youth, now withering on the ground;

Another race the spring or fall supplies,

They droop successive, and successive rise."

With regard to the functions of worker bees, Huber supposed that there were two distinct classes, one acting as gatherers of store and the other as nurses of brood. This however has been demonstrated to be a mistake, for the distinction is not one of class, but simply of age, the younger workers, for the first two or three weeks of their existence, ${ }^{*}$ assuming the whole of the inner or home occupations - viz., those of feeding the larvæ, the queen, and the drones, and of making wax, building comb, and closing the cells, as well as keeping

* German observations cited by Von Berlepsch give from ten to nineteen days. The Baron gives provisionally the sixicenth day as the rule. The first sporting before the hive is given at from the fourth to the tenth day. 
the hive in a state of cleanliness - and these duties they retain until themselves sufficiently vigorous to range the fields in quest of supplies. After this term of apprenticeship they enter upon the labours of adult bees, and collect honey, pollen, and propolis-particulars as to which functions, and that of wax secretion, will be found in the third and fourth sections of our next chapter, and in the sections devoted to these four items in Chapter VI. Water and salt are also brought in to aid in the sustenance of the young brood. The older bees perform the duties of the younger when there are none or insufficient of the latter in the hive; but they will hang about perfectly idle if kept at home by weather when there is a full staff of their younger sisters. These last, on the contrary, cannot possibly supply the places of the older until at the very least they have attained their eleventh or twelfth day.

Another of the varied duties performed by the younger worker bees is that of ventilating the hive by fanning with their wings. On a warm day a number of them may be seen located outside on the alighting-board working these appendages at the utmost velocity so as to drive a current of pure air within; while inside, but not exactly opposite to their comrades, are another troop, who by the same process are engaged in driving the foul air out. Other detachments are in the hottest weather posted in different parts of the interior, and the whole relieve each other in pickets. Huber ascer- 
tained that the inside air of a hive is thus preserved nearly as pure as that without.

In older works on the subject we are told of the sentinels of bees, but this idea is now abandoned as a fiction. It arose naturally enongh out of the above office of fanners, as well as from the fact that if a rap be given upon the alighting-board a bee will immediately appear without. So too if danger appears, and if any bees are outside either as fanners or for their own relief from the heat, these will promptly perform the duties of sentinels. But as to any of them being posted specially for that purpose, it is sufficient to say that at the season when enemies are most to be feared there are no guards at the gates to be found.

It has been much queried whether bees ever go to sleep during the working season, as it is known that at night, when not gathering abroad, they are engaged in ceaseless activity at home. Huber, however, observed frequent instances of bees placing their heads' in empty cells and remaining perfectly motionless in that position for from fifteen to twenty-five minutes, in his opinion evidently asleep. Von Berlepsch has repeatedly observed similar occurrences both with workers and queens-not with drones, but then, says he, what is the whole life of these but sleep?-and he considers that there can exist upon the point no doubt whatever. "The more active the bees are," he remarks, "the more will they sleep, like every creature." 
The following passage from Dzierzon describes in a popular way the round of the bees' concerns as they vary with the seasons: "In spring, when all Nature has awakened to a new life, the activity of the hive is especially directed to the increasing of the stock, the laying of eggs ; at first, indeed, none but worker eggs are laid, and at the outset only a few hundred cells in a day, but afterwards thousands, as every hive seeks in the first place to make its own continuance secure. When gradually the number of bees has through the daily augmentation become perceptibly increased, when the pastures have more fully unfolded themselves, and the warmth in the hive has reached a higher degree, then, in the confidence of strength and of a sort of maturity, and having regard to the remoter object of increase through connubial relations, drone brood is also laid. Finally, although not in every case, in greater or less number queen cells are prepared. As soon as one or other of these is sealed over, the old queen feels no longer safe in the hive, and leaves it on a fine day at noon with the so-called 'fore-swarm.' . . . . . In most years and most districts the bee store has passed its climax and entered upon its decline after the swarming period. The activity of the bees now takes another direction. In order to leave over as much honey as possible for the provisicniess season that stands before them, a system of saving is now pursued. To compensate for the maroidable loss of population from the journeys 
abroad, a certain quantity of worker brood is still continually set on, but to a limited extent, while the breeding of drones is not only given up, but the already deposited drone brood is usually thrown out, and the drones themselves, as no longer of any use, are expelled from the hive. Comb-building too, which the bees so eagerly carried on in the spring, now rests entirely, as it would consume honey, and at the first autumn gathering the bees in fact fill all cells to hand with honey, though previously these may for the most part have served for brood-rearing. Their activity is now bent to securing their future position by accumulating the largest possible store of honey, and preserving themselves against draughts and cold by stopping up the holes in their dwelling with propolis, and narrowing the too wide flight-holes; and these cares generally occupy them so long as the temperature is of such a degree that they can still make their flights, which is up to about I 3 degrees Réaumur [say 6o Fahr.] . . . When there is nothing more to gather, the bees, in order to save strength as well as honey, fly out no longer, even on the finest days, but preserve themselves in complete repose, and only undertake, after several days, an occasional sport before the hive on some warm noonday, so as to cleanse themselves once more before the winter."

Dr. Evans addresses and describes the worker bee in two passages of such real beauty that we cannot refrain from giving them a place here:- 
"Ye light-winged labourers! hail the auspicious sign, When the twin stars in rival splendour shine!

Cheered by their beams, your quickening numbers swell, And pant your nations in the crowded cell. Blithe Maia calls, and bids her jocund train Breathe the warm gale, or softly falling rain ; Inhaled at every pore, the dewy flood Spreads the young leaf, and wakes the'sleeping burl.

Yes, light-winged labourers! still unwearied range

From flower to flower, your only love of change !

Still be your envied lot, communion rare,

To wreathe contentment round the brow of care !

No nice distinctions, or of rich or great, Shade the clear sunshine of your peaceful state;

Nor Avarice there unfolds her dragon wing, Nor racked Ambition feels the scorpion sting; Your tempered wants an easy wealth dispense, The public store your only affuence : For all alike the busy fervour glows, Alike ve labour, and alike repose ; * Free as the air, yet in strict order joined, Unnumbered bodies with a single minct. One royal head, with ever-watchful eye, Reins and directs your restless industry, Builds on your love her firm-cemented throne, And with her people's safety seals her own."

\section{$\S$ V. THE ITALIAN OR LIGURIAN BEE.}

A new, or rather a re-discovered, variety of bee has recently been brought into practical use amongst apiarians in Germany and America, as well as in this

* "Omnibus una quies operum, labor omnibus unus."

$$
\text { Virgil, G. iv, I } 84 \text {. }
$$


Plate. I.

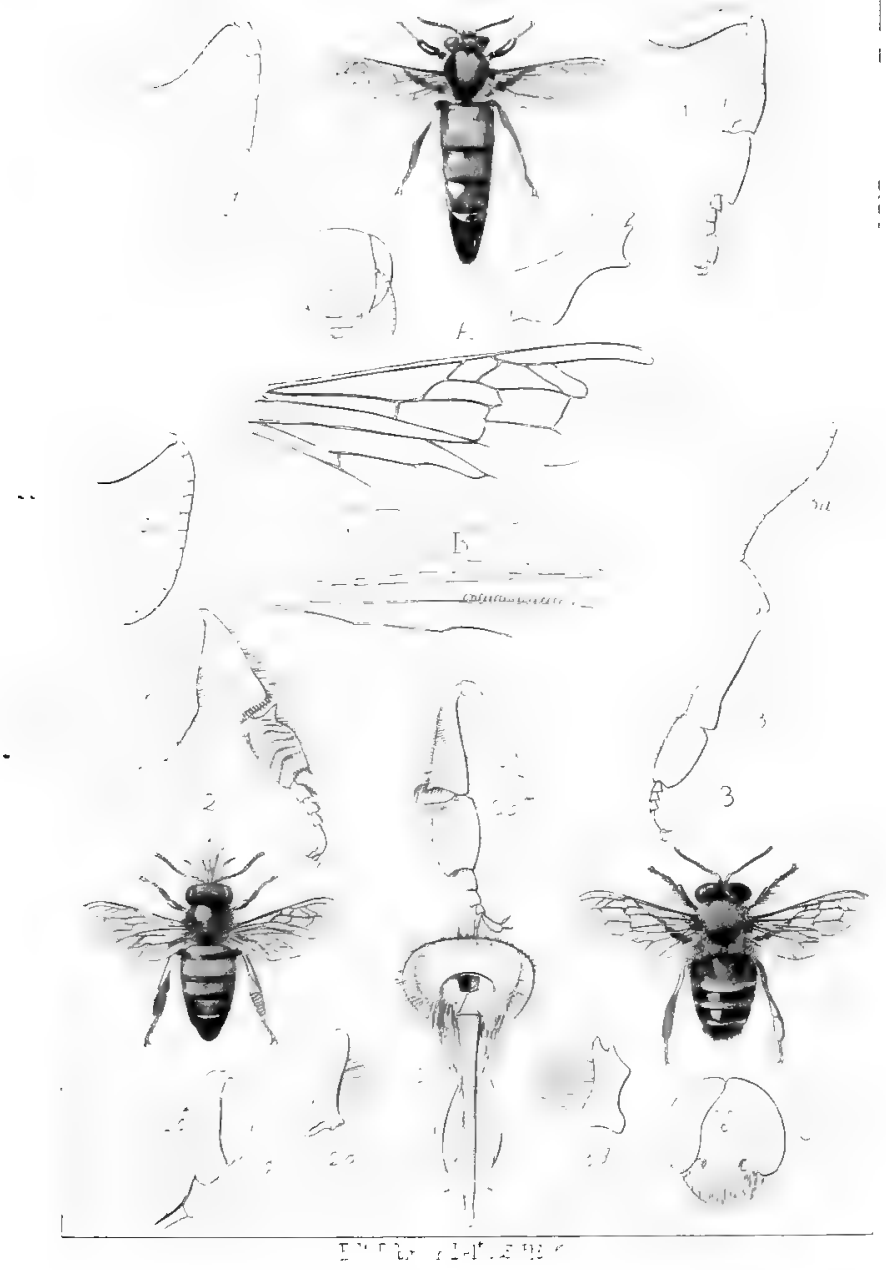



country. It has been called "the Yellow Italian Alp Bee," and was also named "the Ligurian Bee" by the Marquis de Spinola, who found it in Piedmont in 1805 ; and he considered it to be the principal species known to the Greeks. "There can exist no doubt," says Kleine, in his handbook, "The Italian Bee and its Culture," " that both kinds were known side by side from the earliest times. Even mythology relates that Jupiter, out of gratitude for their having fed him with honey when a new-born god, afterwards made the bee 'brass-coloured' or 'golden-coloured.' Aristotle also noticed the coloured as different from the black bee, and Virgil adduces the same distinction." The latter speaks of the "best kind" of bee as being of a golden colour with ruddy scales. It is stated that it is found also in Spain. Leading apiarians are all but unanimous in pronouncing these bees justly entitled to the high character given them. The special advantages claimed for them are-greater fecundity of the queens, more industry and productiveness, less irascibility, and a more handsome appearance; for, being of a golden colour, they are prettier than our black bees. (See coloured engraving, Plate I. Figs. I, 2, 3.)

The Italian varies but little from the common bee in its physical characteristics. The difference in appearance consists in the first three rings of the abdomen being of an orange colour instead of a deep brown, ex cept the posterior edge and under portion of the third, which are black: some individuals, however, have icss 
colour about them than others-the younger bees far the most. These orange-coloured parts are transparent when closely examined with the sun shining on them. The drones are more darkly ringed than the workers, and are light-yellow beneath, which is an infallible mark of distinction from the English drones, which are nearly white in that part; many are also a fourth part smaller than the English. The queens vary greatly: "The finest and rarest," says Von Berlepsch, "are bright yellow varying into a bluish. Others rather resemble the workers, exhibiting only yellow rings; and a few are very difficult or impossible to distinguish from our own. From this we see that the Italian is not a constant race, like, e.g., our own or the Egyptian."

It is now over thirty years since attention was recalled to this variety by Captain von Baldenstein, who, when stationed in Italy during a part of the Napoleonic wars, had observed that the bees about Lake Como were of a different colour from ordinary ones. In later years, after his retirement from military life, he became a student of natural history, and, remembering these bees, he procured a colony of them in 1843 . This he preserved, through constant disappointments, for seven years, and in 1848 he communicated to the Bienenzeitung the deductions of his experience. From this Dr. Dzierzon was induced to pursue the experiment, and from him the variety became introduced in Germany.

The introduction of this new variety of bee into Eng- 
land was through our agency. M. Hermanı, a bee-cultivator at Tamins-by-Chur, Canton Grison, Switzerland, wrote to us on the 5 th of July, I 859 , offering to supply us with Italian queen bees. The date should be specially noted, because this was the commencement of a new era in bee-keeping in this country. We were always in friendly intercourse with the late Mr. H. Taylor, author of "The Bee-keeper's Manual," and then correspondent on Bee Culture to the Cottage Gardener (since called the Fournal of Horticulture); and, being in the practice of frequently discussing apiarian subjects with him, we told him of the offer made us of a new kind of bee. He said he knew nothing about it himself, but asked permission to publish the intelligence in the journal he was connected with, and we assented, entirely for public interest and to gratify him. The letter, or an extract from it, appeared accordingly in the current number of the journal referred to. Prior to this the Italian, or, as many have called it, the "Ligurian" bee, was UNKNOWN IN THIS COUNTRY, except to a few naturalists. The same letter attracted the attention of that intelligent apiarian, the late T. W. Woodbury, Esq., so well known as the "Devonshire Bee-keeper." On the I 9 th of July, that is, a fortnight after M. Hermann's offer, we received a consignment of Italian bees-the first imported into England. With these Mr. Woodbury also received one queen bee and a few workers, which he introduced into a hive of English bees from which the queen had been 
removed. His efforts were very successful, and "the spring of 1860 found him in possession of four Ligurianised stocks." His subsequent experience with this new variety he fully described in a communication to the Bath and West of England Agricultural Fournal.

Subsequently M. Hermann sent us a copy of his pamphlet entitled "The Italian Alp Bee ; or, the GoldMine of Husbandry," with the request that we should have it translated from the German, and that copies of it should be printed in the English language. It was speedily published by us accordingly, and, although singular as a literary production, it may be useful for the advanced apiarian.

Certainly the bees are partially of an orange or golden colour, and if one could believe the golden anticipations indulged in by M. Hermann respecting them, these would be sufficient to identify the Italian bee as the species described by Hood in "Miss Kilmansegg" — those which dwelt in

"A golden hire, on a golden bank,

Where golden bees, by alchemical prank,

Gather gold instead of honey."

In the pamphlet referred to, M. Hermann gives the following description of what he insists on designating as Apis helvetica: "The Yellow Italian Alp bee is a mountain insect; it is found between two mountain chains to the right and left of Lombardy and the Rhetian Alps, and comprises the whole territory of Ticino, Val Tellina, 
and the southern Grisons.* It thrives up to the height of 4,500 feet above the level of the sea, and appears to prefer the northern clime to the warmer, for in the south of Italy it is not found. The Alps are their native country, therefore they are called Yellow Alp or tame house bees, in contradistinction to the black European bees, which we might call common forest bees, and which, on the slightest touch, fly like lightning into your face. [?]

"As all good and noble things in the world are more scarce than common ones, so there are more common black bees than of the noble yellow race, which latter inhabit only a very small piece of country, while the black ones are at home everywhere in Europe, and even in America."

Our own experience with the Italian bee enables us to corroborate the statements which have been made in its favour. We find the queens more prolific than those of the common kind, and the quantity of honey produced is greater. These two facts stand as cause and effect : the bees being multiplied more quickly, the store of honey is accumulated more rapidly, and the Italian bees consume, if anything, less food than the common kind. When of pure Italian blood these bees are, by

* Otherwise Tessin, Veltlin (French Valteline), and the southern Graubiinden. Von Berlepsch names the localities they inhabit as Genoa, Venetia, Lombardy, and the southern valleys of the Grisons bordering upon Italy. 
some apiarians, thought to be hardier than our own. That they forage for stores with greater eagerness, and have little hesitation in paying visits to other hives, we can testify from our own observation. The following anecdote will illustrate their intrusive propensities: Another bee-keeper, who lived in the same neighbourhood, was once inspecting our hives, when, on observing the yellow bees, he exclaimed, "Now I have found out where those strange-looking bees come from; for," said he, "these yellow-jackets are incessant visitors to my hives. I thought they were a species of wasp that had come to rob, and until now I have been unable to account for their appearance at the entrance of my hive, so that I have killed them by hundreds." This was not at all pleasing intelligence for us, and we trust that our neighbour has been more lenierit to "the yellow-jackets" since his visit, for such summary capital punishment was wholly unmerited, because when a bee is peaceably received (see page I69) it becomes naturalised, and works side by side with the others in its fresh abode. We are inclined to believe that more visiting takes place amongst bees of different hives than bee-keepers have been accustomed to suppose ; but where the Italian and. black bees are kept near each other, the foreigners being conspicuous by their lighter colour, there is less difficulty in identifying them when at the entrance of other hives. Von Berlepsch, we find, remarks that there exists during the gathering season a species of "com- 
munism of dwellings" between the bees of neighbouring hives.

The Italian bees are more active than common bees when on the wing. They are also observed to work longer hours than other bees both early and late, as well as in seasons when the latter will not stir abroad. Thus altogether they are much more productive. In many seasons we have had more honey from an Italian stock than from any one of our colonies of black bees. From this hive we have taken a glass super containing forty pounds nett of honey, besides having drawn from it an artificial swarm; and after all it remained the strongest hive in our apiary.

In a private letter received from Mr. Langstroth he informed us that in the season of 1865 he bred over 300 Italian queens; these he disseminated to various bee-masters on the American continent, and the united opinion of apiarians in that country was increasingly in favour of the decided advantage of the cultivation of the Italian bee. At the present date it is literally "all the rage" with bee-keepers there. With ourselves there is a quieter but not less genuine welcome accorded to it. In the British Bee Fournal for May 1877 , the distinguished apiarian "A Renfrewshire Bee-keeper" writes : "After careful study and comparison of both I found the Italian superior for beauty, prolificness, power, and activity, and (to my view the greatest value of all) for fresh blood." 
To the testimonies already cited we will now add that of the late Mr. Woodbury. The following is extracted from the paper contributed by him to the Bath and West of England Agricultural Fournal: "From my strongest Ligurian stock I took eight artificial swarms in the spring, besides depriving it of numerous broodcombs. Finding, in June, that the bees were collecting honey so fast that the queen could not find an exnpty cell in which to lay an egg, I was reluctantly compelled to put on a super. When this had been filled with thirty-eight pounds of the finest honeycomb,* I removed it, and as the stock hive (a very large one) could not contain the multitude of bees which issued from it, I formed them into another very large artificial swarm. The foregoing facts speak for themselves; but as information on this point has been very generally asked, I have no hesitation in saying that I believe the Ligurian honey bee infinitely superior in every respect to the only species that we have hitherto been acquainted with."

The chorus of praise is not however universal. Most noticeable is the broad divergence of views between the two greatest apiarians of Germany-Dr. Dzierzon and Baron von Berlepsch. The former pronounces this bee less given to stinging, less sensitive of cold, more prolific, earlier in brood-raising and swarming, forwarder also in

* This super was exhibited at our stand in the International Exhibition of 1862. 
comb-building, more industrious and honey-yielding, more courageous in defence of its stores, and prompter in expelling the drones. The Baron examines these and other assertions one by one, and declares emphatically that, after a long course of experience, he has not found them true in a single particular. He calls the bee "the Italian humbug," and sums up as follows: "While it may perhaps be distinguished from our own by a somewhat slighter disposition to sting, but, on the other hand, it begins building drone comb and raising numbers of drones in the first year, and its queens grow unfertile so early, and that mostly at so inopportune a time, it stands manifestly inferior to our ozen in a relation of economic utility, and has therefore for us no practical value at all."*

Though we are unshaken in our adhesion to the Italian bee by these opposite views, it is impossible to/treat them as beneath consideration. They are not a mere prejudice, for the Baron was at first as much prepossessed in the strangers' favour as any one. But it would be still less possible to set aside on their account the united testimony of Dzierzon, Langstroth, and a host of others who are above delusion on such a point. How then can we account for this one notable divergence? In the first place, much of Von Berlepsch's data are negative

* In our previous editions Von Berlepsch's views were cited as strongly farourable to the Italian bee. The change is his own, and he now makes full recantation of his "error." 
only, and negative evidence can never set aside positive: thus when he tells us that he "has not observed" earlier activity or greater courage or less sensitiveness, while others of unquestioned judgment have observed these points, we cannot hesitate to decide in the favour of the latter. As to less disposition to sting, the positive evidence should be on the Baron's side when he says that they do sting; but in this case, as we have seen, he partly concedes the point. As to productiveness and fecundity, there may be some undetected peculiarity about this bee to which something in the Seebach apiary or neighbourhood is not so congenial as in other parts. At all events, Dr. Dzierzon is unmoved from his faith, for we find him in the present year giving as the result of twenty-five years" experience that this bee is " as gentle, diligent, and prolific as it is beautiful;" that it "bears our German climate well, and that its preservation in purity is with some care quite possible."

Still some persons are sure to be disappointed with a foreign bee, just as some will be with a foreign country. Some have had their expectations raised too highly, and expect wonderful results to follow without effort; otliers, on the contrary, are so wrapt up in the new treasure that they cherish it with vastly greater pains than their other bees, and thus attribute to the bee itself what is partly to be credited to their own superior care. In particular, with regard to the greater fecundity of the queens, we think some allowance ought to be made for the circumstance 
that in order to meet the demand for Italian queens they are being continuously bred, so that when united to English stocks they are always young and in the prime as to fertility; whilst the common black queens are allowed to exist in the hives their appointed time, as there is nothing to call for encouraging their special propagation. In making comparisons we think this fact has been a little overlooked; but though too much may have been thus credited to the Italians, we think there is a clear balance on this point in their favour, and they retain altogether our most decided preference.

\section{§ VI. OTHER FOREIGN VARIETIES.}

I. Carniolan BeEs.-In appearance this variety is very much like our English bee. The difference is that the rings on the abdomen are whiter; otherwise (except by a close observer) one would not be known from the other.

Eight years ago the Rev. W. C. Cotton (brother of Lord Justice Cotton and author of "My Bee Book") had a stock of these bees from Austria, where they are largely cultivated, and he left them under our charge. We placed them in our own apjary at Hampstead, where they did very well, working a capital super in the first year, as well as parting with a fine swarm. The second year Mr. Cotton had the swarm sent to his own apiary, near Chester, because he wanted the original queen, which of course this had with it. This swarm had rather 
a remarkable adventure, and was nearly lost, as related at page 78. The Carniolans have been praised as possessing similar good qualities with the Italians, and though Von Berlepsch laughs at them and calls them "a new grand swindle," yet, as he declares them to be "closely allied, if not altogether identical," with the following variety, for which he has only good reports, his denunciations of these seem reasonably open to qualification.

2. Lower Austrian Bees.-Baron von Berlepsch mentions these as a variety which he found, to his surprise, in the neighbourhood of Vienna, but which must have been the same that Von Ehrenfels had cultivated and described. They scarcely differ from the Carniolan, but about one in fifty is rather strongly marked with red upon the first ring of the back. The Baron speaks of their habitat as "the El Dorado of the Bee," and he declares them wholly free from the vices of the next sort, and thinks they raise fewer drones than ordinary bees. He recommends, as likely to be a profitable breed, a cross of these with our own variety.

3. Heath Bees. - This is a race of a very different character, deriving its name from the district known as Luneburg Heath, and found also about Oldenburg, Schleswig, and Holstein. In form and appearance Heath bees are wholly identical with our own, but they seem like bees in a lower state of civilisation, perpetually swarming without occasion and with unmanageable impulse, and producing principally drones and drone comb even with 
a queen of the first year. "Undoubtedly," says Von Berlepsch, "this is by far the worst kind of bee existing in Germany."

4. Greek or Cecropian Bees.-In some particulars these are like a cross between the Italian and common bees. The queen is dark bronze on the abdomen as far as the second scale, but the common colour above. Most of the workers have a ring and a half of bronze or a reddish rust-colour; some have two entire rings of this hue. They are stated to be more industrious and productive than common bees, and the drones to be smaller.

This and the two previous varieties we thus briefly notice on the basis of the remarks of Von Berlepsch. We are not aware that either of them has been introduced into this country, nor do they appear to have attained much success in Germany. 'Thus humorously does our author dismiss this last: "Since 1864 , when Deumer sounded his trumpet with distended cheeks, we have heard not so much as a last dying speech from the Cecropian bee, and she seems already in Germany to have gone the way of all flesh. May' the earth lie lightly on her !"

5 and 6. Cyprian and SmyrnaAn Bees.-_"A Country Doctor" writes in the British Bee Fournal that he had prepared a translation from the Bienenzeitung of an article by Herr Corri, in which he speaks most highly of the good qualities of the Cyprian bees, and considers 
them in advance of any other bee that he has cultivated. In this opinion he is borne out by Count Rudolph Kolowrat of Tabor.

"It so frequently happens," proceeds the correspondent, "that the last pet receives the highest honours, and we are so apt to believe that that must have special value which has cost considerable pains to obtain, that a certain amount of caution is advisable in receiving these enthusiastic statements. Herr Corri's opinion, however, is deserving of the highest respect; for both he and the Count have been most perseveringly engaged for many years past in importing various races of bees from their native lands, and making comparative observations as to their merits, and this without being biassed by the expectation of commercial gain.

"The bees got from Smyrna (1864) seem to stand next in their estimation. Both the originally imported stocks, and those subsequently raised from them, presented, however, a certain number of black bees, and after the most painstaking attempts to breed them pure the results remained the same. The conclusion come to was that they were of a mixed race."

Our own experience tallies very much with this opinion. We imported from Germany stocks of both the Cyprian and Smyrnæan bees, and exhibited them at the bee shows of the British Bee Association. Previous to doing so we submitted specimens to Mr. F. Smith of the British Museum, and he reported favourably of them-that al- 
though resembling the Italian (Apis lisustica), the Cyprian were clearly of a different species, but more nearly approaching the Egyptian ( $A$. fasizata) : they certainly possessed the irascible qualities so distinctive of the Egyptians, and used their stilettoes unmercifully on some of the gentlemen connected with the show. We have not been sufficiently enamoured of them to pursue their cultivation further. The resemblance is so close to those bees already domiciled here that we see no special advantage to be gained by doing so.

7. Asiatic Bees. - This bee (Apis dorsata) is a distinct species; it is larger than our own, and exists in a wild state in the woods of India. Mr. Woodbury made considerable exertions to have a colony brought to England, but without success. The stings of these bees are more formidable than those of the varieties possessed here, and except as a matter of curiosity we can see nothing to recommend their introduction.

8. Egyptian Bees.-These bees, though called Apis fasciata, are considered by many as a variety of the same species as ordinary bees. They are rather smaller and slenderer than our own and the Italian, though closely resembling the latter in appearance. They have white hairs all about them, and the first two and a half rings of the abdomen are of a reddish yellow. The drones are also well marked with similar rings, and the queen is even more beautiful than the Italian. Baron von Berlepsch recommends crossing the handsomest Italian 
queens with Egyptian drones, with a view solely to the rsthetic purpose of raising the most beautiful breed of bees to be obtained.

The German apiarian Herr Vogel has given special attention to this varjety, and has discovered in it some interesting peculiarities.' It never gathers propolis, but uses wax in its place; and it seems almost proof against the cold. But the most singular fact that has come to his knowledge is that there exist regularly in an Egyptian colony some twelve or so small drone-laying queens, which would be called fertile workers but that they have a distinctive appearance, consisting in the waxen yellow of their breasts-a feature which is possessed also by the drones of their progeny. This is assuredly one of the most curious discoveries that have ever been made in relation even to this most curious of insects.

The late Mr. Woodbury imported some of these bees, but found them exceedingly vicious, and really to possess no superiority over our English bees. Some years since Mr. Waterhouse Hawkins, the naturalist, bought a stock of Mr. Woodbury, and brought them with him in order to place in the Horticultural Gardens at South Kensington. Being unacquainted with the placing of bees, he asked our aid in doing so. From the experience of them thereby acquired our own idea would be that no one conld ever desire such bees; they came out with a rush, and stung everybody within reach, right and left, who was 
not provided with a veil.* This is the kind of bee found in Palestine, and therefore the one which Samson found in the carcase of the lion.

In connection with this species, the Rev. H. B. Tristram, in his valuable book, "The Land of Israel," has an interesting account of the bees in that country. In Palestine bee-keeping is an important item of industry, and every house has a pile of beehives in its yard. Their bee, he says, "is amazingly abundant, both in hives, in rocks, and in old hollow trees. It is smaller than our ordinary bees, with brighter yellow bands on the thorax and abdomen, which is rather wasp-like in shape, and with very long antennæ. In its habits, and especially in the immense population of neuters in each community, and in the drones cast forth in autumn, it resembles the other species. Its sting also is quite as sharp. The hives are very simple, consisting of large tubes of sun-dried mud, like gas-pipes, about four feet long, and closed with mud at each end, leaving only an aperture in the centre large enough for two or three bees to pass at a time. The insects appear to frequent both doors equally. The tubes are laid in rows horizontally, and piled in a pyramid. I counted one of these colonies, consisting of seventy-eight tubes, each a distinct hive. Coolness being the great object, the whole is thickly

* Vogel says, that this bee never stings unless incensed, "but then quite maliciously ;" also that it is only more irritated by tobacco smoke, but is effectually subdued by that from willow touchwood. 
plastered over with mud and covered with boughs, while a branch is stuck in the ground at each end to assist the bees in alighting. At first we took these singular structures for ovens or hen-houses. The barbarous practice of destroying the swarms for their honey is unknown. When the hives are full the clay is removed from the ends of the pipes, and the honey extracted with an iron hook; those pieces of comb which contain young bees being carefully replaced, and the hives then closed up again. Everywhere during our journey we found honey was always to be purchased; and it is used by the natives for many culinary purposes, and especially for the preparation of sweet cakes. It has the delicate aromatic flavour of the thyme-scented honey of $\mathrm{Hybla}$ or Hymettus.

"But, however extensive are the bee colonies of the villages, the number of wild bees of the same species is far greater. The innumerable fissures and clefts of the limestone rocks, which everywhere flank the valleys, afford in their recesses secure shelter for any number of swarms; and rnany of the Bedouin, particularly in the wilderness of Judæa, obtain their subsistence by beehunting, bringing into Jerusalem jars of that wild honey on which John the Baptist fed in the wilderness, and which Jonathan had long before unwittingly tasted, when the comb had dropped on the ground from the hollow tree in which it was suspended. 'The visitor to the Wady Kurn, when he sees the busy multitudes of bees 
about its cliffs, cannot but racall to mind the promise, 'With honey out of the stony rock would I have satisfied thee.' There is no epithet of the Land of Promise more true to the letter, even to the present day, than this, that it was ' $a$ land flowing with milk and honey." "

The question as to the worth or worthlessness of the above respective varieties is not yet so decided a matter as it is with the Italians. Those interested in the sale of a particular race will praise it up, while those who have had a single disappointment with it will run it down-and that is nearly the sum of the experience to be gathered from current literature. Thus we find Dathe announcing, "I have discontinued the rearing of Cyprian, Egyptian, and Carniolan bees." That is intelligible; but in the same paper we read, "Between the German and Heath bees there is no particular difference"-which so staggers us after Von Berlepsch's wituperations of the latter that we do not know how much confidence we ought to place in the rest of the sentence, which is given as the summing up of a discussion in that famous bee country, Silesia: "The Egyptian bee ranks after the German and Italian; the Carniolan, at the expense of honey, produces many bees; the Cyprians are diligent, but quite inclined to sting. The Herzegovinian bee is praised. Bees obtained by judicious crossing have the preference over the pure races." 
Numbers of other varieties may be expected to crop up from time to time, as for instance the one last named. Della Rocca in the last century spoke of a "clawncoloured" bee that was brought from Holland and Belgium, and which is probably one of the races included with the Italian. Dr. Gerstäcker thus classifies the varieties: The North European (now spread all over the world), the Italian with black breasts, the Italian with yellow breasts, the Egyptian, the African, and the Madagascar. Three South Asiatic bees he regards as specifically distinct-Apis dorsata, indica, and florea. Mr. F. Smith adds zonata and nigrocincta, and inclines to make a species of fasciata (the Egyptians).

\section{§ VII. FACULTIES AND FUNCTIONS.}

It would be trenching too much upon our limits if we were to venture into the inviting field to which this heading might introduce us. Still the extreme interest of the subject renders it perhaps desirable that some succinct allusion should be made to it, even if it be for little more than to remark that the information we have to give is scattered through other sections and chapters. Especially as some might be disposed to skip the unattractive portion on "Anatomy and Physiology," it may be well to state here that in the second section of that chapter will be found a brief account of the sight and other senses of bees, and of the uses of their antennæ, by which they seem to feel, hear, smell, and communicate. 
A remark upon their power of distinguishing colours, and its practical value, will be found in connection with our description of bee-houses for twelve hives (Chap. IV. $\S$ i.). On the senses of taste and smell we have some further observations in the sections of Chapter VI. upon "Stings," "Robbing," and "Bee-keeping in London."

For the functions and habits of bees we must also refer to the passages already instanced, as well as to the sections above on the "The Queen," etc., that on "The Rationale of Swarming" (page 72), and to those in Chapter VI. on the four substances which bees collect or secrete, as well as (though in a less degree) to those headed "Pasturage" and "General Remarks." Those who will favour our book with a consecutive reading will, we trust, find at the conclusion that all the more impor-. tant and interesting facts of this class are in one or other of these places tolerably though briefly described.

The service that bees perform to flowers is a subject that has attracted much attention of late years. As every one knows, or should know, a flower has its stamens and pistils, which are respectively its male and female organs, and the pollen contained in the anthers, or little knobs on the summits of the stamens, must be conveyed to the pistils, or no seed will be produced. When the anthers burst; the pollen might happen to fall partly on the pistils, or it might not; but the visits of bees (though they do not roll about in the flower, in the manner that some have stated) are found by experience 
to be efficacious in conveying this dust to the right spot. Owners of fruit trees have noticed, in a season generally unfavourable to the orchard, that if during only one fine forenoon the bees had spread freely amongst the blossoms of a particular tree, that tree would prove more fruitful than its fellows. On this account the orchard is a good place for the apiary, for it seems that the more abundant the honey the better will be the crop of fruit. The whole subject is scientifically treated in Mr. Darwin's remarkable book, "The Fertilisation of Orchids," but we must add to the foregoing how much more urgent are the services of bees in the case of what are termed monocious and diccious plants, the former of which have the stamens and pistils in different flowers, and the latter have these flowers upon different roots. A familiar example of the former is found in the nut tree, whose long catkins, hanging like caterpillars in the early spring, are assemblages of male flowers; while the females, from which the nuts develop, may be detected by their crimson pistil-tips (stigmas), and grow in stalkless clusters of two or three in the openings of remote scaly buds. But for the visits or bees, our autumn nutting rambles would thus have but little prospect of success. In the second case, often very considerable distances intervene between the two flowers; for instance, with the common dog mercury (Mercurialis perennis), a botanist may find plantation after plantation containing male flowers by thousands, but not a single 
female; and at length in some far-off spot he may succeed in finding the females, equally by themselves, yet in full seed. In these cases there is nothing but the visits of pollen-gathering insects which can convey the fertilising dust to the flower for which it is designed. And according to Mr. Darwin all plants are practically diœcious, for he states that the pollen, to have a fertilising effect, must be brought to the pistils of one flower from the stamens of one on another root. Whether this be considered established or not, there remains the fact of the existence of diøcious plants as explaining the admirable design of the provision that a bee in the course of one flight shall gather pollen solely from one species. As far as honey-gathering is concerned the bee is not governed by this rule; but for this other important function it becomes absolutely essential that the right pollen, and that only, should be conveyed to the right flower. The careful observer may note how the dust on the bodies of bees varies from yellow to red and brown according to the kind of flowers from which it has been gathered, and the "socks," as the Germans call them, on the two hind legs will be found always of the same colour.

To no scientific man are we probably more indebted for observations and deductions upon this branch than to Sir John Lubbock. Whilst this edition was in course of preparation it was the writer's privilege to listen to a lecture upon "Relations of Plants and Insects" delivered by this able investigator before the Society 
of Arts; and the lecture has since been published as a paper in the Fortnightly Review of April 1877. In the course of his remarks Sir John cited many interesting particulars of the ways in which flowers are protected from the incursions of ants, whose visits would be harmful, both from their rifling the stores from the bees, by whom alone they are likely to be fertilised, and from the liability of the latter to desert any species in which their tender probosces were in danger of being seized by ants-it being the nature of an ant to grapple any pointed thing directed towards her. Kerner was referred to as having observed some of the modes by which such results are obviated. In some cases there are chevaux de frise around the flower, in the form of hairs pointing downwards, or other barriers which the ant cannot penetrate or surmount : notably in the corn bluebottle, which is smooth all over except just beneath the 'flower, and' in the thicket heads of some thistles. In others there are glutinous parts which the ant cannot traverse, as was noticed in the Polygonum amphibium, which, when it. grows on land, has sticky glands at the extremities of certain hairs, while when in the water, where it is safe already, it is perfectly smooth. Again, there are pendulous flowers, like the snowdrop, which are so slippery on the surface that an ant would immediately slide off, as was humorously illustrated by a sketch prepared with. several others by the lecturer's daughter. Facts were also stated showing how the pollen is sometimes pre- 
served by the closing of certain flowers at times when winged insects were not on the move, and the exclusion thereby of such as would not aid in the work of fructifi. cation. "It is not too much to say," as Sir John elsewhere expresses himself ("British Wild Flowers in Relation to Insects"), "that if on the one hand flowers are in many cases necessary to insects, insects on the other hand are still more necessary to the very existence of flowers; that if insects have been in many cases modified and adapted with a view to obtain honey and pollen from flowers, flowers in their turn owe their scent and colour, their honey, and even their distinctive forms, to the action of insects."

\section{"And plains sad Chloris how these spoilers steal From her ripe crests the vivifying meal, Pare the thin films that shield her anthered reign, And all her nectared cells insatiate drain? No! kind intruders; all reserved for you She pours through honeyed horn her luscious dew, While, grateful for the rich repast, ye shed Fresh showers prolific round her genial bed."}

Evans.

\section{§ VIII. EGGS AND TRANSFORMATIONS.}

It is necessary that some explanation should be given, as to the existence of the bee before it emerges from the cell.

The eggs (Plate II. Fig. 7) of all the three kinds of bees, when first deposited, are of an oval shape, slightly. 
curved, and of a bluish-white colour. They are glutinous on the surface when laid, which causes them to adhere to the bases of the cells where the queen deposits them. In three or four days the egg changes to a small. white worm, and in this stage is known by the names of larva or grub (Plate II. Fig. 8), in which state it remains four to six days more-a drone six and a half; its dimensions enlarge during this period till it appears as a ring at the base of the cell. While in this stage it is fed by the nurse bees with a mixture of farina and honey, a transparent white fluid in which the larva floats, and the supply of which is so exactly apportioned that not a drop remains on its ceasing to be required.

The next transformation is to the nymph or pupa form. The nurse bees now seal up the cells with a preparation similar to wax, leaving them with coverings which, by their greater convexity and darker colour, distinguish them readily from honey cells. The pupa then spins round itself a film or cocoon, just as a silkworm does in its chrysalis state: workers and drones occupy thirty-six hours with this process; princesses, which spin only half-cocoons, finish them in twenty-four. The microscope shows that this cradle-curtain is perforated with very minute holes, through which the baby bee is duly supplied with air. No further attention on the part of the bees is now requisite, except a proper degree of heat, which they take care to keep up-a position for the breeding cells being selected in the centre of the hive, 
where the temperature is likely to be most congenial. The cells destined for the rearing of drones are larger than those from which workers will proceed, the former standing nineteen to the square inch against twentyseven of the latter: the former are also one-third as deep again as the latter, and are made slightly more convex when sealed over. But between the eggs themselves there is externally no difference whatever.

In from nineteen to twenty-one days after the egg is first laid (unless cold weather should have retarded it) the bee quits the pupa state, and, nibbling its way through the waxen covering that has enclosed it, comes forth a winged insect. The eggs of drones require twenty-four or twenty-five days, and those of queens sixteen or seventeen, to arrive at maturity. In the unicomb observatory hives the young bees may distinctly be seen as they literally tight their way into the world, for the other bees do not take the slightest notice, nor afford them any assistance. We have frequently been amused in watching the eager little new comer, now obtruding its head, and anon compelled to withdraw into the cell to escape being trampled on by the apparently unfeeling throng, until at last it has succeeded in making its exit. The little grey creature, after brushing and shaking itself, enters upon its duties in the hive, and after a while issues forth to the more laborious occupation of gathering honey in the fields-thus early illustrating that character for industry which has been proverbial at least since the 
days of Aristotle, and which has in our day been rendered familiar even to infant minds through the nursery rhymes of Dr. Watts.

\section{§ IX. REPRODUCTIVE ECONOMY.}

The fertilisation of the queen and the determination of the sexes of her progeny are two subjects of so much interest that we must make room for some exposition of the discoveries of the past thirty years in relation thereto. What has been already stated on the former of these under the section on "The Drone" consists of facts which were mainly established by Huber; but within the present generation the great German apiarians have returned to the question, and Dzierzon has set forth some most marvellous deductions, which Baron von Berlepsch has followed up with amplification and further proof. It was found that the queen while in a virgin condition was often capable of depositing eggs, and that these eggs, unlike those of poultry laid under somewhat similar conditions, would hatch equally with others, but they all produced drones. From this arose the question, Whence come the drones after the queen has been fertilised? A fact known from the days of Huber and Riem was by some supposed to settle the difficulty. In many hives there exist what are called "fertile workers"bees having the female organs sufficiently developed to deposit eggs, but not sufficiently so to receive fecundation; and as it was found that the eggs of these ful. 
filled the conditions required, and invariably produced drone bees, the theory was erected that these fertile workers were the regular producers of that sex. But this plausible solution of the problem did not stand examination. Every fertile queen does habitually lay eggs in drone cells, and from those eggs drones are uniformly developed. Dissection and microscopic analysis had therefore to be resorted to, and the course of investigation commenced by Swammerdam and pursued by Mlle. Jurine was now pushed to a much further extent.

Proceeding from the two ovaries of the queen there are two canals, called oviducts, which presently unite, and immediately beyond their point of juncture is a small globular receptacle which is called the spermatheca. With fertile queens it was found that this appendage is permanently occupied by a fluid identical with that in the reproductive organs of the drones, and that as such it abounds in spermatozoa; while with a virgin queen the fluid is totally destitute of these, and is wholly different in appearance, being thin and transparent. From this discovery the conclusion followed that each egg, as it passes down the oviduct and over the mouth of the spermatheca, may either receive fecundation or not, according as the queen's own will or some other circumstance shall determine. Dzierzon accordingly propounded as the apparent, though still only hypothetical, solution of the enigma, what is known as the doctrine 
of parthenogenesis or virgin breeding一the law that life is imparted by the mother independently, and that every egg as originally developed in her ovaries is of the male sex, but that whenever fertilised with the male fluid it becomes transformed into a female!

To convert this hypothesis into a demonstration, Von Berlepsch invited to his apiary in succession the two great comparative anatomists Professors Leuckart and Von Siebold, and furnished each with a number of both drone and worker eggs for microscopic examination. Leuckart examined the surfaces of the eggs; Von Siebold, who followed him, tried the interiors, and the latter by this means was triumphantly successful, for, after the most careful preparation of his subjects, he detected in thirty out of forty worker eggs from one to four spermatozoa apiece, while in his twenty-four drone eggs he found not a single one. The exceptions were insufficient to invalidate the results, for the ten worker eggs in which no signs of impregnation were found were only the failures of observation to be naturally expected in so delicate a scrutiny. Thus the fact was established that eggs which produce male bees are descended from the female only -in other words, that drones have no fathers !

Most strikingly has this law been corroborated by a discovery which we owe to the introduction of the Italian bee - a discovery, too, which any bee-keeper can make for himself. If an Italian queen is crossed with an English drone, or zice rersa, the workers only of her 
progeny will be mongrels-the drones will invariably retain the pure blood of the queen, thus proving to demonstration that they owe their origin to her alone. Should a mongrel drone be then observed, it will be a sure sign that a fertile worker is in the hive: the queen will not be its mother. Dr. Dönhoff, we are told, confirmed the same law by a converse method, having in 1855 obtained a worker bee from a drone egg which he had artificially impregnated with the male fluid.

The queen, as we have observed, is capable before fertilisation of becoming the mother of drones, but it is believed by some that if she has once commenced drone-laying it is impossible for her to become subsequently fertilised. Mr. Langstroth, however, mentions an instance to the contrary, where a queen of his, after persistently laying drone eggs for a week or two, became after that the happy mother of a thriving colony of workers. Von Berlepsch alludes to this case (with others like it), but is unconvinced, being suspicious that here again it was a fertile worker and not the queen who laid the drone eggs. But looking to the fact that many permanently unfertile queens lay drone eggs, while others lay no eggs at all, does it not seem reasonable that a similar difference may subsist previous to fecundation? Thus, while the Baron is on firm ground as to the general rule, we incline to a belief that as to the exception the American observer is quite correct.

Dzierzon thus writes: "In general, so long as the 
young queen continues her wedding flights-which in the warm summer she does at the very most for four weeks, but in the cool spring or autumn, when life and development are slower in the hive, she still pursues for even five or six weeks-she is capable of becoming properly fertile." But some queens continue to fly long after it is hopeless, cases being recorded in which they have gone on for ten or twelve weeks. The same observer speaks of having had several young queens which were either lame in their wings or born in a continued cold season, so that they were prevented from leaving the hive, and thus developed into confirmed drone-breeders. The queen leaves the hive every fine day till her purpose is accomplished, and this led Bevan and others to surmise that she met successively with several drones till one of them lost his life in consequence; but we do not find in later authorities any confirmation nor even mention of this conjecture, and it may be set down as entirely improbable. In the case observed by Von Klipstein, and referred to above (page 22 ), as the queen met with her death shortly after, he sent her to Leuckart, who found that from this obviously first impregnation her organs were so completely filled as to imply no need for a second. Leuckart has elsewhere stated that a queen's spermatheca is capable of containing twenty-five millions of spermatozoa, so that there need be no wonder at the fact of a single fecundation being sufficient to answer for her entire term of existence. 
The fertile workers, which by their course of adding to. the drone stock may prove a terrible nuisance in a hive, were ascertained by Huber to be always hatched in close proximity to the queen cells, whence he conjectured that they obtained by accident a portion of the royal jelly designed for the rearing of princesses. Von Berlepsch and Langstroth prefer the theory that such jelly was purposely given them, and the conversion of their own cells into royal ones commenced, but that the intention was afterwards abandoned, as it is known that bees often. start more of such cells than they ultimately proceed with. They are of only exceptional occurrence in hives in a normal condition, but in a queenless stock they very often appear, sometimes even in considerable numbers, having been probably fostered with the jelly, but at too late a period to convert them into queens. They usually deposit their eggs correctly in drone cells, though dronebreeding queens lay in those of workers and even in royal cells-thus evincing a presence of the will though an absence of the power. To get rid of a fertile worker it has been recommended by Mr. Rorl to "drive" the bees (Chap. V. § iv.) to an empty hive, and place this in a near spot; all will return to their old home except the one to be got rid of, she having probably never flown before, and therefore not knowing her way.

\section{$\S$ X. RELATION OF SEX TO CELLS.}

. There remains the very interesting question of the 
connection between sex and cells, which, if it be not paradoxical to say so, is as a general rule invariable; that is to say, when both the queen and the hive are in a normal condition, the eggs laid in each class of cells produce respectively workers and drones without failure or exception. But in abnormal circumstances, as with a drone-breeding queen, the law does not hold, and drones of a diminished size are hatched from worker cells, though the bees, on discovering the state of things, do their best by subsequent elongation to adapt the cradles to their unexpected occupants. Such is the explanation of the existence of "small drones;" but workers hatched in drone cells do not appear to be in any way peculiar. In regard then to the main fact we are confronted with the question, Has the queen a knowledge, at the moment of laying, of the gender of each particular egg ? Rather, it would seem, she has the power of making it what gender she pleases by compressing her spermatheca or not at the instant of its passing down her oviduct. We must however refer to an ingenious theory to the contrary, quoted by Langstroth as started by his friend the late Mr. Wagner of Philadelphia, and which has been approved by many in this country and Germany also. It is to the effect that not the queen's own will, but the narrow limits of the worker cells, administer the above compression, while the more spacious drone cells allow her body to be inserted without such effect. Von Berlepsch however, it is safe to say, has absolutely 
demolished this mechanical explanation; and as some recent writers have quoted the. "Wagner theory" with approval, it may be best to give the German observer's principal objections in his own words :-

"This explanation is thoroughly untenable; for(a) perfectly new worker cells are fully as wide as very old drone cells in which breeding has taken place many times, and yet, as found by experience, female bees come from the former and males from the latter. (b) Many queens are of a strikingly slender form, some of them occasionally so small that they can scarcely be distinguished from workers, and yet they have no proclivity to drone-laying-which must however have been the case if the narrow cell effected the fertilisation of the egg by pressure. ... (c) A queen lays even in cells that are scarcely begun, with which, therefore, the proportion of the diameter to the thickness of her body can exercise no influence at all, and yet drones come forth from the drone cells and workers from the worker cells. (d) If there are no drone cells at her command, and the stock is in want of drones, the queen lays male eggs in worker cells, and drones hatch from them. . . (i) A fertile queen, if introduced with her colony into a hive containing nothing but drone comb, would naturally [on such hypothesis] furnish the drone cells with eggs as she would worker cells, and make no difficulty about it. But she does make a very great difficulty-for a long time she lays no eggs in the cells at all, but lets them drop, or 
tries to escape abroad with her entire colony. But at last she does lay in the drone cells, and what ensues? Ordinary worker bees come forth." Instances follow of experiments decisively proving this. It is only fair, however, to add that Mr. Wagner's theory does not necessarily degrade the monarch of the hive into "a mere egg-laying máchine," as Von Berlepsch regards it in some of his arguments, for she might still exhibit intelligence in deciding which cells to lay in, even if the determination of the sex of the egg rested finally with the cell which she had chosen.

The queen then exercises a personal control over each egg as she deposits it, but, unless interfered with by irregular circumstances, she adapts her will to the cells and chooses the cells according to the requirements of the hive. But when both drones and workers are in requisition she lays her eggs in each class of cells just as she comes to them, as to which fact the Baron gives abundant evidence, having in one instance observed a queen make no fewer than five changes in a day from worker to drone cells or vice versa without any intermission. Inconșistent as it may appear, she also herself deposits in royal cells the eggs which are to hatch into her rivals -that is, when these cells have been prepared with a view to swarming-for the preponderance of argument goes against the belief that eggs are ever removed into these by the workers.* In addition to determining the * The eggs when once deposited adhere to the cells and could 
sex she is further capable of regulating to a large extent the total number of eggs she lays, and thus of modifying the growth of the population with the character of the season and the condition of the colony: thus a queen that has been transferred from a weak to a strong hive has been know to vary in two or three days from no eggs at all to two thousand a day. She lays during some ten months of the year, suspending the process in November and December. For her first season she lays almost exclusively worker eggs.

We are told of the occasional occurrence of hermaphrodite bees, half workers and half drones, and the explanation of their existence is given by Von Berlepsch as an incomplete penetration of the shell of the egg, in the act of fertilising, by the spermatozoa. Yet another order of individuals has been supposed to exist by some, and they have termed them "black bees," * also "drone mothers;" they are not, however, the veritable "fertile workers" named above, but owe their distinction solely to misconception. They are blacker than the rest, and often with fewer and shorter hairs; but the above author, after ascertaining from Leuckart that there was no anato.

not be removed without ruining them ; but accasionally when fresh laid they stick to the body of the queen, or even of a worker. Queenless stocks sometimes in their temporary insanity start new queen cells without thinking where the eggs are to come from; but these will remain empty unless some fertile worker'tries her skill.

* This term is also sometimes applied to English bees generally in distinction from the Italians. 
mical difference, proved by experiments that their colour was caused simply by smearing with honey, or else was the effect of stifling or of fright, and that the loss of hairs was owing to nothing more than having crept repeatedly through confined entrance-holes! Similarly Dzierzon: "The black colour is one purely accidental, produced through heating, rubbing against sides, biting, smearing, licking, and the like. As a rule, the glossy black bees are robbers which have been pursuing their trade for some considerable time."

$\S$ XI. THE RATIONALE OF SWARMING.

Under this heading we purpose to describe such matters as belong chiefly to the natural history of the bee, thus reserving for its proper position at the beginning of our fifth chapter all which strictly belongs to the subject of "Manipulation," and which it is to the convenience of the inexperienced bee-keeper to find brief and ready to his hand at any moment of emergency. A leisurely digesting of the interesting facts stated in the present section will, however, greatly assist him in the intelligent following of his pursuit.

In May, when the preceding part of the spring has been fine, the queen bee is very active in the deposition of eggs, and the increase in a strong healthy hive is so prodigious that emigration is necessary, or work would soon cease. The bees, on arriving at a conviction of this fact, commence preparations by the building of royal 
cells, thus putting matters straight for the after government and progress of the hive. The queen, nolens zolens, falls in with the general resolution, and makes off with the swarm on the first pleasant day after one of these cells has been sealed over, that is to say, some six or seven days before her first rival is likely to emerge. If delayed by the weather till within two days of the hatching of this, the bees usually destroy all the princesses, and either start fresh cells or give up swarming altogether for the season. It is now a well-established fact that the old queen goes forth with the first swarm, and thus the sovereignty of the old hive devolves upon a young queen. Dzierzon, however, once met with a case in which the old queen refused to stir, and three strong swarms were led forth by young princesses in the course of five days. By the bye, it should be added that swarms are never "led" forth except by young queens, in the sense of having these at their head; fruitful mothers usually follow in the midst.

As soon as the swarm builds combs in its new abode, the emigrant queen beyins laying eggs in the cells, and thereby speedily multiplies the labourers of the new colony. Although there is now amongst apiarians no doubt that the old queen quits her home, there is no rule as to the composition of the swarm : old and young alike depart. Some show unmistakable signs of age by their ragged wings, others their extreme youth by their lighter colour. We do not, however, use the term "young" in 
reference to those youngest inhabitants of the hive whose engagements are solely within doors, for these cannot go till their proper time for flying has arrived. Von Berlepsch says that all the adult bees which are at home at the time of starting go with the swarm; and sometimes this results in none but the brood bees being left-or only one-fourth of the population. In preparation for flight, bees commence filling their honey-bags, taking sufficient, it is said, for three days' sustenance. This store is needful, not only for food, but to enable them to commence the secretion of wax and the building of combs in their new domicile.

On the day of emigration the weather must be fine, warm, and clear, with but little wind stirring; for the old queen, like a prudent matron, will not venture out unless the day is in every way favourable. Whilst her majesty hesitates, either for the reasons we have mentioned or because the internal arrangements are not sufficiently matured, the bees will often fly about or hang in clusters at the entrance of the hive for two or three days and nights together, all labour meanwhile being apparently suspended. When this cluster is formed in the morning hours, and grows constantly larger in spite of the sun, it may be taken as the sign of a very speedy start. The busy flitting of other bees around this cluster, or their sporting in numbers before the hive, are also reliable signs, and some have included the appearance of drones at ten in the morning. At the last, when the time is 
quite fixed, the bees in the cluster suddenly return to the hive to fill themselves with honey for the flight. The agitation of the little folk is well described by Evans :-

"See where, with hurried step, the impassioned throng

Pace o'er the hive, and seem, with plaintive song,

To invite their loitering queen; now range the floor,

And hang in clustered columns from the door;

Or now in restless rings around they fly,

Nor spoil they sip, nor load the hollowed thigh ;

E'en the dull drone his wonted ease gives o'er,

Flaps the unwieldy wing, and longs to soar."

But when all is ready, a scene of the most violent agitation takes place; the bees rush out in vast numbers, forming quite a dark cloud as they traverse the air.

The time selected for the departure of the emigrants is generally between ro a.m. and 3 p.m.; most swarms come off within an hour of noon. ' In very sultry weather they have been known to be as early as 7 a.m., and on the other hand as late as 5 p.m., though this last probably only occurs when a young queen leads the detachment. As a rule, says Von Berlepsch, first swarms start in the morning and after-swarms in the afternoon. It is a very general remark that bees choose a Sunday for swarming, and probably this is because then greater stillness reigns around. It will not be difficult to imagine that the careful bee-keeper is anxious to keep a strict watch, lest he should lose such a treasure when once it takes wing. The exciting scene at a bee-swarming has been well described by the apiatian laureate :- 
"Mounts the glad chief! and, to the cheated eye, Ten thoưsand"shuttles dart along the sky, As swift through ether rise the rushing swarms, Gay dancing to the beam their sun-bright forms, And each thin form, still lingering on the sight, Trails, as it shoots, a line of silver light.

High poised on buoyant wing, the thoughtful queen

In gaze attentive views the varied scene, And soon her far-stretched ken discerns below The light laburnum lift her polished brow, Wave her green leafy ringlets o'er the glade, And seem to beckon to her friendly shade. Swift as the falcon's sweep, the monarch bends Her flight abrupt : the following host descends; Round the fine twig, like clustered grapes, they close In thickening wreaths, and court a short repose."

As it often happens with after-swarms that more than one young queen is hatched before the start is made, the presence of these may cause irregular and puzzling behaviour in 'the bees. Langstroth mentions a case in which no less than eight queens must have started thus together, and Von Berlepsch once met with the same number; while Spitzner found a swarm with so many as twenty-one, but this happened fourteen days after the return to the hive of the first swarm, which had lost its queen. As mentioned in the section on "The Queen," it is not altogether a rare occurrence, though certainly the exception, for more than one monarch to settle down together. In one American case no fewer than five colonies once took up their quarters in a single large 
box, and remained there through a season "united yet divided."

If, on the contrary, the queen is not in the swarm at all, the bees sometimes return at once to the hive, and sometimes they first institute a search for her majesty. In the famous but cruel experiment of Dr. Warder a whole swarm was starved to death by alternate deprivations and restorations of their queen repeated at intervals during five days. Of course in his day this devotion was attributed to personal regard.

Exceptional cases of another kind are also not uncommon, in which a colony has made no preparation for swarming (by the formation of royal cells), but on the sudden arrival of warm weather it is enticed-Dzierzon says by the heat itself, Von Berlepsch by the contagious example of neighbouring hives - to carry out in a hurry that which ought to have received some ten days' preliminary care. "An internal revolution is made," says the Baron, "and they rush forth for the swarm. The queen, as becomes the pseudo-sovereign of a democratic monarchy, hastens to prove to her people their most. obedient servant, and there the swarm is, hanging on the first convenient tree." On the following morning it will in such case be found that worker cells have been transformed into royal ones.

An instance illustrating the way in which bees sometimes make provision beforehand of a place to fly to when about to swarm came under oiur own notice a few years 
since. A lady who lived about a quarter of a mile from our apiary sent to us to say that a swarm had gone in at a hole over her stable, and to ask us to come and hive them. On our going to do so her gardener told us that he had seen three days previous two or three bees as if reconnoitring; next day several came, and about eleven o'clock on the third day the whole swarm went in and took up their position between the rafters under the flooring. The difficulty was now to get at them. A carpenter was sent for, the boards were taken up, a hive was set over, with a brood comb placed in it to attract them, and by dint of smoke and brushing with a feather, the queen and her retinue were coaxed to ascend into the hive. Some of the bees had already gone out to forage, and there were many flying about that had not settled; so to secure these and make it easy for them, we brought the hive out, and erected a sort of platform on a pair of steps close to the hole, which we stopped. By nighttime all the out-flying bees had joined the swarm and were easily removed.

We ought to mention that we recognised this swarm from the appearance of the bees as those from the Carniolan hive left under our care by the Rev. W. C. Cotton (page 45), and as the queen with the swarm was the original, we had to ask that we might be allowed to take the bees back if we provided a swarm of the ordinary English bees, which offer was accepted. Mr. Cotton eventually took this colony to his residence at 
Frodsham near.Chester, and we kept the stock, which of course had a new queen. The bees did not long retain their distinctive features.

A swarm of bees, in a natural state, contains from ro,000 to 20,000 insects. . "On an average," says Dzierzon, "we may call 20,000 a strong swarm, I2,000 to $\mathrm{I} 5,000$ a moderate one, and 6,000 to 8,000 a weak one." Von Berlepsch by a very careful experiment estimated that there were 5,600 unloaded bees in a pound, so that when loaded for swarming there would certainly not be more than 4,000. A good swarm will therefore weigh from three to five pounds. We have known swarms not heavier than two pounds and a half that were in very excellent condition in August as regards store for the winter; though the Baron's experiments showed with remarkable conformity that for a new swarm six pounds was proportionally more profitable than any other weight, larger or smaller. For a fully furnished hive, he. states, there seems really no limit but that of space-the more bees the better.

Hitherto our remarks have had reference to first or "prime" swarms; these are the best, and when a swarm is purchased, such should be bargained for. But there are also second swarms, known amongst cottage beekeepers as "casts," one of which is often found to issue from the hive nine or ten days after the first has departed; in very rare cases such has been known as early as the third or as late as the seventeenth day. It is not always 
that a second swarm issues, as so much depends on the strength of the stock, the weather, and other causes; but should the bees determine to throw out another, the first hatched queen in the stock hive is prevented by her subjects from destroying the other royal princesses, as she would do if left to her own will. She in consequence becomes highly indignant; and, when thwarted in her purpose, utters, in quick succession, shrill angry sounds, much resembling Peep, peep, ${ }^{*}$ commonly called "piping," but which more courtly apiarians have styled the vox regalis. The princesses answer her in a somewhat different note-these being, it must be understood, by this time perfectly developed queens, but afraid to quit their cells, where accordingly the brood bees feed them.

This royal wailing continues during the evening, and is sometimes so loud as to be distinctly audible many yards from the hive. When this is the case, a swarm may usually be expected either on the next day or at latest within three days, unless the weather causes a longer postponement. This sound, when persevered in, is a sure sign of the issuing of an after-swarm, but it is in such case almost the only sign, and it must be noted that even when the bees do not intend to swarm it may sometimes be heard a day or two after a second swarm

* So all English writers. Bees in Germany evidently speak a different language, for there the reigning queen cries, Tïh, tïh, while her imprisoned rival answers, Quah, quah. 
has left. If not heard it may be concluded that swarming is at an end. The second swarm is not quite so chary of weather as the first; it was the old lady who exercised so much caution, disliking to leave home except in the best of summer weather.

In some instances, owing to favourable breeding sea sons and prolific queens, a third swarm issues from the hive (usually after intervals of two or three days), which is termed a "colt;" and in remarkable instances even a fourth (after another day's interval), which in rustic phrase is designated a "filly." Mr. Langstroth says that he once had a fifth, and all five in the course of a fortnight. A swarm from a swarm is called a "maiden" swarm, and, according to bee theory, will again have the old queen for its leader: if such does occur it will probably be at about a month after the hiving. The original colony, of one or more years' duration, is known as a "stock."

When swarming is over for the season any princesse remaining in cells are torn out and destroyed as beforc stated, or else left to the tender mercies of the reigning sovereign. But now and then one of them slips past her assailants, "and then," says Von Berlepsch, "there ensues a regular hunt, which I have several times observed through the hive window. The queen, well knowing the fate that is in store for her, rushes away, and the bees pursue; when seized by the feet or the wings she cries out pitiably, and one queen so moved my compassion 
that I liberated her, put her in a queen cage, supplied her with workers and comb on a following day, and, as she became successfully fertilised, brought her through the winter."

\section{§ XII. INCKEASE OF BEES.}

In the section upon "The Queen" we have given (page 10) some particulars as to the rate of breeding with bees. The needful expansion for this rapid development is found in the above process of "swarming," by which they provide themselves with fresh space, and plant new colonies. But the object of the bee-master is to train and educate his bees, and in so doing he avoids much of the risk and trouble which is incurred by allowing the busy folk to follow their own devices. The various methods for this end adopted by apiarians all come under the term of the "depriving" system, and they form part of the great object of humane and economical bee-keeping, which is to save the bees alive instead of slaughtering them as under the old clumsy régime. A very natural question is often asked: How is it that, upon the depriving system, where our object is to prevent swarming, the increase of numbers is not so great as upon the old plan? It will be seen that the laying of eggs is performed by the queen only, and that there is but one queen to each hive; so that where swarming is prevented there remains only one hive or stock, as the superfluous princesses are not allowed to come to 
maturity. If all those princesses were to become monarchs, or mother bees, and to emigrate with a proportionate number of workers, increase would be going on more rapidly; but the old stock would be so impoverished thereby as possibly to yield no surplus honey, whilst the swarms might come off too late for them to collect sufficient store whereon to grow populous enough to withstand the winter.

With bees, as with men, "union is strength;" and it is often better to induce them to remain as one family, rather than to part numbers at a late period of the honey-gathering season, without a prospect of supporting themselves, and so perish from cold and hunger during the ordeal of the winter season. This is one of the great secrets of successful bee-keeping. Mr. Langstroth's recommendation is that none "but the most experienced apiarians" should attempt "at the furthest to do more than treble their stocks in one year." Even doubling them, he says, is often too rapid an increase for obtaining spare honey.

Our plan of giving additional storage-room will, generally speaking, prevent swarming. This stay-at-home policy, we contend, is an advantage; for instead of the loss of time consequent upon a swarm hanging out preparatory to flight, all the bees are engaged in collecting honey, and that at a time when the weather is most favourable and the food most abundant. Upon the old system the swarm leaves the hive simply because the 
dwelling has not been enlarged at the time when the bees are increasing. Upon the antiquated and inhuman plan where so great a destruction takes place by the brimstone match, breeding must, of course, be allowed to go on to its full extent to make up for such sacrifices. Our chief object under the new system is to obtain honey free from all extraneous matter. No one can depend upon gathering pure honey from combs where storing and breeding are performed in the same compartment. For fuller explanations on this point we refer to the various descriptions of our improved hives in a subsequent chapter of this work.

We often receive from Scotland magnificent boxes of honey; and though the fine quality is no doubt to be in part attributed to good pasturage, it is largely owing to keeping the stocks strong, and thus having hives well stored and well populated early in the season. A weakly hive will take some weeks, if not months, to grow populous; and as soon as the strength of the hive has recovered, the honey season will have advanced, if not ended, whilst the strong stocks have been able to take full advantage of the supplies, having an abundance of labourers to collect the honey and store it in supers for their master.

There can now be scarcely two opinions as to the uselessness of the rustic plan of immolating the poor bees after they have striven through the summer so to "improve each shining hour." The ancients in Greece and 
Italy took the surplus honey and spared the bees, and now for every intelligent bee-keeper there are ample appliances wherewith to attain the same results. Mr. Langstroth quotes from the German the following epitaph, which, he says, "might be properly placed over every pit of brimstoned bees:"-

\title{
Wete lRests, \\ CUT OFF FROM USEFUL LABOUR, \\ A COLONY OF \\ INDUSTRIOUS BEES,
}

\author{
BASELY MURDERED \\ BY ITS \\ UNGRATEFUL AND IGNORANT \\ OWNER:
}

And Thomson, the poet of "The Seasons," has recorded an eloquent poetic protest against the barbarous practice, for which, however, in his day there was no alternative :-

"Ah ! see, where, robbed and murdered, in that pit Lies the still-heaving hive ! at evening snatched, Beneath the cloud of guilt-concealing night, And fixed o'er sulphur ; while, not dreaming ill, The happy people, in their waxen cells, Sat tending public cares, and planning schemes Of temperance, for winter poor ; rejoiced To mark, full flowing round, their copious stores. Sudden, the dark, oppressive steam ascends ; And, used to milder scents, the tender race By thousands tumble from their honeyed domes, Convolved and agonising in the dust."

It will be our pleasing task, in subsequent chapters; to show "a more excellent way." 


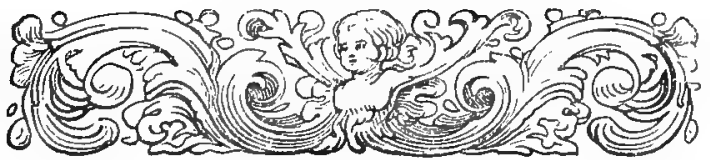

CHAPTER II.

ANATOMY AND PHYSIOLOGY.

§ I. PRELIMINARY REMARKS.

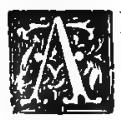

LTHOUGH the principal object in compiling the present work has been to induct our readers into the way of keeping bees according to the most recent and approved methods, it requires little apology for thus apparently deviating from such prescribed course by devoting a small portion of our space to a description of the anatomy of the wonderful little creatures whose labours all our contrivances are intended to assist, especially since a knowledge of their habits is not only interesting to the bee-keeper, but enables him to conduct his apiary in accordance therewith.

In a treatise of this kind, intended to be of a popular character, we shall endeavour to place these details before our readers in a concise and simple manner, avoiding as much as may be technical terms, and referring those who wish to go more deeply into this branch of the subject to the works of Kirby and Spence, Samuelson, 
etc. In the course of our descriptions we shall frequently refer to the steel engravings, Plates I. and II., drawn by Mr. E. W. Robinson, artist to the Entomological Society of London, who has most carefully dissected bees we sent him for the purpose, subjected these dissections to the microscope, and skilfully produced the accompanying illustrations, which will so much assist the purpose we have in view. These delineations are so clear that a little explanation will suffice to impart a full understanding of the various parts of the bee.

Because the bee is so small an insect we are not to neglect investigating its organisation. "The bee is little among such as fly, but her fruit is the chief of sweet things." The enlightened Boyle, when contemplating the wonders of Nature, declared that his astonishment had been more excited by the mite than by the elephant; and that his admiration dwelt "not so much on the clocks as on the watches of creation."*

The Figures I, 2, and 3, in Plate I., respectively represent the exterior forms of the queen, the worker, and the drone. They are thus coloured for the purpose of illustrating the Yellow Italian Alp, or Ligurian bee, now deservedly held in such high estimation by bee-keepers, and of whose good qualities we have already remarked. All the bees constituting a stock may not be of quite so bright a colour as those represented: the old bees differ in appearance from the younger ones-darkened bodies

* Dr. Bevan. 


\section{ANATOMY AND PHYSIOLOGY. [CH. II.}

and ragged wings, not grey hairs and wrinkled faces, are the signs of old age-so that with bees (especially Italians), as with the gentler sex of the human race, there is appointed a period both of youth and beauty.

The anatomical structure of our English bee is the same in kind as that of the Italian; * a description of the one will therefore serve for the other. The most apparent difference consists in the colour. The English bee is of a blackish brown; both varieties have their bodies wholly covered with close-set hairs. These hairs deserve particular attention, because, although so small, each hair is feather-shaped, consisting of a stem and branches somewhat analogous to the feathers of birds. This form is extremely serviceable to the insect, when revelling in the corolla of flowers, to collect the farina, and, besides being thus useful, is peculiarly adapted for retaining animal heat. $\dagger$

The insect is divided into three parts-the head, the thorax or chest, and the abdomen.

\section{THE HEAD AND ORGANS OF SENSATION.}

,The head of the queen (Plate I. Fig. I $c$ ), as also that of the drone (Fig. $3 \mathrm{c}$ ), is rounder than that of the worker bee. This last (Fig. $2 c$ ) is of a triangular shape, and

* Naturalists consider the Italian bee a very superior race, and that the various organs are stronger and of greater capacity; it is however not easy to define the precise anatomical superiority.

† "Naturalist's Library." 
Plate. 2.

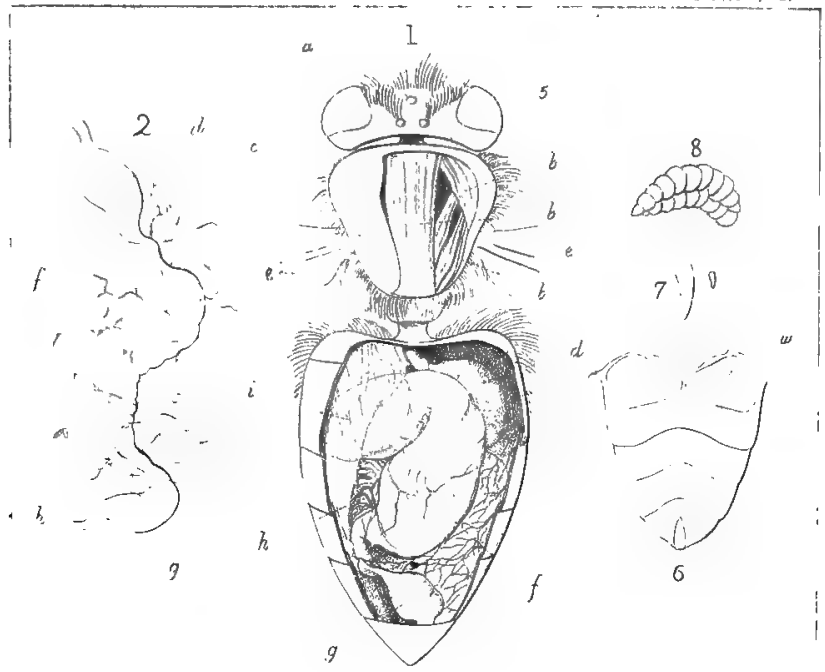

3
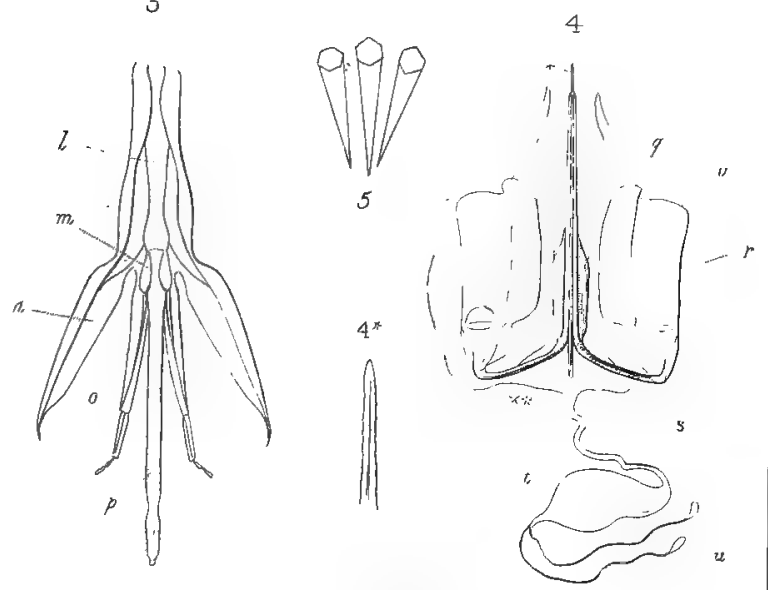



\section{\$II.] HEAD AND ORGANS OF SENSATION. 89}

much flattened, as in Fig. $2 c^{*}$, which shows the side view. In common with other creatures, the head contains the inlet for nutrition, and is the seat of the principal organs of sensation.

In the figures before alluded to may be seen the double visual apparatus with which bees are provided. The oval lobes on each side of the head represent the two eyes, the secondary organs of vision being the three small eyes on the top of the head, called "stemmata." We shall first describe the two larger eyes, which, as seems to be the case with all insects, are immovable, and have neither irides nor pupils, nor yet eyelids to cover them, but are protected from the dust or pollen of flowers by a number of small hairs, as well as by a horny tunicle, which defends and secures them from injury. The multitude of hexagonal lenses, called "ocelli," which make up the eye of a bee, give it, when viewed through a microscope, the appearance of honeycomb ; or we might compare it to a multiplying-glass with hexahedral facets, each facet representing the surface of one ocellus. But when we look also to the inner structure, it resembles rather some thousands of telescopes all converging towards one point. It has been computed that in each eye there are 3,500 of these collateral lenses. Fig. 5 in Plate II. represents three of these prisms or lenses magnified. Each of them is wonderfully intricate in structure, comprising, first two plano-convex lenses of different densities, fitted together on the flat sides on the principle of an 
achromatic object-glass; next an empty space surrounded with dark pigment, which is convex within like the neck of a vase, so as to narrow the passage for the rays to about one-half the diameter, or one-fourth the superficial space; and lastly a longer conical lens, convex at each end and communicating with the optic nerve. The simple eyes, or stemmata, on the contrary, are as strictly simple as their name implies, consisting of one nearly globular lens apiece.

The construction of the eye for seeing objects best at a moderate distance will account for the fact that bees mount high up into the air after collecting their store of food, and then, having determined the point, no matter how far off, they fly homewards with the directness of a cannon-ball, and alight at the door of their own habitation, though the country around may be crowded with hives; but on reaching the entrance their vision appears defective, for they then feel their way with the antennæ as if totally blind, and should the hive have been moved a little they will rise again into the air to obtain a more distant view, suited to the lengthened focus of their sight. When a stock or swarm is brought from a distance the bees do not take their departure at once, but reconnoitre awhile, visiting surrounding objects so as to well know the spot again in order to return thereto.

The distinct purposes of the two different kinds of eyes may not perhaps be yet determined with certainty, but Pastor Schönfeld (whom Von Berlepsch employs to 


\section{§II.] HEAD AND ORGANS OF SENSATION. 91}

write those sections of his own work that relate to the senses of bees, as being "beyond doubt the best-informed of apiarians on these subjects") gives a decided opinion that the stemmata serve only for the most distant objects, while the compound eyes, which are much more highly refractive, become available when closer at hand. Thus these eyes, which we compared to telescopes, are credited with the least of telescopic power, and serve for nearer observation after all. How much nearer, however, we are not yet in a position to say, and nothing need be withdrawn of what is stated above as to the far-sightedness of bees. The compound eyes are assumed to be also serviceable in the twilight, and thus to afford some vision in the interior of a hive. It is worth mentioning, as a rare compliment from a German to an English apiarian, that Schönfeld declares the best anatomical description of the eyes of our insect to be given by Samuelson in his work, "The Honey Bee."*

The mouth of the bee is a most complex structure, marvellously adapted for its duties, and consists of the labrum, or upper lip, with the mandibles, or upper gills, and of the labium, or lower lip, which is made up of the ligula or tongue, also called the proboscis, the labial palpi, and the paraglossa, together with the maxilla, or lower gills-we adopt this word "gills" from the German for want of a better. The jaws open vertically, but the

* The compliment belongs doultless to Dr. Hicks, to whom the anatomical portion of that work is presumably due. 
mandibles, maxillæ, and palpi work horizontally, and serve as pincers or scissors. The mandibles are the two side pieces which constitute the working portion of the upper jaw. Fig. I $d$ in Plate I. shows the mandible of the queen, which, like that of the drone (Fig. $3 d$ ), is provided with two teeth, whilst the mandible of the worker (Fig. $2 d$ ) is without teeth. This last having to manipulate the wax with smoothness, the teeth would doubtless be objectionable. These mandibles are strong, horny, and sharp-pointed, to assist in breaking down food, and in other respects constitute serviceable tools for seizing their enemies, ejecting the drones, etc.

The tongue (Plate II. Fig. 3), or proboscis, is a long slender projection, flattish in form, and about the thickness of a bristle. It has about forty cartilaginous rings, each of which is fringed with minute hairs, having also a small tuft of hair at its extremity, where it is somewhat șerrated. In movement it is like the trunk of an elephant, and is susceptible of extension and contraction, bending and twisting in all directions; and by rolling about, it sweeps or laps up, by means of the fringes around it, everything to which it is applied. Thus, when a bee alights upon a flower, it pierces the petals and stamens, where the nectar is secreted, and deposits its collection on the tongue, from whence it passes into the gullet (Plate I. Fig. $2 \mathrm{c}$ ) at its base. At times, in building combs, the tongue is used as a trowel, with which the minute scales of wax are deposited in their appropriate 
\$II.] HEAD AND ORGANS OF SENSATION. 93

places, and the desired finish is given to the cells. This organ has been denied by some to be a hollow tube, but this is not the view generally held, and it certainly does not act wholly by handing up the food, for there is a furrow or gutter running along the whole length of its under side. Thus, when a bee is imbibing honey the rings of the abdomen have a vibratory motion similar to pumping, showing to the casual observer that suction is rapidly going on. Dr. Bevan tells us that the true tongue is an extremely minute object at the base of the maxillæ; but this appears to have been a mistake of his own.

The labial palpi (Plate II. Fig. 30 ) rise from the base of each side of this lapping instrument, and are also ciliated exteriorly. They appear to serve as feelers to the mouth. Between these and the tongue are the two small sheaths or membranes called the paraglossæ; and outside of the same are the working portions of the lower jaw, or the maxillæ (Fig. $3 n$ ), which are also provided with hairs and with two feelers midway known as maxillary palpi. When the jaws close on the tongue they form a sheath or defence thereto.

With the mandibles of the upper jaw opening right and left, and the maxillæ of the lower, which serve to hold the object laboured upon, the insect prepares its work for the sweeping-up apparatus of the lower parts. Thus, when combs become mouldy, or in any way unfit receptacles for brood or honey, these tools provided by 
Nature serve the place of hands, and the bees are able to chop up in small pieces, and remove from their dwelling, whatever lumber of this kind may be offensive to them. They are applied also for opening the anthers of flowers. 'The whole of this apparatus, while perfect in action in an expanded state, can be folded or coiled together when not in use, so as to form one strong and well-protected instrument.

The antennæ (Plate I. Figs. I $a, 2 a, 3 a$ ) are most important instruments, and are planted between or below the eyes and a little below the stemmata, one on each side; they consist of a number of tubular joints, each having a separate motion, and, being thus jointed throughout their whole length, they are capable of every variety of flexure, and their extremities are exquisitely sensitive. With the antennæ these insects recognise their queen, and appear to communicate to each other their joys and sorrows. For instance, if a colony be deprived of its queen, bees may be seen rushing about the hive, and, with a nervous twinge, crossing their antennæ or violently striking them together, and conveying the intelligence of their forlorn state. The sense of touch is here most acute. Huber performed an interesting experiment which definitely proved that it was by means of these organs that they communicated with each other. Dividing a hive by a grating which kept the two portions too widely apart for the antennæ to meet, he soon had the queenless half in a state of commotion and upset; but when he allowed 


\section{§II.] HEAD AND ORGANS OF SENSATION. 95}

these feelers the means of access, though nothing else could be passed through, hẹ saw them by hundreds making their enquiries, and receiving answers, which resulted in the whole remaining tranquil. The same observer tried the experiment of depriving two queens of their antennæ and introducing both to the same hive, when the bees did not appear to know their own from the stranger; but the moment he added a thind, still in possession of these organs, they fell upon her with murderous intent. Huber further points out that a moonlight night is the best time for observing the use of the antennæ as feelers. The bees, if it is warm, circumambulate their doors, to all appearance as vigilant sentinels, with these appendages stretched right before them; and woe to the moth that comes within reach-the instant it is felt its death follows.

The sense of hearing has been denied bees by some, but against all evidence; others contend that the seat of this power is also situate in their antennæ. The sounds which bees emit, particularly at swarming time, are conclusive that they possess this faculty; the only reasons for arriving at an opposite conclusion seem to be, that they are indifferent to most sounds, even the loudest, not emitted by themselves-but even to this there is the notable exception of the fright they evince at drumming on their hives-and that no precise organ of hearing can be found. Naturalists are now more united in the opinion that the seat of hearing is here located. The 
antennæ are said to have also another office, viz., that they act as a barometer, by which bees know the state of the weather and are premonished of storms; the darkening of the sky seems, however, to be frequently the cause of their trooping homeward, though they care not for the loudest thunder, so long as the sun continues to shine. In the dark recesses of the hive the feelers are exceedingly serviceable, and may truly be denominated "eyes to the blind."

Bees possess acutely the sense of smell, and, attracted by the fragrance of flowers, they may be seen winging their way a considerable distance in an undeviating course, even sometimes in the face of weather which one might have thought they would not have braved. The precise seat of this sense, however, is another doubtful point. Dr. Dünhoff ascribes this also to the antennæ, stating that if these are cut off the bees lose the faculty, but regain it after a time. Schönfeld takes this as proving the case the other way; but are we not familiar with analogies in which on the loss of some organ its function has been developed elsewhere-especially when as here the rudiments of the lost part must have remained? Schönfeld's own surmise is that the faculty resides in the surfaces of the inner respiratory organs; Dr. Hicks (the assistant author of Samuelson's “Honey Bee") places it in a number of vesicles at the roots of the wings; others again attribute it to two depressions in the lower portion of the face. But Dönhoff's reference to the antennæ 
has experiment, to our view, in its.favour, though of course not decisively so. But whether this is correct or not, this pair of horns play an important part with the useful faculties which they combine.

With their extraordinary devotion to sweets, bees can hardly but be possessed of a strong sense of taste, though in consequence of their being detected occasionally lapping the impure liquids from stable or ather foetid drains, Huber considered it the least perfect of their senses. But it is now ascertained that bees, like most animals, are fond of salt, and they therefore resort to dunghills and stagnant marshes, from which they are doubtless able to extract saline draughts. It cannot be denied, however, that, according to our ideas, their taste is otherwise at fault; thus it sometimes happens that, where onions and leeks abound and are allowed to run to seed, bees are so anxious to complete their winter stores, that, from feeding on these plants, a disagreeable flavour is communicated to the honey (see Chap. VI. $\S$ iii.).

\section{§ III. THE THORAX AND ORGANS OF MOTION.}

The thorax or chest approaches in figure to a sphere, and is united to the head by a thread-like ligament. This is the centre of the organs of motion. Here are attached both the muscles that move the legs and wings. and the legs and wings themselves.

In Fig. I of Plate II., $b, b, b$ show the muscles that move the wings; $e, e$, the bases of the wings. These 
appendages consist of two pairs of unequal size, which are arranged to hook together. In Plate I. Fig. A will be seen the margins of the two wings. In Fig. $B$ are the eighteen or twenty hooks placed on the anterior margin of the hinder wing, whilst the posterior margin of the fore wing is beautifully folded over to receive them, so that, when employed in fanning for ventilation, the two wings on each side act as one, and present an unbroken surface to the air. The wings of workers are larger than those of the queen, but those of drones are much larger still.

The bee has six legs, three on each side. Each leg is composed of several joints, having articulations like a man's arm, for the thigh, the leg, and the foot. The foremost pair of these are the shortest; the middle pair are somewhat longer, and with them the bee unloads the little pellets from the baskets on her thighs; the hindmost are the longest of all. On the outside of the middle joint of these last there is, in each leg, a small cavity, in the form of a marrow-spoon, called the "pollen basket." The pollen is conveyed from the front to the second pair of legs, and from these to the receptacles in the hind ones. Fig. $2 b$ in Plate I. shows the inner side of the hind leg and pollen brush; $2 b^{*}$, the outer side and pollen basket. On entering a flower a bee often covers itself with pollen, and hence the need for the brush apparatus on reaching home.

The legs are covered with hairs, more particularly the 
edges of the cavity mentioned, in which the kneaded pollen requires to be maintained securely. In this they convey those coloured loads which are so constantly seen carried into a hive. This basket, or pollen groove, in the thigh is peculiar to the worker; neither queen nor drone has anything of the kind.

Another provision of the bee's limbs consists in a pair of hooks attached to each foot, with their points opposite to each other, by means of which the bees suspend themselves from the roof or sides of hives, and cling to each other as they do at swarming time or prior to and during the formation of new comb, thus forming a living curtain. In these circumstances each bee, with its two fore claws, takes hold of the two hinder legs of the one next above. This mode of suspension seems agreeable to them, although the uppermost in the festoon appear to be dragged by the weight below. Wildman supposed that bees had a power of distending themselves with air to acquire buoyancy, and thus lessen the burden of those at the top. They find no difficulty in extricating themselves from the mass; the most central of the group can make its way without endangering the stability of the grape-like cluster.

Bees are able to walk freely in an inverted position, either on glass or other slippery substances. The peculiar mechanism of their feet, which enables them to do. so, consists in their having in the middle of each hook a thin membranous little cup or sucker that is alternately 
exhausted and filled with air. Flies have the same beautiful apparatus-hence a fly commonly selects the ceiling for a resting-place. These little air-cups, or exhausted receivers, may be seen by applying a strong magnifying-glass to a window that has a bee traversing the reverse side. The edges of these little suckers are serrated, so as to close against any kind of surface to which their legs may be applied. This apparatus may be also serviceable for gathering the pollen before transmitting it to the baskets on the hind legs. Besides these appendages and apparatus of the thorax, that region is traversed by the cesophagus or gullet (the opening to which will be found in Plate I. Fig. 2 c), on its way to the digestive and other organs, situate in the third part of the insect-viz, the abdomen. The covering of the thorax, with the external covering of the gullet, may be seen in the drawing of the magnified dissected body of the bee (Plate II. Fig. 1).

The breathing apparatus of bees is a very remarkable feature: they have no lungs, but, instead, air-vessels, or tubes and bladders ramifying through every part of the frame. The external openings of these, which are called "spiracles," are found in the sides of their bodies behind the wings. Two pairs of them are located in the thorax, and one pair on each side of the scales of the abdomen. They would be difficult' to show in a drawing, as the multitude of hairs which protect them are in the way of getting at a very distinct delineation. The 


\section{§III.] THORAX AND ORGANS OF MOTION. IOI}

writer has traced their oval form by the aid of Messrs. R. and J. Beck's "Binocular Microscope," and exceedingly interesting objects they appeared. From the circumstance of bees breathing through these orifices in their bodies, it will not be difficult to understand how sadly the little creatures must be inconvenienced when by accident they fall on loose mould, and thus have theibreathing pores choked with dust; it also shows how needful it is to prevent bees being besmeared with honey (by using bad appliances for feeding), which is still more injurious to them. The air-vessels are all that they possess of a circulating system, as bees have neither lungs, heart, liver, nor blood. It appears, however, that a white fluid matter, called "chyle," which in degree answers the purpose of blood, is produced in the intestines, nourishes the body, receives the oxygen from the air-vessels, and generates that animal warmth so necessary for the insect's well-being-warmth which, as a matter of course, say Schmid and Kleine in their "Leading Threads," settles that it is incorrect to call the insect a cold-blooded animal. Bees have the power of counteracting superabundant heat by perspiration. Not unfrequently, on a hot summer's morning, a good deal of moisture may be noticed at the entrance of a crowded hive, which the inmates have been enabled to throw off. This is a healthy sign, because a sign of great numerical strength. The humming sound always to be heard in a beehive is produced by breathing. 
§ IV. THE ABDOMEN ANND SECRETIVE ORGANS.

The abdomen, attached to the posterior part of the thorax by a slender ligament, has, for an outer covering, six folds or scales of unequal breadth, overlapping each other, and contains the honey-bag, or first stomach, the ventricle, or true stomach (Plate II. Figs. I and $2 f$ ), with other intestines, to be hereafter referred to.

The honey-bag (Figs. I and $2 d$ ) is an enlargement of the gullet, and, although called the first stomach, no digestion takes place here. In shape it is like a taper oil-flask; when full it is about the size of a small pea, and so transparent that the colour of the honey may be seen through it. This sac, as it is sometimes called, is susceptible of contraction, and so organised as to enable the bee to disgorge a part of its contents at will, to fill the honey-cells of the hive. It has been much controverted whether any or what change takes place in the nectar of flowers whilst in the bee's stomach (Chap. VI. § iii.).

A short passage leads to the ventricle or true stomach (Figs. I and $2 f$ ), which is somewhat larger. This receives the food from the honey-bag, for the nourishment of the bee and the secretion of wax. The stomach, like the honey-bag, has a considerable number of muscles, which are brought into play to help the digestive and other organs. The biliary vessels (Figs. I and $2 h, h$ ) receive the chyle from the digested food in the stomach, which from thence is conveyed to all parts of the Dody for its 
§ IV.] ABDOMEN AND SECRETIVE ORGANS. I03

support. "A bee," says Dzierzon, "with the honey which she can take into her stomach, is able to subsist abundantly under some circumstances for longer than a week, while under others she will die of hunger within tiventy-four hours. If we regard life as a process of combustion, then with the bee it resembles at one time the spark just glimmering in the ashes, at another the bright up-bursting flame that in a few minutes consumes the fuel, which to the barely glimmering fire would have ensured nutrition for a much longer time."

Wax is the animal fat of the bees, and to produce it requires a considerable consumption of honey to supply the drain upon the system. To be capable of passing through the pores of the abdomen, the wax must no doubt be a liquid oily matter, which, on making its appearance outside the abdominal rings, thickens, and exudes from under the four medial ones, in flakes like fish-scales, one on each side; so that there are eight of these secreting cavities, which are peculiar to the worker, not being found either in the queen or drone. The shape of these cavities is that of an irregular pentagon, and the plates of wax, being moulded in them, exhibit accordingly the same form (see Plate II. Fig. $6 w$ ). No direct channel of communication between the stomach and these receptacles, or wax-pockets; has as yet been discovered; but Huber conjectures that the secreting vessels are contained in the membrane which lines them, and which is covered with a reticulation of hexagonal 
meshes, analogous to the inner coat of the second stomach of ruminant quadrupeds.

The last important organ of the abdomen is the sting. This small but effective weapon is situate close to the stomach, and is found in the queen and worker, but is absent in the drone. Our engraving (Plate II. Fig. 4) exhibits the sting of the worker bee with its muscles and attachments: $r$-shows the muscles that move the sting, and $q$ the curved base of the outer sheath by which it is enclosed. Much beautiful mechanism is observed on a microscopic examination of this weapon, so wonderfully powerful in comparison with its bulk. The sting is composed of three separate portions, each of which is double - the dart, and the inner and outer sheaths. Very confusing accounts are given of this organ in different works, owing probably to the term "sheath" being applied by some to the outer and by others to the inner covering. The outer one consists of two fleshy curved claspers ( $q$ in the figure), inside of which is the linear sheath, which forms an essential portion of the sting, and consists of two horny scales closely adherent to the darts. These last are composed of stiff filaments, which at the outer end are each barbed with from five to ten teeth on one side; and they slide within the inner sheath, and that within the outer, on the principle of the tubes of a telescope. As represented in our engraving, the inner sheath clasps the darts to a level with the tips of the outer one. 
§IV.] ABDOMEN AND SECRETIVE ORGANS. I05

The darts are first protruded in the act of stinging, and, by aid of the powerful muscles on each side at $s$, are buried in the flesh to the depth of one-twelfth of an inch ; the inner sheath then follows, and at the same time, by a muscular contraction, the poison is forced along the groove in which the darts work, causing the well-known painful effects which arise from the sting of a bee. These darts are of slightly unequal length, so that the teeth on each side are not opposite to each other. From this arrangement it is easier for them to penetrate the flesh, and alternately deepen the wound, while the teeth successively hold each firm as it makes its way, until the poison has been ejected. If the sufferer could only command himself so as to remain perfectly passive, the bee might be able to draw in these darts which protrude beyond the sheath, and would then have a chance of withdrawing the sting ; the little insect would consequently inflict less pain, and might perhaps escape paying the penalty of her life. It generally happens, however, that the excitement of both parties is so great, that the poor bee leaves behind the whole apparatus, and even part of her intestines, so that her death is the result, and the wound is more severe. The sting is about the sixth part of an inch long, and is largest at the base. Here are situated the glands or ducts (Fig. $4 u$ ). By these the poison is secreted and passed into the poison-bag (Fig. $4 t$ ), which acts as a reservoir for retaining it till required.

On the subject of the sting Paley remarks: "The 
action of the sting affords a beautiful example of the union of chemistry and mechanism: of chemistry, in respect to the venom, which in so small a quantity can produce such powerful effects; of mechanism, as the sting is not a simple but a compound instrument. The machinery would have been comparatively useless had it not been for the chemical process, by which, in the insect's body, honey is converted into poison; and, on the other hand, the poison would have been ineffectual without an instrument to wound and a syringe to inject the fluid." As before stated the drone has no sting, but, in place thereof, the organs of reproduction, on which, as on the corresponding organs of the queen, sufficient has been remarked above (pages 24 and 63).

And now, in concluding this section, we would remark the wonderful contrivance and finish which all the works of the Great Master Artificer unfold. In the works of man we see, perhaps, a piece of mechanism of unquestioned beauty and excellence, yet there is a bolt here or a screw there that might have been dispensed with, and does not possess any definite use. But in the works of Nature everything has a place; we may not at once comprehend the exact purpose of some intricate parts, but that only implies that we have not made a thorough investigation. The most minute hair serves its required end. Some reflections of Dr. Evans, though chiefly referring to the cells of bees, may not inappropriately finish this chapter :- 
"On books deep poring, ye pale sons of toil, Who waste in studious trance the midnight oil, Say, can ye emulate, with all your rules, Drawn or from Grecian or from Gothic schools, This artless frame? Instinct lier simple guide, A heaven-taught insect baffles all your pride. Or ye on theory's wild wave that roam, And skim from science but its froth and foam, Who wield 'gainst Truth the sharp yet shivery lance, Devoted bending to your iclol, Chance ;

Oh ! say, could Chance her lawless atoms bind, And weave the tissued woof of sense and mind, Or her blind impulse in yon mansions trace The firmest fabric with the amplest space? No! while ye boast to bow at Reason's shrine, That Reason bids you hail the Power Divine. Not huge Behemoth, not the whale's vast form, That sponts a torrent and that breathes a storm, Transcends in organs apt the puny fly, Her fine-strung feelers, and her glanceful eye Set with ten thousand lenses. Not the pile By fabled giant raised in Erin's isle, Not Staffa's crystalled shore, where now, Fingal, Roar the hoarse surges through thy columned hall, Nor all yon marshalled orbs that ride so high, Proclaim more loud a present Deity, Than the nice symmetry of these small cells, Where on each angle genuine Science dwells, And joys to mark through wide creation's reign How close the lessening links of her continued chain."

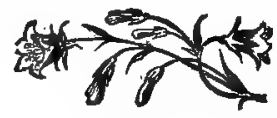




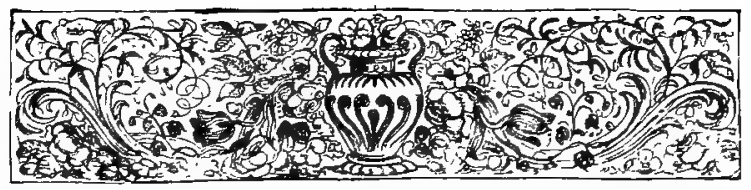

\section{CHAPTER III.}

\section{MIODERN BEEHIVES.}

\section{COMMON COTTAGER'S HIVE.}

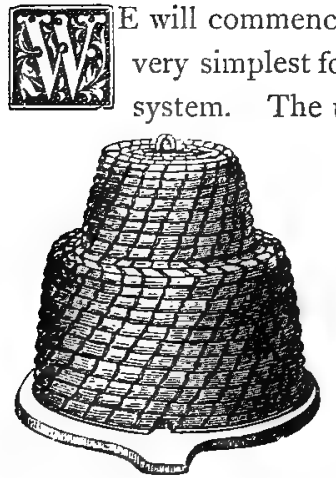

ce our list of hives with this, the very simplest form or adaptation to the depriving system. The upper hive is intended for a super and the lower one is the "stock" for the bees' settled habitation. The directions for applying this, as well as for stocking the hive and taking the honey, will however be obtained under the head "Neighbours' Improved Cottage Hive" (page I I6), and in the sections referred to there on "Hiving Swarms," "Applying Supers," etc. The hive is well suited for those who are desirous of leading their poorer neighbours into the humane system of bee-keeping. See the remark at the end of the next section respecting the hole for giving admittance to the super. 


\section{§ II. NEIGHBOURS' CRYSTAL PALACE SKEP.}

This hive (so styled from its obtaining a prize at the Crystal Palace Show in 1875 ) differs from the foregoing in being larger, and in having a thicker floorboard, a hooped fitting at the base, a window in the super, and a movable cap as a finish to either super or stock hive, according as the former is in use or not. The outside dimensions of the lower hive are seventeen inches diameter by nine in depth, and of the super thirteen inches by five.

When there is a hole in the centre on top of the stock hive, as is the
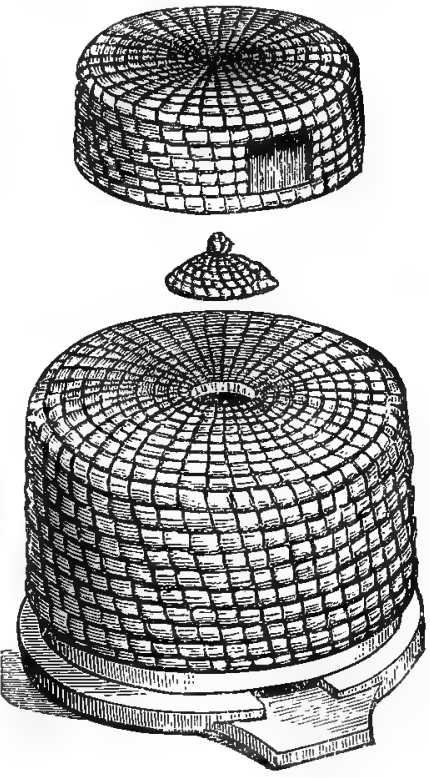
case here, there is a possibility of the queen ascending and depositing eggs in the super. To check such a mishap, a queen and drone preventer can be applied, which is a contrivance so arranged as to admit the passage of nothing larger than a worker (Chap. IV. $\S$ xvii.). 


\section{§ III. THE COTTAGER'S HIVE.}

This is our more complete form of a cottager's hive, composed entirely of straw. A very prevalent opinion

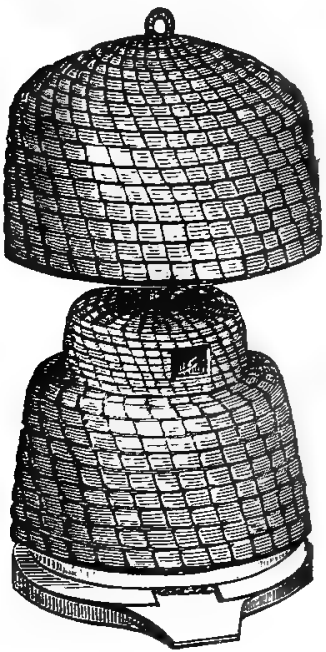
exists that bees do better in hives of that material than of any other. Another opinion prevails, that the old-fashioned straw hive is the least expensive, the most simple, and the most productive. Although we cannot go so far as this, we are willing to admit that a simplified adaptation of the humane system to the old common straw hive is the most suitable to put into the hands of that large class of bee-keepers-cottagers. By these the more fanciful hives will be instantly condemned; besides, the expense puts them quite beyond the reach of the poorer class. The object aimed at in planning this structure has been to furnish a depriving hive that should be at once easy of management, inexpensive, and convenient. The stock hive, in which the bees are first deposited, is round, and has a flat top with a hole in the centre. The size of this lower hive is nine inches deep outside, and fifteen inches across the bottom; it is finished with a wooden hoop, 
which adds very much to its firmness and durability. The floor-board is one inch and a quarter thick, with a way sunk therein for the entrance. A small round mat of straw closes the hole in the top; this mat may be fixed by wooden pegs. We have now described what is termed the stock hive, which is, in fact, an old-fashioned straw hive, adapted, modernised, and improved to the more humane, viz., the depriving system. The weight of the stock hive, with its floor-board, is about seven pounds.

The super is five inches deep outside and twelve or so in diameter, and, when filled, contains about twelve pounds of honey and comb. Its purpose is exactly identical with that of the three bell glasses described on page I 7 : the lower hive is for the breeding compartment and for the storage of honey for the bees' own consump tion, while the upper is to receive the surplus of their treasure which the owner intends to appropriate pure for himself. A glass window, which is placed at the side of the super, is useful for inspecting the progress made in filling it. An adapting-board to facilitate removal is added underneath it by some.

A common straw hive, sufficiently deep to cover, drops over the super, keeping the window dark, and fitting close on to the stock hive. This cover hive may be made fast by driving in two skewers, one on each side, to keep the whole firm. Unless placed in a bee-house or under a shed, the outside should be painted; or a 
piece of oilcloth, or waterproof covering of any kind, shaped so as to shoot off the rain, will save the trouble of paint, and answer the purpose (see Chap. IV. §iii.).

The mode of stocking this hive, and of taking the honey, will be clearly gathered from the directions under $\leqslant \mathrm{v}$. below, and from the general instructions in the sections therein referred to. After two or three weeks the straw mat may be removed to give the bees access to the super.

\section{S IV. AX IMPROVED COTTAGER'S FITVE.}

This hive is very superior to the one described just above, as it possesses a Taylor's glass in lieu of a straw

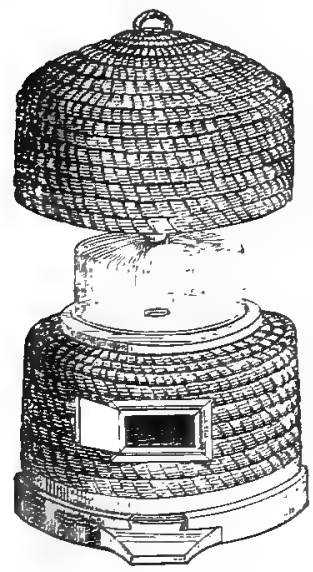
super, and an adapting-board and a window in the lower portion. Its principle is also exactly the same as that of the succeeding, which is simply a more elaborate development of this hive. Our illustration places the window over the entrance, being so drawn in order to exnibit back and front at one view, whereas in reality it is on the opposite side at the back, so as to allow of an inspection free from the liability of annoyance from the bees. For directions see the next section. 

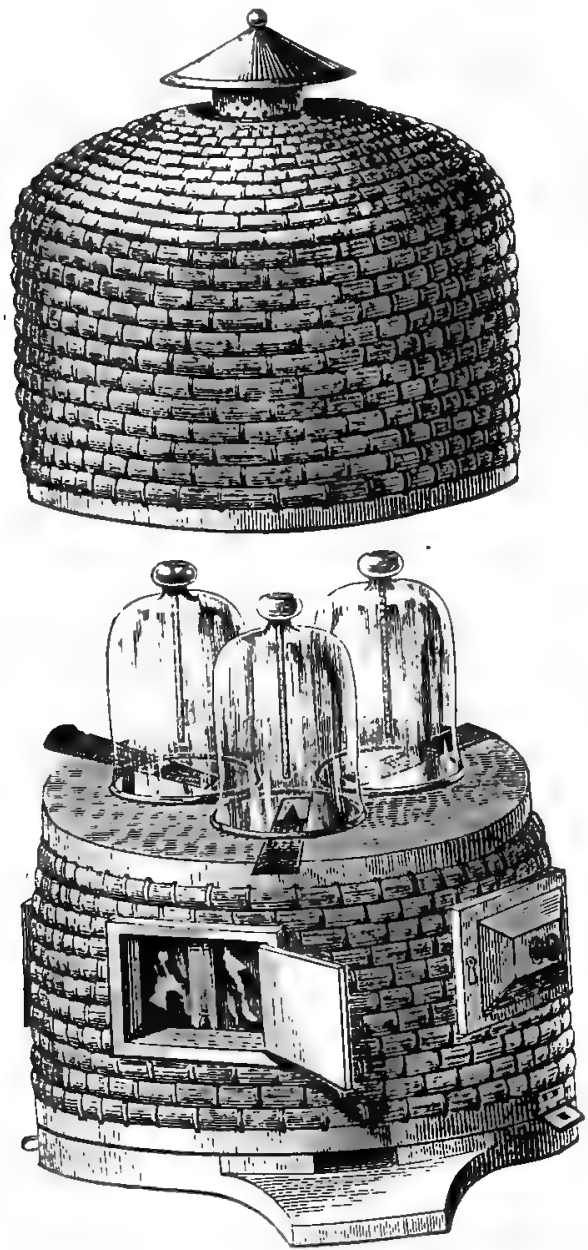


\section{§ V. NEIGHBOURS' IMPROVED COTTAGE HIVE.}

Our improved cottage hive (shown page I I3), is neatly made of straw bound with cane, and therefore very durable." The lower hive is covered with a wooden top, having in it three holes, through which the bees convey their honey into three middle-sized bell glasses with ventilators, which, when filled, hold about six pounds each. There is a hoop at the bottom, another round the top of the lower hive; to this the wooden crown-board is fastened. These hoops are a great improvement, and are less liable to harbour insects than if straw alone were used. The floor-board, as its name implies, is a wooden board one inch and a quarter thick, with a projection of three or four inches under the entrance to form an alighting-place. This entrance is cut out of, or sunk in, the board. There are three windows in the lower hive, each closed with a shutter; these are very useful and interesting for inspecting the progress made. Across the centre window is a thermometer, enclosed at the sides by slips of glass. The window shutters, being of oak colour, add very much to the appearance. The upper hive, which is merely a cover for the glasses, is made like the lower;

* This is the hive referred to by the "Bee-Master" of the Times (Dr. Cumming) when he says : "The second kind of hive I alluded to is made of straw, and may be purchased at Neighbours', in Holborn. . . . It is so well made that it will last very long. I have had one in constant use during ten years, and it is still as good as when it was bought." 
a hoop is worked into the straw, and is sufficiently large to allow the cover to drop over the crown-board, keeping the whole close, and preventing wet from drifting in. A zinc ventilator, ornamentally painted, forms the apex : this is useful in letting the confined hot air pass away in warm weather. The ventilator is opened by raising it. The lower or stock hive is fifteen inches in diameter and nine and a half in depth outside; its weight, when empty, is seven pounds and a half. The cover, or top hive, is twelve inches deep and fifteen inches in diameter; the ornamental zinc top being four inches deep. The whole is about twenty-four inches high. The weight of a hive packed, including glasses, is about eighteen pounds.

These hives have a tasteful appearance in the garden, but they require some further protection from the weather in the form of a cover or of a bee-house-contrivances that have yet to be described. In extreme cold weather a little additional protection, by having matting folded round them, will be advisable.

One of the advantages of this and the preceeding hives over the ordinary cottage hive is that they afford ready opportunity for the humane management of bees. The bell glasses also give the owner the power of taking honeycomb of pure quality, free from the extraneous matter known as "bee-bread," instead of combs that are darkened by having brood hatched in them. By this system we have combs newly made and used only for depositing the honey first put into them: hence the name "virgin 
honey." These glasses have a very pretty appearance, and, when nicely filled, are very convenient for home use or for making presents. The lower hive is the receptacle for the bees; when a swarm is placed in this hive they immediately proceed to fill it with combs for the storage of honey for their own use, and for cells to breed in. This hive remains undisturbed.

The best mode of tenanting a hive of this description is by placing an early and strong swarm in it, which may be generally procured of a neighbouring bee-keeper; if from a distance, considerable care is necessary to admit plenty of air (Chap. V. $\S x i$.$) . For the purpose of venti-$ lation, remove the slides and substitute perforated zinc, wrapping the hive up in a coarse cloth of open texture (dispensing with the floor-board during transit when the distance is great and the temperature warm). It is necessary only to send the lower or stock hive to the party furnishing the swarm, taking the precaution to fix the slides at top with tacks, as the hive has to be inverted to receive the bees. Some older bee-keepers prefer to give it a little dressing with syrup, beer, or herbs; there can be no objection to the first, but other scents may not be pleasant to the insects and are far better avoided, as also are the sticks so often inserted, they being almost certain to cause crooked combs. The bees, if swarming, are shaken into the hive, as described in Chap. V. $\$$ i.; if transferred from another hive, the directions will be found in a following section of the 
same chapter. Towards evening close the entrance, and remove them to the exact position they are intended permanently to occupy. Success depends on this, and also on their careful removal on the evening of hiving. The following morning they will labour in their new location, marking well their habitation before they take flight, and not failing to return to it loaded with luscious store.

The general directions must be observed in applying the supers (Chap. V. $\S$ xiii.). When the time arrives the thermometer will rise rapidly to roo degrees or upwards. To prevent swarming the zinc slides on the wooden top must now be withdrawn, and the bell glasses put on, covered and protected by the upper hive; a day or two after which all signs of swarming will at once disappear, the bees now having increased storage-room, which they will readily fill with comb. The ventilator should always remain open during the day, to allow the hot air to pass away from the interior, thereby contributing to the whiteness and beauty of the work; the bees enjoy the refresh. ment of coolness thereby afforded, and they work the faster for it. At evening all ventilation should be stopped, and the glasses wrapped round with some warm material. We now supply flannel-lined baize bags to each glass sent out with the hive.

The directions for taking honey are much the same as usual (Chap. V. § xiv.). A slide seven inches and a half square is furnished with the hive, and is useful to remove 
the g'ass upon. The holes in the wooden top of this hive are of a peaked shape, to act as a preventive against slaughtering any bees whilst pushing the slide in for the purpose of removing the glass when full. The tacks before alluded to should be removed from the slides when the hive is fixed in its place. The entrance slide is very serviceable during the winter months to lessen the passage-way, thereby preventing the admission of too much cold air; it is also occasionally useful on a summer evening to lessen the entrance when moths are troublesome, for if there be only a small opening the bees can guard it and easily repulse intruders. During the time of gathering they require the whole width to remain open.

The pedestal, shown on the right in the next figure, as originally sent out, has a hole through each of its feet, and must be firmly fixed in the ground by means of the four iron pegs supplied with it for the purpose ; to prevent rotting, it is well also to place a brick under each foot. The hive must then be made fast to the stand as a precaution against high winds. The latter is about twenty-two inches in height.

The simplicity and easy management of this hive have rendered it an especial favourite, combining as it does real utility with many conveniences to satisfy the curious. Not a few bee-keepers desire to unite the two qualifications, and no hives combine these advantages in a greater degree than the one we are now describing. 
A cheaper form of this hive is here represented, of precisely the same size and construction, with the ex-
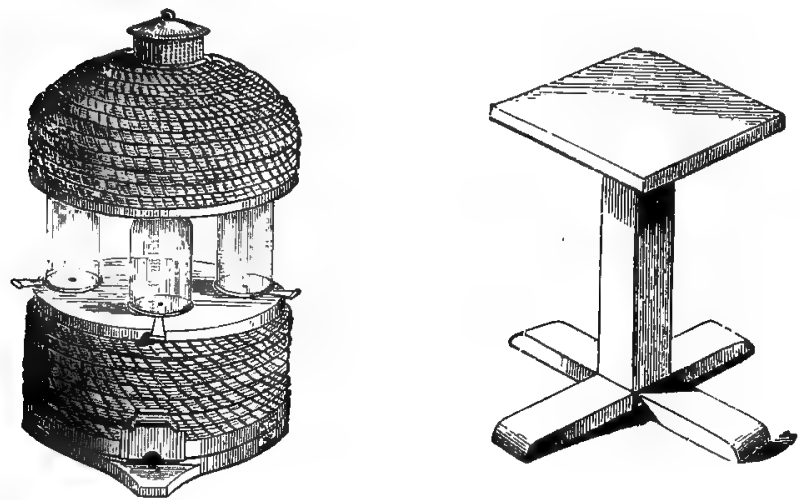

ception that it has no windows or thermometer. The apiarian with this hive will therefore have to trust more to his own judgment as regards the likelihood of swarming, and must watch the appearance the bees present at the entrance. When it is time to put on supers in order to prevent swarming, premonition will be given by the unusual numbers crowding about the entrance, as well as by the heat of the weather, making it evident that more room is required for the increasing population. At Michaelmas the directions as to weighing must be attended to (see Chap. V. § xviii.). 


\section{$\$$ VI. THE LADIES' OBSERVATORY HIVE.}

The following illustration shows the construction of this hive. The stock hive is of stout glass, and cylindrical,

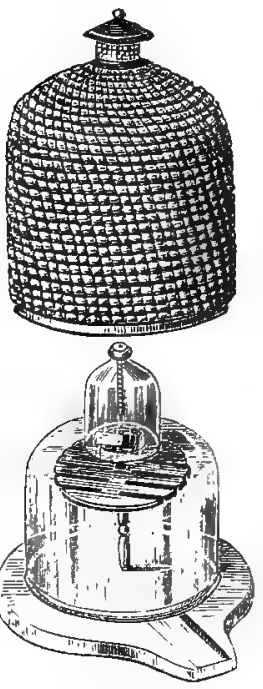
with a flat top and a hole in the centre; it is thirteen inches in inside diameter and eight inches and a half deep. A support, composed of even wooden bars fixed on a pedestal from the floor-board, is very useful for the bees to cling to and secure their combs, instead of resting wholly against the glass.

The floor-board is of mahogany, the border being French-polished. A middle-sized bell glass, for deprivation, is placed over the hole; this hole may be closed by a zinc slide. A cover of straw, eighteen inches deep and fifteen inches wide, with a zinc ventilating top similar to that affixed to the cottage hive, completes the arrangements. The weight of the stock hive and board is about sixteen pounds. In the figure the cover is shown lifted to display the interior: In a thoroughly warm room it may be kept entirely off.

This hive is well adapted for those persons who are desirous of having the opportunity of making a closer examination of the workmanship of these industrious and 
interesting insects, as the whole of the interior may be exposed to view; it is particularly suitable for a window or an indoor apiary, and will also be found a valuable addition to the greenhouse. Under these circumstances the entrance-way should be covered with a flat piece of glass, and an aperture cut in the sash corresponding with the entrance to the hive; through the glazed passage the bees may then find egress and ingress without being able to gain access to the apartment. An alighting-board, four inches wide, must be fixed outside on a level with the entrance.

We had a hive of this kind in operation at the Great Exhibitions of $185 \mathrm{I}$ and 1862 , fixed after the manner above described. It answered admirably, and excited much interest and curiosity, though placed there under many disadvantages.

When a hive of this kind is to be stocked, proceed in the main as with ordinary transfers (Chap. V. §ii.), but place the floor-board and support of the hive in the middle of the sheet or swarming-board, and precipitate the bees as much as possible on to the support; cover them with the glass, propping it up with bricks or other rests sufficiently high to prevent the bees being squeezed. They will collect under the bars and on the pedestal, and in about one hour's time the whole will have settled quietly, and all the stragglers on the board will have collected together, the swarm hanging pear-shaped from the bar support; the bricks can now be removed, and the glass put 
in its right place on the floor-board. The straw cover can now be set down over all, and the hive can be removed to the place it is destined permanently to occupy.

The light should not be admitted for some days after hiving; if undisturbed, the bees will speedily build comb, working from the wooden bars, which are placed there for their assistance and support. In ten days or a fortnight, if the weather continue fine and warm, they will prepare to swarm again; the opening at the top must now be unstopped, and the bell glass put on, guidecomb having been previously fixed. The directions given as to these matters for the preceding hive apply equally to this one.

It is advisable in winter to furnish the glass stock hive with more protection from cold than is afforded by the straw cover alone; some thick baize, or wrapper of wadding, for which there is space between the glass hive and the cover, will prevent so much moisture condensing on the sides of the glass. As remarked under "Winter Precautions" (Chap. V. $\$ \mathrm{xx}$. ), it is only by the very greatest care that bees can be brought through that season in a glass hive.

The hole at top is used for supplying food, should the apiarian fear the stock of honey is in danger of running short; either feeder may be used for the purpose (Chap. IV. $\S \mathrm{xx}$.$) .$ 
§ VII. NUTT'S COLLATERAL HIVE.

The late Mr. Nutt, author of "Humanity to Honey Bees," may be regarded as a pioneer of modern apiarians; and though his hive is now comparatively little used it is still worthy of description from the part it has played in the history of bee-keeping.

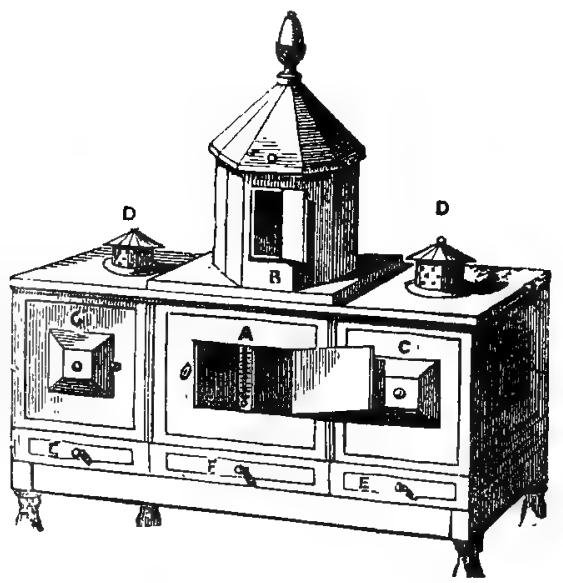

It consists of three boxes placed side by side (C, A, C), with an octagonal box (B) on the top, which covers a bell glass. Each of the three boxes is nine inches high, the same wide, and eleven inches from back to front. Thin wooden partitions, in which six or seven openings corresponding with each other are made, divide these compartments, so that free access from one box to the other is afforded to the bees; this communication is 
stopped, when necessary, by a zinc slide passing down between. The octagonal cover $\mathrm{B}$ is about ten inches in diameter and twenty high, including the sloping octagonal roof, surmounted with an acorn as a finish. There are two large windows in each of the end boxes and one in the centre box. Across the latter is a thermometer, scaled and marked, so as to be an easy guide to the bee-master, showing him, by the rise in temperature, the increased accommodation required; this thermometer is a fixture, the indicating part being protected by two pieces of glass, to prevent the bees from coming between it and the window, and thereby obstructing the view.

$\mathrm{D} D$ are ventilators. In the centre of each of the end boxes is a double zinc tube, reaching down a little below the middle : the outer tube is a casing of plain zinc, with holes, about a quarter of an inch wide, dispersed over it; the inside one is of perforated zinc, with openings so small as to prevent the escape of the bees; a flange or rim keeps the tubes suspended through a hole made to receive it. The object in having double tubing is to allow the inner one to be drawn up, and the perforations to be opened by pricking out the wax, or rather the propolis, with which bees close all openings in their hives. These tubes admit of a thermometer, enclosed in a cylindrical glass, being occasionally inserted during the gathering season; it requires to be left in the tube for about a quarter of an hour, and on its withdrawal, if found indicating ninety degrees or more, ventilation must 
be adopted to lower the temperature. "The grand object," as MIr. Nutt expresses it, "is to keep the end boxes and the bell glass cooler than the pavilion or middle box, so as to induce the queen to propagate her species there and there only, and not in the depriving part of the hive; by this means the side and upper combs are in no way discoloured by brood. The queen requires a considerable degree of warmth; the middle box does not require more ventilation than the additional openings afford. The bees enjoy coolness in the side boxes, and thereby the whiteness and purity of the luscious store are increased." The ornamental zinc top $\mathrm{D}$ must be left raised, and is easily kept in that position by putting the perforated part a little on one side.

The boxes before described are placed on a raised double floor-board, extending the whole length--viz., about thirty-six inches. The floor-board projects a few inches in front. In the centre is the entrance (as our illustration only shows the back of the hive we must imagine it on the other side); it is made by cutting a sunken way, of about half an inch deep and three inches wide, in the floor-board, communicating only with the middle box; it is through this entrance alone that the bees find their way into the hive, access to the end boxes and the super being obtained from the inside. An alighting-board is fitted close under the entrance, for the bees to settle upon when returning laden with honey. This alighting-board is removable for the convenience of 
packing. The centre, or stock box, A, called by Mr. Nutt the Pavilion of Nature, is the receptacle for the swarm. E E are two block fronts, which open with a hinge. A semicircular hole, three inches long and two wide in the middle, is cut in the upper floor-board immediately under the window of each box; these apertures are closed by separate perforated zinc slides. The blocks, when opened, afford a ready means of reducing the temperature of the side boxes, and they are also useful for allowing the bees to throw out any refuse.

The centre $\mathrm{F}$ is a drawer, in which is a feeding-trough,

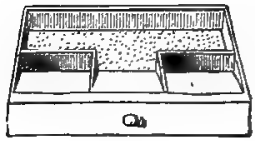
so constructed that the bees can descend through the openings just mentioned on to a false bottom of perforated zinc. Liquid food is easily poured in by pulling out the drawer a little way; the bees readily come down on to the perforated zinc, and take the food by inserting their probosces through the perforations, with no danger of being drowned. Care must be exercised that the food is not given in such quantity as to come above the holes; by this means each hive has a supply of food accessible only to the inmates, with no possibility, when closely shut in, of attracting robber bees from other hives.

The exterior of these hives is well painted with two coats of lead colour, covered with two coats of green, and varnished: Notwithstanding this preservation it is absolutely essential to place such a hive under a shed 
or cover of some sort, as the action of the sun and rain is likely to decay the wood, whilst the extreme summer heat might cause the combs to fall from their foundations. Neat and tasteful sheds may be erected, consisting either of zinc or thatched roofs supported by iron or wooden rods, and they will form a pretty addition to the flower-garden. It will be well to make the covering a foot or two longer, so as to allow of a cottage hive on each side, as the appearance of the whole is much improved by such an arrangement.

The super will be almost sure to be filled first, having been first opened to the bees. This will be removed according to the general instructions. The removal of the end boxes is a somewhat similar process, but they should on no account be taken away at the same time as the glass, or, indeed, at a time when any other hive is being-robbed we were going to say, for it is robbery to the bees : they intended the honey for their winter food, and are much enraged at being deprived of it. First shut down the dividing tin; the bees in the end box are now prisoners separated from the hive; keep them so half an hour, and then take away the box bodily to another part of the garden, or into a dark outhouse.

\section{§ VIII. HUBER'S HIVE.}

To Francis Huber-not improperly styled "the prince of apiarians" - we are indebted for more extensive and accurate observations on the habits of the bee than have 
been contributed by all other observers since the time of Aristotle. We have here introduced a description of Huber's leaf hive (and should be glad to exhibit one) for the sake of its historic interest in connection with apiarian science. Though entirely gone out of use it was invaluable for Huber himself, and it suggested to other apiarians the adoption of the present plan of vertical bars and frames.

In connection with this last point of interest it seems fitting to introduce here some very brief account of the development of the movable-frame hive. From "time immemorial " there have existed bar hives-indeed, they have been traced to the ribbed carcase of Samson's lion. But in most cases the bars were not movable ones-they were simply designed to aid the purpose of keeping an upper story in some degree clear of the queen's intermeddling. And even when they were capable of removal they added but a slight step in advance, and the credit of the inventions of Golding in England and Dzierzon in Germany is due not to the bars themselves but to their mode of affixing, and especially to the guide-comb attached beneath. At about the same date with these there appeared a Russian hive known as the Propokovitsch, which consisted in an arrangement of several stories of frames inserted endways and resting on cross pieces below them. Thus one invention supplied bars without frames, while the other offered frames without bars. But the right idea had now been caught, and it is 
not surprising that several apiarians, independently and simultaneously, were engaged at this period in working it out.

Briefly summarised the sequel is as follows. In $\mathrm{r} 84 \mathrm{r}$ our own countryman Major Munn obtained a patent in France for his movable bar-and-frame hive, of which he published a description in England in $1844 ; *$ in America in $185 \mathrm{r}$ Mr. Langstroth completed the invention of his movable bar-frames; and in Germany in I853 Baron von Berlepsch by a distinct inventive process added the frames to Dzierzon's bars. Thus England appears after all to possess the honiour of the contrivance, although we certainly proved the last to make of it any general or extensive use. Major Munn's original hive opened at the back, and when in $185 \mathrm{I}$ he reappeared in print with a hive opening at the top, he had altered the frames (and hive too) from oblong to triangular. Probably one reason of the invention's failure was the expensiveness of the Major's fittings, which are such as to make the hive appear in his engravings more like some astronomical instrument than a box for bees and honey. Be this as it may, there was practically no such thing as a frame hive in use in England till 1860 , when Mr. Tegetmeier was the means of reintroducing it-

* "A Description of the Bar-and-Frame Hive invented by W. A. IIunn, Esq. :" London, Van Voorst, 1844 ; 2nd ed. 185 I. In his edition of Bevan's "Honey' Bee," brought out in 1870, the Major tells us that he had been for some years engaged in connection with this distinguished author (and we presume Mr. Golding) in the preparation of the above hive. 
whether from Germany or America we are not quite sure. The German hives, however, open at the end, while Mr. Langstroth's are like our own; so that, whoever was the inventor of bar-frame hives, the hive of English apiarians comes nearer to this gentleman's than to that of any one else. Mr. Woodbury it was who afterwards brought out the frame hive which met with the first general acceptance in this country.

Having made allusion to the construction of the German hives it may be acceptable to some if we append a few additional particulars. According to Von Berlepsch, the depth should be about sixteen inches, the length twentyeight, and the breadth only nine, so that the receptacle is high and narrow, and reaches a long way back. The frames, which fit crossways, are consequently much like our own turned up on end, or perhaps more frequently two frames are used, one as a story above the other. With the most approved hive (the "Lagerbeute") instead of supers the further end of the long box is partitioned off and goes by the name of the "honey-room." Then, as the only practical opening is at this end, not only must this "room" be cleared away equally with our supers before the brood frames can be got at, but none of these can be reached without taking out all the others that are in front of them. When supers are used the frames can be extracted without interfering with these, so that some advantage might then result from such arrangement; but generally speaking this operation of removal is a rare necessity while the supers are on. 
In some cases extraction at the top may be the more convenient, and in others at the end; and we have therefore in our Philadelphia hive (\$ xii.) endeavoured to unite the two advantages by supplying an opening both at the side and the top.

To return, however, to the subject of our present section. During the early period of Huber's investigations he prosecuted them by means of single-comb hives, which allow of each side of the comb being examined. $\mathrm{He}$ found, however, that there was one important defect. The bees could not in these hives cluster together, which is their natural method of withstanding the effects of a reduced temperature. Huber hit upon the ingenious expedient of combining a number of singlecomb frames, so as to form one complete hive, which could be opened, in order to expose any particular comb, without disturbing the rest. From the manner of the opening and closing of this hive it has generaliy been called the "Leaf or Book Hive." The division separating each comb is joined both back and front with "butt hinges," fastened with a movable pin, on withdrawing which, at both sides, each comb and the bees on it may be inspected as easily as if in a single-comb hive. Huber's leaf hive is thus in appearance as if several ordinary "History of England" chess-boards were set up on end together; but each single portion is distinct, instead of there being any coupling of twos. The floor-board on which the hive stands is larger than the hive when closed, so as to allow of its being opened 
freely at any particular "volume." An entrance-way for the bees is hollowed out of the floor-board as in other hives. There is a glass window in each end of the hive, which is provided with a shutter.

There is, however, one serious objection to Huber's hive, which, though not noticed by him or his careful assistant, has prevented its general use-that is, the difficulty there is in closing it without crushing some of the bees-a catastrophe which, by exasperating their comrades, is certain to interfere with any experiments. There is no such risk in the bar-and-frame hive, whilst in it every facility possessed by Huber's is retained.

The character of Huber and the circumstances under which he pursued his observations are so remarkable that we need scarcely apologise for stating a few particulars respecting him here. $\mathrm{He}$ was born at Geneva, in July $\mathrm{I} 750$, his family being in honourable station and noted for talent. Just as he attained to manhood he lost his sight, and remained blind to the end of his days. This apparently insuperable obstacle in the way of scientific observation was overcome by the remarkable fidelity with which Burnens, his assistant, watched the bees and reported their movements to Huber. Madame Huber also, who, betrothed to him before his calamity, had remained constant in her affection, assisted in the investigations with great assiduity during their long and happy wedded life. Huber, fortunately for science, was in a position to devote both means and leisure to these observations; and Burnens, though only a peasant, was a 
superior man, and rose by his worth to become chiefmagistrate of his native village. In later years Huber's son Pierre rendered important aid. We quote the following from " MLemoirs of Huber" by Professor de Candolle :-

"We have seen the blind shine as poets, and distinguish themselves as philosophers, musicians, and calculators; but it was reserved for Huber to give a lustre to his class in the sciences of observation, and on objects so minute that the most clear-sighted observer can scarcely perceive them. The reading of the works of Réaumur and Bonnet, and the conversation of the latter, directed his curiosity to the history of bees. His habitual residence in the country inspired him with the desire, first of verifying some facts, then of filling some blanks in their history; but this kind of observation required not only the use of such an instrument as the optician must furnish, but an intelligent assistant, who alone could adjust it to its use. $\mathrm{He}$ had then a servant named Francis Burnens, remarkable for his sagacity and for the devotion he bore his master. Huber practised him in the art of observation, directed him to his researches by questions adroitly combined, and, aided by the recollections of his youth and by the testimonies of his wife and friends, he rectified the assertions of his assistant, and became enabled to form in his own mind a true and perfect image of the manifest facts. 'I am much more certain,' said he, smiling, to a scientific friend, 'of what I state than you are, for 
you publish what your own eyes only have seen, while I take the mean among many witnesses.' This is doubtless very plausible reasoning, but very few persons will by it be rendered distrustful of their own eyesight."

The results of Huber's observations were published in I792, in the form of letters to Bonnet, under the title of "Nouvelles Observations sur les Abeilles." This work made a strong impression upon many naturalists, not only because of the novelty of the facts stated and the excellent inductive reasoning employed, but also on account of the rigorous accuracy of the observations recorded, when it was considered with what an extraordinary difficulty the author had to struggle.

Huber retained the clear faculties of his observant mind until lis death, which took place on the 2 and of December, $183 \mathrm{I}$. Most of the facts relating to the impregnation of the queen, the formation of cells, and the whole economy of the bee community, as discovered and described by Huber, have received full confirmation from the investigations of succeeding naturalists.

\$ IX. FIE WOODULRY IRAME HIVE.

I. Wood.-The late Mr. Woodbury's "Bar-andFrame Hive," as originally made, consists of a wooden box, fourteen inches and a half square inside, and nine inches deep. The actual habitable space inside is lessened by the room cccupied by the frames, of which there are ten; these rest on a rabbet a little below the 
surface, leaving a space of three-eighths of an inch between the upper side of the bars and the crown-board. This allows a free pas-

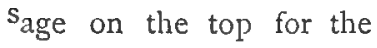
bees, entirely obviating the necessity of making excavations in the crownboard, as has hitherto been recommended. The frames are nearly an inch

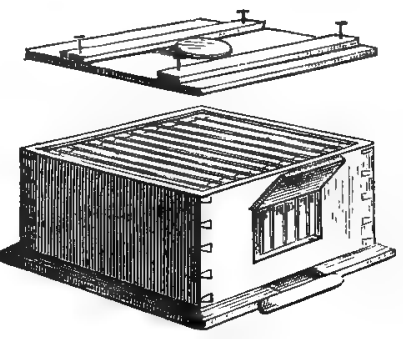
wide, and rest in notches, with spaces of half an inch between them; they extend to within three-eighths of an inch of the floor-board, so as to hang without touching any part, leaving about the same distance from the sides. It will be seen that there is thus a free passage for the bees on every side, so that they are kept from coming in contact with the sides of the hive. Our illustration shows the hive open, and exposes to view the top of the ten bars and frames, as they range front and back. A window is also shown; this is placed in the figure over the entrance, but the proper position would be just opposite. The drawing is made so as to show back and front at once.

As before mentioned, the stock hive has ten frames -each thirteen inches long by seven and a quarter high (inside measurement), with a five-eighths of an inch projecting piece at

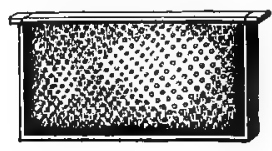


each upper end, which rests in the notches at back and front. We have placed this hive first in our list of modern frame hives in accordance with the part it has played in rendering them popular in this country as explained in the preceding section.

2. Straw.-Subsequently to the introduction of the above wood hive Mr. Woodbury recommended that the

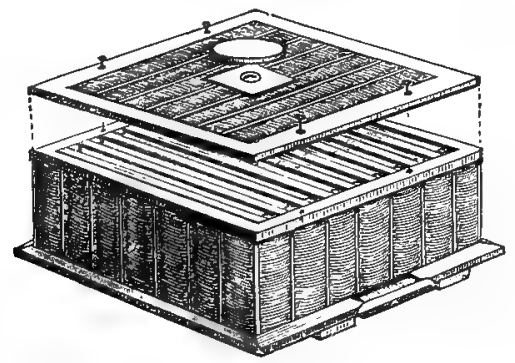

stock hive should be made of straw, of exactly the same dimensions; this material being warmer in winter, cooler in summer, more equable in temperature at all times, slightly ventilating, and allowing of absorption. Bees, during, cold weather, cluster together to generate the requisite degree of heat; the temperature of the interior of the hive being thus so much higher than the external atmosphere, a good deal of moisture condenses at the top and on the sides of the hive. The straw, as before stated, prevents this dampness hanging about within, and tends to keep the inmates more healthy.

The square straw hives, and a machine for making, 
them, exhibited in the Austrian department of the International Exhibition of 1862 , suggested the idea of employing that material for English frame hives. We have had a machine made resembling the one exhibited, and suited to the size in use by us, by which our hive-maker is able to manufacture neat square hives in straw. These have a wood frame at top, an inch deep, with the requisite notches to allow the ten comb-frames to hang. A similar frame forms the base, the straw being worked between. An inch projection is left on all sides of the floor-board beyond the exterior of the hive, from which it is slightly chamfered down. An entrance, four inches wide, is cut out of the substance of the board, beginning at the edge, and continuing on the same level until inside the hive, where it slopes upwards. This entrance is about three-eighths of an inch high where the hive crosses it.

These straw hives have been generally made without windows, as Mr. Woodbury and other scientific apiarians have so preferred them. They have considered glass windows unsuitable for winter, because then moisture condenses on the glass. There is no doubt that the having a peephole or two in a hive adds very agreeably to its value for amateur bee-keepers, and, to meet the wishes of such, we have had straw hives constructed with windows. It is not every one who would like to lift out the frames as often as is necessary for an inspection of the state of the colony, nor perhaps is it 
advisable to be often thus meddling. The windows have also a very neat appearance. We have hives with one, and some with two and three windows; of course a little extra expense is incurred where these are made, but that is not objected to by those who approve of the additional convenience. The crown-board (if a straw top can be called by that name) has, like the hive, a frame of wood all round, and a square piece of wood in the centre, with a two-inch hole; this hole is for the purpose of administering food, in a mode to. be explained hereafter. A circular block of wood, four inches in diameter, closes the opening.

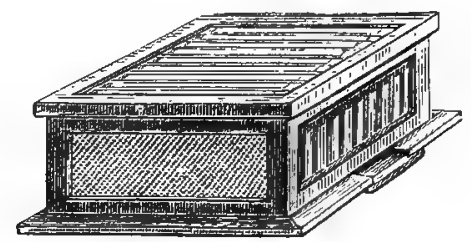

3. GLAsS.-Some bee-keepers like to be able to make a full and daily inspection of the hive; we have therefore prepared a few hives, constructed of wooden frames enclosed on all sides and on the top with window-glass. The dimensions are precisely the same as those before mentioned, and allow the same number of bars and frames (ten). The crown has a round hole cut in the glass to admit of feeding. The four sides are constructed of double glass, to preserve the bees from variations of temperature. We cannot, however, re- 
commend this hive for a winter residence for the bees; we should prefer lifting the combs out and placing them in a straw hive of similar construction, to pass through . the ordeal of the winter season (Chap. V. $\S \mathrm{xx}$.). Such a hive is an object of much interest, as in it the whole commonwealth of bees is exposed to view; and it need not be obscured from daylight, provided it be protected from sun and rain. All the external woodwork can be stained, varnished, or made of polished mahogany; so that the appearance of the glass frame hive is extremely neat, and much approved of.

\section{$\S$ X. NEIGHBOURS' NEW FraMe HIVE.}

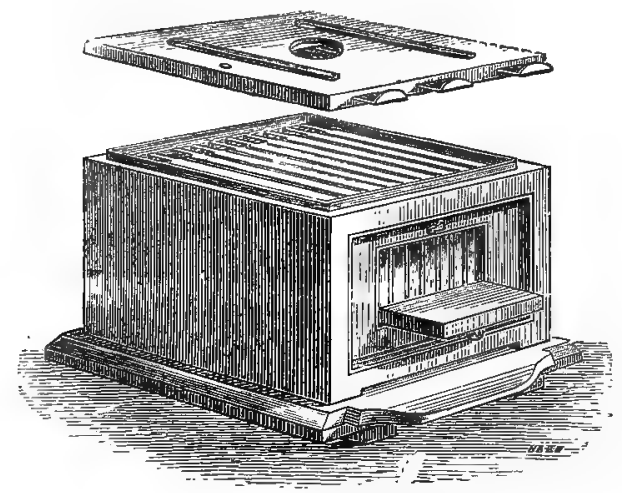

I. WooD.-Since the former editions of this work were published, several alterations and improvements have been made. We find, in the first place, that a deeper hive than the Woodbury is desirable for the better con- 
centration of heat, and also to admit of more honey being stored above the brood, so that the food shall be easier of access to the bees in winter. Our new frame hive measures accordingly twenty-one inches from front to back, sixteen inches in width, and twelve in height, thus allowing the sides to be constructed of the original breadth of the planks, viz., eleven inches (the other inch being made up by the thickness of the floor-board). The frames, of which there are nine, are ten inches deep and thirteen wide; they rest on strips of zinc, which prevent the bees from propolising them down so firmly, and, as the outsides of the hive are so enlarged as to leave galleries from side to side beyond the ends of the bars, there is easy access allowed to the fingers in removing. Another noteworthy improvement is the addition of a "dummy frame," which is merely a thin piece of board of the same size as a frame, and whose use is either to contract the dimensions of the hive according to the population, or to make room by its removal for the extraction of the first comb.

The frames are held firm and kept at their correct distances apart by means of small staples, and a slit is formed lengthways for the insertion of impressed wax sheets or guide-strips cut from these. The crown-board rests on the thin edge of zinc, in order that it may be replaced more quickly, with less danger of crushing a bee than on a broader surface. There is a feeding-hole in the centre of the board, which in some hives is closed 
by a zinc slide running in an opening cut out of the wood, and in others is covered by a wooden block. In the more highly finished hives two long openings are cut for admitting bees to the super. Two slides for each opening are supplied-one pair being of plain zinc for closing them entirely, the other with slits cut of threesixteenths of an inch in width for the purpose of queenpreventers (see Chap. IV. $\$$ xvii.). The supers are similar, but not so deep, and have eight frames instead of nine; they are, however, frames, and not mere bars as ordinarily. The sides and top are of glass, with baize. lined shutters.

A hive intermediate between this and the Philadelphia (s xii.), and which may be called "The Cottager's Improved Frame Hive," is shown inside the opened cover on page 179. It has a straw crown-board and a larger window, and is designed to admit a zinc adapter with queen-preventing perforations; in other respects it is identical with the above hive.

2. Straw.-The figure overleaf exhibits "Neighbours' New Straw Frame Hive," with super attached. It is of exactly the same size and construction as the foregoing. There is a straw crown-board with feedinghole in the centre, and two slits of zinc with queenpreventing openings as above. The supers of the straw hive are made of its own material, but have three windows instead of one. The advantages of straw for hivesare described under the Woodbury straw hive, above. 
3. Glass. - A representation of this same hive in glass, with its super, is given inside the opened cover figured

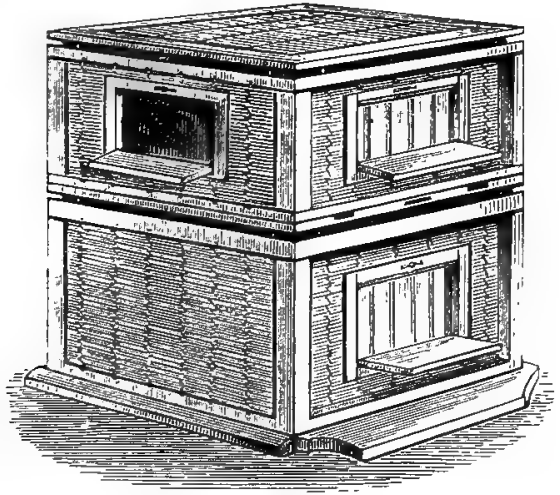

on page r77. Nothing need be added here, as the construction is the same with that of the wood hive. See the description of the Woodbury glass hive in the previous section for general remarks upon hives of that material.

\section{$\S$ XI. NEIGHBOURS' COTTAGER'S FIRAIE HIVE.}

This is a simpler and less expensive hive than the one just described, being without windows or a dummy, and with wooden crown and floor boards. In other respects it is the same, and is thus suitable for persons with small means, or who may wish to purchase in large numbers. Almost any kind of super may be adjusted to this hive, but those specially adapted are the frame super and our 
divisional and sectional supers, for all of which see the article on "Supers" (Chap. IV. \$vi.). To admit of
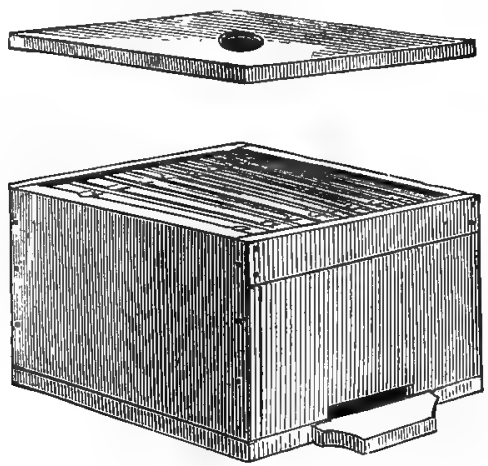

their addition the crown-board must be removed, and a zinc adapter with queen-preventing openings substituted.

$\S$ XII. THE PIILADELPHIA FRAME HIVE.

Our frame hives hitherto described have facilities for extracting the movable combs at the roof of the hive; with the present one the frames are drawn out at the sides as well as above. This is manifestly a great convenience, as it obviates the necessity of removing the supers when an examination of the combs is required to be made in the midst of the working season. The hive, cover, and stand are all in one, and the side-flap falls down, as it does in the cover shown on page 175 , and the loose glazed side, by removal, serves as a dummy, allow- 
ing each comb to be withdrawn without risk of scraping the next. The cover, it will be seen, opens at one side,

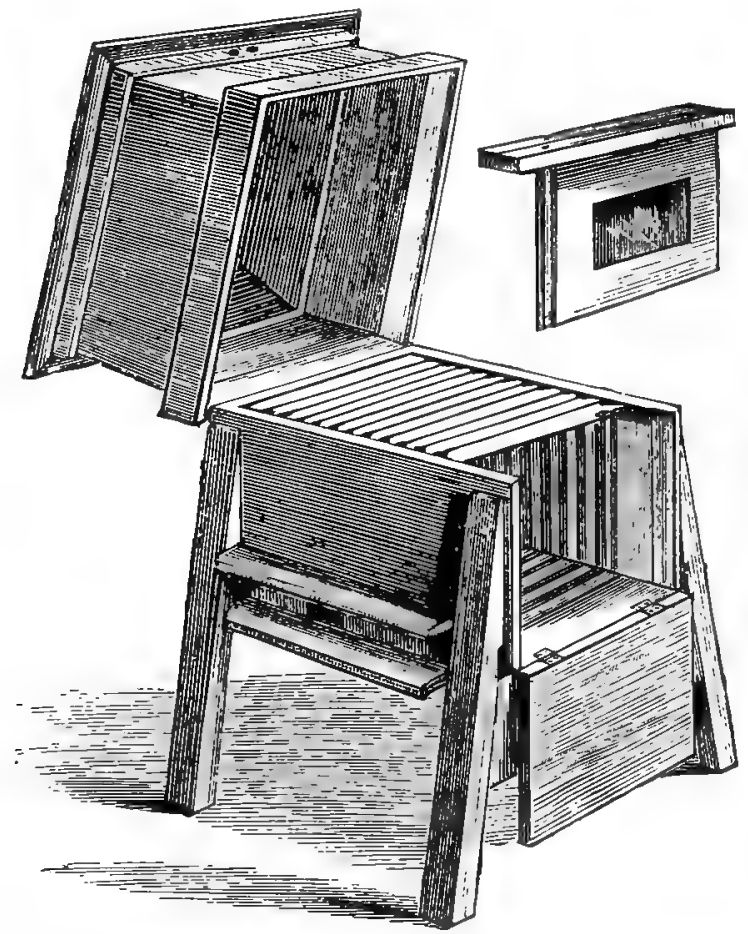

as does the stock hive. The floor-board draws out on the plan adopted by Mr. Cheshire.

There is a straw crown-board with a feeding-hole, which in summer is replaced by a queen-preventing zinc 
adapter perforated all over with circular holes too narrow to admit the queen or drones. The whole space over the frames is then covered with our small sectional supers (Chap. IV. $\S$ vi.), which, by means of the numerous perforations, are completely seasoned to the bees' taste with the same scent as the hive itself. The hive with its cover is complete without any further protection from the weather, and it carries its own stand. It was very highly commended at the Alexandra Palace Bee Show.

\section{S XIII. CHESHIRE'S FRAME HIVE.}

In its general principles and inner structure this hive differs very little from the one last described, with which in outward appearance it is still more closely identical; but the walls of the stock hive, when made of wood (for they can also be had in straw, if the apiarian so prefers) are constructed double, with an airspace between, with a view to modifying the variations of temperature. The upper part of the outer woodwork is a cover to the supers, and opens on a hinge at one side. Within are two of Lee's bar supers, placed one upon the other, the upper of which is to be first supplied, and the other added from beneath when the first is partly filled.

The stock hive usually contains eleven of the regularsized Woodbury frames, besides the dummy. Admission is given to the super by means of slits in the sides of two of the five planks constituting the crown-board, and 
when the super is away these two can be shifted to the ends, when the slits will come outside the hive. The entrance-hole is ten inches in length, but is provided with shutters for narrowing or closing it. The alightingboard in front of the entrance is grooved in order to let off wet or moisture. The entire floor-board draws out to allow of cleaning.

\section{\& XIV. ABBOTT'S NEW FRAME HIVE.}

Mr. Abbott's new hive is distinguished for the large size of its frames, which are sixteen inches long by ten deep. There are eight of them, besides two dummies. The honey-board is in three portions, with a round hole in the centre for feeding, and two slits for giving admission to the supers, which are Lee's. This divided crownboard rests close upon the bars of the frames, and a quilt should be placed over it in winter. The stock hive is of straw, and carries its own cover and stand. Its dimensions are two feet wide and three high.

Mr. Abbott has previously constructed some cheaper hives, but cheapness was made too exclusively their object to allow of their becoming sufficiently serviceable to be recommended.

\section{$\S$ XV. THE STEWARTON HIVE.}

The Stewarton hive (also called the Ayrshire hive) is so ofter spoken of, and in such favourable terms, by 
bee-keepers, that we deem it necessary to give it a place here, and to supply some explanation of its construction and management. We consider this especially needful, as some of the principles of its management are so imperfectly understood that many mistakes are made, and also because, for the convenience of bee-keepers, we keep a supply of these hives on hand.

The name is derived from their having been first brought out at Stewarton, in Scotland; and they are still made so well, and at so moderate a price, in

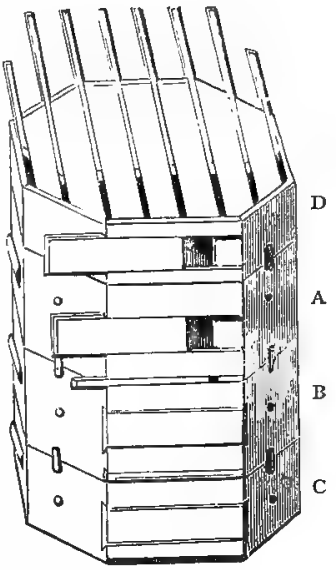
that country, that London workmen are unable to compete in their manufacture. Our supply is therefore from that source; so that, with a little addition for carriage, the price approximates that of the makers themselves, affording a convenience to many of our apiarian friends in being able to obtain these hives in London.

Our illustration shows the four boxes set up when the hive is complete. We will suppose that the beginner has just received the four octagonal boxes detached, with the bundles of grooved slides. About one-half of these are short pieces, or pegs, termed sectional slides, but similarly cut to the longer ones; these are to fill up the openings 
where the full slides are not put in, or are required to be withdrawn, as hereafter explained. He will find himself in possession of four boxes so neatly dovetailed on the bevel, that, if he be of a mechanical turn, he will not only be surprised at the way in which they are put together, but also at the price for which they are offered. Three of the boxes, A, B, C, technically called "body boxes" are precisely similar, each being fourteen inches in diameter and five inches and a half deep inside. Nine bars range along the top of each box. These are not movable, but are designed to induce the regular building of the combs. Between these and beyond the outer ones are ten narrow slides, the slides and bars being grooved to fit nto each other, so that the top is completely covered as if with a crown-board. In the figure the slides are shown as partly withdrawn. The fourth box, $D$, is the depriving box or super; it is only four inches deep, but the same in diameter as the others. This being the honeybox, it is furnished with seven wide fixed bars instead of nine, because, as stated at page $18_{3}$, bees construct deeper receptacles to contain the honey than for breeding in : thus, should the queen go up into this compartment, she may find the cells are too much elongated to enable her to reach the base when her body is inserted for the purpose of depositing an egg. The honey is thus kept pure, and the thick comb has a more massive, richer appearance, and that which not unfrequently mars the quality of a super-viz., cells that either contain brood or have been 
bred in-is prevented. Each box is furnished with two small windows, back and front, closed by sliding shutters, by which opportunity is afforded for inspecting the progress made, and also for ascertaining when the cells are filled and the box may be taken away.

Each of the boxes A, B, C, is furnished with an entranceway four inches wide and half an inch high, a wooden slide either wholly or partially closing it as required. When at work the bees need only one entrance open, and that at the lowest box. The long slides before mentioned are pushed into their respective receptacles from the back of the hive to close the openings between the bars; those of them that are shorter will be seen to belong to the sides of the octagon, and their ends are cut angular to suit the form of the box. A little examination will suffice to show the right allotment of the slides, the appropriation of which may be said somewhat to resemble the putting together of a child's puzzle.

The box в must be left open at the interstices that correspond with the box A, placed above, the little openings being closed by the insertion of the ten sections of slides, thus leaving free communication inside with the upper box $\mathbf{A}$, and admitting of no outlet for the bees except at the entrance. When the four boxes are placed above each other, the structure measures twenty-two inches high.

The Scotch carpenters send no floor-board, and no covering or roof for the top to shoot off the rain; they evidently expect that the purchaser is provided with a 
shed or bee-house of some kind, and also with a floorboard. Should the apiarian, however, not have these necessaries, we can supply the deficiency.

The sides of the boxes are furnished with wooden buttons, which, when turned round, keep each box exactly in its place one above the other; there are also projecting irons or screw heads for tying the two boxes A and $\mathrm{B}$ together preparatory to hiving the swarm, also for weighing; or if the boxes stand out exposed, all may be thus secured, to prevent their being blown over by high winds.

In putting the hive into use, take the two boxes A. and $\mathrm{P}$, made one by the junction before mentioned, with complete access from one to the other inside by the free communication afforded. Shake the swarm in just as .with a common cottage hive.

If the weather be favourable these two boxes will be nearly filled in ten days. To get the full advantage of the Stewarton hive the first year, put two swarms into two body boxes, $\mathrm{A}$ and $\mathrm{B}$. Allow the bees to remain there till they have nearly filled the body boxes with comb, which (with this increased number of workers, and in favourable weather) should be from five to ten days. Two swarms are seldom procurable the same day so as then to be joined together, and even if they were there is a doubt whether greater progress may not be attained by hiving one swarm a week or so earlier than the other, so as to build comb and raise brood ready for the reception of the new comers. 
The second swarm should be hived in the third body box, C, and placed close to the boxes A, B, and at dusk these last are placed on the top of the box c. The entrance being open in the lowest box, that of the central box, B, should now be closed with the slide. The top slides of box $\mathrm{C}$ must be withdrawn and the interstices pegged with the sectional slides. In the course of the night the second swarm will ascend and join the other, thus becoming one family. In the morning one of the queens will probably be found thrown out in front.

The box $\mathrm{C}$ is then to be removed, and the entrance slide of box $\mathrm{B}$ withdrawn. Should all the bees not have ascended, the removal may be deferred until later in the day when many of them are dispersed gathering honey. The object of removing the box $\mathrm{c}$, is to restrict the room so that the work of comb-building may be carried on more rapidly, and the bees be sooner ready to work in the super box D, placed above. They may be allured into this by fixing small pieces of worker guide-comb, of pure white colour, on the centre of each side bar. If, however, a box of honey with neatly made, straight, and quite regular comb be desired, a piece of this guidecomb must be fixed to the centre of each bar of the seven. If guide-comb be unobtainable, strips of the impressed wax sheets or artificial comb (hereafter described) will be found excellent substitutes.*

Having satisfied yourself, by peeping in at the windows, * The body boxes may be prepared in a similar manner. 
and from symptoms at the entrance, that the original boxes are well filled, place your prepared honey-box on the top, draw a slide at each side of the middle box to afford communication, and insert the little pegs. It is not well to withdraw the slides in the middle, because the queen is then far more likely to ascend. Bees may more readily be induced to work in the supers if the junctures are covered with gummed paper to preserve warmth. When you notice that the bees have fairly commenced work in the honey-box, and are likely to keep to it, a second and afterwards other supers may still be added, the new one being always placed uppermost; in all cases the remaining box $c$ must be added below the stock, which will afford additional room and prevent swarming, exchanging the entrance to the newlyfurnished box and sliding in pieces of wood to close the aperture of that above. Supers and nadirs may in fact be added -in fine seasons and with first-rate management -till there are eight or ten boxes in the pile.

Should the bees begin making comb in the bottom box, draw two more slides for freer access into the super, as there will then be little risk of the queen ascending, having so much range for egg-laying in the three lower boxes.

In very fine weather a good swarm or stock will fill a honey-box in the space of two weeks; but a much longer time is usually occupied. The process of taking the honey differs very little from that ordinarily followed in 
removing supers (Chap. V. $\$$ xiv.). The super box is disconnected with a spatula and twine; then drawing out one or two top slides, the bees are smoked or blown with bellows to cause them to make their exit.

Before winter sets in, the box $\mathrm{c}$, if in use, may be removed, and the comb it contains (if well filled) be used for consumption; if the comb be empty, let it remain carefully guarded from moth and other insects, as it will be invaluable next season. Empty comb may be thus preserved by tying or pasting a piece of stout newspaper closely round the bottom, and keeping the box in a dry place. Feeding, when required, may be liberally pursued by withdrawing two slides and supplying a bottle or other feeder.

The chief value of the Stewarton supers consists in the boxes being shallow, so that the combs are more likely to be well filled down to the base; the bees will also commence work more readily in such than in loftier compartments. This is a great advantage with supers, particularly when required to be sent to a distance, as there is less likelihood of the combs breaking down. For the same reason, when the weather is hot and the rays of the sun fall on the hive, the combs might part from their foundations if there were no intermediate bars, which is now the case in the stock hive, composed as it is of two boxes. If these two boxes were in one, the depth of each comb would be twelve inches; and, when filled with brood and honey, would probably weigh ten pounds. 
This is a great weight to be supported in hot summer weather, when the wax is softened by the heat. Another distinguishing feature that the Stewarton hive possesses is the use of the box $\mathrm{C}$, which, by giving increased room as the season advances, prevents what is often an annoyance to the apiarian, viz., a late swarm - too late to be of any value, and impoverishing the stock by a division of its numbers, thereby perhaps impeding the completion of the super. A further advantage of the box $c$ is that it induces the bees (who frequently hang in clusters about the entrance) to carry on their work instead of remaining in enforced idleness.

An accomplished apiarian who writes much in the Horticultural and Bee Fournals under the title of "A Renfrewshire Bee-keeper," and whose descriptions and management of the Stewarton hive render him an authority on this mode of bee-keeping as well as on the subject generally, says the only fault he has to find with the Stewarton hive is the fixity of the bars. With a modified hive used by him they are held in position with half-inch brass screws; thus all are movable, instead of being fastened with nails as in the original Stewarton. In each of the three body boxes are four bar-frames from end to end of the parallel sides; the two combs on either side of these are attached to movable bars, but these have no frames, as there would be a difficulty in making them to suit the angle. If it is requisite to withdraw the bars, they may be easily disconnected from the sides 
by passing down a knife. These boxes are one inch deeper than those of the ordinary Stewarton. We must say we do not consider that there is quite the same facility for extracting combs as with other movable comb hives described in these pages, but this may be an element of success-it possesses the opportunity without the facility. Many indiscreet bee-keepers are tempted to disturb their bees a great deal too much.

The writer had the pleasure of paying this gentleman a visit when in Scotland last autumn, and saw his apiary, also some remanets of the store of wonderful supers he took from his hives last summer-specimens indeed of good bee-keeping, and of the golden maxim worthy of all imitation, "Keep your stocks strong."

\$ XVI. THE. LANARKSHIRE HIVE.

In outward form this hive is much like the first bar-frame hive introduced to English apiarians by $\mathrm{Mr}$. Tegetmeier, who about eighteen years ago was secretary to a now defunct apiarian society the head-quarters of which were just outside London at Muswell Hill. This gentleman adapted the Stewarton slides to a square barframe hive, so that no crown-board was needed, just as is here provided by the ingenious I-anarkshire bee-keeper. One of Mr. Tegetmeier's hives may be seen at the Bethnal Green Museum of Science and Art. From some cause it did not come into very general use. 
The stock hive we are now describing measures sixteen inches and three-quarters from front to rear, and seventeen and a quarter from side to side, within; the height is nine inches and a half, and it contains eleven frames and one division board or dummy. Each of the frames is fitted with a false bar, which is intended to be under the bar proper; by taking a frame and pressing this bar out, an arrangement will be found for enclosing and holding tightly fixed the impressed sheets of wax for guides. 'The ends of the frames rest in the front and back of the hive; the top edges of the latter being deeply grooved along their centres to reduce the bearing surfaces, so that there may be less danger of crushing a bee when the frames are placed in position. These are now kept apart, and the spaces between are closed by wooden slides as in the octagon Stewarton hive; thus the advantages claimed by Scotch apiarians are here to be found in a square bar-frame hive. The sides and lower ends of the frames have projections which touch and keep each other steady, so that the combs are not so liable to be pressed together.

The super is four inches deep and equal in diameter to the stock hive, and is furnished, like it, with false bars, which have slits for inserting those infallible guides, the impressed waxen sheets. These are surmounted with another row of movable bars with the Stewarton slides between as before explained.

The back of the hive has a circular revolving disc of 
wood of half thickness let into it, in which are three three-quarter inch holes covered with perforated zinc, so that ventilation may be given or not. The alightingboard is made to slide in and out in grooves beneath the floor-board, which arrangement is convenient for transit of the hive to the moors or anywhere else. The entrance is opened or closed by means of sliding shutters, one on each side.

Outside covering from the weather is needed, and this we are also in a position to provide. This is beyònd doubt an ingenious useful hive, and how so much labour can be bestowed and yet the hive cost so little is a marvel.

\section{§ XVII. NEIGHBOLIRS' UNICOMB OBSERVATOKY HIVE-OUTDOOR.}

The unicomb hive here represented has many advantages over similar hives as previously constructed. The illustration shows the interior divided into six compartments; these are six Woodbury frames. The inner sash opens, to admit of hanging up the frames on the notches prepared for them. The width of the hive between the glasses of the, sashes is just sufficient to admit of one thickness of comb, with space on each side for the bees to pass and repass between the glass and the comb. Any one possessing a Woodbury box or straw frame hive can readily commence a unicomb, and as readily put the combs and bees back into the square hive again. 
The outside shutters on each side are composed of venetian blinds, admitting daylight, but obscuring the

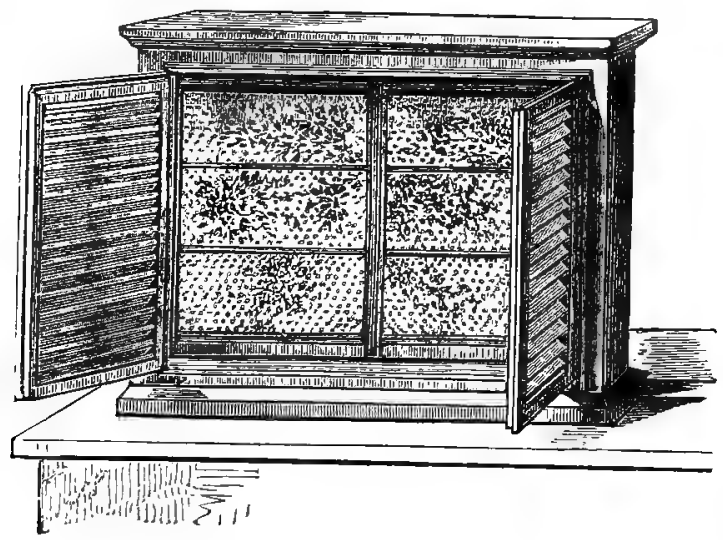

rays of the sun. There are two iron wheels, the one fixed to the bottom of the hive, the other to a stout board running along its entire length; on these two wheels the whole structure turns. In the centre of the floor-board there is an opening, with a passage-way running underneath, so that the bees' entrance is in no way affected by the position of the hive, which revolves to suit the convenience of visitors inspecting it. Should the queen, with her attendants, not be visible on one side, the other side of the comb can be brought into full view, and examined with the same facility as a picture, or as articles are inspected in a shop window. Thus the sovereign mother, the drones with their aimless movements, and 
the crowd of ever-busy workers, either building their combs or storing honey, may be always seen, as presenting a veritable tableau vizant.

Another improvement that we have made upon $\mathrm{Mr}$. Woodbury's pattern is that of adapting to admit the frames and this has necessitated an increase in size. The outside dimensions are nearly three feet square and seven inches deep from back to front. Provision is made at top for feeding, and for working two small flat-top glasses for deprivation, which are protected by the weatherboard. An alighting-board is placed at the centre, close under the entrance. The hive can, however, be placed indoors, when it must be adjusted to the window-sash like the indoor unicomb in the next section.

- In the summer of 1863 we had ample proof of the success of this hive during its exhibition at the annual show of the Bath and West of England Agricultural Society at Exeter. We selected six combs, and packed them in one of the square box Woodbury frame hives, and, on arrival at Exeter, placed them in the unicomb. That being fixed against the boarded side of a shed, we found the covered way a great convenience, and it answered remarkably well; the bees did not seem to be inconvenienced by having to travel through so long a passage. A glass covering admitted a full view of the little labourers as they crowded in, and the sight of them very much enhanced the interest of visitors examining the hive. 
Since the time before mentioned we have exhibited bees at the meetings of the Bath and West of England Agricultural Society at Bristol, and of the Royal Agricultural Society at Newcastle in I864. On both occasions further proof was given that this hive admirably answers the purpose intended, and it afforded pleasure to many thousands of visitors. We also exhibited one of these hives in our collection at the J'hiladelphia Exhibition of 1876 , and in their certificate of award the jurors direct special attention to the unicomb hive with venetian blinds as allowing the admission of light to the bees whilst the sun's direct rays are excluded.

The unicomb hive may be stocked in two ways. The bee-keeper may either select the comb upon which the queen is found, and put it into the hive, and so form an artificial swarm as directed under that heading (Chap. V. $\$$ vi.), or he may take six brood combs, and by that means stock the unicomb at once. The former plan is, perhaps, the more advisable, because new comb has to be built within the five frames; for in this case five empty frames must be put in. It is a better plan still if artificial combs are placed in each frame, so as to afford an interesting opportunity of watching the formation of the cells therein. The combs are sure to be dark in colour when taken from a stock hive, and new combs, being whiter, have a better appearance in the hive. 'The comb upon which the queen was introduced may be taken away after the artificial swarm has made combs 
within some of the other five frames; when the queen is on one of the new combs, opportunity may easily be taken for opening the hive and removing the old dark comb, which, with the unhatched brood, may be deposited in any square hive that needs strengthening.

If the possessor of a square Woodbury frame hive wishes to start a strong unicomb colony, and does not object to appropriating the stock, he must take out of the Woodbury hive any six combs on the frames, and put the unicomb in its place so as to receive all the returning bees that happen to be abroad; the remaining combs can be inserted in any other frame hives in which there may be room. We have had this hive in operation, stocked in such manner, and found it to answer remarkably well. On a lawn, placed on a suitable ornamental stand, it formed a pleasing and instructive object.

In unicomb hives there is considerable difficulty in keeping the bees alive through the winter, but where the combs are removable, this can be avoided by the transfer recommended in Chap. $V . \S \mathrm{xx}$. In some degree to moderate the variations of temperature we have used treble glass with a space between each square; greater warmth is thus obtained, and the view is not intercepted. Opportunity should be taken for cleaning the unicomb hive when empty. 
§ XVIII. NEIGHBOURS' UNICOMB OBSERVATORY

\section{HIVE-INDOOR.}

This hive is well adapted for those persons who are desirous of having the opportunity of closely examining the workmanship of the industrious and interesting inmates. It is particularly intended for a window recess or an indoor apiary, and will also be found an interest-

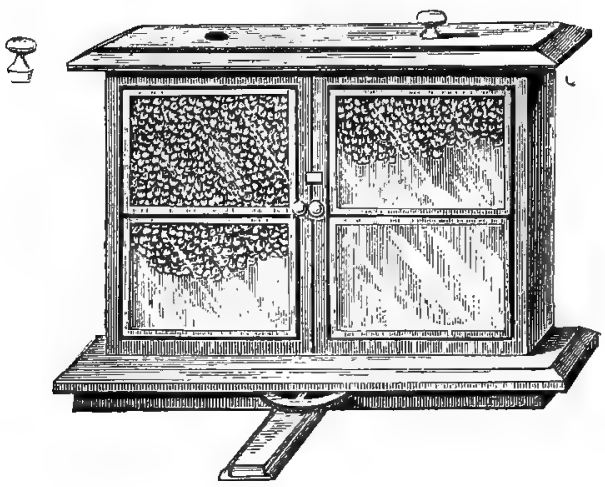

ing addition to the greenhouse. Bees cease to appear disturbed when exposure to the light is continuous, and this discovery enables the bee-keeper to obtain a full inspection. The hive should be screened from the direct rays of the sun, which would worry the inmates, and be otherwise prejudicial. An aperture should be cut in the sash corresponding with the entrance to the hive, through which the bees may find egress and in- 
gress, without being able to gain access to the apartment, as described under the "Ladies' Observatory Hive" (page I20). As the hive is now made to revolve on a wheel like the preceding, this passage must extend. eighteen inches within the room to enable the revolution to be made clear of the window. The passage may be glazed over. The process of stocking is identical with that in the last section.

Although this hive is constructed of double glass, to keep up a more uniform degree of warmth, still, from the cold nature of that material, and the close contact into which the bees are brought with it, it is advisable to place flannel against it on the outside. Such precaution is found essential if the bees remain in this hive during winter, and very much adds to their comfort on cold nights at most periods of the year. In the daytime, in summer months, the hive being of double glass, the whole may be fully exposed to view, and if the temperature of the apartment in which it stands be kept up to 60 degrees, this extra care will not be needed.

At the annual International Exhibition of $x 873$, at South Kensington, we had two of these hives in full operation, an opening being made so that the bees had full access to the pasturage of the Horticultural and other gardens of the neighbourhood. Among the many visitors whose delight it was to watch the hidden working of the hives thus laid bare for inspection was His Grace the Duke of Sutherland, and he commissioned us 
to place one of these unicomb hives at the window of an anteroom adjoining his library at Stafford House, St. James's, which we accordingly did, the bees having an open flight over his own garden and St. James's Park, as the entrance faced that way. For a time this was an unfailing source of interest and gratification to His Grace and his visitors; but unfortunately a reverse came over the spirit of our dream. The hive was without the venetian blinds, thus depending on the windowblind being carefully drawn down when the sun was shining. An oversight prevented this being attended to one day as usual: it was on the occasion of the visit of the Shah of Persia to Stafford House, when the servants were so much orcupied that the secluded room which the bees were in was wholly neglected. The, consequence was that the rays of the burning June sun so distressed the bees that they hung out in clusters, the queen among them, at the outside entrance; the combs were at the same time melted, and fell from their foundations, and the brood was all ruined by heat; in fact, the whole hive became a wreck. We managed after some trouble to save the bees, but His Grace was so disheartened by the catastrophe that, for fear of its repetition, though much to our disappointment, he declined re-stocking the hive.

At the Paris Exposition Universelle of $\mathrm{I}_{55}$ we also exhibited a hive of this description in full working order. The bees left London on the $5^{\text {th }}$ of July of that year, 
and were placed in the Exposition on the following morning. An entrance was made for them through the side of the building, as before explained. Our bees had no national antipathies, and they immediately sallied forth to their "fresh fields and pastures new" in the Champs Elysées, the gardens of the Tuileries, the Luxembourg, etc., whence they soon returned laden with luscious store from French flowers.

The Jurors of the Exposition awarded us a prize medal for beehives. A prize was also adjudged to us for the hive here described at the Crystal Palace Show in 1874 ; while a variation that we have made--consisting of four half-unicombs fixed crossway like the sails of a windmill-obtained a like award at the Alexandra Palace Bee Show in 1876 .

The unicomb observatory hive is one which might have been suggested by the lines of Evans :-

" By this blest art our ravishel eyes behold

'The singing masons build their roofs of gold,'

And mingling multitudes perplex the view,

Yet all in order apt their tasks pursue.

Still happier they whose favoured ken hath seen

Pace slow and silent round, the state's fair queen."

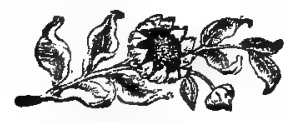




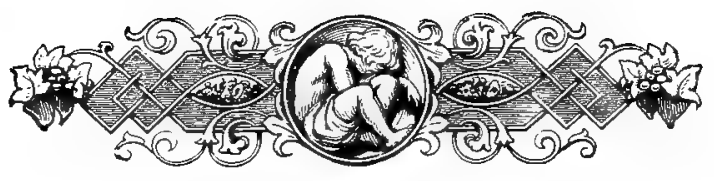

\section{CHAPTER IV.}

FITTINGS AND APPARATUS.

I. BEE-HOUSES.

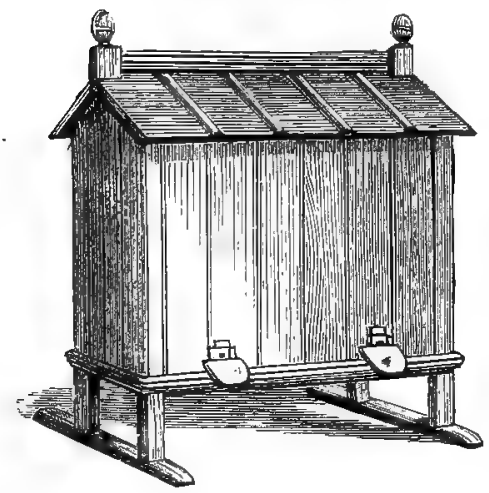

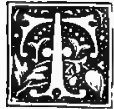

HERE is no contrivance for protecting hives from the weather so complete as a bee-house: one which also admits of an easy inspection of the hives ranged therein is especially convenient for lady bee-keepers. We here present a front view of one designed for only two hives.
} 
The folding doors behind the bee-house have only to be opened, and the hives are at once exposed to full view; then, by raising the upper hive or cover, the glasses may be deliberately inspected without molestation from the bees, and the progress made by the busy multitude may be watched from day to day. Under the roof on each side are openings to act as ventilators, to allow the heated air to escape. With the sun shining on the house, and no escape of this kind, the temperature would become that of an oven.

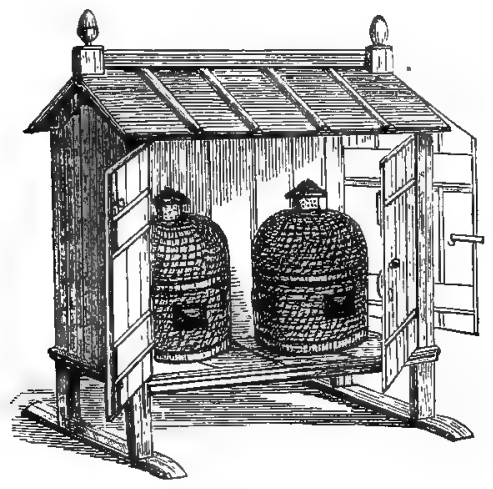

Here our illustration shows the back view of the beehouse, the interior being furnished with two of our improved cottage hives. Two suspended weights balance the top hives which cover the glasses; the cord for each runs on pulleys, so that the covers can be easily raised 
and as easily shut down again when the inspection is finished. We may here remark that it is not well to keep the glasses long exposed to full light and view.

The front of the bee-house being closely boarded, a passage-way is contrived for the bees, by which they have egress and ingress to the hives without being able to gain access to the house. The hives must be kept close to the front boarding of the house, to prevent the opening of any crevices which the bees might mistake for the entrance to their hives, and so find their way into the house. The front view of this bee-house shows the ordinary contrivance for giving admission; the sliding zinc entrances may also be advantageously fixed, as shown in the woodcut of the bee-house to contain twelve hives. The bee-houses we, furnish have a lock and key.

Care must be taken to keep the bee-houses free from spiders and other insects. In some districts ants are numerous and troublesome. The plan we recommend for excluding them is to put some pitch round the four supports of the bee-house, or, better still, strips of loose flannel or other woollen material that is absorbent, which have previously been soaked in lamp oil. We use sperm oil, as being the slowest-drying oil we know of. A piece of string will keep the flannel close to the wood, and then neither ant nor other insect will pass up; so that by this simple means the hives may, so to speak, be insulated and placed beyond their reach. As 
the oil dries up it can easily be renewed. We have found this an effectual renıedy against these insidious enemies of bees.

Where economy of room is a consideration we fit up bee-houses with a double row of hives, one above the other. Our illustrations show respectively the front and back of a house of this kind for twelve hives, having an

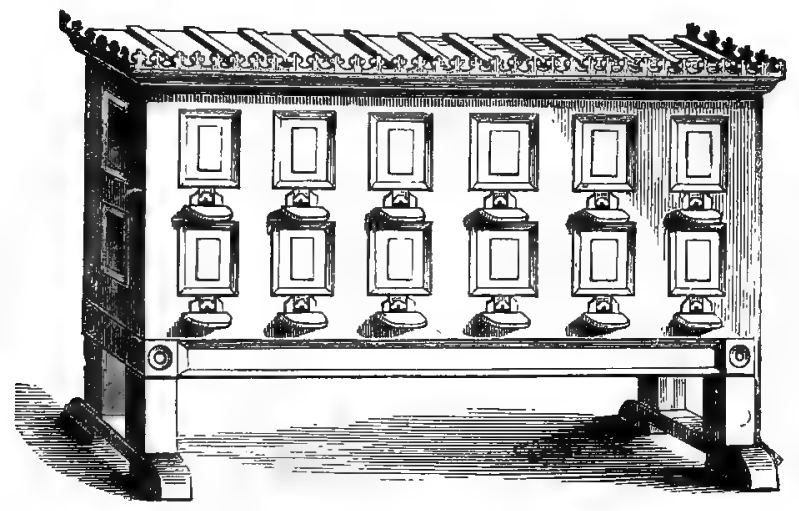

ornamental zinc gutter to prevent the wet from dripping on to the alighting-board. When a number of hives are thus together we colour the alighting-boards differently, so as to provide the bees with a distinctive mark by which each may know its own home, and not wander into its neighbour's house. Bees readily enough receive a honey-laden labourer into a hive; but if the wanderer be poor and empty it will be promptly repulsed, and 
may have to forfeit its life for the mistake. Queens returning from their wedding trip are liable to mistake their hive if there is not a noticeable difference between the entrances. A queen entering a hive already possessed of a fruitful sovereign would be certain to be killed, and the loss to her own hive is a serious one. Hives are often made queenless from this cause, and

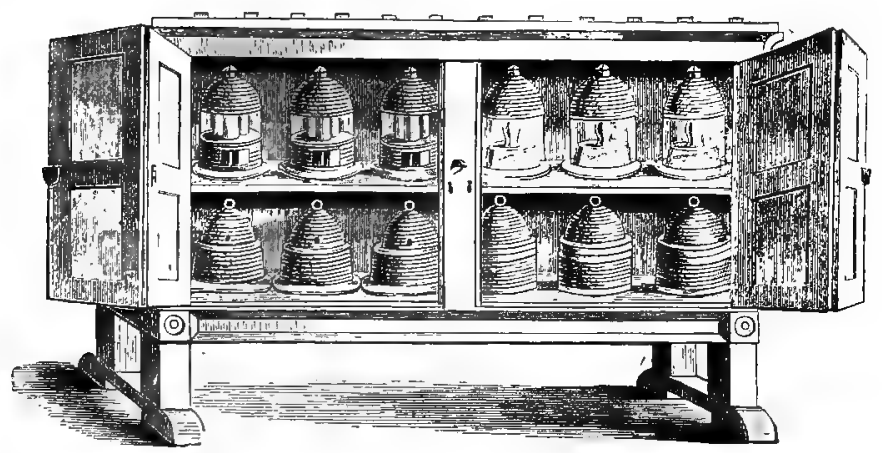

thereby reduced to utter ruin, the bee-master perhaps attributing his failure to something altogether different.

In lieu of houses an economical stand can be provided by driving two rows of posts into the ground, one row about twelve inches behind the other, and nailing upon them rails two inches wide and thick. The hives may stand upon these, with eighteen inches between them for space for performing operations. But there is less fear of jarring the other lives when the stands are separate. 


\section{§ II. ZINC COVERS.}

The annexed illustration shows the ornamental zinc cover, and renders but little description necessary. It represents one of our improved cottage hives upon a stand. Three clumps of wood must be driven into the ground, and the three iron rods supporting the covering made fast to them with screws; there are screw holes in the feet of the iron rods for the purpose. When thus secured but little fear need be entertained of its being blown over by high winds.

In the roof two pulleys are fixed, so that, by attaching a cord, the upper hive covering the bell-glass supers

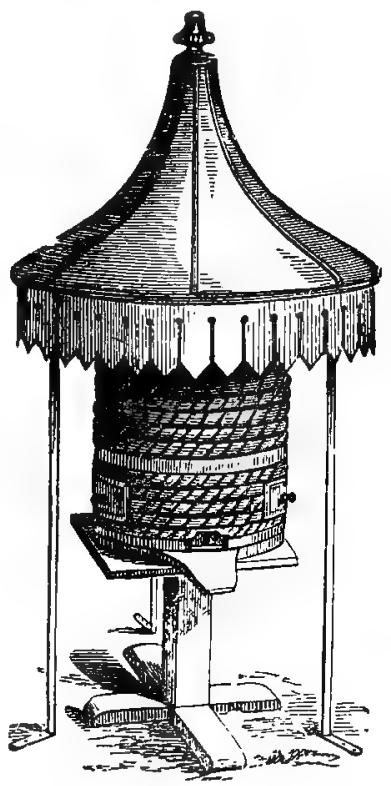
may be raised with facility for the purpose of observing the progress made by the bees. Directions as to the mode of fixing the pedestal will be found above (page I 18 ).

The ornamental zinc cover will form a pleasing object in the flower-garden when placed in a suitable position 
on the grassplot. It is painted green; the iron rods are

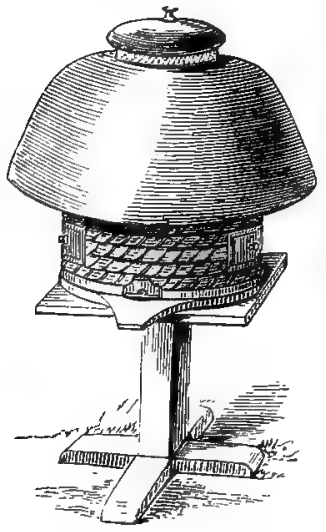
of such a length as to support the roof at a convenient height from the ground.

Our next figure is that of a simple and inexpensive covering for any cottage straw hive when exposed in the garden. It fits close on to the upper hive, coming sufficiently low to protect it from sun and rain, without obscuring the whole hive.

These covers are painted green-a colour that is generally preferred.

\section{$\S$ III. WOOD COVERS.}

A loose outer case completely enveloping the hive is found very useful. Such covers are made in various forms, some to drop over the hive in detached portions, some in a single piece, and others hinged; some, as we saw in the last chapter ( $\$$ xii., xiii., xiv.), constitute a part of the hive itself. Ample room must be allowed for opening these, both at the side and behind, remembering that from the latter position all operations must be conducted. The cover and stand will require painting, or else staining and varnishing, which looks perhaps better; the hive itself, if not exposed to the weather, will not need this. When removing or replacing the covers, 
care must be taken not to enrage the bees. Covers formed with opening shutters will obviate the necessity of frequent removal.

The accompanying figure shows a simple form of cover for dropping over a hive. Its width is twenty-six inches, depth twenty-two, and height in middle nineteen.

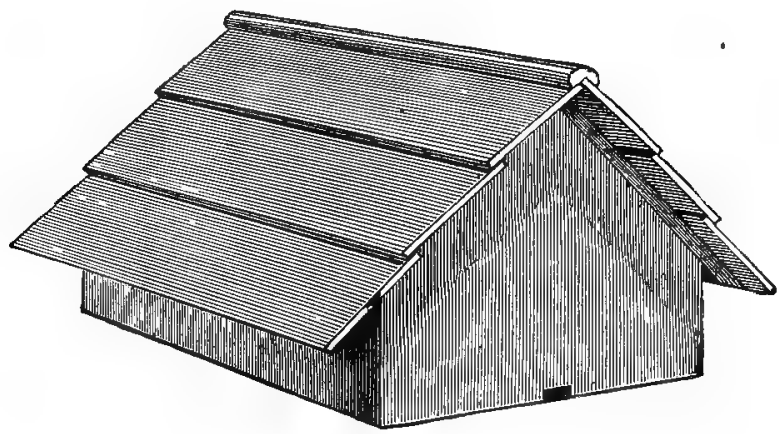

Cottagers often use straight stiff thatching straw, sewed together; this contrivance is termed a "hackle," and has a pretty appearance, particularly if a number of hives are in a row. Care has however to be exercised that mice do not make the cover a resting-place. Mortar is often used for fastening round the hive at the bottom, but this is a bad plan, as it forms a harbour for insects; the wooden hoop fits so close as to leave little necessity for anything of the kind. The wooden cover just described is more especially constructed for our frame hive (page I 42), but it may be used for any hive that it will fit over. 
Our next cut represents the Woodbury cover, which is formed in three portions (the roof, the super-cover, and

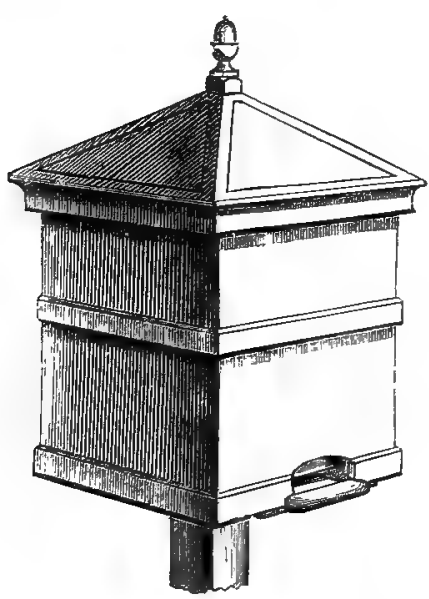
the stock -hive cover). It has an upper and a lower door, or rather shutter, behind. The whole can be placed on a pedestal as here shown. As this cover requires to be lifted off in pieces, and is liable to be blown over by the wind, it is not so convenient as those figured below, which open on linges and are selfsupporting.

We next give two representations of one of our more elaborate covers, showing it respectively from behind as opened and in front as closed. 'The former exhibits the cover with one of our new frame hives (Chap. III. $\S \mathrm{x}$.) within it, and two divisional supers upon the hive, the roof being formed sufficiently high to accommodate these. The cover is thus made to open near its vertical centre, and is held back by a chain. The flap behind falls down on opening the top to allow of inspecting the stock hive without drawing it out of the cover. In the front there is a portico for protection to the entrance, and wood slides work in grooves to narrow the opening in 
winter or other lad weather. The total height of the cover and stand is forty-five inches, the width twenty-

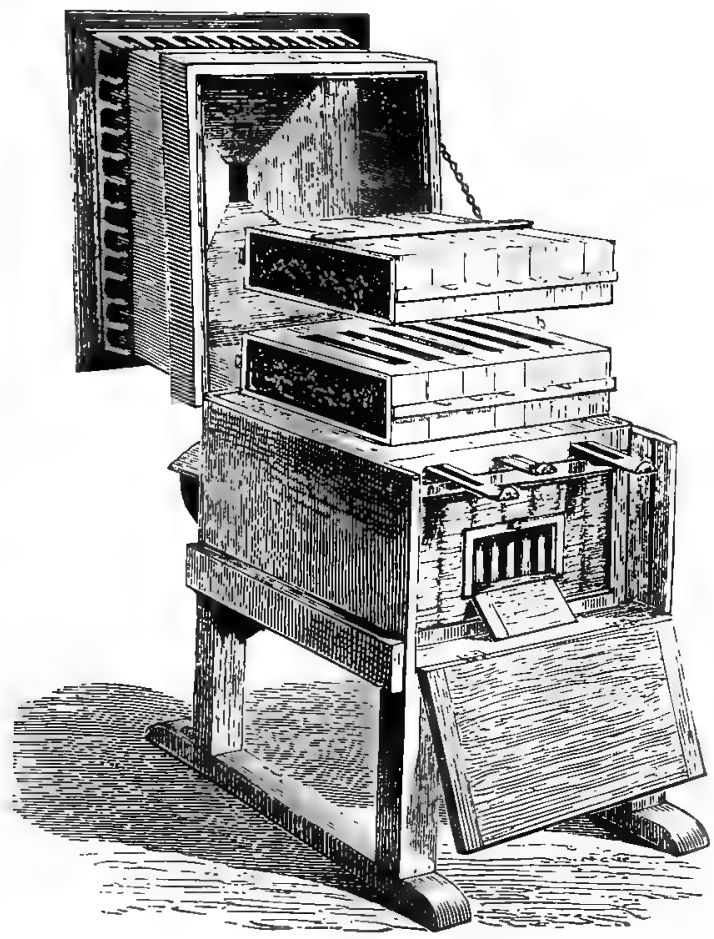

two, and the depth twenty-six. The outside of the whole is grained and varnished. In the figure tollowing it will be observed that the hinges are placed in the 
front; while underneath these the portico, slides, and alighting-board are clearly shown, as well as the sloping roof-in short, the general appearance of the whole structure as it actually stands in the apiary.

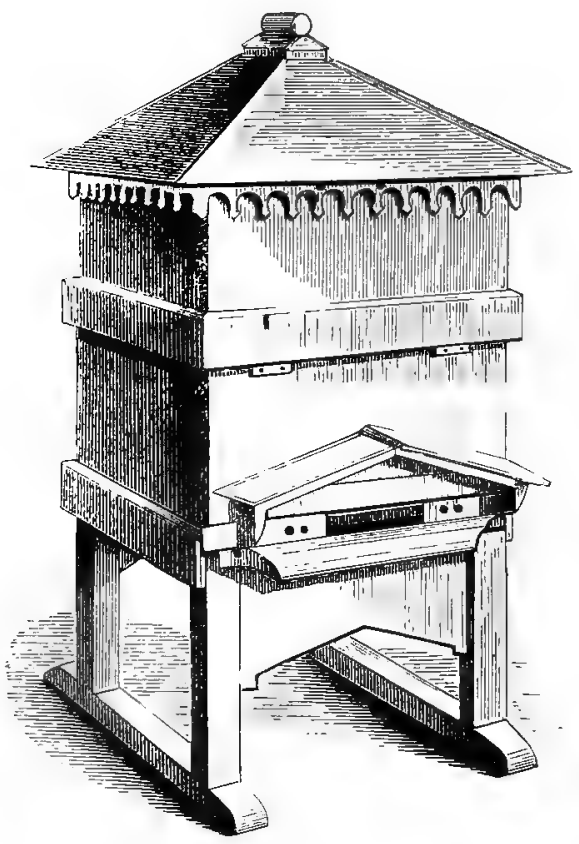

The next pair of views represent another very useful cover, but it has the objection of being bulky and more costly. The open figure exhibits, within the cover, our 


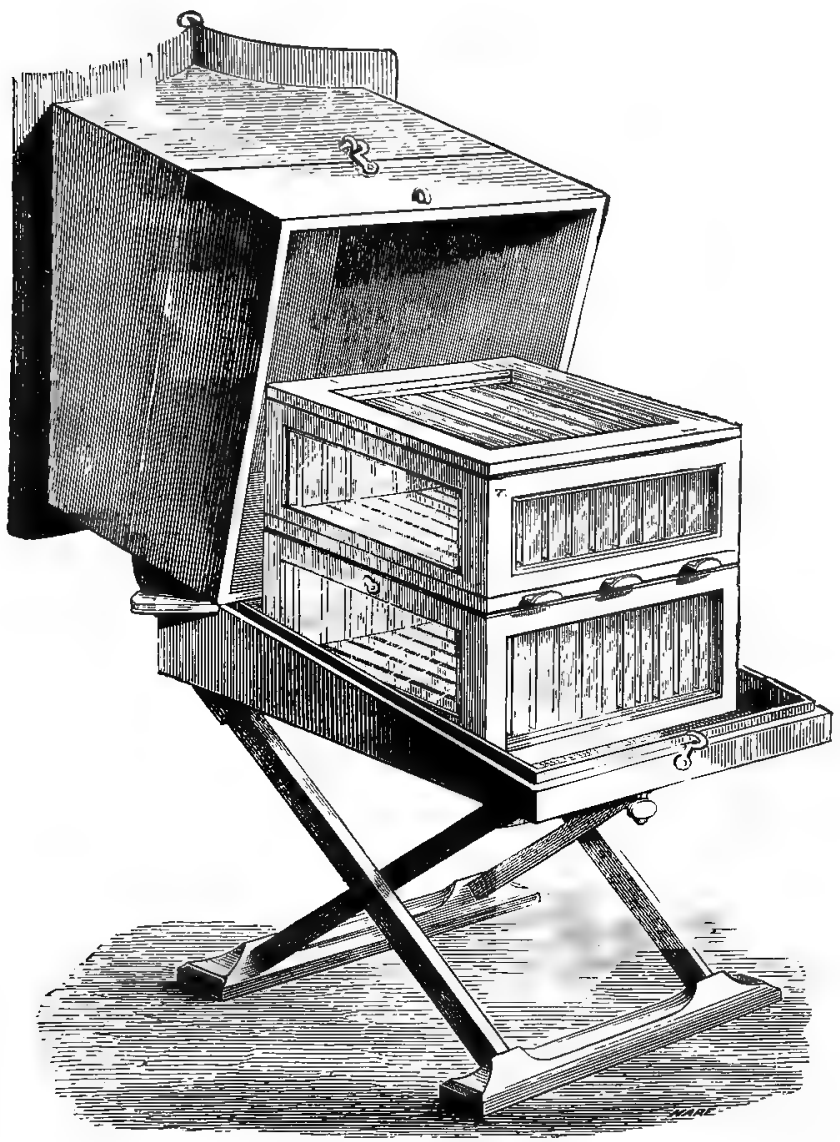


new glass frame hive and super (page $\mathrm{r}_{42}$ ). The hinges are formed with movable pins to enable the cover to be

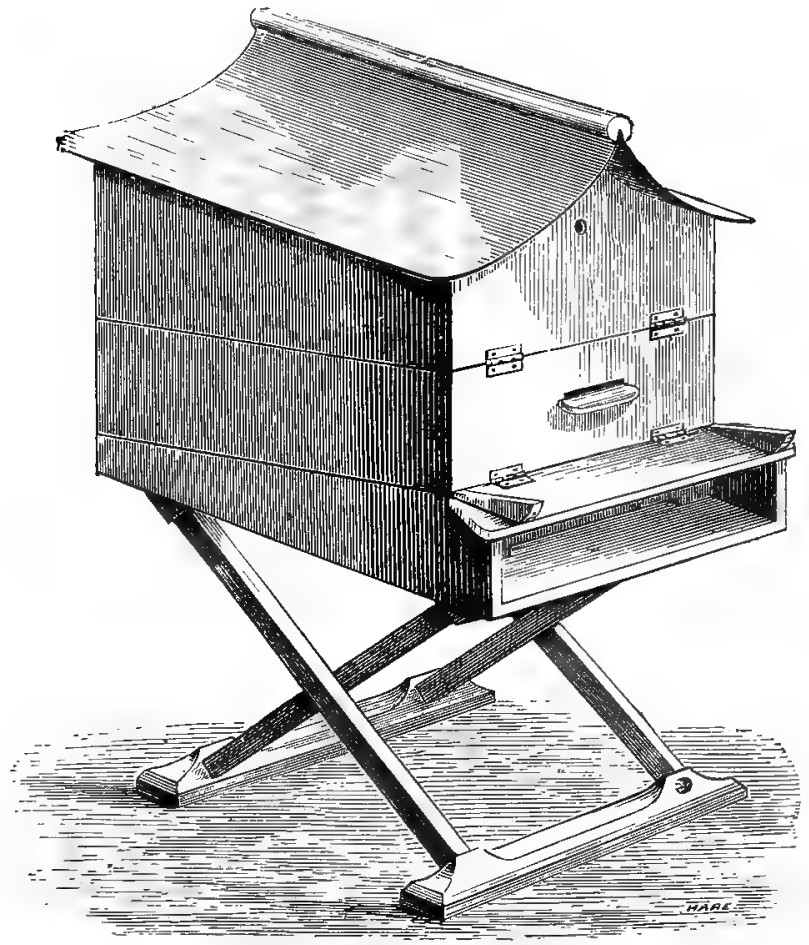

totally removed from the stand. An opening from the outside conmunicates with the stper, so that the bees can find exit without passing through the stock hive. 
The flight-hole can be narrowed as in the previous instance.

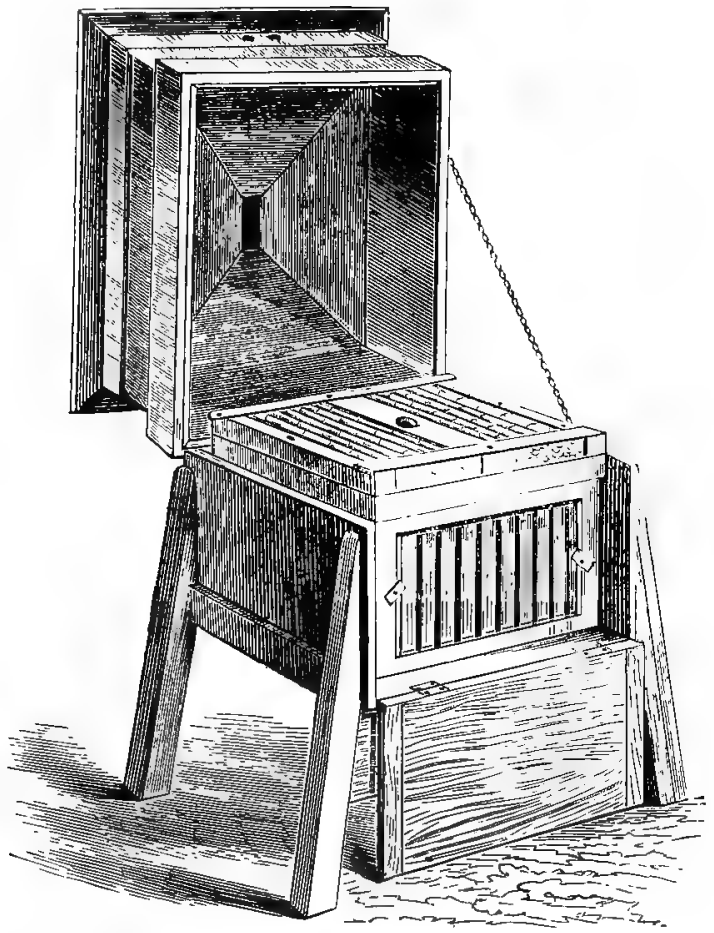

The annexed cut shows a new cover of simple and inexpensive construction. In it any of our frame hives can be placed. The stock hive here exhibited is the one 
referred to on page I4I, as "The Cottager's Improved Frame Hive." The advantage in having the stock hive independent of the cover and stand, and on its own floorboard, is that the hive is more easily stocked and more manageable in other respects than those that have hive, stand, and cover all in one, as is the case with the Philadelphia, Cheshire's, and Abbott's hives.

The drawing shows the outward construction so well that little further explanation is needful.

\section{$\S$ IV. QUILTS.}

Some American apiarians recommend the use of a quilt in place of a crown board, as admitting of ventilation to the hive and thus allowing the moisture to pass off. Quilts are made of some soft woollen material or a piece of carpet. Care must be exercised that the maggots of other insects do not find a home underneath, or a hotbed will by that means be provided for bees' worst enemies.

\section{$\S$ V. BELL GLASSES.}

In describing the stock hives of wood, straw, and glass, allusion has frequently been made to the depriving hives technically called "supers." The simplest form of these consists of the straw caps, represented at pages 108 - IIO, and next to these will come those to which the 
above heading applies. Of the stricter bell-form, rounded at the top, we have three sizes :-
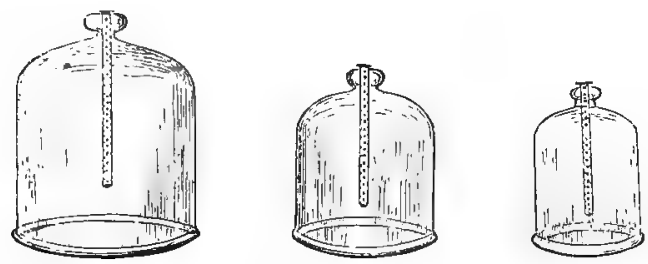

To contain rolb., Io inches high, 7 inches wide.

To contain 6lb., 7 inches high, 5: inches wide.

To contain 3 lb., 5 inches high, 4 inches wide.

These bell glasses are used in the lives before described. The largest is for Nutt's hive; the middlesized is for our improved cottage hive; the smallest glass is so very small that it is not often used, and we do not recommend it. Bees will generally fill a middlesized glass quite as soon as one so small as this.

The next figures exhibit what are known as "Taylor's
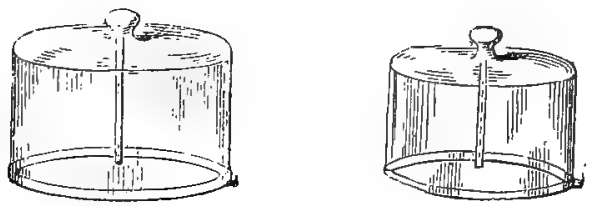

Glasses." They were introduced by Mr. Taylor, and are recommended as preferable to deep narrow glasses. The drawings will show that they are straight at the 
sides, flat at the top inside, with a knob above to take hold by, through which is a half-inch opening to admit a ventilating tube. The larger, to contain perhaps twenty pounds, is six inches deep and thirteen inches wide; the smaller, five inches deep and nine and a half inches wide.

The late Mr. J. H. Payne, of Bury St. Fdinunds, author of the "Bee-keeper's Guide," introduced another

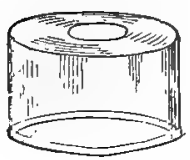
glass, called "Payne's Glass" accordingly. It has a three-inch hole in the centre, the purpose of which is to tempt bees to produce additional and larger stores of honey. It is to be used as follows: When a bell glass (which must be smaller in diameter than Payne's) is half or quite filled, raise it, and place Payne's glass over the hole of the stock hive, with the filled glass on it, over the three-inch hole. The bees will bring their combs through, and thus Mr. Payne found that they would store more honey than if the bell glass were removed and another empty one put in its place.

The "Flat-topped Glass" is a super to be placed on

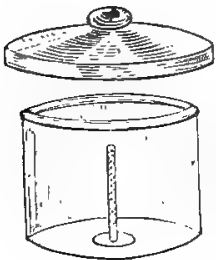
the hive in a similar way to the bell glasses already alluded to. It has the advantages of being straight at the sides, flat at top, and without a knob; so that when filled it may be brought on to the breakfast table, inzierted, on a plate. The glass lid shown in the figure forms a 
cover, and fits over outside so as not to interfere with the combs within. 'There is a ventilating tube as above. Dimensions, six and three-quarter inches in diameter, and five in height.

\section{$\S$ VI. BAR SUPERS.}

To these we have already made considerable allusion under the various hives to which they are applied. They are often made of glass, but many are of wood or even straw. It is desirable that the combs in supers should be made thicker than those for breeding-the bees will in fact deepen their honey cells to almost any extentand therefore the bars are placed somewhat further apart than in stock hives, thus allowing of one or two bars less. By gradually widening the spaces between the combs these can be brought up, Von Berlepsch tells us, to four inches in thickness. With the shallower form of all the older supers the bars are without frames. The cut exhibits the "Woodbury Super," which is of glass,

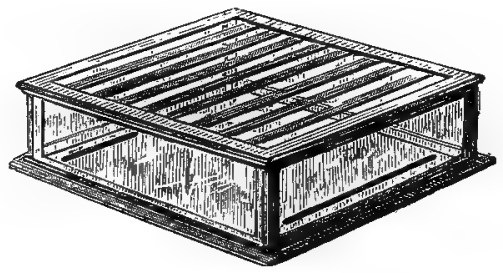

thirteen inches square and six deep, with eight bars to the ten of the hive. These can be either the Wood- 
bury ribbed bars, or flat ones with guide-comb attached. Lee's supers are similar, but they contain seven bars with four Stewarton slides for giving admission from one to the other when more than one super is used.

The next figure shows our "Frame Super," already sufficiently described on page I4I. It can be had as below, in glass with wooden framework, or in straw with three windows, as shown with the hive on page $14 z$.

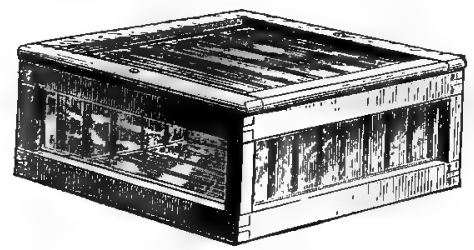

Next in order we give our "Livisional Super," to which a prize was awarded at the Crystal Palace Bee Show in 1875. It is composed of seven divisions or frames,

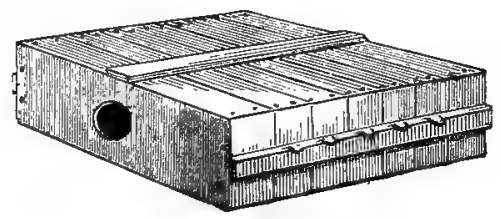

which are kept together by lateral strips of wood. Each division is intended to have one comb worked in it, rendering the contents of the super divisible without cutting the combs. As shown in the figure on page 175, 
this super is now made with whole-glass ends. From the same figure it will be observed that these supers are adapted for placing one above the other, passages being cut out of the top bar of the lower of the pair. Slits are cut for the insertion of strips of wax sheets.

Both in this super and the next it is desirable to provide against the admission of cold through the numerous interstices by keeping a warm woollen covering on the top and pasting paper over the divisions, which can easily be cut through when the super is filled.

Neighbours" "Sectional Super" is the last of our series.

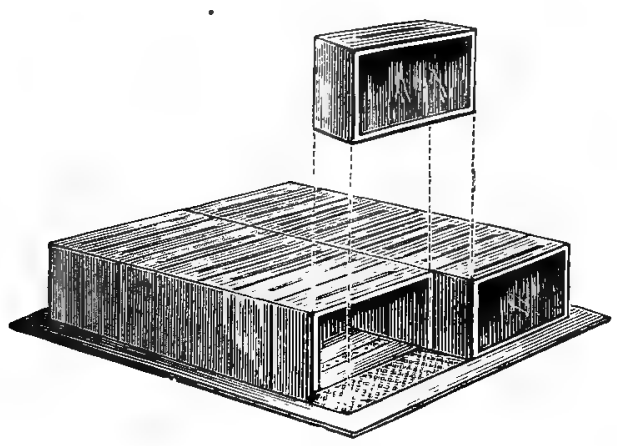

The attention of apiarians has been so much turned of late years towards a cheap and compact receptacle for honeycombs intended for deprivation, that we have introduced this last invention, which is very much on the same plan as the preceding, but the longitudinal divisions are again divided across, forming boxes, as shown in the 
figure. Each section is about two inches wide, seren long, and four and a half to five deep; it will contain about two pounds of honey in the comb. This is a convenient quantity for placing on the table or for purposes of presentation. The fourteen sections occupy the same space as the seven divisions of the preceding. Any number can however be used according to the size of the hive : the Philadelphia hive, for instance, has space for eighteen. Again, any single section can be removed when full, and another substituted.

Each section has a saw-cut in the crown for the insertion of wax strips. The queen-preventing zinc adapter can also be used. Observe the caution given in the second paragraph of the description of the divisional super, just above.

\section{§ VII. EKES AND NADIRS.}

We allude to these for the sake of explaining the terms, and as they are adjuncts sometimes recommended for temporary enlargement. They are further contrivances for the prevention of swarming, but they differ from supers in being added below instead of above the stock hive. Briefly, an eke is a half-hive so added, and a nadir an entire one. An example of an eke is sometimes met with when a common skep is cut horizontally in half, and the lower portion placed beneath an entire skep hive. For an instance of a nadir we have only to refer to the Stewarton hive. Ekes and nadirs give increased room to the bees, but 
they of course do not answer the purpose of supers in providing honey free from the admixture of brood.

\section{\$ VIII. IMPRESSED WAX SHEETS.}

These artificial partition walls for combs are sheets of genuine wax, about the substance of thin cardboard. They receive rhomboidal impressions by being pressed between two metal plates, carefully and mathematically prepared and cast so that the impressions are exactly the same size as the base of the cells of a honeycomb. An inspection of a piece of comb will show that the division of the opposite cells is made by a thin partition-wall, common to both. The substance of this is said to be only the one hundred and eightieth part of an inch, whilst the artificial ones we are recommending are between the thirtieth fortieth part of an inch, or more than four times the thickness of the handiwork of the bees themselves. It would, indeed, be vain to attempt to furnish them with sheets of wax at all approaching their own delicate fabric, and our sheets are quite as thin as they can be to bear the handling requisite for fixing them in the hives. We find, however, that the thickness is no disadvantage; the bees speedily excavate and pare the artificial sheet so as to suit their own notions of the substance required; then, with admirable economy, they use the surplus thus obtained for the construction of the cells. After a sheet has been partly worked at by the bees, it is interesting to hold it up to the light and observe the 
beautiful transparency of that part of it, contrasted with the opaqueness of the part not yet laboured upon.

This invention renders us independent of guide-comb, which is not always obtainable. It comes to us from Germany, where it has attained many years of success. At the International Exhibition of 1862 we purchased the metal plates or castings, so as to manufacture the impressed sheets with which we are now able to supply our customers; and after the careful trials we have made we have great confidence in recommending them. As will be seen below, however, we no longer advise insertion of entire sheets.

In the season of 1863 we furnished a Woodbury glass super with the wax sheets fixed to the bars in the way hereafter to be explained, and it was truly astonishing to mark the rapidity with which these sheets of wax were converted into comb. Receptacles were quickly madie ready for the storing of honey, and the new combs soon became beautifully white; for, although the artificial wax has a yellow tinge, yet, after being worked at and made thinner, it is as good in colour as ordinary combs.

If whole sheets are used-or, in the case of supers, half ones-perhaps the simplest plan for fastening them is to fix a strip of wood with brads to the under side of the top frame or bar; place the wax sheet against this, then wedge another strip close to it, and thus hold the wax sheet firmly in the centre of the frame, taking care also to make the second strip of wood fast with brads. This 
has however the objection that it slightly diminishes the space. The wax plates must not extend to the bottom of the frame; a space of at least one inch should be left for expansion, because the bees, in working the plate, stretch it down lower. Te also use a few pins firmly pressed into the frames, and long enough to reach the edge of the plate; for by fixing three or four pins on each side, both at the sides and at the bottom, the plate may be held in an exactly central position within the frame.

We are now disposed to make a great modification in the above directions, and, instead of using entire sheets of wax, we cut strips from them of about an inch in width, and place these in the bars as before, when they form an edged projection of half or three-quarters of an inch. We have found an objection to the entire sheets in the fact that they sometimes curl and break with the weight of the bees-so eagerly does a new swarm apply itself to work upon them-and thus become an obstruction instead of a help.

Strips of cardboard or wood shaving, dipped in hot wax or well besmeared therewith, may be substituted for the wax strips themselves. Where no slit is made for the insertion of either, the shaving running down the lower edge of the bar may be simply rubbed with hot wax, and the same purpose will be served. 
§ IX. COMB FOUNDATIONS.

This is an American attempt to improve on our impressed wax sheets. In the proffered assistance to the bees there is here some advance, for not only are the lozenge-shaped plates at the base of each cell more clearly stamped and defined, but the sides of the cells are slightly begun-so deep are the impressions that the foundations of the walls are actually laid.

Being quite a new invention, there has not been much time for fully testing it, but we find from American beekeepers that when used in large sheets there is the same difficulty as with our impressed wax-the bees will twist them. As specimens of work these comb foundations are certainly very commendable for appearance. The white ones seem too white to be of pure wax, and any substitute offered to bees has hitherto proved a failure. Mr. Baldridge, a frequent correspondent of the American Bee Foumal, speaks of the yellow sheets as far preferable to the pure white, but some that are made partly of paraffin he considers of little worth. Possibly the material of which they are manufactured may be made to suit the delicate senses of the bees. Until this is the case, hindrance rather than help in comb-building will be the result of placing them in the frames and sectional or other supers. The mode of fixing is the same as described for impressed wax sheets. 


\section{§ X. CHESHIRE'S GUIDE-MAKER.}

At the Exhibition at the Crystal Palace in I875, Mr. Cheshire exhibited and obtained a prize for a wax guidemaker, which is an ingenious contrivance. It consists of a plaster of Paris cast, with impressions taken from the metal plates before referred to (page 187 ). This cast is two inches in width, about the same in thickness, and eleven or twelve inches long. It rests in a shallow zinc or tin trough containing water to keep the plaster damp by capillary attraction. The plaster cast may first be soaked in water; then place against its side the top bar of the frame, reversed so that the centre of the under side lies even with the edge of the embossed cast. The wax (which must be genuine) is melted in an ordinary glue-pot; then with a clean paintbrush it is applied to the top of the plaster cast and exposed part of the bar. The wax immediately hardens on the damp cast and does not adhere, whilst the under side of the bar carries an embossed guide of sufficient depth to be an unfailing means of direction to the swarm in the building of straight combs.

When a large number of frames have to be prepared, this ingenious apparatus is a convenience; but for the ordinary apiarian we should advise procuring a few of the impressed wax sheets, cutting them in strips, and fixing without the mess and trouble which Mr. Cheshire's apparatus involves. 
$\S$ XI. BAR-FRAME HOLDER.

It is often a great convenience to have a rest at hand to lodge frames of comb on. The illustration shows

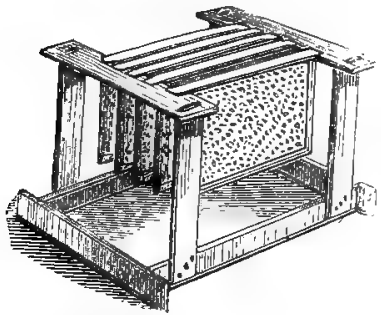
one that we have contrived, and which will accommodate twelve frames of almost any size. The two broad rests on the top may be set closer or further apart by loosening the screws which keep them firm. They are easily shifted and secured again by screwing up.

This stand is light in weight, so that it can easily be carried about as required. The frames of comb, with bees on them just as they are, are temporarily placed on the holder when an inspection of the interior of the hive is needful, and the combs can be returned to the hive in the same order.

§ XII. CHESHIRE'S TRANSFERRING BOARD.

This is a contrivance which will be found specially serviceable in transferring old stocks from one hive to another (Chap. V. $\S$ iii.). It consists of an inclined rest for the combs, composed of laths. of wood arranged like the teeth of a comb, so as to allow the honey to drain into the zinc receiving-frame underneath; it also admits the ready introduction of the tape or whatever is used 
for tying and fixing the combs in the new frame. The operator should place the board upon a table so that its front, or the upper edges of the inclined laths, face him as he stands.

\section{\$ XIII. HONEY-CUTTERS.}

Honey-cutters are used for removing comb from boxes and glasses without damaging it. The flat-bladed knife is for disconnecting the combs from the sides; the hook-shaped one is to be applied to the top or horizontal part of the box or glass. We

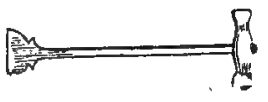
have recently introduced a knife with both these blades, one respectively at each end.

\section{§ XIV. THE HONEX-EXTRACTOR.}

The first notion of extracting honey from the combs by centrifugal motion was the result of an accident. A son of Major von Hruschka, a bee-keeper in Germany, tied a piece of honeycomb to a string, and in play whirled it round the inside of a pail. Finding that the honey was ejected and the cells of the comb left dry, the idea was suggested to Herr von Hruschka of constructing a machine for the purpose, and this he soon afterwards did. The first honey-extractor was a wooden vessel with something like a broomstick working on a pivot in the centre; to this axle, provision was made for attaching a framework to carry the combs, and the 
centrifugal motion was obtained by winding coils of string round the upper part of the revolving shaft, which

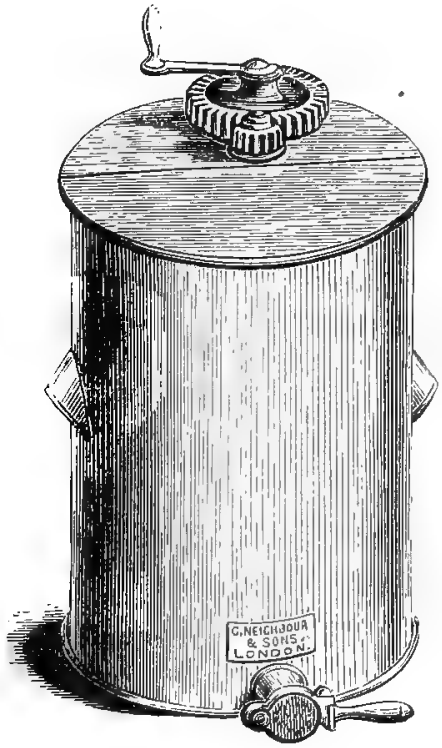
was thus put in motion by pulling the string sharply in the way a boy's humming-top is made to spin round.

This answered for a beginning; but with the opportunity of employing machinery it was soon found that many improvements in the construction might be made. For instance, it was apparent that the extractor should be constructed of metal, because the wood absorbs so much honey that it will soon become sour in warm weather, however carefully attended to and cleansed. The honey-extractor shown here consists of a metal reservoir with a treacle tap at its base to draw off the liquid honey. In the middle of this reservoir is a castiron spindle, with arms or projections to receive two metal wire cases, one on each side; in these cases the combs are placed, whether in frames or not. Motion is given by turning the handle, which with the aid of a 
cog-wheel causes the spindle to revolve at great speed. The machine is mostly used for frames of combs taken from stock hives whilst the honey-gathering is at its height.

When the frame is removed from the hive whilst at full work, the bees have to be shaken or brushed off with a feather, and those cells that are sealed have to be uncapped by shaving the waxen lids off with knives, of which there should be two, one to be kept immersed in a vessel of hot water, whilst the other is used until it becomes cold, and so alternately until the required work is accomplished. The knife being warn very much aids in slicing through the wax as near the top as possible, and prevents tearing the tender comb. This must be done carefully so as to disturb the form of the cells as little as possible, and not to touch the brood cells, from which honey cells are easily distinguished. The frame is placed in one of the wire cases, and a second may be treated in the same manner and dropped into the extractor. A few turns of the handle eject the honey by centrifugal force, and a little practice will inform the operator of the requisite degree of speed, though some honey is more tenacious and takes a few more turns than. other. When on examination it is found that the honey is gone out of one side, the cases will then have to be reversed, and a few more turns will clear the cells on the other side. The frames should now be returned to the hive for the bees to refill, and two other frames of comb may take their places in the extractor, and so on until all 
the combs in that hive suitable for extraction have been operated upon according to the wish and judgment of the manipulator. Prior to commencing this operation, a little smoke should be blown into the hive and an examination made lest the queen should be too summarily shaken off the comb; she must be quietly transferred to another if the one she may be on is required to be placed in the extractor.

During the gathering season it is astonishing how quickly these emptied cells will be refilled with honey, and not unfrequently the queen finds in some of these unoccupied receptacles timely provision for her otherwise contracted accommodation for depositing eggs; thus breeding goes forward at an astonishing rate. Much is written about the value of comb, and by this contrivance the labour of the bees in building it is saved. There is no doubt but that this instrument is of great service to the bee-keeper when judiciously applied, ${ }^{*}$ and since the introduction of the movable combs it has formed an important adjunct thereto. For no invention has the apiarian cause to be more deeply indebted than for the "Mel Extractor" of Germany, improved upon as it has been both in America and in this country. Even if there were less sale for extracted honey, the extractor would be found at certain times of great value to every bee-keeper.

* This machine is not of much service for extracting honey from combs made in supers, the cells of which are mostly too soft to bear operating upon. 
In the award at the Philadelphia Exhibition, special notic of commendation is recorded of our honey-extractor.

\section{§ XV. CHESHIRE'S NUCLEUS HIVE.}

The object of nucleus hives is explained below in the section on "Queen Rearing" (Chap. V. §vii.), and they render services in the process of artificial swarming, in maintaining a supply of young mothers, or in Italianising an apiary. Mr. Cheshire's contrivance is as follows : Certain frames in a regular hive are made to consist of two half-frames, each complete, but joined together in the top bar by a tongue in the one portion which fits firmly into an opening in the other, thus forming an ordinary frame except for the division down the middle. When a royal cell has been formed upon one of these compound frames, such frame is taken out of the hive, and the twin portions are then placed side by side in the nucleus, which measures only three and three-quarter inches wide inside, nine inches deep, and seven and a half from front to back. Its sides are constructed double in the same way as those of the Cheshire frame hive (page $\mathrm{r}_{45}$ ). In the nucleus hive it is necessary for the frames to be well covered up. Care must be taken that the queen was not upon either of the nucleus frames, but the other bees may be retained upon it. The older ones, however, will be sure to return to the stock hive, and their place must be supplied by shaking young ones off other frames on to a board in front of the nucleus. 
The royal cells may be obtained from any source, and artficially transferred to the divided frames, after which the frames must be placed in a stock hive for twentyfour hours for the bees to fix and repair the cells. Or, if more convenient, three or four such frames may be placed in the middle of a hive, and all stocked with eggs; the queen may be removed for a few hours, at the end of which a larger or smaller number of royal cells will be found to have been formed, and these in the middle frames, which should be the ones desired. The transferring process may still be needful, unless only one or two queens are wished for. The royal cells should be placed inside when the two parts of the frame are put together in the nucleus; there must however be only one such cell on each of these, as the first queen that is hatched will be certain to destroy the cells of the rest.

Further mention of the subject of nucleus hives will be found under "Queen-Rearing." They should be constructed with narrow entrances so as to lessen the facilities to robber bees.

\section{§ XVI. QUEEN-CAGES.}

These are small receptacles made of close wire or perforated zinc, just large enough to contain the queen with a few of her acknowledged subjects, and their use is on the occasion of her introduction to a new hivé. The new queen is by this means protected from the 
primal hostility of the bees, but at the same time so much communication is permitted as suffices to familiarise them gradually with her presence. It is one of the characteristics of the bee nature that, however distressed they may be at the loss of their old queen, and however eagerly at work to produce a successor, they will not usually receive such at once from an artificial source. They will, however, supply her with food even when longing to transfix her with their stings.

We have two kinds of cage for this purpose. One of them is a wire dome to be placed over the queen, when with a card carefully slipped underneath she can be kept secure until the hive is prepared to receive her favourably. It is nearly the same as Kleine's cage for protecting royal cells, as described under "Queen-Rearing" (Chap. V. $\S$ vii.). Another cage, devised and strongly recommended by "A Renfrewshire Bee-keeper," is flat in form and neatly made of wire net; it is two inches deep, one and a quarter wide, and three-eighths of an inch thick; the top is of the same material, and projects one-eighth of an inch all round as a flange to prevent slipping too far between the combs. The door consists of stronger wires reaching across' the bottom of the cage; these are fixed at one end, and have two more wires fastened to them at the other, which wires pass up at the corners and are brought out at the top, where a push with the thumb will cause the bottom to project open. Into this cage we consider there is more difficulty in intro- 
ducing the queen than into the other, as she has to be taken hold of with the thumb and finger and passed within the narrow opening; and though some of the cages are made with an entry-valve at the top, the risk of injuring the queen remains, in our opinion, greater than with the domed cage. The mode of procedure with each of these will be found described under "Introducing New Queens" (Chap. V. \$viii.).

\section{§ XVII. QUEEN AND DRONE PREVENTER.}

Much disappointment is often felt, when removing a super that appears well filled with honey, at finding

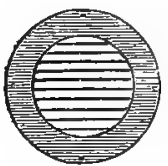
that brood, and not honey, is in many of the cells. In such a case the super should be replaced on the hive until such time as the brood has hatched out. The comb will be found to be discoloured, but there is no help for that. The fact of there being even a few cells so occupied is a great deterioration. Tlis little contrivance, however, excludes both the queen and the drones, the wires or strips of zinc being fixed too close together to admit of their passage, though wide enough for the worker bees. It is adapted for any hole that it will cover, but more especially for the openings in the tops of straw hives communicating with the supers. Some of our better-class hives are fitted with slides pierced in like manner, or else with sheets of perforated zinc to ensure the same end. 
The queen-preventer also serves a useful purpose in preventing pollen being carried into the supers, as the edges of the wires or bars act as scrapers upon the legs of the bees.

\section{$\$$ XVIII. BEE-TRAPS.}

The object of these is to clear supers of bees previous to taking the honey. There are several of them in use, but the principle of most is the same. Clutton's beetrap resembles one of the common round-holed mousetraps, but the bees have to pass out instead of in. Over the little circular hole a pin is hung perpendicularly, and permitted by wire staples to open far enough to allow the escape of the bee, after which it falls back and denies readmission. The super having been removed from the hive and inverted, the trap may be fitted into one of the sides of a box, which, without its lid, is then inverted upon the super, every opening being closed which could admit a bee from outside. The super is then darkened, when the bees within will make for the light through the trap. Mr. Cheshire and $\mathrm{Mr}$. Aston have also invented traps. Mr. Aston's has talc falls in place of pins.

\section{$\S$ XIX. DRONE-TRAPS.}

If the increase of drones grows into an intolerable nuisance a trap may be applied for their partial extermination. Aston's drone-trap is an ingenious contrivance, though we recommend its use only under limitations. 
It consists of a box to affix to the hive entrance, with an opening from the inside, but no means of exit except through perforations which admit only the workers; the bees are attracted into it by the light, while their proper flight-hole is darkened by a ridge over which they can just make their way into the hive. The drones are thus left in the box to perish. The objections which we have to the trap are-first, that the surmounting of the ridge must surely prove an impediment to the work of the bees; secondly, that the ridge obstructs ventilation; and thirdly, that should the queen stray into the trap, she will, unless promptly discovered, soon share the same fate with the drones. But if the trap be applied only for an hour or so at the part of the day when the drones are leaving the hive in the greatest numbers, it may then perhaps sufficiently effect its purpose and be free from any serious drawback.

\section{$\S X X$. BEE-FEEDERS.}

It has long been acknowledged that the best mode of feeding bees is through an opening at the top of the stock hive, as bees can thus take the food without coming abroad. Another important feature is the cleanliness with which liberal feeding can be accomplished; and few operations require more care than this does. If liquid sweet is left hanging about the hive it tempts robber bees, and when once the bees of an apiary have had a taste, there is no knowing where their depredations will stop. 
Even if no hives be completely destroyed, weakness from loss of numbers will be the portion of most, if not of all, the hives in the garden. The morals of our favourites are here a good deal at fault, for the stronger hives, when their inordinate passion is thus stirred up by the carelessness or want of knowledge of the bee-keeper, attack and prey upon the weaker ones. "To be forewarned is to be forearmed"-and "prevention is better than cure."

The "Bottle Feeder," as shown in the annexed figure, consists of a round or flat bottle placed in an inverted position over the feed-hole of the stock hive, and resting in a circular block, below which is a piece of perforated zinc. The following directions will show how it is to be employed: Fill the bottle with liquid

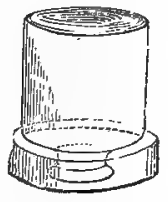
food; apply the net, affixed by an india-rubber band, over the mouth; place the block over the hole of the stock hive, and invert the bottle, the neck resting within the hole in the block: the bees will put their tongues through the perforations, and imbibe the food, thus causing the bottle to act on the principle of a fountain. The bottle being glass, it is easy to see when the food. is consumed. The piece of perforated zinc is for the purpose of preventing the bees from clinging to the net, or escaping from the hive when the bottle is taken away for the purpose of refilling.

Specially prepared pieces of vulcanite plate, pierced 
with holes in such manner as to give complete regulation to the supply of food, are much recommended by some apiarians. No net is then required, but as the plate is to be a fixture on the crown-board, the bottle should be inverted over a small shovel or some thin metal plate, which may then be withdrawn, leaving it standing upon the vulcanite. Occasional examination of the plate is however requisite, as the bees will sometimes stop up the holes with their propolis. We strongly recommend closely covering up this feeder with one of the middlesized bell glasses, should the regular hive cover not be sufficiently tight. When bees are not kept in a bee-house this is particularly needful.

The "Can Feeder" is our next form of an apparatus for this purpose. Much has been said about stimulating

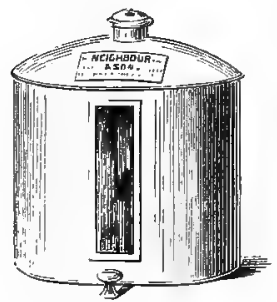
feeding-that is, administering food in such a way that there shall always be liquid sweets within the reach of the bees, and that they shall continuously be able to imbibe a little. In order to meet this requirement we have constructed a new feeder, which consists of a tin bottle or can, six inches wide by six high, with five small holes at the bottom, and closed by a sliding valve and a screw top. The can is filled from the top, with the valve closed, and when the screw top is made firm this valve is drawn back by moving the pin in front. The can is placed 
over the feeding-hole at the top of the stock hive, and the bees have access to it by small holes. This can is on the principle of a fountain : the screw top rendering it air-tight, the liquid only escapes as drawn down by the probosces of the bees. A glass side is let in to show when the feeder is empty. It need not be removed for refilling. The capacity of the vessel is over a quart. Its difference in form from the above renders it less liable to attack from robber bees.

Our "Round Feeder" is made of zinc or earthenware, eight inches across and three deep. The projection outside is a receptacle for pouring in the food. The bees gain access to the feeder through a round hole, which is placed either at the centre

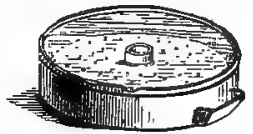
or nearer one side, whichever may best suit the openings on the top of the stock hive; it is in fact a tube which fits oyer the feed-hole in the crown-board, thus allowing the bees to rise through it above the surface of the liquid. A circular piece of glass, cut so as to fit into a groove, covers the feeder all over and prevents the bees escaping, whilst it retains the warmth within the hive, and affords opportunity for inspecting the bees when feeding. The feeders were originally made only of zinc; but some bee-keepers advised the use of earthenware, and a few have been thus made to meet the wishes of those who give the preference to that material. 
When the bees are fed from above in this manner, the feeder is kept at a warm temperature by the heat of the hive. In common hives cottagers feed the bees by pushing under the hive thin slips of wood scooped out, into which the food is poured. This plan of feeding can only be had recourse to at night, and the pieces of wood must be removed in the morning. By feeding at the top of the stock hive any interruption of the bees is avoided. For further instructions on this head, see the directions given for using the bottle feeder. Round feeders are of course entirely safe from robber attacks, being protected by the regular hive cover.

A variation upon this is "The New Round Feeder," which obtained a prize at the $\mathrm{r} 875$ Crystal Palace Bee

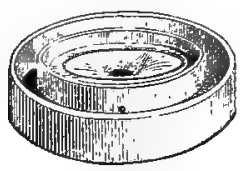
Show. It is made of wood, and holds more than two pounds of liquid food, which must be poured into the outer trough. The bees ascend through the centre as in the last case, and passing over the innermost ridge, which is rounded, they reach the inner trough, at which they imbibe the food without risk of drowning, as the sides are too contracted. A piece of window glass covers the top. The feeder is nearly ten inches in diameter.

\section{§ XXI. FUMIGATORS.}

The "Box Fumigator" is a tin case, somewhat like a pepper-box upon a foot. It is a simple adaptation of the 
fumigating apparatus described by Mr. Nutt, and is used in the following manner: Have a straw hive or other vessel ready that will match in circumference the hive intended to be fumigated. If the empty hive have a conical top it will not remain crown downwards without a rest; in this case it will be convenient to invert it on a pail. Having ascertained that the hive to be operated upon and the empty one in its reversed position

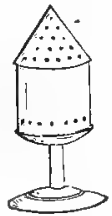
nearly match in size, take half a packet of the prepared fungus, fire it well, and place it in the box or fumigator; place this in the centre of the empty hive, then bring the occupied hive directly over, so as to receive the fumes of smoke. To keep all close, put a wet cloth round the junctures of the two hives. After a minute or two the bees may be heard dropping heavily into the lower empty hive, where they lie stupefied. After a little while the old hive may be gently tapped upon to make them fall more quickly. On removing the upper hive the bees from it will be found lying quiet at the bottom of the lower one, when the intended operation-of uniting different colonies, searching for the queen, or whatever else it may be-must be promptly performed.

The "Tube Fumigator," which will be found to possess many advantages over the above, is useful

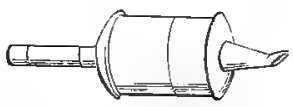
for several purposes. When a frame hive has to be disturbed it is requisite to raise the lid and blow a little 
smoke into the hive, so as to check the angry passions of the bees. If it be desirable to stupefy the bees, ignited fungus must be placed in the box and the flattened end applied to the entrance of the hive; the smoke is then blown in, either with bellows or by applying the mouth of the operator, taking care to close all openings through which it can escape. The bees fall down stupefied, generally in about ten minutes; but the effect varies according to the populousness of the hive and the quantity of comb in it. The projected operation must now be performed speedily, as activity will soon be regained. See preceding directions.

Another and quite a different means of subjugation has recently been introduced in the form of carbolic acid. The odour of this drug is so abominated by bees that the most refractory hive will be immediately subdued by sprinkling a few drops of it on the tops of the frames. But a feeling of humanity should suffice to prevent the trequent resort to so harsh a measure. We have in other places (Chap. V. §ii. and VI. § viii.) made allusion to the applications of the same fluid to the operation of transferring swarms and to the repelling of robber bees.

$\S$ XXII. BEE DRESS OR PROTECTOR.

All operations connected with the removal or the hiving of bees should be conducted with calmness 
and circumspection. Bees, although the busiest of creatures, entertain a great dislike to fussiness in their masters, and become irritable at once if the apiarian allows them to see that he is in a hurry. Hence there is great advantage in having the face and hands covered whilst at work amongst the bees; for when the operator knows he cannot possibly be stung, he can open his hives, take out the combs, gather in his swarms, or take the honey, with all the deliberation of a philosopher. Various kinds of bee dresses have been contrived; one that we keep ready in stock is of a very simple construction. It is made of strong black net, which is

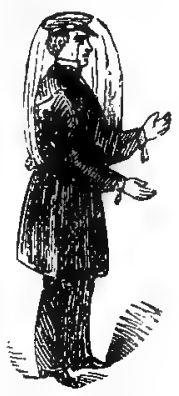
manufactured for us specially for this purpose, and in shape is like an inverted bag, large enough to allow of a gentleman's wideawake or a lady's hat being worn underneath. The.projection of the hat or cap causes the dress to stand off from the face, and the meshes of the net, though much too small for a bee to penetrate, are wide enough to allow of clear vision for the operator. An elastic band secures the dress round the waist; the sleeves also, made of durable black calico, are secured at the wrists by a similar method. The hands of the bee-master may be effectually protected with a pair of india-rubber gloves, which should be put on before the dress is fastened round the wrists. This kind of glove is regularly used by photographers, and allows of greater 
ease in manipulation than any other description. Some persons also tie strings round the ancles of their trousers, or use elastic bands for the same purpose. Those who wear Wellington boots will be able to tuck the trousers within them.

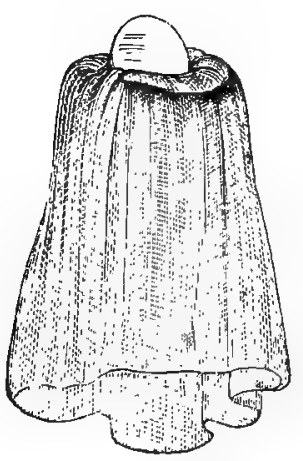

The annexed figure represents a cheaper form of bee veil which we have more recently introduced. It is provided with an elastic band which fits round the hat, the lower portion being folded under the coat. There is however no protection to the arms. It is made of the same specially constructed material as the preceding - a strong black net, with large meshes.

Thus a very simple and inexpensive means of protection will enable even a novice in bee-keeping to make his observations and conduct his experiments under a sense of perfect security. There are, of course, those who scorn all such artificial modes of protection, and having inured themselves to stinging take it as a thing of course, only to be restrained within some manner of limit by means of the persistent smoking of cigars or pipes (non-smokers such as Dzierzon use a sort of mouthfumigator). But it does not follow that none but these stoics are to be permitted to manipulate with bees, otherwise the number of beginners would be likely to be but 
few. And even he who is protected need not be careless as to the feelings of his bees; his success and their comfort will be promoted by his "handling them gently, and as if he loved them." "Familiarity" between bees and their master breeds not "contempt," but affection.* See further under "Stings" (Chap. VI. § vii.).

* Von berlepsch denies that bees come really to know their master so as to be able to distinguish him from any one else. We retain the remark in our text as true to the extent that they do become used to his manipulations.

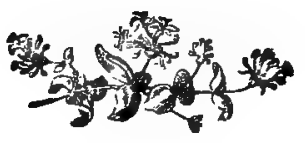




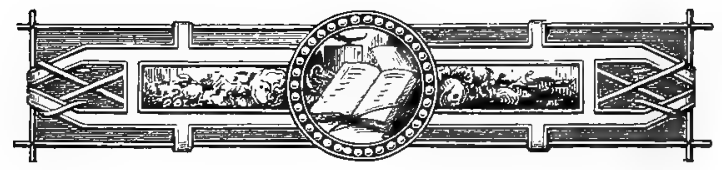

\section{CHAPTER V. \\ BEE MANIPULATION.}

\section{§. HIVING SIVARMS.}

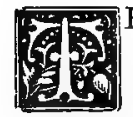

HE spring is the best period at which to commence an apiary, and swarming time is a good starting-point for the new bee-keeper. The period known as the swarming season is during the months of May and June. With a very forward stock, and in exceedingly fine weather, bees do occasionally swarm in April. The earlier the swarm the greater is its value. If bees swarm in July they seldom gather sufficient to sustain themselves through the winter, though by careful feeding they may easily be kept alive if hived early in the month.

The cause of a swarm leaving the stock hive, is that the population has grown too large for it. Swarming is a provision of Nature for remedying the inconvenience of overcrowding, and is the method whereby the bees seek for space in which to increase their stores. By putting on "super hives" the required relief may, in many cases, be given to them; but should the multiplication of stocks 
be desired, the bee-keeper will defer increasing the space until the swarm has issued forth.

In many country districts it is a time-honoured custom for the good folks of the village to commence on such occasions a terrible noise of tanging and ringing with frying-pan and key. This is done with the absurd notion that the bees are charmed with the clangorous din, and may by it be induced to settle as near as possible to the source of such sweet sounds. 'This is, however, quite a mistake: there are other and better means for the purpose. The practice of ringing was originally adopted for a different and far more sensible object-viz., for the purpose of giving notice that a swarm had issued forth, and that the owner was anxious to claim the right of following, even though it should alight on a neighboùr's premises. It would be curious to trace how this ancient ceremony has thus got corrupted from the original design.

In case the bees do not speedily after swarming manifest signs of settling, a few handfuls of sand or loose mould may be thrown up into the air so as to fall among the winged throng; they mistake this for rain, and then very quickly determine upon settling. Some persons squirt a little water from a garden engine with the same object. There are, indeed, many ingenious devices used by apiarians for decoying the swarms. IMr. Langstroth mentions a plan of stringing dead bees together, and tying a bunch of them on any shrub or low tree upon 
which it is desirable that they should alight; another plan is to hang some black woven material near the hive, so that the swarming bees may be led to suppose they see another colony, to which they will hasten to attach themselves. Swarms have a great affinity for each other when they are adrift in the air; but, of course, when the union has been effected, one of the rival queens. has to be disposed-of. A more ingenious device than any of the above is by means of a mirror to flash a reflection of the sun's rays amongst a swarm, which bewilders the bees and checks their flight. It is manifestly often desirable to use some of these endeavours to induce early settlement, and to prevent, if possible, the bees from clustering in high trees or under the eaves of houses, where it may be difficult to hive them.

Should prompt measures not be taken to hive the bees as soon as the cluster is well formed, there is danger that within one or two hours they may start on a second flight; and this is what the apiarian has so much to dread. If the bees set off a second time it is generally for a long flight, often for miles, so that in such a case it is usually impossible to follow them, and consequently a valuable colony may be irretrievably lost.

Too much care cannot be exercised to keep off the sun from a swarm when it has once settled. If exposed to. heat in this way, bees are very likely to decamp. We have frequently stretched matting or sheeting on poles so. as to intercept the glare, and thus render their temporary 
position cool and comfortable. For the same reason the hive used to take them in should not have been standing in the sun.

Two swarms sometimes depart at the same time, and join together; in such a case we recommend that they be treated as one, by putting them into a hive as before described, taking care to give abundant room and not to delay affording access to the super hive or glasses. They will settle their own notions of sovereignty by one queen being destroyed. There are means of separating two swarms, but the operation is a formidable one, and does not always repay even those most accustomed to such manipulation. If after one swarm has started there are signs of another setting out which might mix with it, means may be taken for securing the queen of the second, or sheets may be thrown over the hive.

With regard to preparations for taking a swarm, our advice to the bee-keeper must be the reverse of Mrs. Glass's notable injunction as to the cooking of a hare. Some time before you expect to take a swarm, be sure to have a suitable hive in which to take it, and also every other requisite properly ready. A bee veil or dress will preserve the most sensitive from the possibility of being stung. This article is fully described on page 209. But bees when swarming are in an eminently peaceful frame of mind; having dined sumptuously, they require to be strongly provoked before they will sting. Yet there may be one or two foolish bees who, having neglected to fill 
their honey-bags, are inclined to vent their ill-humour on the apiarian; or, what is far more likely, the bees of neighbouring hives may be incensed if they see him manifesting unusual excitement. When all is ready the new hive (a straw skep is the most convenient in the first instance, but if that is not at hand a box or anything else will serve as a substitute) is held or placed in an inverted position under the cluster of bees, which the operator detaches from their perch with one or two quick shakes; the floor-board is next placed on the hive, which is then slowly turned up on to its base, and it is well to leave it a short time in the same place, in order to allow of stragglers joining their companions. The operator should make sure that he has not left the queen behind on the branch, as in that case the bees would return to her.

Sometimes swarms alight on trunks of trees or on walls, where it may be difficult to shake or brush them off. The late Mr. Woodbury mentioned an instance of this kind. A swarm clustered among the large branches of a pear tree, just at their point of union with the trunk. In this case he merely supported a straw hive just over the swarm with the left hand, whilst he struck the trunk of the tree with the open paim of the right. The vibration thus produced sent the bees up into the hive with great rapidity, and the entire swarm was speedily hived in the most satisfactory manner. Mr. Langstroth in a similar case fastened a leafy branch above the bees with a gimlet, 
and then smoked them upwards till clustered upon it. It should be borne in mind that they have always a readier tendency to ascend than to descend. A feather dipped in carbolic acid will very promptly move them, and as they can readily escape from its fumes there is no objection in this case to its use. Another case of settling in an awkward spot is mentioned above (page 78 ).

If the new swarm is intended for transportation to a distance, it is as well for it to be left at the same spot until evening, provided the sun is shaded from it; but if the hive is meant to stand in or near the same garden, it is better to remove it within half an hour to its permanent position, because so eager are newly swarmed bees for pushing forward the work of furnishing their empty house that they sally forth at once in search of materials. If the removal has been made after they have gone forth they will be unable to find their home in its altered position, in which case they will circle about for hours till they fall and die from exhaustion. But by prompt transference, only the first despatch of scouts will be lost, and these are a good loss, as they might entice the whole colony to desert.

The bee-master should always seek to prevent his labourers from swarming more than once; his policy is rather to encourage the industrious gathering of honey, by keeping a sufficient supply of supers on the hives. Sometimes, however, he may err in putting on the supers too early or unduly late, and the bees will then swarm a 
second time, instead of making use of the storerooms thus provided. In such a case the clever apiarian, having spread the swarm on the ground, will select the queen, and cause the bees to go back to the hive from whence they came. But this operation requires an amount of apiarian skill which, though it may easily be attained, is greater than is usually possessed.

For a description of the theory and phenomena of swarming, with the signs by which its imminence may be gathered, and a variety of information referring chiefly to the habits and life of the insect, the reader is referred to an earlier article in this work (Chap. I. $\S$ xi.).

\section{§II. TRANSFERRING SWARMS.}

Where the permanent hive is of the skep description the swarm may of course be hived into it at once. But with many of the hives now in approved use a process of transference will be necessary. To effect this, place the straw hive, into which we will suppose the bees have been shaken, on the ground, propped up on one side with a brick or a flower-pot, or anything of the sort that may be handy, in order that straggler bees may join the swarm. The spot selected for this should be as shady a one as can be found, near to the place where the swarm settled; or it may be shaded from the rays of the sun by fixing matting on two poles, so as to prevent the heat falling on the hive. Spread a sheet or cloth on the ground where an even surface can be obtained; stake 
this sheet down at the four corners, to prevent ruts and inequalities, which are great hindrances to the bees going into the hive (Mr. Cheshire's swarming-board, which is simply a large square board to rest on the hive-stand, has its advantages); place the frame hive upon the sheet, without its floor-board, having its front raised on blocks or sticks rather more than an inch long-not more, otherwise the bees will cluster, and attach themselves to the lower part of the frames, instead of going up between. These preparations will perhaps occupy ten minutes, by which time the swarm will have become settled and tolerably quiet. Then, with a sharp rap, precipitate the bees out of the straw hive on to the sheet immediately in front of the frame hive; give the straw hive another knock, so as to dislodge all the bees, and then take it quite away, otherwise they may, if it be left near, perversely choose to go into that, instead of the one desired. In an hour or so, more or less, the whole swarm wilp have clustered within the frames.

In some cases, as when the swarm has to be brought from a distance and procured from a cottager about whose skill in carrying out these directions there may be misgivings, it is best to give instructions that the swarm be brought home after sunset, and then the foregoing directions for inducing the bees to tenant the frame hive may be better carried out. For ourselves, we much prefer the evening for the purpose. Not after dusk however -in fact no operation of the kind ought to be attempted. 
when it is so dark that the bees, if they should fly, are unable to see where to fly to, for in that case they will be sure to settle upon the operator. A little water sprinkled over them from a watering-pot is likely to induce them to quit the ground and go up into the hive more quickly; a little smoke, or a touch with a twig or feather, may answer the same purpose, and if the feather be dipped in diluted carbolic acid it will more speedily do its work. With a goose wing they may conveniently be swept up. The operator should be protected with the bee dress and other precautions described on page 209 .

Mr. Langstroth writes: "If they seem at all reluctant to enter [the new hive], gently scoop up a few of them with a large spoon and shake them close to its entrance. As they go in with fanning wings, they will raise a peculiar note, which communicates to their companions the joyful news that they have found a home; and in a short time the whole swarm will enter, without injury to a single bee." On catching the note the queen speedily follows, and, being longer in limb, she outstrips the others in the race.

In the Fournal of Horticulture, Mr. Woodbury says: "If combs be fixed in the frames, the crown-board may be removed and the cluster knocked out of the straw hive on to the top of the exposed frames. The bees will disappear between them with the utmost alacrity, delighted to have met with a ready-furnished dwelling, and the top, 
or crown-board, having been replaced, the hive should at once be removed to the position it is intended to permanently occupy."

Bees occasionally manifest a dislike to their new hive. The operator will, however, in a very short time be able to ascertain their intentions. If on putting his ear to the hive he-catches sounds like gnawing or rubbing, he may be sure that they have commenced work; but if all is still, or they go listlessly about, and hang, as Langstroth puts. it, "with a sort of dogged or supercilious air," it may be gathered that they intend to be off at the first opportunity. In such case, either catch the queen and put her in a cage (page 198), or keep the whole hive in darkness for three days, supplying food, water, and ventilation the while.

If the weather be wet the next day or so after hiving, it will be well to give a little assistance to the new colony in the shape of food, for although, when a swarm leaves a hive, almost every bee composing it has filled itself with honey, we have known not a few instances, in case of very wet weather, in which the whole swarm has been starved for the want of this small but most timely help. A little should be given the first night even in fine weather. Of course, the first work of the bees is to build themselves combs, and these combs being produced by the secretion of wax from honey, a great drain upon their resources immediately begins, and any little outlay at this juncture is therefore abundantly compensated. 


\section{§ III. TRANSFERRING OLD STOCIES.}

We frequently find that the possessor of a stock of bees in a cottager's common straw hive is desirous of removing the whole stock, with brood and comb, into one of our improved hives, in which the honey may be obtained without the destruction of the bees. We mostly discourage such a transfer, attended as it is with much labour, and requiring a considerable amount of apiarian skill. An old-fashioned hive may very readily be turned into a humane one, simply by cutting out the middle of the top of the hive with a sharp-pointed knife; a piece may thus easily be taken out, so as to leave a round hole two or three inches in diameter, taking care that the knife does not penetrate much below the straw, lest it reach the comb or the bees. There should be ready a round adapting-board, with a corresponding hole, which may be secured on the top by putting four long nails through the same number of holes in the board; then a cap-hive or a glass may be placed on the top, for the purpose of admitting the bees, who will soon crowd therein to work. This hive or glass will form a super or depriving-hive, and can be worked as profitably as most of the improved hives. For the sake of more sightly appearance, an outside case, either of zinc, straw, or wood, may now be dropped over all, and then, if well painted, the whole will form no disfigurement to any flower-garden.

This is, beyond doubt, the easiest way of overcoming 
the difficulty, but as it may not satisfy all, we will now proceed to describe how a complete transfer of colonies may be effected. No hive offers such facilities for the placing of the combs in a perfectly upright position as does the frame hive. As before remarked, we should be slow to recommend any one to attempt the operation who is not already pretty well accustomed to the handling of bees and acquainted with their habits; but by carefully carrying out the following directions an apt beekeeper may successfully perform the feat. The first thing is to get the bees away from the combs : there are two ways of doing this - one is by fumigation (see page 207), the other by driving (page 226). Whichever plan may be resorted to, place the bees in the temporary hive on their old stand until you are quite ready to admit them into the frame hive. Have in readiness all the necessary appliances. These consist of a large knife for cutting the hive, a good-sized table on which to lay the brood combs, a basin of water-for washing off honey which may besmear the hands - tape or string to fasten the combs in their frames, a pair of honey-cutters (page r93) for cutting out the combs, jars to hold the honey that runs out, and a feather for brushing off any bees that may remain. It is necessary that the operator should have on his bee dress and india-rubber gloves. If the old skep is not valued the operation will be facilitated by cutting it in half vertically. between the two middle combs; but the honey-cutters will accom- 
plish the object without this destruction if it is not desired. Mr. Cheshire's transferring board' (page I 92 ) comes in useful here. If one is possessed the frames may be laid upon it, and the combs, which should be cut as large as possible, must then be placed within these. -Of course they will not exactly fit, but they must be adjusted, piece by piece, till they bind each other together; the few interstices the bees will soon fill up. If in any of the frames there is not sufficient comb, supply empty comb if it is to hand, and in default of such, fix an additional bottom bar inside the frame-a false bottom as it may be called-at whatever height the supply of comb requires. Drone comb, however, should be used very sparingly, and this only for the outside frames, in which it is not likely to be selected by the queen for breeding purposes, but left for storage of honey. Both filled and partly filled frames must now be made secure by tying pieces of tape or pliable wire (even string will answer) round the whole from top bar to bottom or false bottom; there should be two of these to a frame, or perhaps three if the pieces of comb are small. In two days or so the bees will have made all firm enough for the tape to be dispensed with, which should accordingly be done, as it is in the bees' way. To effect this, dismember first the cells from the tape by means of a sharp knife, and then cut the tape and draw it out. Care should be taken that the combs occupy the same position in the frames as in the hive from which they were 
extracted, for the cells are not exactly horizontal, but inclined slightly upwards. Supply guide-comb or wax strips to any frames that are wholly unoccupied.

The frames now filled are placed in the hive, when the bees may be let into it in the manner Mr. Woodbury recommends for a swarm (see page 220). It may be as well to keep them confined a few hours, giving them water at the top, by means of a soaked sponge laid on perforated zinc, until they make the combs secure; the object of this being to exclude the bees from other hives, who, if feloniously inclined, might come to rob. For the same reason the operation of adjusting the combs should not be performed in the open air, or the bees from surrounding hives will be sure to come in great numbers to obtain a share of the honey necessarily exposed. It should be done inside a room with the temperature at about 70 degrees-not cold enough to chill the brood, nor yet hot enough to soften the combs. An expert apiarian could perform the operation in less than threequarters of an hour, and with little loss. A week or so after a swarm has left the old stock is perhaps the very best time for such a removal. In some instances a routing of this kind has a beneficial effect; old stocks of hives that have previously appeared to be dwindling are often aroused to activity by their removal into a fresh domicile. After the winter's doze this is especially the case, say if done on a warm day early in April. We have ourselves frequently shifted the stock from a well- 
occupied frame hive to a fresh one, in which the bees find a clean floor-board and walls, as well as freedom from insects that may have harboured in crevices during the winter.

\section{§IV. DRIVING.}

Driving is an operation by which bees are induced to vacate an old settled hive and to enter an empty one. Many apiarians prefer this mode of effecting an exchange of hives to the plan of fumigating the bees. The greatest success attending such a transfer will be in the case of hives well filled with combs that are worked nearly to the floor-board; and it may be remarked that bees are generally so far provident that they leave an open space in which to pass underneath their combs over all the floor of the hive. When the old hive is inverted the bees crawl up the combs, and thus more easily pass up into the new hive, which the operator places over the old one with the intent that they should enter it.

The best time for performing this operation is about the middle of the day, and when the weather is warm: It is essential that the operator be protected with a bee dress and gloves, as before described; and previous to commencing his task he must provide all necessary implements. These are - a couple of hives, both of which should correspond in shape and size with the hive from which the bees are to be driven; a cloth to tie round at the juncture when the new hive is placed on the old one; 
some string to keep the cloth in its place; an empty pail to receive the top of the old hive, if one of the old conical shape, but if the stock of bees is in a square box- . hive with a flat top, a firm stool will be the best; and a tube fumigator with some fungus, which will complete the material of war. The bucket or stool must be placed securely on the ground, about a yard from the place where the full hive stands; then a few puffs of smoke, blown in amongst the bees, will cause them to retreat up amongst the combs. The bee-master must now turn the hive * upside down very gently, letting it rest in the pail or on the stool; he then quickly places the empty hive over the full one, and ties the cloth round it, to prevent any escape of the bees. If the cloth be damped it will cling the closer to the hives. The third hive, which should resemble the old one even in colour, is intended to be placed on the stand formerly occupied by the stock, so as to retain the few returning bees which had been absent in the fields. Care must be taken that all crevices through which it is possible for the bees to escape from the united hives should be effectually closed. When the two are fairly united, the operator will proceed by rapping the full hive gently with the hands or a couple of sticks, more particularly on that side where the combs are the most thickly placed--that is, if the hive be not

* Care should be exercised in turning the hive over to keep the combs vertical by turning it in the direction in which they hang, and not crossways, or they are likely to break from their foundations. 
equally filled on all sides. A stock is in the best condition for driving twenty-one days, or thereabouts, after a. first swarm has issued; the brood will then have hatched out, the bees will quit more readily, and there will be no loss of larvæ in the cells.

It generally happens that in ten or fifteen minutes the bees regularly commence the ascent; their exodus will be known by the distinct rushing sound which is always noticed when a colony of bees is on the move. The first thing bees do when disturbed is to fill their honeybags, as they invariably do at swarming time; consequently, after the first rush into the new hive is over, as in the case of a swarm, the "flitting" bees are not much disposed to take wing. When the noise made by the ascending bees has been heard, and has in a great degree subsided, the cloth may be removed, and the old hive, now deserted, may be taken indoors; and if a few bees yet remain they may be brushed off with a feather. An experienced apiarian, on first hearing the rushing noise before mentioned, will not hesitate to tilt the top hive over a little on one side, so that he may watch the bees during the ascent; the queen may be seen passing up, and if the operator desires to take her away he can secure her by gently taking her between thumb and finger. Those who have become experienced in this operation find that it can safely be performed with the hives fixed open from the first. This is called "open driving," and can be effected with increased facility by sticking two skewers 
through the rim of the lower hive in such manner that they shall act as props to keep the upper in a fixed position. Mr. Hunter has, however, devised an improvement upon this, consisting in a wire hinge to connect the two hives, and wire rods to prop them open. The operator thus has both his hands at liberty for other parts of the work.

If the taking of the honey be the object of the beemaster, then "driving" is manifestly a' better plan than resorting to the fumes of sulphur for the purpose; for the bees from whom the store is taken can be joined to stocks that are weak in numbers, with considerable advantage to the future prosperity of the apiary (see next section).

\section{\$ V. UNITING COLONIES.}

A weak colony may frequently with advantage be added to another, or three may be made into two. And not only may this be done with new swarms, but in autumn, when there is no brood in the combs, it may be carried out also with stocks, the combs that are extracted being taken care of for use when required. After working hours is the best time for this operation. It is not, however, altogether a simple one, as strange bees will not intermix unless measures are taken to overcome their natural hostility to each other. Whatever be the number of hives in an apiary, the bees of each know the smell of their own companions. A single bee that enters the 
wrong hive will be stung to death, unless possessed of a good booty wherewith to disarm animosity. Similarly on the admixture of entire colonies, if one has some distinct ground of advantage over the other, there must be a method hit upon to deprive it of this or else to purchase its goodwill, for otherwise there will ensue a ferocious and disastrous slaughter. If both are alike frightened all will go well, and the same if both are upon the wing in search of a home; but quite otherwise if one is self-possessed and active in its own abode, while the others are frightened strangers and gorged, and it may be still further demoralised by having lived under an unfertile queen, or with none at all. But if both are cowed alike by a good drumming on the hives, they may be sprinkled so as to possess the same scent, and then taken to a third position and shaken out on to a sheet together, when they will enter the offered hive in harmony. If each colony has a queen, one of them may be searched for and removed.

A slight variation upon this method consists in driving the bees of the one hive (see last section) straightway into the other, having first terrified the bees of the latter by drumming until by their changed note they may be concluded to be thoroughly subdued, and as a consequence gorged with honey; then, before their equanimity is recovered, the others must be joined to them. A third plan is the one usually practised with the Stewarton hive (page I5I), and which can be imitated with other hives, 
by means of ekes or nadirs; this is usually carried out in the evening, when the quietude appears efficacious in settling all differences without the necessity of any other precautions. A fourth is as follows: At dusk, dislodge the bees on to a cloth, sprinkle them with sweet syrup scented with essence of peppermint (as a means of bribing their new hosts to receive them), and place the hive to which it is intended to join them over the mass; they will gradually ascend into the hive placed for them, and early next morning the hive, with its slender stock thus augmented, may be removed to its stand. Should the operator not have been successful in gaining possession of the queen, he may leave it to the bees themselves to decide which queen they will have.

Many persons feel more secure from stinging if they first stupefy the bees by fumigation. These should proceed as follows: Having used the fumigator upon the bees in one hive, as described under that article (page 207), place a sheet on the ground and spread the bees on it; then, with a feather, sort them over, in order to pick out the queen. As soon as she is found, pour the rest of the lethargic swarm from off the sheet back into the inverted hive again. The stupefied bees must now be sprinkled freely with a syrup made of honey and water, or sugar and ale boiled together. Some apiarians recommend a few drops of peppermint to be mixed with the syrup, in order to drown the peculiar odour which is special to each hive of bees; this is more necessary when 
both hives are fumigated, and whilst under the influence of smoke are well mixed together upon the sheet or board. Such course can be adopted if preferred, and no further instructions will be needed than what are here given; but we will suppose as before that only one is thus operated upon. The hive containing the non-stupefied bees must now be placed on the top of the inverted one, just as the hive was from which the bees in the latter have come. A wet cloth must be fastened round the two hives, so as to prevent any of the bees from escaping. The hives in this position must be placed where they are not likely to be knocked down or meddled with. The fresh bees in the upper hive, attracted by the scent of the bees besmeared with honey, go down and commence licking off the sweets from the sleepy ones. The latter gradually revive, when all get mingled together and ascend in company to the upper hive, where they live as if they had not been seprarate families. The two hives should be left undisturbed for twenty-four hours, when the upper hive may be removed and placed immediately on the spot from whence it was brought.

The removed queen should be kept alive and fed as long as she will live, in case any harm should befall the sovereign of the other community. If three hives are to be incorporated in two, the only difference will be that the stupefied colony upon the sheet is divided into tzero empty skeps, the one being covered securely over till the other is adjusted. 


\section{\$VI. ARTIFICIAL SWARMING.}

Every bee-keeper knows the anxiety he feels in watcking and expecting a swarm to come forth, fearful lest his favourites should, "like riches, take wing and fly away "--a mischance that it is desirable to prevent. In our description of natural swarming this will be found fully treated of; we propose here merely to point out how, especially with movable frames, this work of Nature may be assisted. We call it assisted, because artificial swarming should, as nearly as possible, resemble natural swarming; that is, it should be performed at the same time of the year, and when the populous state of the hive makes a division desirable. This is easily known to be the case when bees hang out in clusters at the entrance, wasting their time in enforced idleness instead of being abroad gathering honey. It is also necessary that there should be drones about at the date chosen.

When such is the state of the hive, the advantages of movable-frame hives are strikingly manifested. With the others the bees will often persist in wasting their time as just stated when a swarm would put all to rights ; while they are often just as awkward the other way and will send out swarm after swarm which the strength of the hive cannot spare and which in themselves are unable to form colonies capable of self-support and of repelling robber bees. The great expenditure of time and labour by the bee-keeper, with the fear that after all the swarm 
may come off at a time when he is absent, and thus be perhaps lost, are additional objections to depending upon the natural process. An apiarian may if he pleases give the bees their chance, and then if they do not swarm readily he may resort to artificial means. But if he wishes to dispense with the former altogether he will have to adopt measures of prevention against it, as his forced colony must not be procured till the proper time of natural swarming. Some clip the wings of the queen, which seems a clumsy proceeding at the best-though recommended by high authorities from Virgil to Langstroth -as the royal mother may still wander forth and thus fall to the ground and be lost. Others block the entrance of the hive with some obstruction which only workers can pass, by which means the drones will also be kept at home. If this be the method pursued care must be taken that the obstructions are removed both after sunset and before sunrise to permit of the dragging out of the bodies of such as have fallen among the hourly victims of the gathering season.

The best time for performing the operation is about. ten o'clock in the morning of a fine summer's day. The following directions should be carried out: Place ready a counter or bench that is firm and strong, and which has space on it for the inhabited-or, rather, the overinhabited-frame hive, and the empty one, which is about to be made the receptacle of a separate stock. The operator, attired in his bee dress, and having the other 
appliances reàdy, may now open the hive* (as described at page $\mathbf{2 7 0}$ ), and proceed to take out the frames, carefully examining both sides of each comb to find the queen : $\uparrow$ she is generally in the centre of the hive, so that it is not always needful to take out every one of the frames. As these are examined they may be put into the empty hive, and when the object of the bee-master's search is found he must carefully remove the frame containing her majesty, and may place it temporarily in the empty hive, at one end by itself, or he may make use of the barframe holder (Chap. IV. $\S x$ i.). Next he must proceed to put the frames back into the old hive, closing up the vacancy caused by the removal of the comb with the queen on it, and leave the empty frame at the end: Then he may place the frame containing the queen, with the few bees that may be upon it, in the centre of the empty hive; and, finally, putting all the other empty frames in, and replacing the lid, he will place this hive in the exact position occupied by the old stock. The bees that are on the wing will go to the old spot, and,

- Bees are apt to take the interference more quietly if the stock is moved a little distance from its accustomed stand; in such case, put an empty hive in its place, to amuse returning bees. These can be shaken out when the hive it is desired they should inhabit is restored. If this is kept in a closed bee-house the entrance should be shut down until the hive is replaced, when the clustered bees may be at once admitted.

† Italian queens are more easily detected, being of a brighter colour, and, generally, larger than English queens. 
finding the queen there, they will rally round her, and if a time is chosen when a large number are abroad, they will on their return very soon form a sufficient number to constitute a swarm; comb-building will at once begin, the frames will, in a week or so, be filled, and a satisfactory stock will thus be established.

This operation we once performed - exactly as described above except that there was no frame-extracting-with one of our improved cottage hives. Whilst inspecting our bees we caught sight of the queen on the comb in one of the bell glasses. This was a chance not to be missed, and we immediately resolved to form an artificial swarm, for the hive was very full of bees. Besides, being obliged to be away from the apiary most of the week, we were glad of the opportunity of so easily establishing a colony without the uncertainty and trouble of hiving a natural swarm. In the first place we slid a tin under the bell glass, and, removing the stock hive from underneath, we took it a few feet away; then we placed an empty improved cottage hive where the old stock had stood, and put the glass of comb containing the queen and a few bees over one of the holes in the crown of this new empty hive. The bees that were left abroad belonging to the old stock returned as usual to their old entrance as they supposed; soon a sufficient number formed a large cluster in the hive and began combbuilding, the queen remaining in the glass until the cells below were sufficiently numerous for her to deposit her 
eggs in them. 'Ihe experiment answered exceedingly well. Both hives prospered: the old hive either had. some princesses coming forward to supply the loss of the queen, or the bees used the power that they possess of raising a queen from worker brood in the manner we have previously described (page 16 ).

The foregoing account illustrates the successful formation of an artificial swarm; but, with a cottage hive, gaining possession of the queen is on this method quite a matter of chance. With a movable-frame hive she can at any suitable time be found.

Precisely the same plan is to be adopted with the old stock in the frame hive as we have described in the case of the cottage, that is, to remove it some few paces off: when the hives are in a bee-house a similar result may be obtained by placing the new swarm for a day or two so as to be reached by the same entrance as the old stock, and the latter may be removed to one close by. Some apiarians recommend that a space be left between the two hives, by arranging them on the right and left of the old entrance, in order that too large a proportion of bees should not enter the new hive at the old position, to the impoverishment of the other. But we have found the mode adopted with the cottage hive answer so well that we see no reason for recommending any different plan.

It is the office of the bee-master to assist, not in the least degree to oppose, Nature. We know that when a 
natural swarm issués forth it has its queen, and when located in a new abode it commences building worker combs, leaving the building of the few requisite drone combs to a later period. But if a division of the hive should be made, by putting half the combs in one hive and half in another, the hive that is either queenless or contains an embryo queen will busy itself with building only drone comb (see page I 7 ); thus a number of receptacles for useless bees are provided, while all the time the colony is rapidly dying off from the wear-and-tear of the working season.

In the plan we have recommended for forming two separate families we nearly follow the natural course of things; the comb that the queen is upon is the only one that is taken from the hive, and this vacancy should be filled in by moving the frames together, so as to leave the empty frame at the end. The swarm under the government of the queen construct the combs, and furnish their new abode, as before stated, with worker cells. By adopting the plan above described, the movable-frame hive will prove far superior to any of the dividing-hives, which provide for equal division of the combs.

There are, however, quite a host of other modes of procedure more or less varied from the above, and their number is doubtless capable of almost unlimited extension. Mr. Langstroth, in the tenth chapter of his "Honey Bee," describes a considerable variety of them, nearly all of which are accomplished wholly or in part by the 
process of driving. The following he particularly "recommends as approaching nearest of any to natural swarming. Two hives exactly alike are placed one above the other with their entrances different ways; they have holes made through their floor-boards to allow of communication from the crown-board of whichever for the time occupies the lower position. Free passage being thus given from one to the other, a number of the young bees will use the upper entrance. After some ten days a swarm is driven from the lower and received into the upper, upon which the positions of the hives are reversed, the forced swarm being put below. Most of the mature bees will unite with the swarm from association with the lower entrance; but the young ones which have habituated themselves to the upper one will now cling to the parent stock and form a sufficient strength to keep it properly going. In the course of a few days the upper hive may be placed by the side of the lower, and then, by successive short steps, removed to any other part of the apiary. If it was found that either hive was too weak the positions should be again reversed.

When driving is the method resorted to, it becomes absolutely essential, in forcing a swarm, that the queen should go with the new colony; but on the other hand it is not in this case the object to drive all the bees from the parent stock, but to leave, say, a quarter to preserve warmth for the brood and to raise a new queen. If therefore the queen is not observed in the 
ascent of the bees after the drumming, those in the swarm must be turned and shaken over in the skep in order to find her (they will not attempt to fly, but only crawl). An inexperienced eye may still fail to detect her, and in that case it will be best to set both hives upon stands for a short time-the new one on the old stand and the old on some other-when within half an hour the one which is fairly quiet may be judged to be possessed o the royal presence. Should this be the old hive it must be again drummed, or the swarm may be returned to it and the operation renewed on a following day. It is, however, only with skep hives that any difficulty of this kind need be apprehended-there is always the power of capturing and transferring the queen from movable frames. When at last she is in the desired hive the swarm is secured, and the after measures depend on the number of bees that have accompanied her. If the stock retains one-half it may be moved to a new position and the swarm take its place upon the old stand. Whichever occupies this latter post will detach largely from the strength of the other, so that the reduction undergone by the parent stock will not be more than it will probably be able to sustain.

As detailed in the above article on "Driving " (page 226), there is a third hive made use of in this case, which has received the bees that returned home during the operation, and these are now added to whichever hive may most require them. Should too many have gone 
over with the swarm, this latter may be taken away and set in a cool airy place, while the old hive is carefully restored to its old stand, when the bees which were distractedly flitting in and out of the third hive will at once rush into it, and the impression made upon them by the occurrence will be such that they will now cling to it wherever it is placed. It must be forthwith removed to its intended permanent position, but if still short of bees this must be close at hand, so that if the forced swarm is kept where it is for a day or two a good number may desert to the old stock; its entrance should be closed until sunset as a precaution against robbers, but not. so as to stop ventilation. The forced swarm, if not in their permanent hive, must now be treated as an ordinary transfer, and their fixed abode be brought in the evening to the old stand. Some additional covering may be needed at first, and in very cool weather the operation should not be attempted at all. There is no fear of all the bees deserting in the arrangement just suggested, and if inconvenient to complete the operation at once the swarm may be so left, even if there appears no need on account of the old stock.

The process of driving is the only method of obtaining artificial swarms from cottage hives, except in such rare cases of good fortune as the one mentioned on page 236 ; but even with frame hives it is often practised for the sake of its rapidity. But with an experienced operator the same result can be achieved by simply taking 
out the frames one by one and jerking off the bees on to the sheet in front of the new permanent hive; that on which the queen is found will be inserted therein just as it is-queen, brood, and workers. If the swarm is being collected in a skep the queen must be taken with the fingers and deposited therein, while the bees from as many frames as are needful must be shaken in after her.

There is sometimes a doubt whether a hive is strong enough to yield a swarm, though apparently overstocked. In such cases there is an excellent plan, devised by $\mathrm{Mr}$. Langstroth and strongly approved by Mr. Cheshire, for obtaining a single swarm out of two hives. On a suitable morning, when large numbers are upon the wing, drum a strong stock till every bee has left it. Place the forced swarm on the old stand : this of course consists of bees in an unfurnished hive, while the old hive has lost all its bees, but retains its brood. Remove this hive to the stand of another strong stock, the hive of which goes to a third spot with the bees inside it at the time. Those of this last which were upon the wing will enter and remain with the first hive and raise a new queen; while sufficient will be transferred with the second stock hive to protect its brood also. Thus the first stock gives no bees to the swarm, but the whole of its brood; the second gives the larger half of its bees. If frame hives are the ones used, the shaking process of the last paragraph may be substituted for drumming; but as it may not be possible to shake off every bee without damaging the combs, a 
goose wing should be employed to brush off the more tenacious of the occupants.

Other modifications consist in either obtaining one swarm out of four or five hives, or else one less than their own number out of the same. For the former (frame hives) two combs may be taken from each and placed in a new hive, which is then set upon the stand of some strong stock. For the latter, a swarm is forced, after or before working hours, from each of these hives, while another swarm, that has been procured from some beekeeper a mile or two off, and has been kept in a cool place, is now shaken on to a sheet, sprinkled to keep it from taking wing, and softly scooped up with a saucer and divided equally or as required among the hives that have yielded the swarms. The distance that these bees have come will prevent them from returning to their own home.

\section{§ VII. QUEEN-REARING.}

Perhaps the greatest advantage the movable-frame hive possesses is, that a full knowledge. can be attained of its exact state as regards the queen, the population, and the quantity of food in stock. During weather of a genial temperature the combs may on any fine-day be inspected, and thus, a knowledge being gained of the deficiency existing in a hive, the necessary means may be adopted for supplying the want. Sometimes such an examination will verify the fears of the bee-keeper, 
when, having observed that his bees have ceased to carry in pollen, he has thereby received warning that the queen has been lost at some juncture when no successor to the throne could be provided. Such a hive has entered on a downward course and will dwindle away entirely, unless a queen should be given to it, or else some combs containing young brood not many days old (see page 16). By the latter method the bee-keeper will gain an opportunity of seeing the bees set about their wonderful process of raising a queen from the brood thus provided for them. If neither means is practicable the colony must be united to some other hive.

An ingenious little contrivance has been brought into use by continental bee-keepers, especially by Herr

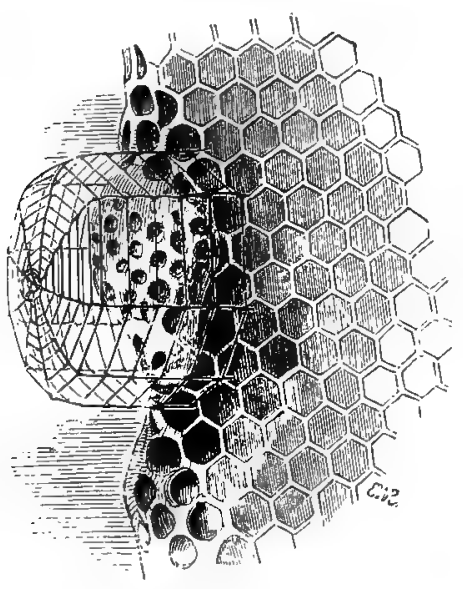
Kleine, a German pastor, to prevent the destruction alluded to. It consists of a small wire cage (in fact, a pipe cover), as represented in the annexed illustration, placed over a queen cell to protect it from the mother bee's animosity. It also serves to prevent the young queen, when hatched, 
from escaping; for she will have the same jealous feeling towards her sister princesses, should there be more in the hive. The bee-master may thus carefully remove and appropriate her.

Particular attention will have to be exercised to affix the cage into the comb by pressure, as far as the middle wall, but at no point must it touch the royal cell itself. As the cage will probably project so as to touch the adjoining comb, a little incision and removal of a portion may be necessary to allow space for it.

This covering need not be put over the cell until the egg is a little more than a week old. The animosity of the reigning queen does not generally manifest itself until the royal brood approaches maturity. These cells are unmolested on the tenth day, but on the eleventh day they may be found tenantless. Notwithstanding the apiarian's care and skill, many disappointments are frequently experienced in endeavouring to establish. fertile young queens at the head of colonies.

Hives found to be queenless may be supplied either with matured queens or with queen cells. If the latter are sufficiently numerous, their introduction may easily be effected by exchanging a comb in each hive; if they have to be cut out and placed loosely in the new hive, a triangular piece of comb should then be removed with them, to be used as a block in preventing any pressure coming on them. A space must be cut out of the middle in the centre combs of the hive into which they 
are to be introduced. They must not be so loose as to be in danger of falling out, but if such seems likely a little melted wax should be applied with a feather. Special care must be exercised not to bruise the royal embryos, as a very slight pressure is likely to be fatal. It is important not to perform the operation till they are within three or four days of coming forth, which may be known to be the case from the brown look of the tops of the cells, the wax having been removed.

It is always easier to introduce royal brood into queenless hives than matured queens, because bees are reluctant to receive stranger queens, whilst they will tolerate one hatched in the hive, who will speedily depart to seek a drone. Bee-masters mostly use small hives for queenrearing, as explained in the section on "Nucleus Hives" (page I 97). It is not however indispensable to use other than the ordinary hives, and Mr. Langstroth gives the following as the very best mode of procedure. Place an empty hive on the top of a well-filled one, giving communication through crown and floor boards and turning their entrances opposite ways (one of his plans, by the bye, for procuring an artificial swarm). The young bees will many of them take to the upper hive-if not they must be enticed into it by food-and when there are sufficient of them, a brood comb with adhering bees must be inserted and the connection closed. After a few days this nucleus hive may be removed, a few steps at a time, and another, if desired, take its place and be raised in 
the same way. Queen-rearing operations must be confined to warm weather and when drones are abundant.

Royal cells are often built so close together that it is difficult to remove one without injuring another. As a remedy for this Dr. Dzierzon has made the important discovery that any convenient worker cell may be made to produce a queen by the removal to it of some of the royal jelly from an unsealed cell; by placing this on the inner margin of the cell selected, the bees will adopt and rear the larva as desired.

\section{§ VIII. INTRODUCING NEW QUEENS.}

This is an operation that is continually being practised for the purpose of Italianising a colony, though there are other occasions for its adoption, as on the loss or the superannuation of the old queen. We will in the first place describe the mode of procedure with a frame hive.

Should the old queen be remaining in the hive, she has first to be removed. Having discovered her, by lifting out and examining the frames (see page $27 \mathrm{I}$ ), place a wineglass over her whilst on the comb, and, with a card passed very carefully underneath, she may, with a few of her subjects, be made a prisoner and easily removed. She should be preserved in a small box till the success of the new introduction is ascertained. Then, having enclosed the new queen, with such of her retinue if any as are with her, in the domed wire cage described at page 199 , place this cage upon the comb in a spot where 
there is a little honey, so that she may be independent of the bees for food, and as near the brood as may be; press it into the comb as far as the middle, and close the hive and leave the bees undisturbed for three days-less will mostly suffice, but it is best to be on the safe side. The royal cells that are sure to have been commenced should now be cut away with a penknife, and then the new queen may be carefully released. If the hive is one that permits it, her reception should be watched. If the bees make way for her and caress her with their antennæ, all will be well, and the comb may be gently restored to its position and the hive shut up. But if they cluster in a ball around her, her death is intended; and if they cannot readily be induced to separate they should be taken out and dropped into lukewarm water (which will hurt none of them), and the queen reencaged for another day or so-that is, if she has not already met her doom, which is all uncertain: $\mathrm{Mr}$. Langstroth says he has had several queens stung to death before they had quitted his fingers! We prefer effecting her release, then shutting up the hive and leaving the bees quietly to themselves.

We may remark here with regard to these acts of surrounding a new queen, that they evidently arise from a great number rushing upon her at once for the purpose of stinging her, but that very frequently such purpose is frustrated by the immovable position in which the inner bees are held. Suffocation however will soon effect the 
same end if the ball be not dispersed. There are cases, on the contrary, in which friendly bees surround a queen to protect her from others, and sometimes the knot is made up of members of both parties, perhaps without enclosing the queen at all. The hissing note will at once distinguish a hostile onset from a protecting rally.

With the Renfrewshire cage (page 199 as above) all the variation needed is to place the cage between instead of within the combs, so as to permit of the queen's release at the bottom. The inventor considers that this gives an advantage in introducing her majesty in the first place to those bees that have been engaged in feeding her; but, as alrendy noticed, it is not the feeding, but the familiarising with her presence, which is the great point, and that is surely quite as well accomplished with the other cage as this. There is also here no opportunity, as in the other case, of being certain whether she is well received or not, so that we always put a good-sized board under the entrance, and examine the next day whether she has been thrown out dead or not.

In effecting the exchange with cottage hives, the bees must first be driven out into another hive (as described at page 226), and after the old queen is removed they must be sprinkled with a little water flavoured with a drop of extract of peppermint (to be obtained of any chemist), which overcomes the particular hive-scent, and makes all smell alike; then throw the new queen in among them and place the mass of them back in the hive. If 
preferred, an eke (page I 86) may be placed on the stand, the bees precipitated into it, and the hive of combs placed above, when the bees will ascend. If this is done in the evening the queen will in most cases be well received. As there is no opportunity of excising queen cells, the process should be performed, say, in the middle of October, when breeding has ceased. Stupefying the bees with fungus is a method devised by Hüber as applicable in any kind of hive, and it has been highly approved of and declared to be infallible.

A strange queen is generally well received by young bees, whether she be Italian or English-for we have never found the slightest difference in reception, though Mr. Wagner (Langstroth's "Honey Bee," page 325) was of opinion that there is more opposition in the case of the foreigner. The difficulty is to have a sufficient number of such young bees. In the middle of a hot summer's day a stock may be divided and the part with the old queen left in its former position, while the other part, with as many brood combs as it is prudent to take, may be removed a few yards off. The old bees that have been brought with the latter will in three or four hours have most of them returned to their former abode, and the new queen may then with safety be given to the remainder without caging, taking care to introduce her to the young bees on the combs. This task must only be attempted on a warm midsummer day and when the night temperature need not be feared for the young 
brood in its deserted condition. Stocks may be divided and artificial swarms formed in this way-from the end of May to the beginning of July-if the apiarian.has queens in readiness.

\section{§ IX. ITALIANISING.}

It requires a considerable amount of apiarian skill to accomplish the union of Italian with common bees, so that we find by experience it is best to send out complete stocks or swarms of the former. This is particularly desirable now that the packing of whole hives is so easily accomplished by us with the aid of bars and frames. We have sent a great number of stocks to all parts by rail. Still, as the introduction of fertile Italian queens is a frequent practice, and we are ourselves large importers of the same, it is only right to add some directions as to the course to be pursued where such union is resolved upon. These queens come over during the summer months, from May to October. They are packed in wooden boxes about five inches square, with a comb of sealed honey in a frame in the centre to feed the queen and the few workers that accompany her on the journey. The old queen should first be removed from the hive, but carefully preserved till it is ascertained whether all goes well with the stranger. The box containing the latter must now be prised open, and this should be done within doors, lest the queen should fly and be lost. On discovering her she must be placed in a queenn-cage and 
gradually introduced to her new subjects in the manner explained under that article (pages 198 and 247).

If this is successfully accomplished all is right so far; but unless considerable pains be taken the off-coming swarms will certainly produce mongrel bees. If none of the neighbouring residents are bee-keepers, the risk may be considerably narrowed by destroying the drones and drone comb in the other hives and rearing Italian queens to place at the head of each of these as speedily as possible. Every one of these queens, even if impregnated from an undesired source, will still produce drones as purely Italian as herself (see page 64 ), and thus in another year the chance of Italian mates being found for the queens will be further increased : indeed the peculiarity of Italian queens in laying drone eggs in their first year will probably produce this result more speedily. But should some hybrids be the result, as in all probability will be the case, even these are much to be preferred to the common black bee-some say (see page 53) that they are even better than pure Italians for honey-gathering, but they are more irascible.

This course is undoubtedly in opposition to the design of Nature to avoid interbreeding, but we find even Mr. Hunter recommending it, though showing in another place that he perceives it to be a violation of his "law." By commencing with truo Italian queens there might be more chance given of escape from the evil-if it really is an evil when not sereral times repeated. Von Berlepsch, 
however, informs us of the following method, devised by Dathe and others, by which even this objection may be avoided :-

"When the young queen has left the cell, she is transferred after forty-eight hours, or even earlier, into a cellar or some other dark and cool place. If the drones, by one of which the impregnation is to be accomplished, are not among the colony of the queen, they also must of course be inserted. We now wait for a sunny day free from wind, when the thermometer in the shade is at least $17^{\circ}$ above zero $\left[70^{\circ} \mathrm{Fahr}\right.$. ; the bees in question, towards five in the afternoon, when drones have completely ceased from flight, are fetched out of their prison, and set up in any spot, if possible where isolated and with the flighthole exposed to the sun; then, by means of a small syringe or in any other way, direct some liquid honey into the flight-hole. In a minute or two the bees will sport in numbers in the front, and sit will not be long before the queen and drones also fly out. At evening the colony is brought back into custody, and the manœuvre is repeated till the young queen has commenced laying, or till her accomplished fructification is made sure by expansion of the abdomen, or, upon return from a flight, by having the more or less torn-off drone penis upon her extremity." Some essential particulars are not here specified, but we interpret the instructions to refer to a nucleus hive in which the queen is hatched with several workers, "but with no drones present except those 
specially introduced. By choosing these, also from their birth, from the progeny of a different queen from the mother of the one in the nucleus, all may apparently be made as straightforward as could be desired. Even Von Berlepsch, who is no friend to the Italians, praises this method as a "beautiful discovery:" it dates only from 1867 .

\section{$\S \mathrm{X}$. GENERAL HINTS ON FRAME HIVES.}

It may not unnaturally be asked by some, Why all this trouble about frame hives? No one, however, who has carefully read the previous sections of this chapter, and especially those on "Artificial Swarming" and "QueenRearing," can require any further answer to such question. Briefly, frame hives stand immeasurably above others from the full command over the bees which they afford. The facility of inspection for ascertaining the strength of the colony or the stock of its honey, or for incidental purposes, such as the detection of disease and the extirpation of enemies such as the bee-moth, and again the facilities provided for giving ventilation or for contracting the dimensions to suit a small population, are among the minor but still great advantages which the use of these hives secures. In skilful hands these advantages may be used successfully; though in the hands of the unpractised and unskilful the contrary may be the result.

It is a great desideratum that all the bars and frames in an apiary should be of precisely the säme dimensions, 
so as to fit every hive. A hive that is weakly may often be advantageously strengthened by having put into it a comb of brood from a populous stock, to which an empty frame from the weak one may be given; no bees must be on the brood-comb-these should be shaken off or gently dislodged with a feather into the hive from which the comb is taken. The frames of combs should then be, one by one, placed so as to fill in the vacancy, leaving. the empty frame nearest the side.

In the British Bee Foumal of March 1875, Mr. Cowan gives the following excellent description of his system of working frame hives. He says: "The method is very simple, but is one that requires much attention, which is, however, well repaid by the extra quantity of honey obtained. The hives I use are the ten-frame Woodbury, and thirteen-frame on the Woodbury plan, only longer. In the autumn I transfer the bees into clean hives and leave them seven or eight frames, and should they be short of food or of bees I add those I may take from the cottagers in the neighbourhood. I feed with sugar and water of the strength of two pounds of sugar to a pint of water boiled a few minutes. They are fed up to a weight of thirty pounds. During winter they have ample ventilation - the hives being raised about one-eighth of an inch from the floor-board, and the top board is also raised about the same height, so that there is a constant current of air through the hive. While I am on the subject of wintering I may mention that I 
have tried several plans. With the above I have always been free from mouldy combs. I have also tried wintering without crown-boards, by merely placing an empty super on the top, and I have done so successfully-in fact, the hive which produced the largest quantity of honey last year was wintered in this way. Condensers I have tried, but give the preference to crown-boards without them. I am trying the quilts on some of my hives, but must reserve my opinion about them until later on.

"I generally supply my bees with plenty of food in the autumn, so that they require no further attention until about the end of February, when, if the weather is fine, the bees are all thoroughly roused into activity and induced to commence and continue breeding until the honey-gathering season commences, by which time every frame in the hive is filled with brood, and the hives are so strong that it is easy to make an artificial swarm and to ensure a good supply of honey besides. If the weather is fine, about the end of February (or if cold, then I defer a little longer) the bees are transferred into clean hives; and in this way I get to know the exact state of the community. Now suppose it is a ten-frame Woodbury hive. I do not return the whole of the eight frames which the bees had for wintering on, but only from five to six of the centre ones, and contract the size of the hive to the six frames. I then unseal the honey-cells of two of the frames, and allow the honey to run down inside the hive. This thoroughly rouses the bees; and 
the queen at once begins to lay. The running honey is very soon collected and stored; and in a few days I do the same with a couple more frames, and so on until all the frames have been unsealed. I find this a great advantage, as much of the honey that has granulated, and which the bees will not touch, is removed by them out of the hive, and gives them increased space.

"I now commence very gentle feeding, for which purpose I use the very fine strainers found in Loysell's coffeepercolators, and allow each hive from a quarter to half a pint of food a day, of the strength of about three pounds of sugar to a quart of water. When there is sealed brood in three or four of the frames I add two more-making eight-and serve them in the same manner as the rest; then when there are six with sealed brood, the colony will be sufficiently strong to have the remaining frames added. The same plan is adopted with the thirteenframe hive. They must be constantly watched so as not to allow them to store too much food, which would diminish the space for egg-laying; and if such is found to be the case, food should be withheld for a day or two, or until they are getting short of it. In this way I keep them going from day to day; watch them carefully, or it might happen that a hive full of bees-and at swarming point-might, if not watched and supplied with requisite food for existence, swarm or decamp. So by the time there is an abundance of honey abroad the hives are completely filled with bees and contain brood in every 
frame hive; and then it is that I put on my supers and discontinue stimulative feeding.

"In the place of the crown-board I place a sheet of five-thirty-second perforated zinc, and supers same size as hive and five inches deep. The supers are provided with bars which are sawn down the centre, enabling me to fix. a strip of impressed wax sheet without any difficulty. The bees generally take to these supers at once; and in a day or two the crown-board of super is removed, and I place a second super without top board between the first one and stock hive. The supers are also provided with traps [page 20I] to enable bees to leave after they have deposited their load, instead of passing through the stock hive. Now it sometimes happens that for some days the weather is fine and the bees begin storing a large quantity of honey in the supers (as they have no room in the stock hive), when suddenly the weather changes and cold sets in. As soon as this happens I remove the supers and watch the bees, and if they require small quantities of food I give it them, and when the fine weather returns they go again into the supers when replaced on top. In this way it sometimes takes only a week to fill a thirty-eight or forty pound super with some of the best honey that can be obtained. in this part of the country [Horsham]. I discard old. queens and generally select young and prolific egg-layers."

Agreeing as we do very much with the hints $\mathrm{Mr}$. Cowan gives, we commend them to the careful carrying out of intelligent and painstaking apiarians. 


\section{§ XI. REMOVIN(: BEES.}

A very great advantage that frame hives afford is the safety and convenience with which a stock of bees can be transported in them to any part of the kingdom or abroad: by a few additional arrangements stocks have even been sent in them to distant countries. In many districts hives are removed to moors and heaths in autumn, for the purpose of gathering heather honey. In this operation the frames are a great support to the combs, very much lessening the risk of a break-down and consequent loss.

The proper course to pursue in this case is to remove the crown-board, and nail across from side to side two strips of wood with smaller pieces fastened on them so as to secure each frame in position. Then nail a sheet of perforated zinc over the top; or in default of that the crown-board may be screwed down, when, if the two strips are not over an eighth of an inch in thickness, they will secure ventilation without allowing the bees to escape. The combs must be scrupulously carried lengthways, or they will break; and if they are new and the weather is warm, even with that precaution any but the most careful hand carriage is nearly certain to ruin them. If not going far it is best for the hive to be borne; between two; but if this is impracticable the vehicle used must at any rate have springs.

It is most urgent in making such a transfer that the 
most ample ventilation should be allowed. The bees are of course gorged at the time, and in that condition they are most particularly in need of air; while on the other hand the fact of their imprisonment, together with the shaking attendant on carriage, irritates them and causes them to make such a commotion, that without stringent precautions they would very probably be stifled, and of course the finer the colony the greater is the danger.

With an ordinary skep this supply of air cannot be ensured at the top, so that it becomes necessary, if the journey is to last longer than an hour or two, to invert the hive. This must be done with great caution and always in the direction in which the combs run. A sheet of perforated zinc on a board, or a piece of coarse canvas or cheese-cloth, may then be nailed or otherwise fastened with string over the base, thus taking the place of the floor-board, and it is needless to say that this should be done in such a manner that not a single bee can escape. If the journey is likely to be one of more than a few hours it will not do to employ any soft material, as it would in that time be gnawed through; but wire-cloth would answer as well as perforated zinc.

As a preliminary to any remove, smoke should be blown in at the entrance repeatedly during half an hour, after which it may be judged that all on the wing will have returned. For carrying a swarm, either a skep or box or anything will serve, and it must be secured and carried mouth upwards in the same way. 
§ XII. SUPPLYING NATURAL COMB.

We have spoken above (page 187 ) of the great value of sheets or strips of wax for assisting the bees in the building of their combs. But when, through another hive having lost its bees at an early stage, the combs themselves can be supplied them in good and clean condition, the advantage is very much greater. Such combs may be fixed in frame hives exactly in the same plan as is adopted on transferring full honeycomb (page 224).

Generally speaking the bee-keeper may be satisfied if he can simply insert pure white guide-comb with which to start the bees. Every bar, or if the comb is not plentiful, every other bar, should have a piece fixed to it in the following manner: Cut a piece of clean empty comb of the required size, say two inches square, not less; heat a common flat iron, with which slightly warm the bar; then melt a little bees'-wax upon it; draw the comb quickly over the heated iron, hold it down on the centre of the bar, giving a very slight movement backwards and forwards; then leave the wax to grow cold, and, if cleverly managed, the guide will be found firmly attached. Care must be taken that the pitch or inclination of the comb is the same as it is in the hives-upwards from the centre of each comb.

When a hive has been in use many years the combs become very black, and every bee that is bred in a cell leaves a film behind. It may be understood how in this way the cells become contracted, and the bees that are 
bred in them correspondingly reduced in size. After the lapse of, say, five years it may be necessary to begin removing the old combs. This may be done by cutting away the combs, or by substituting an empty frame for one with old black comb, gradually moving the frames towards each other. By taking two away in this manner in the spring or summer of every season, the combs in course of five years may all be reconstructed, and fresh clean ones be secured for breeding in, instead of the old black ones that otherwise would remain as long as the stock could live in the hive.

Guide-combs can also be used with glasses. These. may be filled, with great regularity, by adopting the following directions, which, we believe, have never before appeared in print :-

Procure a piece of clean, new, empty, worker honeycomb, which has not had honey in it (because honey will prevent adhesion to the glass); cut it into pieces of about three-quarters of an inch square. Gently warm the exterior of the glass (this we find is best done by holding the glass horizontally for a short time over the flame of a candle); then apply one of the pieces of empty comb inside at the part warmed, taking care, in fixing it, that the pitch or inclination of the cells is upwards-in fact, place the guide-comb in the same relative position that it occupied in the hive or glass from which it was taken. There is some danger of making the glass too warm, which will cause the wax 
to melt and run down the side, leaving an unsightly appearance on the glass; but a little experience will enable the operator to determine the degree of warmth sufficient to make the comb adhere without any of it being melted. It is hardly necessary to state that only the very whitest combs ought to be used. A short time should be allowed before changing the position of the glass, so that it may cool sufficiently to hold the comb in its place. Six or eight pieces may thus be fixed, so that, when the glass is filled, it will present a star shape, all the combs radiating from the centre. The annexed illustration shows the appearance of a glass as worked by the bees, in which guide-combs were fixed in the manner

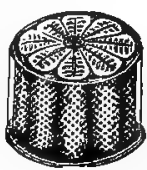
described above. The drawing was taken from a glass of our own, filled after being thus furnished. In the Old Museum at the Royal Gardens, Kew, may be seen a Taylor's glass, presented by us, some of the combs in which are elongated on the outside to the breadth of six inches.

We believe that not only does a glass present a much handsomer appearance when thus worked-and will, on that account, most fully reward the trouble of fixing guide-comb - but that more honey is stored in the same space and in less time than if the glass be merely placed on the hive in a naked condition for the bees to follow their own course. This mode of fixing guide-comb does not solely apply to the above-shaped glass, but is 
equally useful for all kinds of glasses. It is introduced in connection with this glass because, from its having a flat top and no knob, the regularity is more clearly apparent.

The working of bees in the bell glasses illustrates how tractable their disposition really is if only scope is allowed for the due exercise of their natural instinct. They have no secrets in their economy, and they do not shrink from our constant observation as they daily pursue their simple policy of continuous thrift and persevering accumulation. Yet it is only owing to the labours of successive inventors that we are now enabled to watch "the very pulse of the machine" of the bee commonwealth.

"Long from the eye of man and face of day, Involved in darkness all their customs lay, Until a sage well versed in Nature's lore, A genius formed all science to explore, Hives well contrived in crystal frames disposed, And there the busy citizens disclosed."

MURPhy's VANiẼRE.

\section{\$ XIII. APPLYING SUPERS.}

Supposing the hive to be a stock (page 8I), the super should be applied at the early part of the season, say, if fine and warm, at the latter end of April or beginning of May; but if the weather is then unfavourable it is better to delay doing so until a more genial temperature. If the colony is a swarm of the present year, two or 
three weeks should be allowed to elapse from the time of tenanting a hive before putting on the super; this delay is necessary to give the bees the opportunity of building combs in their new domicile, and of getting a store of honey for themselves before working for their master. The exact time * will, however, depend much upon the weather, and the same applies to the subsequent time occupied by the bees in filling the super. They will be the more incited to commence their work, and having commenced to continue it, if some warm covering is placed over the glass; at night, when much comb-building goes on, it is important to wrap it in flannel or worsted, or some warm material (a baize bag is convenient for bell glasses). A further inducement will be offered by the fixing of a piece of comb to the bars or ventilating tube, as the case may be. The cells on the outside or by the window are always the last to be filled, so that when these are sealed over it is safe to conclude that the rest are also complete.

When it is wished to use a super with a frame hive, the crown-board or roof of the stock hive must be taken away, the thin adapting or honey board, or perforated zinc adapter, taking its place-excepting of course where the crown-board is provided with openings for the purpose. The two long slits at the sides are to give admission to

* There is the nick of time before bees make their internal arrangements for swarming, but the difficulty is to know precisely when this is. 
the super. The bees will begin sooner, and work faster, if the bars are each furnished with guide-comb (as described in the previous section). Combs that have been left unfilled may be fixed to the bars, but these must be white and clean, as dark comb should not be used for super hives.

\section{§ XIV. REMOVING SUPERS.}

The operation of taking honey is best performed on a fine sunny day. The combs may be extracted singly, if wished, for consumption, substituting an empty bar or comb; or, should the bee-keeper desire to see a handsome super, he must wait until the bees have filled and sealed up all the combs, and then he may proceed to disconnect the super. If a bell glass, he will first pass a table-knife round it underneath the rim; then with a piece of string or fine wire, one end in each hand, he will very slowly sever the remaining connection with the board, so as to allow of the bees getting out of the way. Wait an hour or so for the commotion to subside and to give the bees time to repair broken cells and suck up spilt honey. Then raise the glass and blow in a little smoke, after which the slide that closes the roof of the hive may be inserted, and above it another piece of zinc that will cover the base of the super and hold the bees in it close prisoners. After having confined them in the glass for a short time you must see whether they manifest symptoms of uneasiness, because, if they do not, it may be concluded that the queen is among them. 
In such a case, replace the glass, and recommence the operation on a future day. It is not often that her majesty is in the depriving-hive or glass; but this circumstance does sometimes happen, and the removal at such a time must be avoided. When the bees that are prisoners run about in great confusion and restlessness, the operator may conclude that the queen is absent, and that all is right. The glass may be taken away a little distance off, and placed in a flower-pot or other receptacle, where it will be safe when inverted and the tin taken away; the bees will then be glad to make their escape back to their hive. A little tapping at the sides of the glass will render their tarriance uncomfortable, and the glass may then be taken into a darkened room or outhouse, with only a small aperture admitting light, which must be open; the bees, like all insects, make towards the light, and so escape (see description of "Bee-Traps," Chap. IV. § xviii.). The bee-master should brush them off with a feather from the comb as they can be reached; but on no account should the glass or other super be left exposed and unwatched, because the bees that have the opportunity will gorge themselves to their full, and speedily bring a host of others from the adjacent hives, who, in a very little time, would leave only the empty combs. It is truly marvellous how soon they will carry all the store back again, if allowed to do so. Unless the honey season is over, an empty glass should be put on to the hive in place of the full one, as it will attract the 
bees up, thereby preventing the too close crowding of the hive, and starting them to work more honeycomb.

If a bar or frame super, the first process is with a spatula to loosen the adapting-board from the stock hive after which the string is passed between them as above, putting in wedges on each side to follow the string. The smoking and expulsion of the bees follow as before. Another super will take the place of the one removed, or else the crown-board must be replaced.

Some apiarians, however, are of opinion that deprivation is more easily accomplished by disconnecting the super over night. In this case, after smoking the bees, wedge the super up all round about an inch from the board. Do this just before dusk, and leave it so for the night. The opening in the board remains unclosed, to allow of the bees joining the stock hive below, which they will naturally do for warmth. The super should receive its usual cover, and quite early in the morning, before the bees are much about, it will be ready for removal. The few bees that remain within may be speedily induced to quit. With a super that has an opening at the top it will be worth while to insert the nozzle of a pair of bellows, when a few puffs will be very efficacious in driving the occupants out.

\section{$\$$ XV. REMOVING FRAMES.}

It is well for a beginner to practise the directions for opening and shutting up hives, by using an empty hive 
until he becomes familiar with the handling of the frames. The first thing to do is to loosen the crown-board, or lid, with a knife, drawing a piece of string underneath it, to divide the wax or cement with which the bees make all secure. All this should be done very slowly, so as not to irritate the bees. In hot weather the crown-board may be loosened by a lateral movement; but sometimes, for want of care, this loosening of the lid disturbs the bees, and, as soon as it is removed, a number of them, enraged thereby, rush out and attack the operator. Especial care should be taken not to prise the lid upwards, by way of wrenching it off, for the frames and combs are generally secured thereto, and there is a liability of rending the combs with it; this will greatly irritate the bees, and be otherwise injurious. When a hive of bees is really enraged there is little chance of pacifying them; if the first tokens of anger cannot be appeased it is best to "give in" at once, and not attempt to perform any operation, but to shut the hive up and beat a retreat, benefiting by the experience in order to do better a day or so afterwards. There are various devices for intimidating or conciliating the bees, and one of these, already spoken of, is smoke. So next time the experimenter makes his attempt let him raise the lid an inch or so, and blow a few puffs of smoke into the hive, which will cause the bees to retreat. Previous to this he may give a puff or two at the entrance, which will help to produce the quieting effect. This is best done by 
using our tube fumigator, with a little of the prepared fungus lighted. Pipes or cigars are not convenient to use for this purpose when the head is enveloped in the dress. As soon as the lid is removed a few bees will fly out to learn the cause of such an interference. Conciliation should then be offered by having at hand a little sweetened water, which may be sprinkled, or rather. let drop, from a feather or a brush.* The sudden motion of the hand required in the act of sprinkling irritates the bees, so that, instead of making them our friends, they may become our foes. Mr. Langstroth recommends that a fine watering-pot, containing sweetened water, be used for the purpose. Care must be taken not to drench the bees; only just sufficient should be given to run down the sides of the combs, as well as sprinkle the top. As soon as the insects really understand that syrup is"being given them, they feast upon it, instead of angrily attacking the operator. Thus pacified, and with gentle treatment, but little difficulty will be found in proceeding with the work required. But the unskilled operator should on no account neglect to put on a bee dress and gloves, as described above. We would err on the side of caution, although there is an old saying that " a cat in gloves catches no mice;" and the apiarian will find that his fingers are not so free to work as he would like, for gloves make them rather clumsy in drawing up the frames.

* An objection to this is that robber bees are liable to be attracted from surrounding hives. 
These must now be gently prised up from front to rear; this may be done with a small screw-driver or other stout instrument with a wedged end to go into the notches. They fit loosely so as to permit of a slight movement from back to front; a lateral or sideway movement might kill the queen, or, if not so fatal as that, might crush some of the bees and injure the brood combs, which must be carefully avoided. Of course much depends upon the nature of the operation that has to be performed, whether or no all the frames should be thus loosened. If it be for making artificial swarms, or for any purpose that requires an interview with her majesty, the whole of them must be loosened, because it may happen that all the combs have to be examined, sometimes twice over, before she can be discovered. Bees are very apt to build their combs in a slightly waving form, and in extracting one it will be needful to make room both for the comb and bees upon it to pass without scraping the next comb, and there will be a difficulty if the apiarian attempts to draw out one comb whilst the other frames are located in their appropriate places. Where a dummy frame is provided the operation becomes simple; but if there is none, let the operator gently proceed to lift, say, the third frame slightly nearer to the fourth frame (allowing it to lodge on the little block that divides the notches), ${ }^{*}$ and the

* Many hives are now made without notches, so that it is necessary only to slide the frames. 
second nearer the third, so as to admit of sufficient space to lift out the end one. Very carefully and slowly he should lift the frame by taking hold, with thumb and finger, of the projecting shoulders that rest in the notch; and he must not let it touch or scrape the next frame or the sides of the hive, so as to crush. or irritate any bees.

After the end comb is thus removed it will be easy to extract the others, as there will now be plenty of room for drawing them out. If the bar-frame holder (page 192) is not at hand an empty hive of the same size will serve; and care should be taken that each comb occupies the same relative position that it did in the hive so that the same order may be afterwards retained when they are replaced.

In handling the frames it should be borne in mind that they are to be held perpendicularly. To gain a view of both sides of the comb when searching for the queen, or for any purpose requiring full inspection, the reverse side may, with a little dexterity in twirling the frame round, be brought to face the operator, without letting the comb break away by its own weight and so fall out of the frame, which it may do if allowed to deviate from its upright or downright position. If the beginner could see an experienced person perform the operation he would quickly understand how combs may thus be handled without any risk of a smash.

The bee-keeper should be on his guard not to tempt 
the avarice of bees by exposing honey, either in the comb or liquid, and also to be very tardy of opening frame hives in the spring or autumn. If needful to do so, soon after sunrise is the safest, because there will be few bees about, and the hive shoukd be taken, if convenient, to a quiet corner of the garden, many yards away from the other hives, and what is requisite done speedily, so as not to expose the honey to the scent of a host of robbers, who will most unceremoniously pillage and cause a terrible commotion.

When replacing frames in the hive, care must be taken not to crush a bee, and on no account must the frame be let down with a jerk, or the insects will become exceedingly fierce; it should be so slowly deposited in its. place that a bee on feeling the slightest pressure may be able to escape unhurt. The crown-board should be replaced by first resting its front edge along the back, and then sliding it forward, so that any bee upon it is pushed away instead of being crushed. Should the hive have its super on, the same directions may be followed. The super with its honey-board may be bodily taken away, and so placed and confined for a time that robber bees cannot find an entrance, and also be far enough from the apiarian to be out of danger of being broken or overturned by him.

It will be sometimes found, in cases in which the bees have not had sufficient storage-room, that they have carried their building operations outside and above the 
frames, or across from comb to comb. Such cells must be severed and the materials melted down for wax. There are also cases in which fine white combs of honey can be taken from the end frames of the stock hive; but probably not more than one comb could be removed in a season without impoverishing the bees.

\section{§ XVI. EXTRACTING HONEY.}

Those of our readers who prefer eating "run honey" to honey in the comb may be glad of some instruction as to the best method of separating the two. Beyond all question they will find this in the use of the honeyextractor (page 193), but in default of surch, and for extracting honey from combs made in supers, the following should be the course pursued :-

Take a sharp knife, and slice the combs on both sides, keeping the knife parallel with the partition wall, so that every cell may be laid open. Place these broken combs in a sieve, or on a piece of muslin stretched across and tied round the opening of a pan or large-mouthed jar. Allow the honey to flow out of the combs spontaneously, and reserve the squeezing process for a separate jar, so that the honey of the first-drained jar may be perfectly pure, both in appearance and flavour. That which has pressure put on it will be waxy in flavour and thick. Some persons recommend that the opened combs be placed in the sun, as the heat will cause the honey to run more freely. The great disadvantage of this is the 
temptation the honey offers to bees, who will be eager to gain a share. Honey, whilst in the combs, keeps remarkably well when left in the supers; if cut out, the combs should be folded in writing paper, and sealed up, so as to effectually prevent the free entrance of air; they should then be placed in a warm dry closet.

\section{$\S$ XVII. MELTING COMBS DOWN.}

Comb for which there is no use as such should be melted down into cake wax. Brood comb which has undergone its five years or so of service will probably not repay the trouble, and should therefore be thrown away. But if in good condition it should be put into a clean saucepan with plenty of soft water, and gently boiled or simmered over a clear fire till it is melted, when the wax will rise to the top. It must then be run through a strainer (never mind a little water going with it). into a stoneware or earthen pan, the sides of which have been greased to prevent adhesion. The refuse is then collected in a coarse bag and boiled again, a flat iron or other heavy weight being placed upon it to hold it down, and a plate or other false bottom beneath it to prevent its burning. By working this about with a rod or ladle a quantity more of wax will be brought out from it, and more still by, applying to 'the bag a wet rolling-pin upon a board also wet; the additional wax thus obtained may be added to the other, and the whole boiled again with a very little clean water and over a slow fire. Skim 
off the dross as fast as it appears, and then pour the whole again into the greased pan, and, after letting it cool slowly, scrape off the settlings. The above is in the main Mr. Cheshire's method. Another is that of Mr. Payne, who would pour the original boil into a canvas bag of about a quart, which should be laid on an inclined board in a tub, with cold water in it below the reach of the bag; then, applying the roller, the wax is all expressed at one process, and may be collected on the water and boiled again as before. The operation must be carried on where the bees will not be able to get admittance, or the odour will bring them in great. numbers.

Virgin comb, being free from cocoons or other rubbish, will not require the squeezing process, but may simply be melted into the pan, gradually cooled, and melted again. If the cooling is artificially delayed the wax will be all the clearer. If bleaching is desired, melt it again and pour it out so as to form thin streams or plates, and then lay these for a few days in the sun; take care however that they are not melted.

\section{§ XVIII. WEIGHING HIVES.}

One of the most effectual modes of ascertaining the condition of a hive is by weighing it. Such knowledge is most important at the close of the gathering season, in order that the bee-keeper may determine whether he ought to give his bees artificial food to enable them to 
live through the dreary winter. A knowledge of the numerical strength of the colony is also useful in enabling the bee-keeper to decide which hives will be benefited by being joined together, on the method explained in the article on "Uniting Hives."

A hive can very easily be. weighed if a Salter's spring balance be suspended near the apiary. The hive, having a strap or cord passed under and over it, crossing at right angles on the top, may be hooked on to the balance, so that the weight will be indicated on the dial. The annexed illustration represents a tripod stand, with a weighing-machine of the above-named construction, to which a hive with a super is attached.

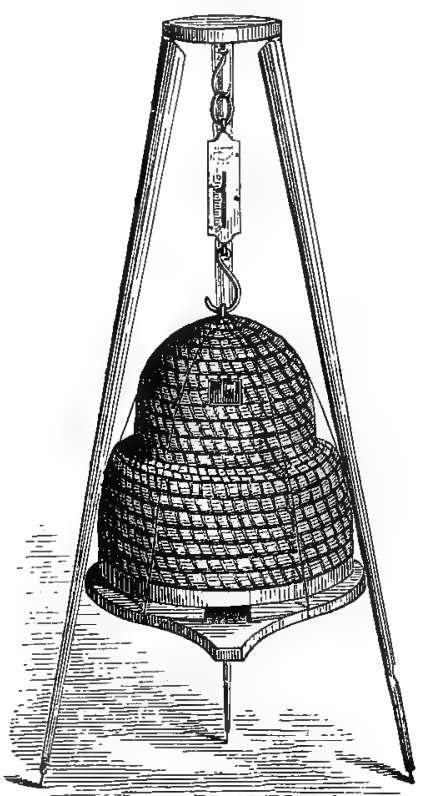

Such an arrangement will be found convenient for those bee-keepers who may not possess suitable sheds in their gardens where a hive could be thus suspended from a beam. To prevent the hive being swayed to and fro by the wind, three cords (gear ropes) might be attached 
therefrom to the three legs of the stand. The height of such a stand need not exceed four feet.

This contrivance is both portable and simple, and can be used from time to time; or, if the apiarian desires to have the hive constantly suspended, a water-proof covering might easily be made to drop over, and adapted so as to admit of being raised occasionally for ascertaining the weight shown on the dial. Much interest might be derived by watching the daily or hourly increasing store brought into a hive during the gathering season. Mr. George Fox, of Kingsbridge, and Mr. S. Bevan Fox, of Exeter, have for some years each kept one stock attached to a "Salter's Circular Spring Balance," suspended from a beam under a shed, and, from experience, found that from a hive so balanced a criterion may be formed of what other hives in the apiary are doing through the day.

Some interesting observations have been made upon this point. Baron von Berlepsch has had stocks which brought in twelve pounds of honey in a day; Kader in Mentz had days when one stock brought twenty-one pounds; Pastor Stein in Mentz had days when one stock brought twenty-eight pounds. The sap which a bee's honey-bag holds weighs but a grain, so that the bees, in this last case, must have made in one day over 160,000 journeys.

Many ingenious contrivances will, no doubt, suggest themselves for the observation of hives in this manner. 
For instance, instead of the cord being tied round the hive, three or four strong irons, with a screw at one end and a ring at the other (known by ironmongers as "eyes "), could be screwed into the floor-boards, to which the attachments might be made fast. It will scarcely be necessary to hint that great care is necessary that full provision should be made securely to support the increasing weight; a fall would be most ruinous, and terribly enrage the bees.

The weight of the hive should be marked on it when empty, so that the exact amount of its contents may at any time be ascertained. Experienced apiarians are able to judge of the weight of a hive by lifting it a few inches from the stand; or by looking in at the window of a stock hive a conclusive opinion may be formed as to the state of the colony. If the combs within view be well filled and sealed, it will be safe to consider that the hive contains sufficient stores to carry the bees through the winter.

\section{§ XIX. FEEDING.}

The bee-keeper, after the honey harvest, should ascertain the state of the stock hive, because it sometimes happens that hives which were very strong and productive during summer have been left poorly off for the winter. The bees, no doubt under the impression that those nicely filled supers would prove to them an ample sustenance, have given up the whole stock hive to the queen 
for breeding. If this be not looked after and rectified the colony will starve off; or possibly on some mild day in winter-even before all is exhausted - they will decamp as if for a swarm.

The apiarian must therefore ascertain the state of the stock hive at Michaelmas by means of a weighing machine. The weight, exclusive of the hive, ought to be from twenty to twenty-four pounds, and if not so, the bees must be fed till that weight is reached. This is done by the feeders above described (page 202), from which they suck the syrup as if honey-gathering, and then store it away, a quart in a day or so. The time of doing this should not be deferred later, as it is important that the food should be placed in the cells and sealed up, and they cannot secrete the wax for this purpose without a warm temperature; if it remained unsealed it would be liable to turn sour and cause disease. Again, at mid-winter and in very cold weather, bees, though they never become torpid like wasps, are in a state of dormant inactivity from which it is better not to arouse them.

On the return of spring it will again be essential to attend to feeding the bees, and this precaution must be exercised till May, when they will be able to take care of themselves. A little food in the spring, even when the store is not all expended, is of value as stimulating the queen to lay more abundantly, for bees are provident and do not rear the young rapidly when supplies are 
short. In this particular their intelligence is very striking; they have needed no Malthus to teach them that the means of subsistence must regulate the increase of population.

" Part of the wondrous whole by Heaven designed, Blest with some portion of ethereal mind, * The prescient female rears her tender brood In strict proportion to the hoarded food."

Evans.

Judgment has, however, to be exercised to avoid overfeeding, or else so many cells will be filled with honey that the queen can find none in which to deposit her eggs, and thus the progress of the hive will be seriously interfered with. It may also lead to the formation of drone cells-a thing to be avoided under any circumstances. But if the hive is thoroughly impoverished a more rapid process of feeding becomes necessary, and the honey should be poured between the combs. The bees will lick each other clean after this.

A very good syrup can be made by boiling three pounds of loaf sugar with nearly two pints of water. Sugar-candy and barley-sugar have also been each highly recommended for winter and early spring feeding, when small pieces can easily be pushed in at the top of the stock hive a little at a time. They have the advantage

* " His quidam signis, atque hæc exempla secuti, Esse apibus partem divinæe mentis, et hausțus Ethereos dixere."-Virgil, G. iv. 2 I9. 
of being unlikely to turn sour or to cause dysentery, as liquid food does when the bees are confined by bad weather.

It is of the most urgent importance that the bees should have water supplied them as soon as laying recommences, which should be early in January; if the weather is such as to prevent their leaving the hive, they must have it given them within. "For preparing the nourishment for the brood," says Dzierzon, "water is to the bees indispensable. Sooner could they dispense for a considerable time with pollen." It is also needful to them for the preparation of wax, and, adds the same writer, "when the egg-laying commences, some amount" of wax is usually produced equally soon, the bees requiring it for the covering of the brood cells." For a double reason therefore water must be supplied them; but in their eagerness to obtain it they are often drowned, so that it is well to give it them in shallow vessels containing pebbles for them to alight on. Salt also, says Dr. Bevan, is eagerly partaken of during the early part of the breeding season till the beginning of May, after which they seem wholly indifferent to it.

Such are the instructions for the regular process of feeding, though even this, with good management, should not be needed unless in exceptional circumstances. It has been remarked in the section on "Swarming" that a supply of food is advisable at such occasions also, but this is but an incidental trifle as compared with the other. 
The task of bringing a hive safely through the winter will undoubtedly dismay some of the inexperienced, and perhaps incline them to a preference for the fire-andbrinstone quieters. But a little attention to directions at the first will soon make the process tolerably simple; while as to the relative profits of the two methods, it must be recollected that the honey left in the stock hive for winter sustenance is not much of it of a saleable quality, and the value of it and of any extra syrup supplied will be far more than made up when in May a swarm comes off, and two colonies are possessed where on the old system there would have been none at all.

\section{\$ XX. WINTER PRECAUTIONS.}

The most important of these is the one discussed in the preceding section. There are, however, several other points which it is of consequence for the apiarian to observe.

First of all the hive itself must be suitably protected against climate, and if it be not of a description adapted to preserve warmth, a transfer must be made to one that is. Matting or other fencework may be erected to keep off piercing winds, and hay bands may be wound around the hives. Some hives constructed of glass are unsuited for winter occupation-even when kept within doors success is difficult and doubtful. They must be well wrapped up and covered in, and yet ventilation be allowed, for unless the moisture can pass off it will con- 
dense upon the inside of the glass, thus causing the combs to grow mouldy and directly interfering with the health of the bees. The use of such hives as the unicomb is best restricted to four months in the year, when bees are most active and interesting in their operations. An artificial swarm should be put into such a hive in May or June, and taken out again in September-never later, for there are often cold nights in October, when, the bees and brood being in near contact with the glass, and not being able to cluster as is their natural wont, they suffer greatly from the variations of temperature.

The population of each hive must also be well looked to, and if needful the uniting processes (page 229) must be carried out before the Michaelmas feeding. Hives that are to be so united should be gradually brought near together, if not so already.

The innermost combs, having been the ones most employed for breeding, will now be the ones least occupied with honey. It is therefore advisable to transpose them with fuller ones, in order to keep the bees clustered in the centre. They must not, however, have drone comb thus given them. In order to give them communication through the combs, "the apiarian should," says Langstroth, "late in the fall, cut with a penknife a hole an inch in diameter in the centre of each comb, about onethird from the top." This is for the purpose of allowing the bees in cold weather to move in a body, without going outside the frames, from combs where they have 
consumed the food to others that have honey within reach.

Ventilation is of great moment, but if the hive allows of its being given at the top, the entrance may then be narrowed so as only just to give free passage to the bees. Holes the size of a pin's head will allow the moisture to escape, and these' must be reopened as fast as they are propolised by the bees. The occurrence of a thaw is the time when ventilation is needed in its highest degree. It is a good plan to place a bell glass over the hole in the crown-board of a wooden hive, with a zinc trough round it to receive the condensed moisture. It is also requisite to clean the floor-board, say in February; but in this and other operations the bees should not be disturbed, for if they leave the hive when they are unable to fly properly, as is the case in very cold weather, they are likely to be lost.

What further directions belong to this head will be found in the next chapter under "Diseases" and "Enemies." Mr. Langstroth has this comprehensive sentence, the italics in which are his own. "If the colonies are strong in numbers and stores, have upward ventilation, easy communication from comb to comb, and water when needed, and the hive entrances are sheltered from piercing winds, they have all the conditions essential to wintering successfully in the open air." 


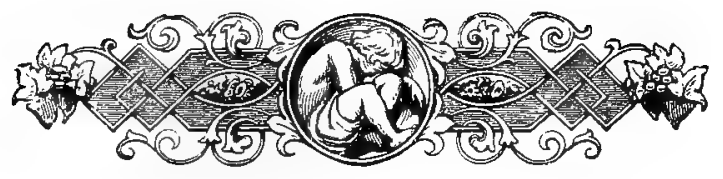

\section{CHAPTER VI.}

\section{MISCELLANEOUS INFORMATION.}

§ I. STINGS: THEIR PREVENTION AND CURE.

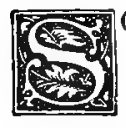

OME of our readers may deem us neglectful in having, as it were, left them to struggle through their bee-keeping novitiate without informing them how to avoid the annoyance of stinging from their docile but well-armed flock. Of course, having described the bee dress, we have supposed that the apiarian was clad, if not "in complete steel," at least in the head-gear and gloves, which will render him invulnerable. The best safeguard from the anger of bees-as, indeed, from the malice of men-is a quiet and peaceable spirit. Never strike at a single one. The apiarian will learn to handle his bees not only as "if he loved them "- -as the quaint angler says - but as if he fully believes that the bees love him. This they will do whenever he approaches and treats them gently. There are some cases of exception to this generally peaceable disposition of the bee; perchance a few bees are dyspeptic, and refuse to be pacified, let 
their master seek to bribe them never so wisely. Then, too, sometimes the bee-master himself may be dyspeptic, which the unerring olfactory sense of the bees speedily. detects, and their anger is immediately aroused. Some few persons, owing to constitutional peculiarities in their breath or insensible perspiration, are objects of constant animosity with bees, who, by driving them from the apiary, are giving a physician's advice without charge for a fee. Some of the choicest perfumes used by ladies are offensive to bees; and one may feel very certain that the "fine puss gentleman," who disgusted the brave Hotspur with his "pouncet-box" and praise of "parmaceti for an inward bruise," would have been speedily driven from an apiary in ignominious flight. For the same reason they will ferociously, and perhaps fatally, attack a sweaty horse, while they appear to have an equal antipathy to dogs. The hand should not be waved near them in sprinkling, as has already been remarked; nor should they so much as be pointed at when disposed to be out of temper. "Above all," says Mr. Cotton, "never blow at them; they will try to sting directly if you do." The distinguished success of Burnens in his examinations was attributed in part by Huber to his power of repressing his respiration. Confidence is another important specific: if a person covers his face with his hands the bees will attack and worry him at once and persistently; while a bee that is inclined to sting will often prefer a person who is watching at a 
supposed safe distance, judging such person afraid, and probably also seeing him better.

Again, when once a bee has stung, the scent of the poison has an infuriating effect upon others; therefore, says Butler, "you had best be packing as fast as you can." Höller, who lived in the same century, gives the advice, "Never approach the bees with your hat off; for a bee which may chance to have settled upon the head becomes easily entangled in the hair, grows angry, stings, and moreover calls others to its aid by its hissing passionate note." They have a dislike for woollen gloves, also to some kinds of leather ones. If used to attendants in light clothes it is said they will attack a visitor whose dress is dark. Electricity in the air appears also to ruffle them; and when kept at home by rain, or at night or early morning, they will resent any interference. In very hot weather, too, those inside the hive are sure to be in a bad humour. Von Berlepsch states that to disturb the combs at such a time may perhaps, by breaking them, even cause a civil war in the hive, as once happened to himself when exhibiting an Italian queen and brood to some over-curious tyros, and when, out of some seventy or eighty thousand bees, one-half were slain in the course of an hour. Lastly, they are in a stinging mood when they are queenless and before they have got over the agitation; also when in excitement during her majesty's nuptial excursion. The best time to choose for operations is when, with the hive in a normal con- 
dition and the weather agreeable, the great mass of the older bees are out upon the wing. It is these that there is the principal occasion to fear.

Occasionally even a skilful aparian may inadvertently crush a single bee; such a mischance is detected by the whole community with much more facility than by any "crowner's quest," and their prompt verdict decrees the summary punishment of the offender. There would be much less fear of stings if it were always remembered that bees are never aggressive. "Defence, not defiance," is their motto. They scarcely ever attempt to sting when away from the hive, and very seldom indeed at the time of swarming, for then they are gorged with honey. When molested by angry bees, do not attempt. to beat them off; the safest and best retreat is a green bush. Thrust your head into this, or, if no such refuge is near, in an emergency throw yourself on the ground, and, with face downwards, the bees will soon leave you.

Yet some people appear to think they must inevitably be stung if they meddle with bees, and for their sakes it is needful to explain why it is that a sting is painful, and how the wound inflicted by the bee may be cured. The weapon, as we see it with our naked eye-finer than a needle's point-is only the sheath, which lengthens or contracts like the subes of a telescope (see page I04). The dart, as before said, is barbed on each side, so that the bee, when very angry, is scarcely ever able to withdraw it, but- 
"Deems life itself to vengeance well resigned,

Dies on the wound, and leaves the sting behind."

There are, indeed, some happy mortals whose "blood such an even tenour keeps" that a bee-sting is to them simply a puncture, and nothing more. But unfortunately, as Langstroth puts it, "they seem to take a mischievous pleasure in stinging those upon whom the poison produces the most virulent effect." Dr. Bevan has suggested that lovers should subject themselves to the ordeal of a bee-sting, in order to prove, we suppose, that their temper is proof against "the stings and arrows" of any " outrageous fortune" that matrimony can bring.

It is the infinitesimally minute tincture of poison injected by the bee which causes inflammation. The first thing to do is to remove the sting, which, even when detached from the bee, will continue to penetrate still further into the wound. Next press the hollow point of a watch-key exactly over the place stung; this will express a considerable portion of the virus. Then dip the hand into, or bathe the part with, cold or tepid water, for the poison is volatile, and will thereby be dissipated to a great extent. On no account whatever should the part affected be rubbed; to do that will diffuse the poison and increase the inflammation. The specific remedy for a bee-sting is taught us by chemistry: the venom is an acid, which an alkali will immediately neutralise when brought into contact with it. Spirits of hartshorn will generally be found efficacious, and should therefore 
always be kept in an apiary. There are also several other remedies more or less effectual, according to the special constitution of the patient. A strong infusion of tobacco-water applied to the wound after the sting has been extracted is a specific for many persons; others find relief from the application of a sliced onion, while Frau Lieb, of Jassy, declares nothing so efficacious as one's own saliva. Two preparations may be named as màde especially for the purpose-the "Ledum Palustre," and Dr. Pine's " Bee-keeper's Lotion."

We have heard the remark from several who have kept bees for years, that the poison from a sting has little or no effect on them; after receiving many inflictions their flesh appears to become so little affected that the swelling and pain at one time experienced no longer trouble them. Herr Kleine recommends bee-keepers to subject themselves intentionally to stinging, in order that in two years their system may become insusceptible to the poison. No doubt those who are so stoically inclined will duly appreciate and gratefully acknowledge the advice.

Boiling water poured on to bees makes a bee tea which has been highly recommended in bad cases of strangury. Bee poison itself is a specific with homceopathists, but one bee-sting is not cured by a second, as $\mathrm{Mr}$. Langstroth satisfactorily demonstrated at the cost of much personal pain. 


\section{§II. POSITION OF HIVES,}

Some writers on bee-culture attach much importance to the particular position in which an apiary stands and the aspect towards which it faces. A southern, or rather a south-eastern aspect, is the one which we recommend. Our reason for this preference is that we deem it very important for the bees to have the first of the morning sun. Bees are early risers, and should have every inducement given them for the maintenance of so excellent a practice. A few years since, many strong opinions were expressed in favour of a northern aspect for hives. The chief reason given for those opinions, though very plausible, appears to us to be a very partial and inadequate one. It was said that, when the hives face the south, the bees may, like the incautious swallow in the fable, be tempted to fly abroad in the transient winter sunshine, and then perish in the freezing atmosphere when a passing cloud intervenes. But it is a very easy matter, if considered needful, to screen the entrance by fixing up matting so as to intercept the rays of the sun. At our own apiary we make no alteration in winter, under the belief that the bees will take care of themselves and that they seldom venture out when the weather is unsuitable.

Columella gave a number of directions on this point, the essence of which may be stated as follows. If in a valley it will be easier for the loaded bees to return 
home than if on a hill; it must not be "exposed to noisome smells, nor to the din of men or cattle;" it should be near a shallow running strean with pebbles for the bees to alight on, but not near deep water with steep banks; and the trees near should be low, and "convenient for manipulation in swarming.

The vicinity of sugar warehouses, or other places of temptation of the kind, is certain to prove prejudicial if not fatal to an apiary. The beeish instinctive love for sweets, like all other good things, has its bad side, and here we see it developed into a propensity to acquire on the shortest and easiest though most suicidal method. Mr. Langstroth tells us that he once furnished a sweetshop will gauze windows and doors, when the bees "alighted on the wire by thousands, fairly squealing with vexation," and in desperation they descended the chimney, which had to be stopped in like manner.

\section{§ III. PASTURAGE FOR BEES.}

"Bees work for man; and yet they never bruise Their master's flower, but leave it, having done, As fair as ever, and as fit for use."

Apiarians generally agree in the opinion that very little can be done in the way of providing any special forage for bees. Yet bee-fanciers are always interested in observing which are the flowers that the bees prefer; and there are certain well-established conclusions as to the kind of districts and seasons which are the likeliest 
to produce a good honey harvest. There is an old saying, that a country which produces the finest wool also yields the best honey; and a pastoral district is decidedly better than one under tillage. The principle of the matter is, that the bees are best suited with a long dry season-an early spring, a hot summer, and a late autumn. As not one of these blessings can be commanded by the apiarian, his art must be applied to providing some mitigation of the injury suffered by the bees when the season is short or wet. For early spring, the crocus, the blue hepatica, and the violet all afford good supplies of pollen and honey, and, if cultivated near the apiary, will be of great service when the wild flowers are backward. All varieties of the willow and poplar furnish early supplies of honey, as well as of the propolis to be presently described; the blossoms of the gooseberry and currant are very useful for the bees in May. Wet, when it enters flowers of any kind, prevents the tongue of the bee from reaching the secret source of honey. On this account it is well to know, as does the bee, that the drooping blossoms of the raspberry escape the effect of the showers, and honey is gathered from them when other flowers are drenched within as well as without. For a similar reason borage (Borago officinalis) is valuable for bees, and also because that plant continues to flower until the frosts set in. The honey both from raspberry blossoms and borage is very superior. Mr. Langstroth says, that "the precipitous and rocky 
lands of New England, which abound with the wild red raspberry, might be made almost as valuable as some of the vine-clad terraces of the mountain districts of Europe." The golden rod and also asters afford superior honey for autumn gathering, Dzierzon strongly recommends buckwheat being sown in the winter stubbles on behalf of the, bees, and he tries hard to persuade farmers that it is to their interest to cultivate it. It should be named that all the ordinary fruit blossoms, especially that of the apple, supply abundant store for bees.

It is, however, to wild or field flowers that the beemaster must chiefly look for the raw material on which his myriad artisans shall exert their skill. The white clover of the pasture, ${ }^{*}$ the wild thyme on the hill, the heather on the moors, the furze and the broom on the sandy waste, offer exhaustless stores for a greater number of bees than can ever be located near them. Lime trees, when in blossom, and mignonette are also most valuable resources; and there are two or three peculiar sources of honey which one would not have suspected, as, for instance, the blossoms of the onion plant, of turnips, and, in still greater degree, the flower of the mustard plant.

In those districts of England where mustard seed is cultivated so extensively, it would be well worth while for the farmers to keep large colonies of bees. Another,

* It is a good practice to induce the owners of adjacent fields to sow clover seed. 
296 MISCELLANEOUS INFORMATION. [CH. vi.

but a very uncertain, source of honey is the "honeydew," which in some seasons appears in large quantities on the leaves of the oak, the lime, and some other trees (see below).

\section{§IV. HONEY.}

All that need be said in this place is a few observations upon honey considered in itself. Practically, but not absolutely, it is destitute of nitrogen, which is the flesh-forming principle in food. It has been much contended whether or not it undergoes any transformation by being swallowed by the bee. Dzierzon and others have maintained that it does; Cundelach and I)r. Dönhoff have taken the contrary view, and Von Berlepsch has come round to the same, which it will be seen is also held by Schmid and Kleine, from whom we translate the following description of this article :-

"Honey may be of diverse origin : it is either nectar or bud honey, or leaf honey (the so-called honey-dew), or aphis honey [another form of honey-dew], or fruit honey. The sources of honey unfortunately do not flow with the same strength everywhere and at all times.

"For collecting the honey, bees are provided with tongues and honey-stomachs. . . . In the stomach the honey undergoes no transformation; only by evaporation in the cells does it receive its subsequent distinctive character. After sufficient evaporation the cells that contain it are sealed over with flat wax lids. 
"Between different honeys there exists an essential difference in respect of aroma, taste, colour, and composition. Whether there is such a thing as poisonous honey is a question upon which opinions are divided.

"In trade honey is often adulterated with starch, syrup, sugar, and 'more 'pernicious ingredients, which can easily be detected by chemical and microscopical analysis. The crystallisation of honey differs essentially from that of sugar or of a mixture of honey and sugar."

On this matter of adulteration we have been favoured with some remarks from a well-known apiarian who writes under the name of "A Lanarkshire Bee-keeper." $\mathrm{He}$ recommends the purchaser to take a common testtube, nearly fill it with water, and add about one-twelfth as much of the honey; when dissolved it will be turbid if the honey was pure, but clear if sugar had been mixed with. it. Those who wish to proceed further may add a few drops of concentrated nitric acid, and then let the tube stand for a week, at the end of which time the honey will be precipitated, but the sugar remain in solution, and then by filtration the quantities may be found.

Honey, like most vegetable products, should be fresh every year. It may easily be kept from one season to the next ; but after that, unless carefully stored in a warm temperature, it will crystallise in the comb, or perhaps ferment if separated therefrom.

Bees will often gather honey from the laurel, ivy, or 
other sources more agreeable to themselves than to us, in which case there is little choice but to leave the benefit of it to its producers (see page 97). Again, the fact related by Xenophon in the retreat of the Ten Thousand, that bees in Asia Minor extracted honey from plants which had not only a disagreeable but a poisonous tendency to man, shows that it is quite possible, where such noxious plants abound, for the bees to extract the juices without any injury to themselves.

\section{§. V. POLLEN, OR BEE-BREAD.}

Bees, when fully grown, feed almost wholly on honey; but the larvæ require for their development a more substantial kind of nourishment. Such solid fare is found by the bees in the pollen of flowers, a farina which contains the nitrogenous element of which honey is nearly destitute. The body of a worker bee is covered with hairs, to which the pollen adheres when, by contact with the bee, it is rubbed from the anthers of flowers (see page 88). Dewy mornings or humid bowers suit the bees for the gathering of the pollen. If the atmosphere be too dry for kneading it into pellets, they roll themselves in the blossoms, and on their return, with assistance from others, brush off the farina into the cells intended for it. A portion of this "bee-bread" is taken at once by the "nursing bees," who are supposed to subject it to some change before offering it to the larvæ; but the greater part of the pollen is stored away and reversed 
in the cells for future use. In April and May the bees are frequently busy "all the day" in gathering pollen, and often one community of bees will collect about twenty pounds weight of "bee-bread" in one season.

One of the objects of the apiarian is to assist the bees in providing for the nurslings of the hive. Dr. Dzierzon first suggested the plan of providing the bees with "unbolted rye meal" as a substitute for the farina of flowers. He had observed that, in early spring, before the flowers were open, his bees had entered a neighbouring cornmill, from whence they returned laden with rye flour. Since his discovery, some keepers, in early spring, have placed rye or wheat meal near the apiaries; to this artificial store the bees repair by thousands, and seek to rollick in the enjoyment of such plenty, many of them returning to the hive as dusty as millers. The object in thus supplying them is that the brood may be rapidly brought forward, and early swarming induced. In this way a few pounds of rye meal, at one penny per pound, may tend to the production of very many pounds of honey of twelve times the price.

In the British Bee fournal there is a recommendation to sprinkle pea flour amongst deal shavings in any open vessel, and place this near the hives so that bees have access to it. We can endorse this recommendation, for we know that it is freely taken by the bees.

If the bee-keeper ascertains that for some interval no pollen has been conveyed into any particular hive he 
may regard it as a sure sign that no young bees are there hatching, and consequently that the hive is without a queen. Mr. Mahan, of Philadelphia, once met with a hive which no pollen had been seen to enter for twentyeight days; he put a queen into it, took out his watch, and observed in three and a half minutes a bee come in with pollen on its legs-many more speedily following !

Some remarks on the services which bees render to flowers will be found in the section upon "Faculties and Functions" (page 55).

\section{§. VI. PROPOLIS, OR BEES' CEMENT.}

"Propelis" is a Greek word which originally signified "the outskirts of a city," but was adopted by Latin writers on bees to denote the sticky substance with which these city-rearing insects protect their outskirts. It is "a resinous substance, very tenacious and semitransparent," which is indispensable for the bees as a cement wherewith to fix their combs and fortify their hives against intruders.* The bees, in working the propolis, often soften it by blending it with a portion of wax; but they have to extract it in its natural state directly from the bark and buds of certain trees. The bark of the willow, the leaf-buds of the poplar and alder, and the unopened blossoms of the hollyhock are very usual sources of propolis. In the case of a new swarm,

* Egyptian bees, however, substitute wax, as stated on page 50. 
as bees must have this glue before they can begin to build their combs, they will resort to most unlikely places to obtain it. Sometimes they will enter a paint-shop and attack the varnish, and it is said they have been seen to obtain propolis from the pitch and rigging of a ship. These circumstances afford intelligible hints to the apiarian, who, if his bees have not easy access to firs, poplars, or willows, will provide some glutinous or resinous matter which may serve for a substitute. The extraction of propolis costs the bees very considerable labour, which they should be relieved of as much as possible in order to facilitate their great work of honeygathering. Bees choose the warmer part of the day during which to gather propolis, as then it does not so rapidly stiffen. Frequently when they arrive at the hive it has become so hard that the other bees are scarcely able to gnaw it from their thighs.

With propolis bees fasten down their hives, stop up crevices, to exclude moths and ants, and sometimes use it to narrow their doorways against the invasion of wasps. Extraordinary anecdotes are told of the prompt and ingenious use they make of this substance. Réaumur relates that, a snail having been observed by the bees on the window of the hive, they proceeded to glue the shell to the glass, and there sealed down the intruder in hopeless durance. In another case, that of a slug, the bees, having slain it with their stings, were quite unable to remove it from the hive. With wonderful foresight they 
then proceeded to secure their community from the noxious effects likely to arise from the decay of the carcase; and this they did by completely enveloping it with a coating of impervious varnish. Huish relates a similar occurrence in the case of a mouse caught in a hive by bees. Propolis yields benzoic acid, and contains some aromatic properties.

\section{§ VII. SECRETION OF WAX.}

We have already made some remarks upon wax in the Chapter on "Anatomy and Physiology." The subject is one that even yet has not been thoroughly cleared up, though the discoveries of Hornbostel and Huber have demonstrated that instead of being a vegetable product extracted from pollen it is a fatty secretion of the bees themselves. But later observers have come to the conclusion that though not obtained direct from pollen, that food is essential to their power of secreting it. Cases are certainly recorded in which combs have been built when the bees had for several days been deprived of the means of procuring this food, but it has not been shown that bees which have never had access thereto have still the power of secreting wax; Langstroth on the contrary asserts that some pollen is alzays found in the stomach of wax-producers. So Dzierzon: "Even if wax, as a fat, is [like honey] a substance destitute of nitrogen, and even if feeding upon honey or sugar is alone sufficient to enable the bees to prepare it, it does 
not therefore follow that pollen is not necessary for its continued production. For, as already remarked, the bees can prepare food for their young for a considerable time without pollen, yet no one would assert that this is unnecessary for the nourishment of the brood. In the one case as the other the bees are sustained by a certain store taken into themselves, but which by degrees becomes exhausted." To yield one pound of wax they require to consume from thirteen to twenty pounds of honey; so that it would seem as if honey was the foodforming principle of the wax, and pollen the stimulant that imparted to their own organs the capacity for effecting the transformation.

The bees, it need hardly be stated, elaborate this secretion by clustering themselves in festoons and curtains, in which they remain, the fore legs of one clasping the hind ones of another, perfectly still for some twentyfour hours, at the end of which time the scales are found exuding around them, as mentioned in our earlier reference.

The little plates of wax are withdrawn by the bee itself with its hind feet, and carried to the mouth with its fore feet, where the wax is made soft and ductile; vigorous shakes of the body assist in detaching the plates, and the floor-board is afterwards found covered with the pieces that have fallen. One by one some of them then leave the cluster and deposit their burdens in rough masses, which are subsequently wrought by others into the hexagonal form. But it seems feasible that the 
lower bees pass their secretions up the living ladder to the uppermost ones to undergo this double process. The rapidity with which comb-building progresses at such times would lead to the supposition that there is a division of labour of this kind among them, just as our labourers convey building material to the artisans on the scaffold above. This work of comb-building is carried forward in warm weather, for a cold temperature interferes with the secretion of wax. Von Berlepsch declares that he has known cases in which a hive has built three hundred square inches of comb in a single night !

The secretion of wax, and the method of its adaptation by the bees, are thus admirably described by Evans :-

"So, filtered through yon flutterer's folded mail, Clings the cooled wax, and hardens to a scale. Swift, at her well-known call, the ready train (For not a buzz boon Nature breathes in vain) Spring to each falling flake, and bear along Their glossy burdens to the builder throng.

These in firm phalanx ply their twinlkling feet, Stretch out the ductile mass, and form the street, With many a cross-way path and postern gate, That shorten to their range the spreading state. Those with sharp sickle, or with sharper tooth, Pare each excrescence, and each angle smooth, Till now, in fnished pride, two radiant rows Of snow-white cells one mutual base disclose. Six shining panels gird each polished round, The door's fine rim with waxen fillet bound, While walls so thin, with sister walls combined, Weak in themselves, a sure dependence find." 


\section{§ VIII. ROBBING.}

We have had many times to allude to the truly sad character which our little favourites bear in this particular. Directions as to the precautions necessitated thereby have been given pretty generally in connection with operations in which it is to be feared, so that one or two general remarks are all that need be added here. Von Berlepsch stoutly maintains that there are no professional robbers amongst the bees, but that all are ready to lend a hand in a job of the kind when it is to be had. This is probably true in great part, but not to the extent that there exist no individual differences in the strength of the propensity, and the remark quoted from Dzierzon on "black" bees (page 72) may be taken as expressive of the other side of the truth.

It is queenless stocks, nucleus hives, and weak colonies in general that have most need for protection against enemies of their own kind. By keeping the entrances narrowed, and feeding carefully without leaving a trace of food about, the enticements to plunder may be kept down as much as possible. It has been recently recommended in extreme cases to saturate a rag with carbolic acid diluted with water (fully half); this will effectually repel all except those who have no other home to which to betake themselves. But it will be obnoxious to these latter as well, so should not be lightly resorted to. 
Mr. Langstroth has a capital little bit about a highhanded piece of audacity that has been occasionally observed in our insect. House-robbing, it seems, is not bad enough for them, but they will even go the length of acting as highwaymen and garotters. For thus runs the story of their waylaying and despoiling the humble bee: "Seizing the honest fellow they give him to understand that they want his honey. If they killed him they would never be able to extract his spoils from their deep recesses ; they therefore bite and tease him, after their most approved fashion, all the time singing in his ears, 'Your honey or your life,' until he empties his capacious receptacle, when they release him and lick up his sweets."

\section{§ IX. DISEASES OF BEES.}

Dysentery is a disease produced either by long confinement, by dampness, or by feeding in the winter. The first thing bees do when disturbed is to fill themselves with food, so that in winter weather, when they cannot get out to void their fæces, hives should not be meddled with, otherwise the complaint may be brought on. It is also engendered in many instances by the state of the weather in winter months, and is indicated by the yellow colour of the excrement, and by its being voided upon the floors and at the entrance of the hives, which bees in a healthy state generally keep clean. All that can be done for them when affected is to see that there is plenty 
of wholesome food in the hive, and to well clean or to change the floor-board, and so produce cleanliness.

The more formidable, but happily less common, malady of "foul brood" does not attack the bees themselves, but affects the larvæ, by causing them to putrefy in the cells, thus destroying all hope of the rising generation. Bees are exceedingly fond of their young, and are greatly dispirited when their hives are in this plight. In common with most pestilential disorders, no satisfactory cause is assigned for its first appearance. Some apiarians contend that "foul brood" is another name for chilled brood; others, that the queen, by a freak of nature, deposits some of her eggs the wrong way upwards, and that these putrefy in the cells, and contaminate the others. Whatever may be the origin, one thing is very certain-_" it is catching:" there is, however, in the circumstance of the adult bees and of those about emerging from the cells not being injuriously affected thereby, a great help to its eradication, as will presently be shown.

There are two kinds of foul brood-one of which is dry and not contagious, the brood merely drying up in the cells; from which partial character it is probably within the power of the bees themselves to overcome. In the other kind, instead of drying up, the brood remains dark and slimy in the cells, and emits a most unpleasant odour, perceptible at some distance from the hive. 
In the year $\mathrm{I} 848$ Pastor Dzierzon lost a large number of stocks from this disease; he however was enabled to banish it from his apiary, and communicated to a German bee-journal very wholesome advice, which Mr. Langstroth quotes, and from which we make an extract: "When the malady makes its appearance in only two or three of the colonies, and is discovered early (which may readily be done in hives having movable combs), it can be arrested and cured without damage or diminution of profit. To prevent the disease from spreading in a colony there is no more reliable and efficient process THAN TO STOP THE PRODUCTION OF BROOD; for where no brood exists none can perish or putrefy. The disease is thus deprived both of its aliment and its subjects. The healthy brood will mature and emerge in due time, and the putrid matter remaining in a few cells will dry up, and be removed by the workers. All this will certainly result from a well-timed remoral of the queen from such colonies. If such removal becomes necessary in the spring or early part of the summer, a supernumerary queen is thereby obtained, by means of which an artificial colony may be started, which will certainly be healthy if the bees and brood used be taken from healthy colonies. Should the removal be made in the latter part of summer, the useless production of brood will at once be stopped and an unnecessary consumption of honey prevented. Thus, in either case, we are gainers by the operation."

In cases where the disease assumes a more malignant 
character-in other words, "has got ahead," through " not being nipped in the bud "-it will be well to take notice of another quotation from Mr. Langstroth's book: "In the spring or summer, when the weather is fine and pasturage abounds, the following cure is recommended by a German apiarian: "Drive out the bees into any clean hive, and shut them up in a dark place without food for twenty-four hours; prepare for them a clean hive, properly fitted up with comb from healthy colonies; transfer the bees into it, and confine them two days longer, feeding them with pure honey." ",

The late Mr. Woodbury's apiary was severely attacked by this disease in the spring and summer of 1863 . The writer happened to be on a visit to him at this juncture, and witnessed him withdrawing infected combs from hives that were literally masses of corruption, the broodcells of which, on being opened with a pointed instrument, revealed the dark brown slimy matter before alluded to, and from which arose a most unpleasant smell. Mr. Woodbury communicated to the Fournal of Horticulture, of July 2 1 , $186_{3}$, an exact and graphic account of his misfortunes, heared "A Dwindling Apiary." Finding that the removal of the putrid matter must be simultaneously effected and the bees driven out and placed in hives that had undergone a complete purification, he set about endeavouring to accomplish his object, and was so far successful that he was able to furnish an article to the before-named journal of August 
4, same year, under the more cheerful title of "Convalescent," in which he says : "First, let me endorse the opinions both of Dzierzon and Rothe, that, except under very especial circumstances, it is unadvisable to attempt the cure of a foul-breeding stock: better, far better, to consign its inhabitants to the brimstone pit; the hive itself, if a straw one, to the flames; the comb to the melting-pot; and appropriate the honey to any purpose, except that of feeding bees."

Mr. Woodbury further says: "Before starting, it was requisite to ensure the transfer of the bees to unpolluted hives; and here I found that, Dzierzon declares that every hive that has contained a foul-breeding colony should be exposed to the sun and air for two years before being re-stucked. In my own case this was simply impossible, and I therefore adopted the practice of another German writer on the subject, viz., to scrape out the hive very carefully, wash it all over with a saturated solution of chloride of lime, keeping it closely shut up for twenty-four hours, and then, after thoroughly washing it with clean water, exposing it to the sun and air until the smell of the disinfectant had passed off. This method has the advantage of enabling one to use a wooden hive again after a lapse of a couple of days, and is, I believe, thoroughly effectual."

Mr. Woodbury then captured the queen, secured her in a cage, and placed her in a clean empty hive; all her bees were brushed from their combs into it as rapidly 
as possible, in order to prevent their carrying much of the infected honey with them; whilst the combs themselves were set draining out of the bees' reach, and consigned as quickly as possible to the melting-pot. After the lapse of three or four days, the queen (still imprisoned) and bees were again transferred to another clean hive, furnished with a few pure combs, and in this they were suffered to remain, their queen being released in a day or two, as soon as they appeared contentedly settled. Mr. Woodbury gives another important hint, that operations of this kind with tainted combs should be performed out of reach of robber bees from adjacent hives, lest they should carry the infection to their respective houses. By the before-mentioned process, he succeeded in completely extirpating foul brood from his apiary in 1863 , and had no return of it afterwards. English apiarian writers have made so little allusion to this disorder, that some of our older bee-keepers contend that modern hives and foreign bees have something to do with bringing it about. To show that the disease made its appearance in former days, there is a chapter on this subject in Bonner's "Bee-Keeper's Companion," published-at Berwick in 1798 , entitled "An Uncommon Disaster which sometimes, though rarely, happens to Bees." Bonner, after recounting therein his observations of the dwindling state of his own apiary, for which he could not account, says: "He saw plainly that the young were all going backward in the cells, and that he 
looked down between the combs, but was unable to proceed for the stench that the rotten maggots produced." Mr. Langstroth writes that "Aristotle speaks of a disease which was accompanied with a disgusting smell, so that, there is reason to believe that foul brood was known two thousand years ago."

Our own observation leads us to the belief that foul brood is caused in many instances by feeding stocks with fermented honey or with syrup likely to ferment. Alb liquid food should be boiled before it is given to the bees, to destroy any impurity and to make it wholesome, for in several cases we have found stocks to be infected that have thus been incautiously fed.

Suspicion may be aroused of the existence of foul prood in any kind of hive, firstly, by the unproductiveness of the bees, also by the diminishing number at the entrance; and if very far advanced the odour will be very noticeable a few feet from the hive. But in barframe hives an experienced eye will on examination readily detect the malady if present by the dark unwholesome appearance of the comb, and by the caps. covering the diseased brood being sunken rather than raised. Small perforations are noticeable in some, and in others the grubs may be seen rotting in unsealed cells. We know of no cure, but some foreign apiarians of . experience recommend injecting a solution of salycilic acid into every diseased cell; others say that carbolic acid will effect a cure; we know that the latter is very. 
distasteful to the bees and therefore should not be disposed to advise its use. The best thing to do is to break the hive up at once. The bees may be saved by being put in quarantine a short time, and the hive cleansed as before mentioned; but if the hive be a valuable straw one, after cleansing and scraping, the interior should be coated with shellac dissolved in spirits of wine. If a frame hive it will be best to have new frames rather than to attempt to cleanse the old ones. To allow a hive to die out is very dangerous, because the bees from other hives will rob and carry the infected honey to their combs, and thus every colony within beeflight is liable to be polluted.

It may be well to give a hint about using old combs. Any that is very black should be rejected, because the disease is sometimes present in old hives, and also because each maggot leaves behind a silken film which lines the top, sides, and base of the cell, also a slight deposit of excrement which the bees do not clear away; thus the cells grow smaller and the bees reared in them are also diminished in size, although the bees do add a little to the mouth of the cell. On this account we would recommend all when purchasing stocks to see that they are not very old. The combs of a hive may be said to be the furniture and storehouse of the bees, which in long service wear out and to some extent become after a lapse of years unfit tenements for use. To remedy this, Nature, always true to her laws and careful to make provision for 
the perpetuation of the species, may have ordered that swarming should be the means of establishing fresh colonies freed from the disadvantages and contamination of the old. The late Mr. J. H. Payne, of Bury St. Edmunds, had a straw skep that had had bees in it without intermission for twenty years, but it is not advisable to keep them so long, although, with a little judicious pruning, much may be done to remedy the defects of old combs. Our own experience for keeping a stock does not extend beyond ten years.

When we take into consideration how sorely our farmers are perplexed by the cattle plague, known as the rinderpest, concerning which so many conflicting opinions exist (and the same may be said of the recommendations for its cure), can we wonder that our little favourites should occasionally be liable to disorders of this sort which puzzle even experienced bee-keepers? In the hope of allaying unnecessary alarm, we would just add that foul brood is not a very general complaint, and, so far as our observation extends, has been most fatal in large experimental apiaries, where extensive propagation has necessarily had to be pushed forward. Witl the experience and advice already gained, this disorder may now be said to be considerably deprived of its terrors.

We find several other complaints described at more or less length by Von Berlepsch, but to which a very brief allusion will here suffice. One he speaks of under the self-explaining title of "thirst-need," as to which he rightly 
remarks that it will be the bee-keeper's own fault or inexperience if his bees are ever allowed to suffer from it. Then there is "mad sickness," which consists in tumbling about as if intoxicated, and which Dzierzon says he meets with nearly every year, and conjectures to arise from partaking of poisoned honey-he suspects the honey to be naturally poisonous, since he observes this complaint almost regularly at the time when the mountain ash is in bloom. The next is "wing lameness," which the Baron conjectures may be the real disorder just spoken of as madness. Lastly we have the "thread fungus," which is a growth found by Leuckart and Dönhoff in the stomach and intestines of several bees, and which they pronounce contagious. Our author does also include among the "sicknesses" of bees such irregularities as rising against and murdering their queen; but one would think that this was rather a political disorder, or else a case for a commission of lunacy.

The apparent fungus growths seen occasionally on the heads and bodies of bees have been found to be nothing more than the effect of smearing with the gummy pollen of orchids or with other glutinous vegetable juices, on which afterwares ordinary pollen has collected and thus caused the appearance of tufts or patches.

$\S \mathrm{X}$. BEE ENEMIES.

Bees have few worse enemies than wasps in autumn. The most effectual method of checking their invasion of 
hives is to have as narrow an entrance as the bees can do with. If a stock is not very weak in numbers the bees will be well able to guard a small aperture, and can repel the attacks of these insidious and merciless robbers. On this account the entrance to our cottage hive, as described at page I I 4 , may be used.

The bee-keeper is interested in preventing the increase of wasps; it is therefore a good practice for him to set a price on queen wasps in the spring, the death of one of them at that time being equivalent to the destruction of a whole nest.

Should nests be found in the neighbourhood of an apiary, their annihilation must be accomplished either by blowing them up with gunpowder-an operation well understood by most country lads-or any other effectual method. The late Mr. Payne recommended that a small quantity of gas tar should be put into the.mouth of a wasps' 1 est, and if then covered with earth, the total destruction of the wasps will be accomplished without further trouble. But to use blazing straw for the purpose is always dangerous in country districts. We have lately heard of a very ingenious and successful mode of entrap. ping and killing wasps. Place some sugar or strongly sweetened compound on the ground in a garden, and place over it a square hand-glass, wedged up an inch or so all round. On this glass, which should have an opening at the apex, lodge another, but a sound one. The wasps, attracted by the sweets, will soon crowd under 
the lower glass, and, when they have well feasted, will ascend into the upper one ; there, between the two, they soon become scorched and perish by the heat of the sun shining on the outer glass.

Some seasons are very productive for the increase of these prime pests of the apiary, and when this is the case many hives severely suffer by their depredations. When once wasps in any number have gained an entrance into a hive, the bees can seldom eject them,'and the invaders generally remain until they have freely regaled themselves from the luscious store. They not only consume the honey, but cause a good deal of worry to the legitimate inhabitants of the hive, as well as killing the foremost defenders of it. Wasps being much superior in strength, it requires at least three bees to master one of them.

Having suffered loss in our own apiary from the attacks of wasps, we feel it desirable to give a detailed account of our troubles from that cause. An Italian stock was besieged and worried by wasps to such an extent that in September the bees deserted it in a body. Fortunately it happened that they chose a time for their departure just as we visited the apiary. An unusual turmoil was heard in the hive, such as is experienced at the time of swarming, and on immediately examining the entrance we observed that the bees were quitting in tumultuous haste. The usual methods that induce bees to settle were tried-amongst others that of throwing 
sand up into the air, so that it should fall down amongst the bees on the wing; but they were dispersed in disorder, and their flight extended over three adjacent gardens. We only discovered the clustered bees by diligent search, as the sequel will show. Permission being asked of our next-door neighbour, we searched his garden to see if our bees had alighted there; but found that they had passed over. Making a similar application to the owner of the garden adjoining, we entered, having a straw hive in hand, but no bees were there. After looking diligently all round, and climbing the wall, thereby gaining a view of the third garden, we perceived in it unmistakable signs of an unwonted commotion. The occupiers of the house were intently looking at a particular part of the garden, and there was a dust-pan and a key, with which the master had been "tanging the bees," to induce them to settle. We quickly made for the proper entrance to the garden, and soon discovered our little wanderers clustered to a large flower-vase. After brushing them into the hive, and leaving it propped up with a stick, in order that the stray ones might join, we returned home for an hour or so, to give them time to settle. Judge of our vexation when, on returning to fetch the hive home, we found that the refractory creatures had again taken flight, and that all the work was to do over again. The wasps were not to blame for this second flight of the Italians; we judged that the swarm had been disturbed by visits from a 
colony of bees that we discovered were living the life of outlaws under the roof of an adjoining house. Although much disheartened and perplexed, we at once renewed our search, and, upon enquiry, found that the missing bees had taken a southerly course across the turnpike road, and it was therefore necessary to ask permission to search the gardens of the houses opposite. From one of these we observed, on looking through the hedge, that the inhabitants of the next house were on the qui vive. On enquiring whether they had seen a colony of bees, the wary old dame replied that she "had no bees but her own," but added that "they were very" much excited." Having asked permission to go through the hedge to look at her bees, we soon discovered our Italians on the top of the old lady's bee-house. There was no difficulty in identifying our own bees; their yellow rings were as good as a private mark. Quickly hiving the swarm, we took them home, and replaced them in the hive they had quitted. It was almost destitute of honey; but by liberal feeding, and lessening the entrance so that only one bee at a time could find ingress or egress; we succeeded in inducing them to rest in their old home. Thus nearly half a day's exertion was needed to save a fine colony, which would otherwise have been utterly lost by the power of the relentless wasps.

Much watchfulness is needed to prevent the loss of swarms, and the foregoing incident may serve to suggest the necessity of having hives so located as to be con- 
stantly within view, either from the dining-room, or of those whose duties oblige them to be near the apiary. If we had not happened to be at hand at the moment this colony started, it would have been irretrievably lost to us, as is the case with many swarms and colonies simply because the departure takes place without any one to witness.

In the season of $186_{5}$ wasps were as few as they were numerous the preceding year; their paucity was attributable either to frosts in May or to heavy rains in June, which destroyed them in their nests. In general wasps are great depredators of wall-fruit, but in the autumn before mentioned the bees occupied the wasps' foragingground. Perhaps never in the memory of bee-keepers did bees feast upon fruit in the same manner. Various reasons have been assigned for this unusual occurrence ; some thought that as there were so few wasps the bees were unmolested, and enjoyed the saccharine matter in the fruit without let or hindrance-for bees are about as partial to the company of wasps as mice are to that of rats. Other bee-keepers remarked the sudden and early termination of the honey-gathering, and conjectured that the bees, being anxious to make up their winter store, endeavoured to bring home nectar from the fruit because the weather was unusually fine. There was one feature which is worth remarking: as far as our observation extended, the bees did not, like the wasps, break the skin of sound fruit, but were satisfied with lapping the juice of the ripe fruit that had the skin already broken. 
There are some birds that are given to preying around beehives, and if their visits become too systematically troublesome, it may be worth while to take active measures for making their presence scarce in order to prevent these devourers from taking up a position near the alighting-board and pouncing upon each bee as it makes its exit. The toad is a less formidable enemy, but if one of these creatures is found beneath a hive-stand it may fairly be concluded that he is on the watch for such bees as may drop to the ground under their loads. Mice, again, will make their abode in a hive for the winter, and devour the stores when the bees are too inactive to interfere. Spiders, ants, and other insects will also have to be guarded against.

Other formidable enemies of bees are moths. These insects are creatures of the night, as the wasps are of the day, and they make their way into the hives under cover of darkness, in spite of the bee sentinels. They deposit their eggs in any crevices in or near the hive that they can find. There the warmth of the hive, or of the sheltered situation, causes the eggs speedily to hatch, and then the maggots soon work their way to the comb and larvæ food, which they greedily devour, thereby often bringing about the gradual but certain destruction of the whole community of bees. The best method of keeping moths outside the hives is to lessen the entrance, as before alluded to. Also, in the early spring, the hives should be lifted from their floor-boards, which must then be made thoroughly clean; and all crevices and corners 
about the hive and stand should be scraped, so as to get rid of all eggs of moths and other insects before the warm weather hatches them or enables them to do mischief. The bee-moth is not so troublesome in Erigland as it is in America and some parts of Germany; but still its encroachments should be carefully guarded against in this country, for if not it may easily increase to a very serious extent.

\section{§ XI. BEE-KEEPING IN LONDON.}

There are many persons, now in this noisy city pent, who frequently remember the days of childhood when, among pastures of clover or amidst flowery heath and woodlands, they listened to the cheerful hum of bees. Partly from a desire to revive these old associations, and also from a natural liking for the tendance of living creatures, such persons would be glad to keep bees if they thought it possible to do so in London or its suburbs with any chance of success. We do not wonder that many should doubt even the possibility of bees feeding themselves amidst such an "endless meal of brick ;" but we can easily prove that bees, if not placed too near to smoky chimneys, are able to produce honey, both for themselves and for their masters. To make this plain we will mention some special instances of metropolitan bee-keeping.

About a century ago a Mr. Wildman kept a beehouse and honey warehouse in Holborn, near to where 
Middle Row lately stood. He was not only a tradesman, but was also the apiarian of his day. He kept hives of thriving bees on the roof of his house in Holborn, and many of the nobility and gentry used to mount thither in order to inspect the apiary. At that period St. Pancras was a "village two miles north-west of London," and what is now the Regent's Park was open country. It was then much easier for London bees to find their favourite forage, but Mr. Wildman believed that his hives were filled with stores from a considerable distance. Whilst enjoying his country rambles on Hampstead Heath, he had a shrewd suspicion that many of the bees he there observed gathering honey were labourers from his own apiary. In order to identify his own flock amongst the rest he hit upon a homely but very effective expedient. Having borrowed Mrs. Wildman's "dredging box," he stationed himself near the entrance of his hives, and gently dusted his bees with flour as they issued forth. He then betook himself to Hampstead, where he found his previous surmise confirmed, for there were numbers of his bees in their livery of white.

Wildman became noted for the remarkable control he obtained over his bees, many instances of which he exhibited before the public. Several of his operations with them were regarded as feats of legerdemain by the uninitiated, as when he appeared before King George III., with a swarm of bees hanging in festoons from his chin, or suspended in a cluster at arms' length. The Fournal 
of Horticulture recently, in alluding to Wildman, gives the following particulars as to his performances :-

"Near the 'Three Hats,' Islington, was a place of popular entertainment called 'Dobney's Tea Gardens,' kept by Mrs. Ann Dobney. These gardens occupied the ground between White Lion Street and Winchester Place, and were established as far back as I728. In I77I the house was taken for a short time as a boarding school; but it was soon changed to its original purpose as a place of amusement, for in 1772 Daniel Wildman exhibited bees here. This is a copy of the advertisement :-

"June 20, 1772. Exhibition of bees on horseback! at the Jubilee Gardens, Islington (late Dobney's), this and every evening, until further notice (wet evenings excepted).

" The celebrated Daniel Wildman will exhibit several new and amazing experiments, never attempted by any man in this or any other kingdom before. The rider standing upright, one foot on the saddle and one on the neck, with a mask of bees on his head and face. He also rides standing upright on the saddle with the bridle in his mouth, and, by firing a pistol, makes one part of the bees march over the table, and the other swarm in the air and return to their hive again, with other performances too tedious to insert. The doors open at six ; to begin at a quarter before seven. Admittance-Box and gallery, 2s.; the other seats, Is." "

The secret of Wildman's skilful manipulation is well understood now; it consisted in a-careful holding and disposal of the queen, together with confidence in the generally inoffensive disposition of bees. Dr. Evans, whom we have often quoted for his correct information in apiarian matters, thus speaks of his feats :-

"Such was the spell which round a Wildman's arm

Twined in dark wreaths the fascinated swarm, 
Bright o'er his breast the glittering legions led,

Or with a living garland bound his head.

His dextrous hand, with firm, yet hurtless hold, Could seize the chief, known by her scales of gold,

Amidst the wondering train prune her thin wing,

Or o'er her folds the silken fetter fling."

To recur to our subject. After the days of Wildman our own establishment in Holborn became widely known for beehives and honey. Although we never attempted to start a London apiary at all approaching in extent that of our predecessor, we have occasionally kept bees on the house-top, both in Holborn and Regent Street. At each of those situations we have noticed that the bees bring pollen as well as honey into their hives. One summer there was brought under our notice an illustration of the acuteness of the scent of bees and of their diligent search for food, proving, too, that if sweets can be obtained, even from unusual sources, the bees will find them out. A poor woman, who, at the corner of an adjacent street, vends "brandy balls," "toffee," "rock," and other saccharine compounds-all well known to most juveniles-used to receive frequent visits from our bees. Their visits to the old dame's domain were at first rather interesting, and if the few pioneers who had the sagacity to find such a store had kept the secret only to themselves, their company would not have been objected to. Such selfish policy does not, however, accord with the social instinct of bees, and these soon informed their companions of the good fortune provided for them in an 
archipelago of sugar islands. - Day by day the swarms of these uninvited visitors increased, until all legitimate customers were beaten off; and the old dame had to see, not only her hope of gain destroyed, but her stock of "goodies" sensibly diminishing by the thefts of these brigands of the air. She could not, or dared not attempt to, drive the intruders away, so made diligent enquiry as to where the robbers were harboured. Having traced them to our establishment in Regent Street, she came to implore of us to move the bees if possible, or she would have to move her stall, and so lose her "connection" in the "toffee" and "rock" trade. Wishing not to hinder the poor woman in gaining her livelihood, we decided on removing our bees into the country.

Another special instance of bees being profitably kept in proximity to the busy thoroughfares of London is now before us. Two years ago we supplied a stock of English bees to a gentleman residing in the Strand, the back windows of whose house open on the Thames Embankment and the river. Thus the bees have a fine open flight, as their hive is placed against the sash on a third floor (an opening is cut to match the entrance, so that the bees have a covered way to their hive); from this they are seen taking their flight across the river Thames, to what may be thought the unattractive locality of Lambeth. However, they seem to reach some "green fie'ds and pastures new," probably in the gardens of the archbishop's palace, for they return laden with pollen 
from flowers, and during the two summers that the hive has been so located, have yielded nice glasses of honeycomb as well as afforded a considerable amount of pleasure to the owner and his friends, with every prospect of going on flourishing.

It is difficult to assign an exact limit to the distance that bees will go in search of honey-yielding blossoms. It has been proved by various experiments that they will fly, say, five or six miles, if the supplies are scanty within a shorter radius; but bees well understand that first 'of all economies, the saving of time, and if they can find forage near at hand they prefer it. Hence, other things being equal, the quantity of honey stored will be in proportion to the contiguity of good pasturage. In this way it is that the systematic removal of hives, as practised in many districts, has such a notable effect on the honey harvest.

A novel sight for Londoners to witness occurred in June 1865. A swarm, having been ordered to be sent into the country the following morning, was temporarily placed on the leads at the back of our house, r 49, Regent Street. The sun shining hot on the hive, or some other cause, induced the inmates to decamp. After a time a passer-by called in to inform us that some bees had arrested the progress of a cab. We at once conjectured that they were our missing swarm, the absence of which had previously puzzled us not a little; so we sent our man with a straw hive to bring the truants back, which 
he succeeded in doing, followed to the door by a crowd, who were amazed at the sight of the "'oney-bees," as the Cockney lads called them. Cabby had to be compensated for the loss of his fare, for the affrighted passengers had left him in a hurry, so that, altogether, no little commotion was caused-a crowd so soon collects in London streets.

During several years we kept bees in the Zoological Gardens, Regent's Park, and have there frequently taken full and handsome glasses of honey. The position of our apiary was on the site now occupied by the new monkey house. The visitors to the gardens found considerable interest in watching the bees in our glass hives, and were afterwards much disappointed at the absence of so entertaining an exhibition. The writer had the honour of showing and explaining the working of these hives to some of the juvenile members of our Royal Family who had come to the gardens on one of their accustomed early morning visits with their French governess. Their conversation was in French; and on entering the bee-room, "Regardez les abeilles! Voyez donc la reine!" was soon on their lips. The young princesses took special care that their brother Arthur, as they affectionately called him (now known by the title of H.R.H. the Duke of Connaught), should observe the attention paid by the working bees to their queen, as well as to other points of interest connected with the busy scene before them, with which they all expressed themselves much delighted. A collection 
of these hives were also exhibited by the Acclimatisation Society of Great Britain, with living bees in them, at the Fish Department of the Royal Horticultural Gardens, South Kensington, and prospered satisfactorily until removed, the space being required for other objects.

A gentleman residing in St. James's Place has, for some considerable time past, kept bees in his garden there. He uses our improved cottage hives, and his bee-keeping is decidedly successful, as he generally takes some fine glasses of honey each season, besides leaving sufficient as winter store for the bees. For a London situation, St. James's Place is a very favourable one; the gardens behind the houses pleasantly face the Green Park, so that the bees have an uninterrupted flight to start with. They are also within easy range of the richly flowered gardens of Buckingham Palace and those of the nobility and gentry who reside around the Parks. To those gardens the bees of St. James's Place resort, without waiting for any licence or certificate from the royal and noble owners of the honey-yielding preserves. Being within a short distance of our establishment, when this gentleman's bees swarm he generally sends to us for assistance in hiving them.

The neighbourhood of St. John's Wood, and, indeed, almost all the suburbs of London, are favourable for the production of honey. We mention St. John's Wood because, from the fact of having kept bees there ourselves, we are able to prove by experience that they do 
well in that locality. We know of several bee-keepers on nearly all sides of the town who have each had a considerable surplus of honey in their supers, after leaving sufficient for the bees themselves in the lower or stock hive:. Whilst referring to this part of the environs of the metropolis we take the opportunity of explaining that our own apiary (a coloured view of which forms the frontispiece of this work) is situated near Hampstead. The spot is not so easy of access as might be desired, being somewhat remote from the road, in a portion of a meadow between West End and Kilburn.

On looking at the picture, it will be seen that there are a large number of hives on separate stands, mostly barframe hives, at some little distance from each other, in order to prevent confusion when manipulating. At the back, near the hedge we have some hives on rails, which like the others are well protected from the weather, every one having its own covering. Besides these there are tluree bee-houses, which are so suitable for preserving from the weather hives with fixed combs, and where there is less need for manipulation, such as our straw cottage hives. One house will contain six hives, another three, and a third two. These houses are ex. plained at page $\mathbf{6} 66$.

At the back, about the centre of the drawing, is the operating house, also forming a storehouse or magazine where apiarian appendages are kept, together with feeding syrup and combs, etc., so essential for use, and which yet must 
be secured from the thievish propensities of the bees, and access to which, if possible to gain, demoralises them so much that they make war and attempt to pillage each other's hives, as elsewhere referred to.

The shallow pans in front (earthen milk pans) have water in them, and are so placed that the bees may have access to moisture, which is so essential for them in spring for comb-building and breeding. Straight straws are floated on the water so as to admit of the bees imbibing without the liability of their being drowned.

On this ground we largely cultivate Italian bees, and unite imported queens to colonies of English bees, to be ready to supply swarms and stocks therefrom as pure and genuine as possible.

The district is not so good for bees as if it were farther in the country and more removed from London smoke; nevertheless we have had fine supers worked here, and find it a great convenience to have a bee-farm at so moderate a distance from town to carry on this department of our trade.

Some time ago we exhibited in our window a super of fine honey from the apiary of Mr. Shirley Hibberd, the proprietor and editor of the Gardener's Weekly Magazine. It consisted of a box containing twenty pounds nett weight of honey, and was produced at Stoke Newington, only three and a quarter miles from the General Post Office.

The Times "Bee-Master," whose letters from Tun- 
bridge Wells awakened so much interest in this pleasing pursuit, also commissioned us to exhibit a super produced under his own management in that locality. Mr. S. B. Fox, at Exeter, had upwards of four hundred pounds of honey, of excellent quality, though one of his apiaries is quite within the city.

\section{§ XII. GENERAL REMARKS.}

\section{BOOK-KEEPING.}

Every bee-keeper should be a book-keeper, that is so far as to have a permanent record of the events of the apiary and the fortunes of his bees. A book similar to a tradesman's journal would be very suitable for the purpose. In it he should note down the date of the first swarm of the season especially, and those of other swarms also; and in autumn the quantity of honey taken from each hive should be entered, with remarks on the probable size and weight of the various stocks. These particulars will not only be interesting for the bee-keeper to turn to in winter, but will be of practical service in enabiing him to know the exact age and probable strength of each stock. The bee-book may also be contrived to show the total amount of honey that the bees have produced for their owner, and the nett profits of the apiary. A simple and clear account like this-provided, by the bye, that it does show a satisfactory balance-will be very useful for inducing cottagers and farm-labourers to start bee-keeping. Nothing like ocular demonstration for this class. 
The "humane" apiarian will reason with them in vain until he shows them a monster skep of honey and mentions the price that it will fetch in the market. When convinced that the depriving system will pay, the cottager will gladly adopt it.

\section{ADVICE FOR COTTAGERs, ETC.}

A writer in the Quarterly Review (whose article has since been published by Mr. Murray as a shilling handbook, "The Honey Bee") gives the following good advice: "Don't bore the cottager with long lectures; don't heap upon him many little books; but give him a hive of the best construction, show him the management, and then buy his honey; buy all he brings, even though you should have to give the surplus to some gardenless widow. But only buy such as comes from an improved hive-and you cannot easily be deceived in this-one which preserves the bees and betters the honey. Then, when you pay him, you may read to him, if you will, the wise rules of old Butler, exempli gratia :-

" 'If thou wilt have the favour of thy bees that they sting thee not, thou must not be unchaste or uncleanly; thou must not come among them with a stinking breath, cansed either through eating of leeks, onions, or garlic, or by any other means, the noisomeness whereof is corrected by a cup of beer; thou must not be given to surfeiting or drunkenness; thou must not come puffing or blowing unto them, neither hastily stir among them, nor violently defend thyself when they seem to threaten thee ; but, softly moving by, thy hand before thy face, gently put them by ; and, lastly, thou must be no stranger to them. In a word (or rather in five words), be chaste, 
sweet, sober, quiet, familiar; so they will love thee and know thee from all others." "

These "wise rules of old Butler" are, however, in the main taken from Columella.

Allusion having been made to the profit that may be gained by the judicious management of bees, we will illustrate that point by relating an anecdote of a certain French curé.* It is one which may be suggestive to some of the rural clergy in this country, who might almost as easily keep an apiary as they do a garden or an orchard.

A good French bishop, in paying his annual visit to his clergy, was very much afflicted by the representations they made to him of their extreme poverty, which, indeed, the appearance of their houses and families corroborated. Deploring the sad state of things which had reduced them to such a condition, he arrived at the house of a curate, who, living amongst a poorer set of parishioners than any he had yet visited, would, he feared, be in a still more woful plight than the rest. Contrary, however, to his expectations, he found the appearance of this remote parsonage to be superior to those he had already visited.

* This story, in a disguised form, or, as the writer would say, an improved form, was quoted in the Cornhill Magazine some time ago. In transforming the bee-keeping curé into an English clergyman the effect was cleverly enhanced, especially as to the dismay of the decorous English prelate in hearing that his poor brother in the Church had turned "manufacturer;" but then the araisemblance of the story, as we have it, was destroyed. 
Everything about the house wore the aspect of comfort and plenty. The good bishop was amazed. "How is this, my friend?" said he ; "you are the first pastor I have met with having a cheerful face and a plentiful board! Have you any income independent of your cure?" "Yes, sire," said the pastor, "I have: my family would starve on the pittance I receive from the poor people that $I$ instruct. If you will walk into the garden, I will show you the stock that yields me such excellent interest." On going into the garden he showed the bishop a long range of beehives. "There," said he, " is the bank from which I draw an annual dividend, and it is one that never stops payment." His harvest of honey enabled him almost to dispense with the use of sugar, leaving him a considerable quantity for disposal in the market; of the coarser portions he made a tolerable substitute for wine, and the sale of the wax nearly paid his shoemaker's bill. Ever afterwards, when any of the clergy complained to the bishop of poverty, he would say to them, "Keep bees! keep bees!" In this succinct advice-extending it to laity as well as clergy in rural districts-we heartily join, believing that in this country a tenfold greater number of hives might be successfully kept than are now established.

In a very practical sense the oft-repeated lines of Gray are strictly true :-

"Full many a flower is born to blush unseen, And roaste its sweetness on the desert air." 
An apiary in the garden of every village clergyman would afford the means of economising this unclaimed bounty of Providence.

\section{An Old Anecdote.}

An amusing instance of the fondness of bears for honey is related by a Muscovite ambassador to Rome, in the "Feminine Monarchie; written out of Fxperience by Charles Butler. Printed in the Year I609"-a quaint, but sensible work :-

"A neighbour of mine (saith he), in searching in the woods for honey, slipped down into a great hollow tree, and there sunk into a lake of honey up to the breast; where-when he had stuck fast two days, calling and crying out in vain for help, because nobody in the meanwhile came nigh that solitary place-at length, when he was out of all hope of life, he was strangely delivered by the means of a great bear, which, coming thither about the same business that he did, and smelling the honey, stirred with his striving, clambered up to the top of the tree, and then began to lower himself down backwards into it. The man bethinking himself, and knowing that the worst was but death-which in that place he was sure of -beclipt the bear fast with both his hands about the loins, and withal made an outcry as loud as he could. The bear being thus suddenly affrighted, what with the handling and what with the noise, made up again with all speed possible. The man held, and the bear pulled, until, with main force, he had drawn him out of the mire; and then being let go, away he trots, more afeared than hurt, leaving the smeared swain in joyful fear."

\section{INSTRUCtions for New BeE-KeEpers.}

Bees may be very inexpensively and profitably kept in the cottager's hive (see page I Io), which will be found a very productive one. It is true that it has not the appliances of windows and bell glasses; for the cottager 
is not supposed so much to care for his hives as a source of amusement; his object in bee-keeping is simply the profit it may bring. For those of our readers who wish to have united the facility of observing the bees with that of the plentiful production of honey, we would especially recommend the improved cottager's hive, described at page I I2. If inclined to go to a little further expense, the hives described at pages I 1 3, I20, I39, and I43, all afford constant opportunity for inspection of the bees, and allow of their working freely in the most natural manner. The Stewarton hive (page 146) is also a favourite with those who give the preference to honey stored in boxes, although the opportunities for observation are not so great as with some others.

Renfrewshire BeE-Kegper's Hints on Supering AND Prevention of Swarming.

The mention again of the Stewarton hive affords us an opportunity of which we avail ourselves to put before our readers an extract from a private letter received whilst the foregoing pages are in type, from that successful and accomplished apiarian already alluded to, "The Renfrewshire Bee-keeper,"which seems to us to contain a useful hint or two as regards putting on supers and the prevention of swarming, which, although practised with our friend's $f a$ vourite hive, can be advantageously adopted with other hives. He says, "In working Stewarton colonies, I am seldom troubled with swarms, the secret being, in giving super 
space at the nick of time, before swarming mania seizes them; and when once they have taken to supers, I keep an ample supply of space in advance of their wants.

"However hot the weather may become, they somehow retire upstairs to this vacant room, and comb-building there affords them employment, and they do not readily think of swarming. For instance, in the beginning of summer last year (1 876 ), the season was so bad that at first I gave them little room; suddenly the weather became hot and favourable, and one strong colony swarmed right off. I excised the royal cells-and returned the bees; no useoff they came again in eight or ten days' time; took the hive to pieces, cut out all royal cells, and in addition, the thought having occurred to me that maturing drone brood was an accessory to swarming condition, I excised every portion of that also. With seven supers (each four inches deep) they rested content and kept to work most vigorously, never attempting to swarm again."

From this extract the practical bee-keeper may learn much; particularly as regards depriving the bees of the inclination to swarm by cutting away the drone brood.

Perhaps we may here be allowed to advise the filling tip of vacancies where excision of drone comb is made (whether with brood or without), by the insertion of clean worker comb, in order to prevent the construction of the former. 


\section{BeEs Working in Supers.}

There is a little matter here with regard to bees working in supers that should be noticed, and that is that when the ascending hole is round and in the centre of the stock hives, the bees sometimes start wrong and carry the comb upwards. This has two objections: the first is that the bees do not work so quickly as when they begin from the roof of the super, and the other is that the queen gains an easy ascent and deposits eggs in cells where honey is wanted. When this style of comb-building is observed, it is best to take the super off, cut the comb down, and endeavour to make it adhere to the crown of the super by using a little nielted wax (page $26 \mathrm{I}$, or if a glass, as recommended at page 262 ), so that the bees may continue the work, as is their wont, downwards.

There are few hobbies which cost so little outlay as the keeping of bees. Once the "plant" of hives is purchased, there is little, if any, additional expense, and always a probability of a fair return. If honey be obtainable the bees will find it; they work for nothing, and provide themselves with sustenance, requiring only a very little labour from their keepers; and that labour of a pleasing and instructive kind.

To the advanced and skilful apiarian we would - especially commend the use of the frame hives. With these, as we have attempted to show, the bee-keeper has a full command over his hives and bees. Many 
mistakes, it is true, have been made by uninitiated beekeepers in using the more elaborate hives. Being struck with the remarkable facilities afforded by these superior hives for the extraction of any one comb, and, perhaps, fascinated with their easy sway over so highly organised a community, these new-fangled bee-keepers have acquired a habit of perpetually and incautiously meddling with the bees. The inevitable results in such cases are, distress to the bees, impoverishment of the stocks, and loss and vexation to the over-zealous apiarian. All these things may be avoided if it is remembered that there are first steps in bee-keeping, as well as in chemistry, croquet, or cricket. In bee-keeping, as in floriculture, it is a great point to know when to "let well alone." There is no florist, however anxious for a prize, who would be continually pulling up his plants to see how their roots were growing. Doubtless the full control which the bars and frames afford over the inmost recesses of the hives is a great temptation to the bee-keeper; but if he yields too readily to it he will imperil his chance of profit and deprive himself of that continuous source of interest which a judicious apiarian always enjoys.

\section{Ignorance Concerning BeEs.}

Many persons who are well-informed on most subjects are profoundly ignorant on all points of the natural history of bees; and as with old so with young. As an amusing illustration of this, we may transcribe an order 
we received a few years back from a seminary in the north of Fngland: "Master — presents his compliments to Messrs. Neighbour, and begs they will send him a swarm of bees; he encloses six postage stamps, and hopes they will send him a good swarm." This embryo naturalist was evidently of a mercantile turn, and had a mind to buy in the cheapest market, for in a postscript he adds : "Please let it be fourpence, if you can!" We need scarcely say that, in reply, we endeavoured to enlighten our juvenile correspondent as to what constituted a swarm of bees, and returned the stamps, with our thanks.

\section{Superstition Respecting Bees.}

Much superstition has existed, and, in some quarters, still exists, among the poor respecting bees. If a death occurs in the family of the bee-owner, these superstitious folk consider it needful to make the bees aware of the bereavement by "waking" them; that is, by giving a few raps at the entrance, and audibly announcing the circumstance. If this be not done, "no luck," say they, will come of the bees the following season. One summer, even near the metropolis, we heard a cottager bemoaning to his neighbour "his bad luck with his bees," when the other replied, "Ah! no wonder; you never 'waked' your bees when your wife died; what can you expect if you omit such needful duty?" In many parts of France, as well as here, it is a custom on such occasions to put the bees into mourning, by placing 
black crape or some such material round the hives. Bees also receive intelligence when a marriage or a christening takes place: in these cases the hives are draped with red cloth. In fact it is considered an essential element of "good luck" to inform the bees of any remarkable circumstance that occurs in the family of the bee-keeper. How would these good people manage with the newly imported foreign bees, for they can hardly be expected to have learned our "lingo"? This difficulty is, however, not likely to be experienced, for the keeping of superior sorts implies an intelligence that would be above any such pitiable nonsense. Fancy a man in this nineteenth century haranguing his bees after the above-mentioned fashion! Mr. Langstroth says that "some superstitious folk in America assert that the bees sometimes take the loss of their master so much to heart as to alight upon the coffin whenever it is exposed." A clergyman told him that he attended a funeral where, as soon as the coffin was brought from the house, the bees gathered on it so much as to excite alarm. Some years after this occurrence, being engaged in varnishing a table, the bees alighted upon it in such numbers as to convince the clergyman that love of the varnish on the outside, rather than any respect for the deceased within, was the occasion of their conduct at the funeral. $\mathrm{Mr}$. Langstroth adds: "How many superstitions, believed even by intelligent persons, might be as easily explained, 
if it were possible to ascertain as fully all the facts connected with them!" Only a short time since an English' clergyman informed us of a severe contest going on in his garden between Church and Dissent, for he had a hive of bees from a Nonconformist in his parish, and these dissenting bees persistently attacked his hives to such an extent that he really must get rid of them, and thus liberate his episcopal apiary from such discordant disturbers of the peace.* Another infatuation is, that you should on no account part with your bees for silier. money-only for gold. This is so far sensible that it ensures a respectable price. Certain credulous beekeepers cannot, on any account, be induced to part with their bees for money; they will barter, but not sell - to sell bees is, in their view, to lay themselves open to evil fortune. If these apprehensions are correct, our punishment will be a severe one, for we have been great offenders in that way, and seem likely to go on sinning.

The culture of bees would be greatly promoted if a knowledge of it were considered necessary as one of the regular qualifications of a gardener. So little time is needed to gain the skill requisite for the tendance of an apiary, that it seems only reasonable to expect it of awell-taught gardener, and he should feel a pleasure in the circumstance of its forming a part of his duties. In

* The explanation may probably be that a strong hive was brought close to weak or queenless ones. 


\section{MISCELLANEOUS INFORMATION. [CH. VI.}

Germany, where a country gentleman's table is kept constantly supplied with fresh honey, the gardeners are expected to understand the management of hives; and in Bavaria modern bee-culture is taught in the colleges to all the horticultural students. Travellers in Switzerland will call to mind the almost invariable practice of placing new honey on the breakfast tables at hotels in that country. We are told that some of this new honey so highly approved of is only golden syrup with a portion of the colour extracted, and possibly otherwise made up to be palatable; also that there is a factory in Switzerland doing a profitable business in this way. If such be the case, tourists are often taken in. Treacle will do no one any harm, but it is not pleasant to be gulled except for the reason that "ignorance is bliss."

\section{Caution Respecting Flighe Hole.}

Fine colonies are sometimes destroyed by the entranceway becoming stopped by some impediment or other, and care is requisite to keep a watch, that so fatal a catastrophe does not happen, because the bees (unless. where iery ample ventilation is given), excited by their imprisonment, make matters worse, by raising the temperature of their hive to such a pitch that the combs melt from their foundations, and the bees themselves are suffocated, presenting, alas! a most woful spectacle to witness.

We give this hint because of having ourselves suffered 
from a similar cause when workmen have been employed in the vicinity of hives; these gentlemen, thoughtless of the welfare of the bees, but most careful of their own convenience, have placed a piece of wood across, or otherwise stopped the entrances, to prevent the bees coming out. In summer weather a very short time of confinement in a close hive suffices to complete the work of desolation; but should the bee-keeper's attention be drawn to such a state of things, he must immediately raise the hive from the floor-board and let the poor bees. have all the air possible, leaving them thus exposed for the purpose of affording them a chance of revival. When bees are likely to incommode those whose duties temporarily oblige them to be near the entrances, it is better to cover the hive over night with net in the form of an inverted bag tied at the base, so that the bees may be able to get air within the net and not be too closely confined. The objection to this is that you stop all labour, which of course harasses the bees for the time, Dut there will be no other bad results. The foregoing remarks more particularly apply to the summer season. In winter or in the spring, when the weather is cool and the bees are not so numerous, hives may be shut up even for a day or so without much ven. tilation, and but little harm will arise therefrom.

Hive for Swarming NeEdful.

There is another little matter of detail that should be 
named here; that is, the necessity of the bee-keeper always having a common hive in readiness near the bees, so as to be able to secure any swarm which may unexpectedly start.

\section{CONCLUSION.}

Here our pleasant task must close. We trust that all information has been given that is needful to enable the practical bee-keeper to begin business and the scientific apiarian to extend his observations. In conclusion, we would remind all bee-keepers who earnestly desire success, and who hope to draw pecuniary profit from their pursuit, of the golden rule in bee-keeping- "Keep your stocks strong." In exercising the assiduous attention and persevering effort which that maxim enjoins, they will not only be regarded as bee-keepers, but, as Mr. Langstroth says, will acquire a right to the title of bee-masters. 


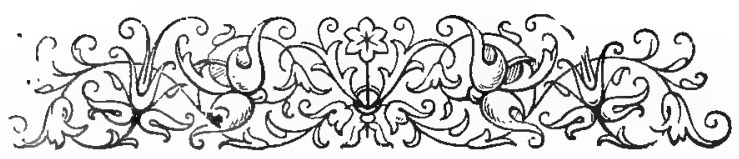

\section{APPENDIX.}

\section{BEES AT THE EXHIBITION OF 1862.}

The annexed figure represents our stand in the Agricultural Department of the International Exhibition of I862. The space granted us in the World's Great Fair was somewhat limited; but we were able to exhibit a tolerably complete stock of apiarian apparatus, and all the more important beehives. Amongst these was a unicomb hive stocked with Italian bees. This was an object of great attention, and daily hundreds of visitors flocked round our stand in order to watch the movements of the Italian queen with her gay and busy subjects. The entrance-way for the bees being in the "Open Court," to which all visitors had access, it was necessary to place the hive in'an elevated position, so that it should be beyond the reach of incautions passers-by, and to obviate any chance of annoyance to the vast crowds of people continually around. 


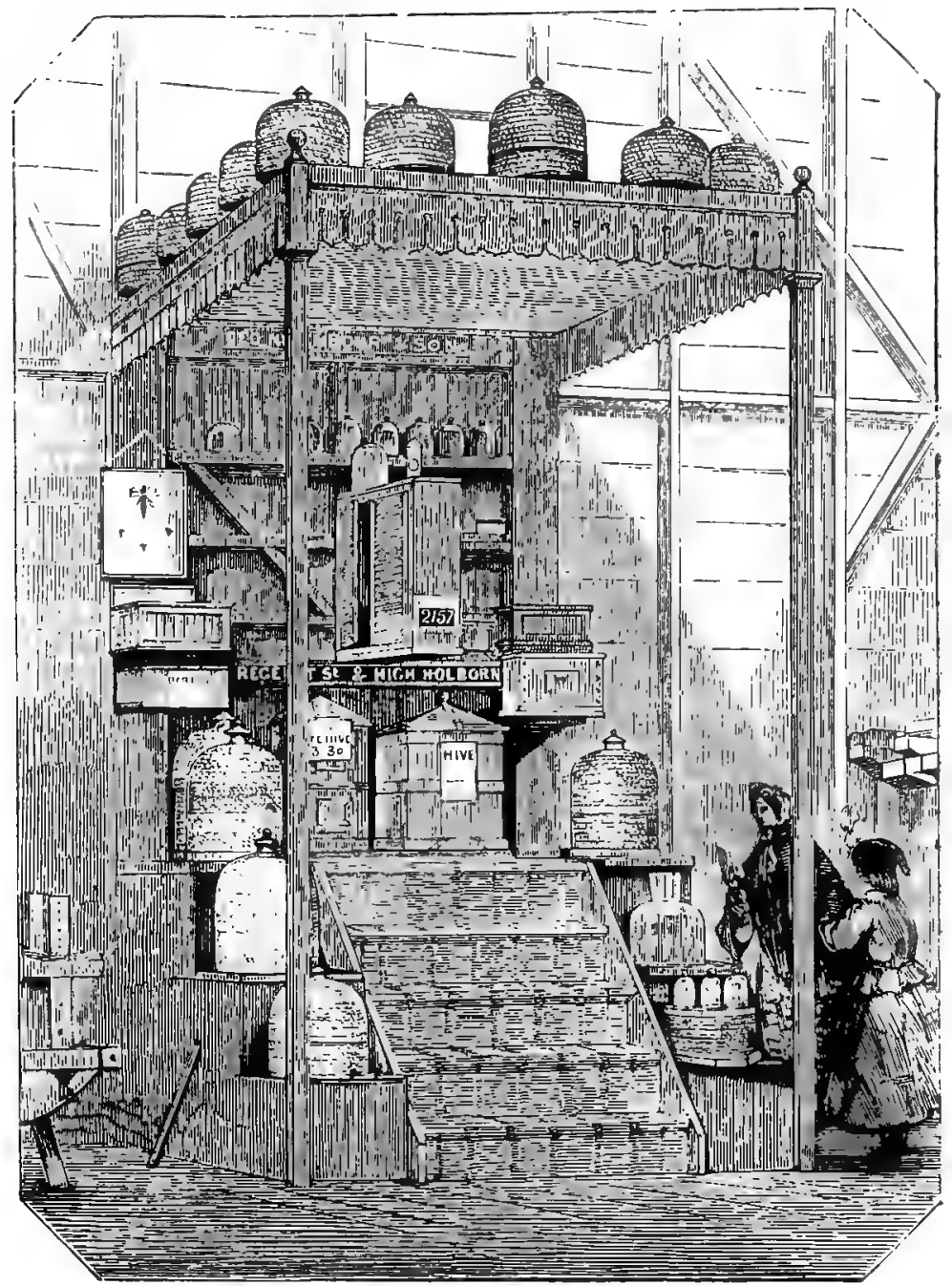

STAND AT THE EXHIBITION OF 1862. 


\section{CASES OF ACCLIMATISING BEES.}

Among others who took a deep interest in the exhibition just described was Mr. Edward Wilson, President of the Acclimatisation Society of Victoria. This gentleman requested us to pack four stocks of the Italian bees for conveyance to Melbourne. With the assistance of Mr. Woodbury - whose aid was, indeed, essentialthese stocks were sent off on the $25^{\text {th }}$ of September, I862, by the steamship "Alhambra," so as to arrive at the colony during the Austral summer. The hives were Woodbury frame-hives, having ample space and ventilation, as well as the means of supplying water to their inmates during the voyage; there was also a sufficient store of honey to last until the following March. The bees arrived at Melbourne, where they were released after an imprisonment of seventy-nine days, and have since rapidly multiplied, the climate and pasturage of Australia greatly favouring the increase of this superior variety of the bee.

Mr. Wilson was so well pleased with the careful manner in which these stocks were fitted out for their voyage across the seas, that he subsequently instructed us to prepare him three more hives, which were sent out in a sailing vessel. Owing to the mismanagement of the water supply during the voyage, only one stock survived in this instance. Mr. Wilson informs us that one of these hives contained 136lb. of honey on the $25^{\text {th }}$ of December, r864 (Midsummer in Australia).

Upwards of twenty years ago we sent a Nutt's hive stocked with bees to New Zealand. We then adopted the plan of fixing the hive in a meat safe, so that the bees could fly about a little, and also cleanse the hive of their dead, they being always very attentive to sanitary arrangements.

Several more recent exportations of Italian bees have been made by us. We have sent two stocks to Madras, which arrived safely, and we hear are doing well, also a stock to South Africa under the 
care of the lady who ordered them, and who was herself going out. We had the satisfaction of receiving the following note:-

"Grahamstown, Nov. 3, 1875.

"Mrs. Mullens is very pleased to inform Messrs. Neighbour and Sons that the stock of Ligurian bees supplied to her on board the 'Nyanza' at Southampton on July 23 rd have arrived quite safely. Mrs. Mullens thinks they were exceedingly well packed; they had a trying journey by bullock waggon two days after leaving the sea. They were released from the hive on September 3 rd, and appeared

- weak at first, but began to work in less than an hour. A large number of dead bees were found at the bottom of the hive on opening-most likely caused by the boat in which the bees were baving water in it."

This report we consider very favourable. There would naturally be a great mortality during such long confinement, and for the reasons also which Mrs. Mullens mentions.

\section{PHILADELPHIA EXIIIBITION OF 1876.}

Dated Dec. $12 t h$.

Award of Prize Medal to G. Nejghbour and Sons,

For a large and varied collection of economical beehives so arranged that the honey can be taken without the destruction of the bees. Special altention is directed to the Unicomb Hives with venetian blinds to allow the bees to be exposed to light, whilst the sun's rays are excluded. Also to a Honey Extractor by centrifugal force, which removes the honey from the combs without injuring the Iatter; which can be returned to the hives.

(Signed,)

Approved of group of Judges.

$$
\text { [5 names.] }
$$




\section{CALEDONIAN APIARIAN SOCIETY.}

The head-quarters of this Society are at Glasgow; and, taking example from the British Bee Keepers' Association, shows are held and prizes given for beehives and their produce; also living bees at work in glass hives are exhibited. In addition to which, manipulations connected with bee economy, such as transferring, handling bees in bar-frame and other hives, are demonstrated to beholders.

The exhibition of this year (1877) was held at Edinburgh, in connection with the annual gathering of the Highland and Agricultural Society, and which was very successful.

There was a separate charge for admission to the bee and honey repartment, which was visited by great numbers of people. In consequence of the poor honey harvest, but a small quantity of honey-comb was sent for competition.

With other beehive makers, we exhibited a large collection of our hives, also living bees, with all the appliances needed in bee-culture. The first prize was awarded us for the best and largest display. This prize consists of a handsome silver cup and 40 s.

Amongst our interesting collection were a dozen or so of Italian Alp queens in small boxes, each within a separate box, with a few worker bees. These had been sent over expressly for this show, and would therefore take no harm by being kept a few days, until purchased by some of the enterprising Scotch bee-keepers, and substituted for ordinary queens in the manner explained in the body of this work.

One of the transparent single-comb hives brought from the neighbourhood of Glasgow and exhibited by the indefatigable honorary secretary of the Society, Mr. Bennett, was thought to possess no queen, as no brood was to be seen, and there were so many drones present in the hive. In order to supply what we considered the deficiency, we appropriated one of the boxes containing a foreign queen, and in the 


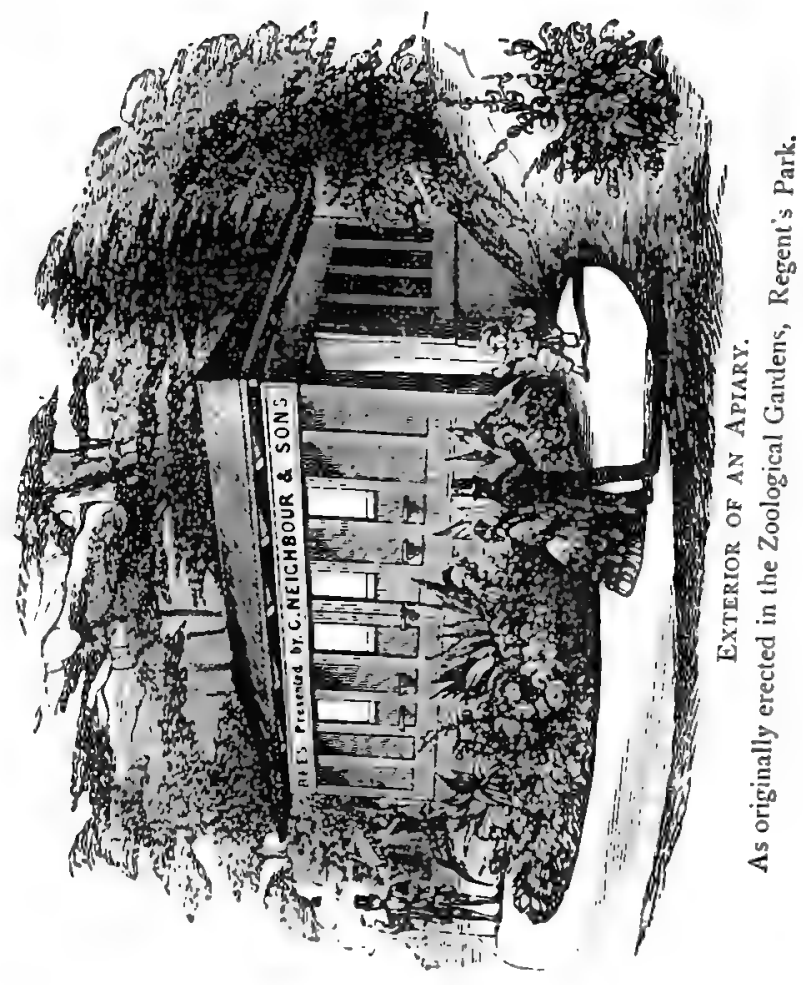




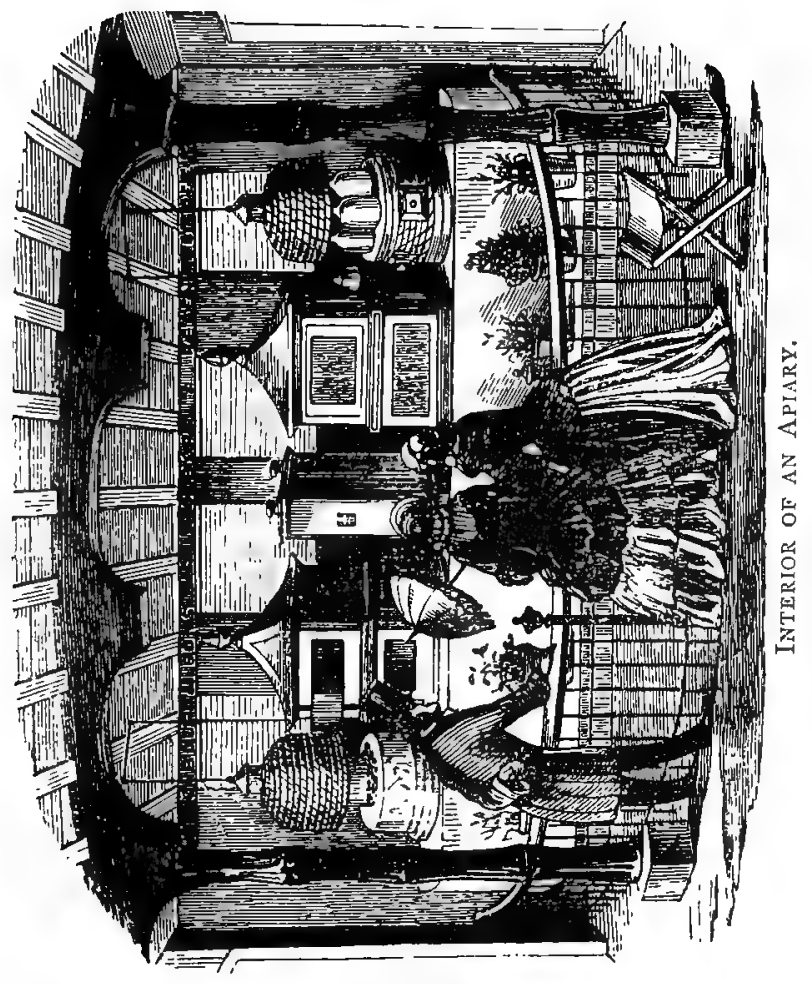


evening allowed her majesty quietly to pass into the hive through an opening on top, taking the precaution to cover up the hive.

On making an inspection next morning we were surprised to find a very dark Italian queen, as we thought. A few hours later we witnessed an interesting scene, no less than a single combat between the real Italian queen and the queen of the hive; for although we had judged the hive to be queenless there was one in the hive all the time, but she was a virgin. At the moment of our observation the two queens were engaged in mortal conflict, and we were able to summon our worthy secretary and a few apiarian friends to witness the battle. After some few minutes (each being curled round against the other) the English or rather the Scotch queen dropped dead to the bottom of the hive and was seen no more. It would have been interesting to have gained possession of the dead queen for examination under the microscope, but the construction of the hive and the position it was in did not allow of searching for her. The Italian mother, who was for some time after greatly excited and evidently much discomposed, reigned supreme, the monarch of the hive; and being already fertilised, the worker bees paid her due attention, but began worrying and tormenting the drones, because they were now not wanted.

These assaults of the little active working bees on the burley drones very much interested the spectators. The queen proceeded with her duties of egg-Jaying, and the bees having exit through the hording the usual work of the hives was carried on fully exposed to view. Not the least gratifying feature was the sight of these little labourers travelling in and out under the glazed covered way.

More active manipulation, such as driving bees from one hive to another, gaining possession of the queen, and exhibiting her in the hand, was carried on in another portion of the shed, and became a source of wonderment to spectators.

Many of the local newspapers had paragraphs descriptive of this new exhibition in comnection with a Scotch argricultural show. 


\section{N D E X.}

Aввот, C. N., Frame-hives, I 46 Abdomen of bees, Ioz

Accident at Stafford House, I64

Acclimatising Bees (Appendix), 349

Advice by Butler, 333

American Bee Journal, Igo

Anatomy of bees, Plates I. and II., facing pages 34 and 86

Anecdote from Butler, 336

", of French clergyman, 334

". showing provision made for swarming, $7^{8}$

Antennæe of bees, 94

Apiary, Geo. Neighbour \& Sons, (frontispiece)

description of, $33^{\circ}$

Applying supers, 264

Artificial swarming, 233

Asiatic bees, 49

Austrian ditto (Lower), 46

BAR-FRAME holder, I92

Bar Supers, I83

Bath and West of England Agricultural Association, 42

Bee as añ insect, 7

" dress, 208

", feeders, Nutt's, I26

" " bottle, 203

" " can, 204,

" " round, 205; wood, 206

", houses, 166-I79.

", traps, 2OI

") veil, 2 IO
Beehives, various, I08 to 165

Bee-keeping in London, 322

"Z Zoological Gardens, 328

"Horticultural Gardens, 329

" St. John's Wood, 329

, Hampstead, $33^{\circ}$

Bees, do they go to sleep? $3 I$

" increase of, 82

", head of, 88

" eye of, 90

" mouth, 9 I

" tongue, 92

" mandibles, 93

", sense of hearing, 95

1" smell, 96

", antennæ, 96

", thorax and organs of motion, 97

", breathing, Ioo

11 stomach, roz

", honey bag, I02

", produce of wax, ro3

" sting, IO4

II dislike to hive, 221

," enemies of, 3r5

,t profitably kept, 336

Bell glasses, see glasses

Berlepsch, Baron von, 4, 6, 10, 36, $42,49,75,2$ II

, theory of drone-breeding, 69

", on swarming, 77

"breeding superfluous princesses, $8 \mathrm{I}$

Bevan, Dr, 3, I8, 66, 
Black Bees, 7I

Book-keeping recommended, $33^{2}$ Box Fumigator, 206

British Bee-keepers' Association, 6,48

\section{CALEDONIAN Apiarian Society} (Appendix), 354

Carbolic acid, use of, 208, 220, 305

Carniolan bees, $45,46,53,78$

Change of frame-hives beneficial in spring, 225

Cheshire's (F.) frame-hive, I45

\section{, nucleus hive 197}

, transferring board, I92

, wax guide-maker, I9I

Comb-building in supers, $33^{8}$

, fixing in ditto, 262

"foundations (American), Igo

Combs, placing in frame-hives, 223

Common cottager's hive, Io 8

Corri, Herr, 47, $7^{8}$

Cottage hive, improved, I I4

Cottager's hive, IIo

,f improved ditto, II2

" improved frame-hive, I42

Cotton, Kev, W. C., 5, 45, 78

Covers, zinc, for hives, I7T, I72

" wood, I72, I74, I75, I77, I79

Cowan's (Mr.) plan of working frame-hives, 255

Crystal Palace skep, Io9

Cyprian bees, 47

DARWIN, Dr. 56, 57

Dathe, 53

" plan of fertilizing queens with Italian drones, 253

Diseases of bees, 306

Dönhoff, Dr. 5, 65, 96

Driving, 226

best condition for, 228

" useful for taking honey,229

Drone bee, I9, 62

$$
\begin{gathered}
\text { " has no father, } 64 \\
\text { eggs, theory of production, } \\
62,252 \\
\text { trap, } 201 \\
\text { comb, to be used sparingly, } \\
224
\end{gathered}
$$

Drone comb, building of, sometimes to be avoided, 238

Dummy frame, I40, I 43

Dzierzon, Dr., 4, 10, 36, 42, 44

, description of the round of the bees' concerns, 32

on swarming, 77
$" \quad$ not a smoker, 210

EGG-LAYING, Io, 67

Eggs and transformations, 59

Ekes, description of, 186

Epitaph on brimstoned bees, 85

Evans (Dr.) poem on bees, 3, quotations from, $59,75,76$, I07, 165

Extracting honey from comb, 274

Extractor, honey, I93

Eyes of bees, 89

FACUlTiEs, and functions, 54

Feeder, Nutt's, I 26

Feeciers, (various), 202

Feeding, 279

Fertile workers, 62, 67

Fittings and apparatus (outside), I66

Flat-topped glasses, I 82

Foul brood, 307

I_angstroth, Woodbury, and Dzierzon on, 308, $3 \mathrm{I} 2$

Fox, Mr. George, 278

" Mr. S. Bevan, 278, 332

Frame-hive, putting swarm into,2rg

$$
\begin{aligned}
& \text { facility for placing } \\
& \text { combs, 223, } \\
& \text { with cover and stand, } \\
& \text { x75, } x 77, \text { I79 }
\end{aligned}
$$

Frames, removing, 268

French exhibition, 165

Fumigators, 206

Fumigating, description of, $23 \mathrm{r}$

GENERAL hints on frame-hives, 254

Gerstäcker, 54

$$
\text { remarks, } 332
$$

Glass hives, ladies' observatory, r2o

$$
\begin{aligned}
& . \quad \text { frame, I38 } \\
& \text { with cover and super, } \\
& 177,178
\end{aligned}
$$

Glasses for supers, I80, I8I, 182 
Guide comb, $188,26 \mathrm{r}-2 \epsilon_{4}$ description of, IgI

HAWkins, Mr. Waterhouse, 5o

Head of bee, 88

Hearing of bees, 95

Heath bees, 46

Hints, general, on frame-hives, 254

Hives, modern, I08 to I65 $"$ sometimes destroyed by entrance being stopped, 343

Hiving swarms, 212

Honey bag of bees, I02

" cutters, 193

" description of, 296

", extractor, I93

, test when adulterated, 297

Houses for hives, 166

Hruschka, Von, I93

Huber, 62

Hunter's, Mr., support for hive when driving, 229

IMPRESSED wax sheets, I87

Improved cottage hive, II3

, cottager's hive, III

, ditto, no windows, II9

Increase of bees, 82

Insects necessary for existence of flowers, 59

Italian bee, 34, 35, 4I

Italianising hives, $25 \mathrm{I}$

KERNER, $5^{8}$

Kleine, Herr, 5, 35, 244

Klipstein, Von, anecdotes of queens, 22, 66

Knowledge of bee-keeping necessary for a gardener, 343

LADIES' Observatory Hive, I 20

Lanarkshire bee-keeper, 297

Lanarkshire hive, I55

Langstroth, Rev. L. L., 3, 5, ro, $43,83,85,129,346$

Langstroth, Rev. L. L., on transferring swarms, 220

Lee's supers, I45, I46

Legs of bees, $9^{8}$
Leukart, Professor, 64, 65

Ligurian bee, 7,34

Lon'don apiaries, 325

Lower Austrian bees, 46

Lubbuck, Sir John, 6, 57, 59

MAHAN, Mr., 9

Mandibles of bees, $9 \mathrm{I}$

Manipulation with bees, $2 \mathrm{I} 2$

Mel-extractor, "196

Melting down combs, 275

Mouth of bees, 9 I

Munn, Major, I29

NADIRS, description of, I86

Neighbours' improved cottager's hive, $\mathrm{Ir}_{3}$

Neighbours'improved cottagehive, II 4

Neighbours' new frame-hive, 139

New cover and stand for framehives, I75, I76, I79

New wood feeder, 206

Nucleus hive, 197

Nutt's hive, 123

ORCHARD, good place for an apiary, 56

Organs of sensation, 88

," motion, 97

", reproduction, 62

Parthenogenesis, 64

Pasturage for bees, 293

Payne's (I. H.) glass, I82

Perforated zinc adapter, I4I, I43, I44, 200

Philadelphia Exhibition, 160; and Appendix, $35^{\circ}$

Philadelphia hive, 143

Pollen basket, 98

,"' preservation from incursions of ants, $5^{8}$

deseription of, 298

", substitute for, 299

Position of hives, 292

Propolis, 300

QUEFN, 8 
Queen, power of egg-laying, ro

, homage paid to fertile, 12

, no attention bestowed on virgins, 13

two queens in a hive, 15

" sting of used for depositing eggs, 15

some queens will not fight, ${ }_{5}$

consternation at loss of, 16

life of, $I 9$

fertilisation of, $\mathbf{I T}, 20,22$,

24

in relation to sexes, 63

at swarming time, 73

and drone preventers, 200

rearing, $17,27,77,243$

cells, 17,244

securing, 228,240

introducing stranger, 247

Quilts, r80

cages, Ig8, 244

RATIONAIE of swarming, 72

Relation of sex to cells, 67

Removing bees, 259 plants to insects, 56,57

," supers, 266

,, frames, 268

Reproductive economy, 62

Renfrewshire bee-keeper,24,4I, I 54 . queen cage, I99

, instructions on su-

Robbing, 225, 305 pering, 337

Rorl's (Mr.) way to get quit of fertile workers, 67

Round feeder, 205

Royal cells, $17,2+4$

.' ', transferring, I98

, duels, I5, and Appendix

S.tLT obtained by bees, 3o, 97 Samuelson's work, The Honey Bee, 5, 9I, 96

Sieloold, Von,on Parthenogenesis, 64 Skep, Crystal Palace, rog

, (old), transferring combs from, 223
Slow feeding; 204

Smelling, sense of, largely possessed by bees, 96

Smith, Mr. J., 48

Smyrnæan bees, 47

Society of Arts, 57

Stands for hives, II8, I70

Stewarton hive, I46 to I55, 337

Sting, ro4

," prevention and cure, 286

Stocks (old) transferring, 222

Stomach of bees, roz

Straw frame-hive, 136, I4I

hives, round, ro8 to 120

Stupefying bees, 207

Supers, I80, I8I, I82, $18_{3}, \mathrm{I} 84, \mathrm{I} 8_{5}$

Superstitions about bees, $34 \mathrm{I}$

Supplying natural comb, 26r

Swammerdam, 63

Swarm, number of bees composing, 79

"second flight disastrous, $2 \mathrm{I} 4$

often mix, 214

taking, $2 \mathrm{r}_{4}$

sending to a distance, $2 \mathrm{I} 7$

conveyance of, 217

transferring, 2 I 8

returning, $2 \mathrm{x} 8$

brought from a distance, 219

should be fed, $22 \mathrm{I}$

truant, $7^{8}, 3^{\mathrm{r}} 7$

artificial, 233

Swarming, rationale of, 72

provision made for, 74,
$7^{8}$
signs of, 80
a provision of Nature.
2 I2

'TAYLOR, the late Mr. H., 37

Taylor's glasses, $18 \mathrm{I}$

Thorax of bee, 97

Tongue of bee, 92

Transferring board, I92

$$
" \quad \text { swarms, } 2 \text { I8 }
$$

"old stocks, 222

Tristram, Rev. H. B., extract from his book, 5 工 
Tube fumigator, 207

UNICOMB observatory hive, outdoor, 157

Unicomb observatory hive, directions for, I60

Unicomb observatory hive, indoor, I 62

Uniting weak colonies, 229

VENTILATION performed by bees, 3०, 285

Ventilators, 124

Vulcanite for feeding-stage, 203

WASPS, 3I5 sivarm, 77

Water for bees, 30,33 I

Wax, how produced, I03

"impressed sheets of, 187

"secretion of, 302
Weighing hives, 276

Wildman's bees, 322

Wings for bees, 97

Winter precautions, 283

Wood cover, I72

"feeder, 206

Woodbury, T. W., 37, 42, 49, 50

$" \quad$ frame-hive, I $_{34}$

" mode of hiving swarm, 216

" mode of transferring swarm, 220

2) hive cover, $\mathrm{I} 74$

XENOPHON's army poisoned with honey, 298

ZINC covers, ornamental, I7I

$"$ " plain, I72

"rests, I4O

" adapters, perforated, I4I, I $43, \mathrm{I} 44,200$

Hazell, Watson, and Viney, Printers, London and Aylestury. 



\section{PRICE LIST}

\section{OF \\ NEIGHBOUR \& SONS' \\ IMPROVED BEE-HIVES}

For taking Honey without the Destruction

of the Bees.

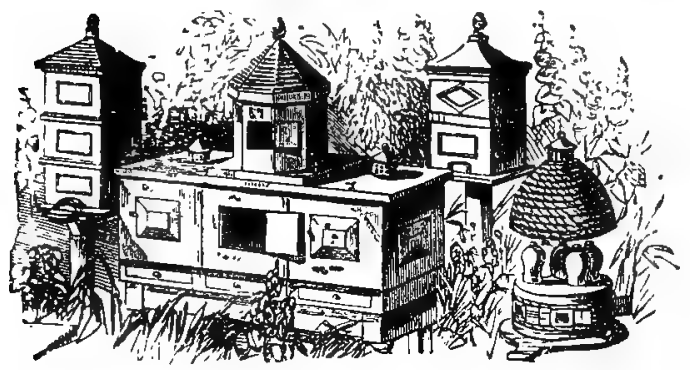

EXHIBITORS AT THE

Great Exhibition, 1851. Dublin Exhibition, 1853.

Exposition Universelle, 1855.

International Exhibition, 1862. Dublin Exhibition, 1866

Paris Exposition Universelle, 1867.

Annual International Exhibition, 1873.

British Bee-Keepers' Shows, Crystal Palace, 1874, 1875.

Alezandra Palace, 1876.

International Philadelphia Exhibition, 1876.

Caledonian Apiarian Show at Edinburgh, 1877. 


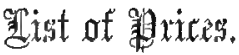

No.

I. Nutt's Collateral Bee-Hive

Stand for ditto

2. Single Box Hive .

3. Neighbours' New Frame Stock Hive Super

Cover for ditto

4. Carr's Bar and Frame Hive

Super for ditto

5. Neighbours' Improved Cottrage Hive

Stand for ditto

6. 1)itto, without Windows

7. Ladies' Observatory Hive

8. 'The Cottager's Hive.

9 and Io. Bee Feeders.

II and I2. Fumigators

13. Honey Cutters

4. Improved Cottager's Hive

I5. Honey Extractor for hand use .

I6. Woodbury Bar Super .

I7. Neighbours' New Supers, Wood and Glass

each 5 s. and

E s. $d$.

- 550

- o r6 o

- 330

50

$\begin{array}{lll}1 & 5 & 0\end{array}$

27 s. and 200

I9 6

I9 6

I5 0

I0 6

50

50

I0 6

Ditto ditto Straw and Wood

r8. Taylor's Glass, to contain about 8 ib.

I9. Payne's Glass, with hole in centre, to afford additional space to supers partly filled .

20. Neighbours' Revolving Indoor Unicomb Hive 030

2I. New Can Feeder, on the principle of a fountain, adapted for slow, stimulating feeding ( 3 pints)

22. New Frame Stand, to be used when manipulating with movable combs

23. American Sectional Supers - * o 56

24. Taylor's Super Glass

25. Bell Glass, to contain about $9 \mathrm{lb}$ :

26. Ditto ditto $5 \mathrm{lb}$ : : :

27. New Shape Flat-top Glass, with lid to place on table inverted

30. Shallow Glasses, $9 \frac{1}{2}$ in. wide by 4 in.-deep

3I. Bee Dress, with Sleeves (post free, 3d,"extra) : :

32. India-rubber Gloves (by post, 2d. extra) per parr :

33. Common Straw Hives

34. Small Straw Super Hives

36. Floor Boards, according to description, 2s., 2s. $6 \mathrm{~d}$.

37. Zinc Cover for Improved Cottage Hive o 3

38. Ornamental Zinc Cover

39. Bee House, to contain two Improver Cottag' $\begin{array}{lll}2 & 2 & 0\end{array}$ 


\section{LIST OF PRICES.}

No.

42. Woodbury Bar and Frame Hive

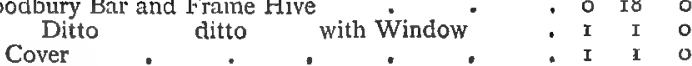
Stand

44. The Bottle Feeder : $\quad: \quad \begin{array}{ccc}0 & 2\end{array}$

45. Woodbury Straw Bar and Frame Hive, 18s. 6d. and 12

46. Outdoor Unicomb Hive, to take Woodbury Frames 5 ro o Stand

47. Common Cotrage Hive, 5s. 6d. each.

49. Glass Frame Hive

5I. Improved Wax Sheets

52. Lee's Octagon Straw Hive Super Cover and Stand

53. Lee's Octagon Hive, in Mahoghany . • . o 176

54. Ditto ditto Pine . . . 060

55. Ditto ditto Glass Sides . . . 090

56. Ditto ditto smaller, in Mahoghany 0 r2 6

57. Ditto ditto Wooden Sides, Glass Top . o 56

58. Stewarton Hive (3 Stock Boxes, I Honey Box) . I I 0

59. New Wood Bee Feeder . . . 050

6o. Neighbours' Cottage Frame Hive • . 0776

6r. Neighbours' Divisional SUPer, 35. 6d. per pair 006

62. Cover for Neighbours' Frame Hive . . . o 86

63. Cottage Frame Hive, Woodbury Frames : : 076

64. Cheshire's Frame Hive, complete-Stand, Stiper, and Cover, the latter painted . . ? . I 176

65. Abbott's ditto ditto . . . . . . I 176

66. Lanarkshire Stock Hive , . o I6 6 Super . . . . . . $\quad 0 \quad 66$ Roof : . . 070

67. Neighbours' New Bee Veil (by post, 2d. extra) $\quad$. $0 \begin{array}{lll}0 & 2\end{array}$

68. Flat-top Glass with 3 inch hole in centre (similar to Payne's), for adding space to Supers

69. Same construction as above, $6 \frac{1}{2}$ in. wide, 3 in. deep - 036

70. Lee's Double Super . per pair

71. Cheshire's Nucleus Hive, for Queen Rearing . $\quad$. $0 \begin{array}{rlr} & 5 & 6\end{array}$

72. Cheshire's Transferring Board . . . . o 10 6

73. Cheshire's Prize Smoker , , , , 020

74. Cheshire's Drone Trap. . . . . 046

75. Syrup Can and Shovel : $: \quad \vdots \quad \vdots 0066$

76. Vulcanite Feeding Plates $:$ each $6 \mathrm{~d}$, and 0 - 0

77. Bligh Bee Quieter

(Less by the dozen)

79. Crystal Palace Skep . $\quad: \quad$ Is, and 0 . Floor Board Super

8o. Neighbours' Straw Frame Hive, with New-shaped Cover and Stand, grained and varnished 


\section{LIST OF PRICES.}

No.

8x. New Cottage Frame Stock Hive, with Window

$£$ s. $d$.

82. NEw Cover and Stand for the above (painted) , I 7 o

83. Neighbours' Cylindrical Honey Extractor . . 2 io o Two Wire Cases . . . . . ० I2

84. Bee House for One Hive . . . 2 to 0

85. Renfrewshire Stewarton Movable Comb Hive, consisting of 3 Stock Boxes and I Honey Box .

86. Bee Traps, for clearing Bees from Supers . $\quad$. 0236

87. Philadelphia Hive, with Super, Stand, and Cover. 23 a

88. Sectional Supers . . the set o + 6

89. New Cover for Cottage Frame Hive (carries its own Stand) .

9o. Quinby Smoker: $: \quad: \quad$ : $\quad$ : 076

\section{PUBLICATIONS ON BEES.}

"The Apiary;" or, Bees, Beenives, And Bee Culture,

by Alfred Nejghbour.

Hive and Honey Bee, by Rev. L. L. Langstroth (American).

A New Edition

Quinby's Bee-Keeping (American)

Italian Alp Bee, by Hermann

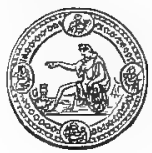

PRIZE MEDALS AWARDED AT THE PHILADELPHIA AND OTHER EXHIBITIONS.

\section{GEO. NEIGHBOUR \& SONS'}

PRICE CURRENT OF

\section{(Gamine \\ agtaliarr

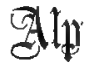

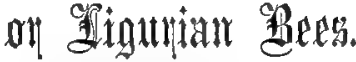

AN ITALIAN QUEEN in a small Box, accompanied by a faw Worker Bees, with full directions for uniting to English Stocks, each from April and May, I2s. ; June, IIs. ; July, ros. ; August, 9s. ; September, 8s. ; October, 7s.

Orders should be given in advance.

For parcels of Sij Queens at one time, Is, each less,

A STOCK, with genuine Italian Queen, packed so as to travel by rail with comparatively no risk of damage, including the Sir.zw Frame Hive with window, $f_{4}$; or if in New' Cheap Frame Hive, No. Co or 63 , which has no window, $f 355$.

Sivarms and Stocks of English Bees can be obtained. 





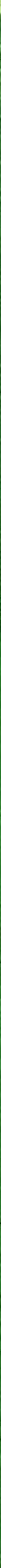

